Deaf Education, the Politics of Humanitarianism, and State Formation in Saskatchewan and Alberta, 1880-1931

by

\title{
Sandy Barron
}

A thesis submitted to the Faculty of Graduate and Postdoctoral Affairs in partial fulfillment of the requirements for the degree of

\author{
Doctor of Philosophy \\ in \\ History \\ Carleton University \\ Ottawa, Ontario
}

(C) 2021

Sandy Barron 


\begin{abstract}
This study traces the development of deaf education in Alberta and Saskatchewan between 1880 and 1931 and its corresponding effects on state formation in Western Canada. Through this topic, it identifies a rise of deaf politics in the wake of the First World War that achieved notable successes in Saskatchewan in the interwar period. A new term for discussing oppressive attitudes against deaf communities from hearing people, humanitarianism, is proposed and explored. These provinces took decades to develop state institutions that were meant to ensure "productive" and "independent" futures for deaf children in the burgeoning nineteenth-century liberal colonial order on the Prairies. In doing so, they began to define their own provincial boundaries, both in the sense of geography and responsibility. They also began to define theoretical boundaries between deafness and hearing, intellectual ability and disability, as well as rights and humanitarian assistance. The development of deaf education in Alberta and Saskatchewan, I argue, pushed emergent provinces to accept the rights of deaf youth to education, though this process was uneven and did not represent a straight teleological arch. Deaf associations and individuals themselves pushed the provinces and took leadership roles in this process, making them heretofore unrecognized political agents in search of rights. Chapters include considerations of deaf education as an instrument of settler colonialism, histories of hearing and deaf families with deaf children, the role played by the Manitoba School for the Deaf in marking intellectual disability in the three Prairie provinces, and the role of the Western Canadian Association of the Deaf in the founding of the Saskatchewan School for the Deaf in 1931.
\end{abstract}




\section{Acknowledgements}

This project began as an extension of my career in formative education, at an educational clinic in Calgary, Alberta. Working with, and planning programs for, so many different kids and youth fostered my interest in educational accommodation. A brief foray into a project about the Simplified Spelling movement led, thankfully, to my discovery of Issue \#1 of Silent Echo in a class entitled The Practice of History at the University of Calgary. Between 2013 and 2014, several professors at the university pushed me to go after my goal of attaining a History $\mathrm{PhD}$ through a study of the Manitoba School for the Deaf for my MA thesis. R. Douglas Francis, David Marshall, Jewel Spangler, Ken MacMillan, and Nancy Janovicek all encouraged my work and helped me focus my efforts from my time as a returning student in 2012 to the completion of my MA thesis in 2016. Several of my fellow MA students, especially Shawn Brackett and Kesia Kvill, remain colleagues and friends.

I came to Carleton in 2016 to work with Dominique Marshall, with the knowledge that a network of interdisciplinary disability scholars worked there. I quickly fell in with Kristin Snoddon, Roy Hanes, Adrian Chan, and Beth Robertson through the Carleton University Disability Research Group and the Disability Studies Minor Committee. Pat Gentile, John C. Walsh, James Miller, Norman Hillmer, James Opp, Danielle Kinsey, Laura Madokoro, and other faculty members at Carleton have, at various times, helped me keep going with encouragement and advice throughout my four years here. Joan White, the History Department's Graduate Administrator, has been essential to my progress through the program, and has been wonderful while doing it. Special thanks to Danielle Kinsey and James Opp for both serving on my committee and helping to shape 
this project through their criticism and feedback. I also wish to thank the external examiner on my committee, Dr. Joseph J. Murray at Gallaudet University in Washington, D.C., for his time, attention, and helpful comments. Finally, I wish to thank Dr. Kelly Fritsch, my internal-external examiner, and ASL interpreters Amy Cook and Melissa Cyr. My PhD cohort, defined widely to include students from four different starting points, was essential to my success and survival in the program. Breanna Lester, Jacqueline Di Bartolomeo, Helen Kennedy, Rick Duthie, and Tyla Betke have been sounding boards and supportive friends. I have leaned on them all throughout my years at Carleton, and I'm sure the load was heavy at times, especially during a Trump Administration and global pandemic (for which we all deserve two campaign medals). Though not in my PhD cohort, Hollis Pierce has become a great friend in my adoptive city. An inspiring scholar, a committed Guinness drinker, and a long-suffering Oilers fan, Hollis helped me through these years more than he knows. No one who knows him would be surprised by that, and I am far from the only person who can say that.

My supervisors have been essential to this project. Dominique Marshall's mixture of trust in my judgement and modelling what it means to work like a scholar were essential to this project. Her insistence that I take some time to "get lost" in my field before honing in on my project was a good roadmap for what I could expect a $\mathrm{PhD}$ program to look like. Dr. Marshall, above all, takes concerted work in the interest of others, supports and highlights the ideas of those around her, and served the Department as chair for several consecutive terms. She gives a lot to those on the fourth floor of Paterson Hall, and stands in contrast to the stereotype of the inward-gazing, selfconcerned ivory (concrete?) tower scholar. Much of what is interesting and good in this 
study is due to her inspiration and encouragement, either through questioning and criticism or through drawing attention to where what I was saying was important. My propensity for hackneyed, over-manicured metaphors was often tamed by Dr. Marshall, but sometimes left fallow. All hackneyed metaphors within remain my responsibility.

Kristin Snoddon has also been very important to this project. Though an applied linguist, Dr. Snoddon's interest in the history of her communities kept me tethered to both the Deaf Studies literature and the possibilities and limits of a project dependent upon a sketchy archival record that was assembled and maintained by several provinces without deaf interpretation and involvement. I thank her for staying involved with my project after her move from Carleton to Ryerson University. She was also very supportive and positive when I made mistakes in my writing and conduct (and signs), and has been very helpful as I think about what lies ahead for me in a professional sense.

My $\mathrm{PhD}$ program also tracked the peaks and valleys of periodic crises in my mental health. My wife Sonia, friends, professors, and supervisors were supportive and understanding when I needed it. I was far from alone in experiencing a mental health crisis in my $\mathrm{PhD}$ program, and mental health issues remain an epidemic in academic programs across the country. While I (and others) clashed with the Grad Studies Committee at times, my department gave me space and support when I needed to step away and recharge. For a person with a history of major depressive episodes, I chose well with a small, supportive department. Bre, Helen, Tyla, and Hollis did some heavy lifting from 2018-2020 as well. Thanks guys.

Aside from Kristin Snoddon, several deaf community members across the country have inspired and supported me throughout the years that have culminated in this 
dissertation. Len Mitchell and Jonathan Miller at the Manitoba School for the Deaf in Winnipeg welcomed me in 2014 and allowed me access to the Deaf Heritage Room at the school. Educator Joanne Weber of Regina has been supportive and interested in the project, and I hope that some of the video-interview work we broadly outlined can still happen in Saskatchewan in the future. My deaf ASL instructors at Carleton have been interested and supportive of my project as well, especially Denise DeShaw and Cynthia Benoit. Hearing archivists Tim Novak at the Provincial Archives of Saskatchewan and Chris Kotecki at the Provincial Archives of Manitoba have also been of invaluable help for a researcher learning the ropes on the fly.

My family in Nova Scotia and British Columbia also deserve thanks and acknowledgements. My brothers Matthew and Stephen have taken interest in my work and given me academic and life advice for years. My mother, Carol, has been supportive and has celebrated my successes and supported me in my tough spots. I think every day about my father, Bill, who likely did not foresee me returning to school at the time of his death eleven years ago, but would have really enjoyed tracing my progress. I miss him all of the time, but especially wish that I could run ideas by him and get his take on my theoretical stabs in the dark. A forester by training, he always told us that one can only gauge the health of the forest by "looking down, not up," a maxim that has stuck with me in several contexts. My father and mother-in-law, Hiroshi and Yukiko Okamoto, have taken interest, helped to hold me up, and celebrated with me.

Sonia Okamoto has been with me for this entire foray into academic life. While we married in 2016 shortly before moving to Ottawa, we have been together since 2007, and she has been my partner through the ups and downs of the past thirteen years. Thanks 
to her for her support, love, and critical ear. A PhD program is hard on a marriage, and ours was no exception. Thank you, Sonia, always. 


\section{Table of Contents}

$\begin{array}{lll}\text { Abstract } & \text { ii }\end{array}$

$\begin{array}{ll}\text { Acknowledgements } & \text { iii }\end{array}$

Table of Contents viii

List of Tables $\quad$ xi

List of Illustrations $\quad$ xii

Table of Appendices $\quad$ xiii

Table of Abbreviations $\quad$ xiv

Chapter One: Introduction to Humanitarianism and the Crystallizations of State Power

1.1 Introduction 1

1.2 Study Parameters 4

1.3 State Formation: Theory and Practice $\quad 7$

$\begin{array}{ll}1.4 \text { Prairie Canada as Borderland } & 15\end{array}$

1.5 Deaf/Disability History - Considerations and Cautions 17

1.6 More Theoretical Underpinnings and Discussion: Humanitarianism, Rights, and Futurity $\quad 24$

1.7 Rights: Grounding the Term in Western Canadian Deaf History 36

1.8 Deaf Chronicle: A Broad Overview of Popular American Deaf History 38

1.9 Overview of Structure 42

\section{Chapter Two: Positionality, Process, and Misgivings}

2.1 Introduction 44

2.2 Positionality $\quad 45$

2.3 Disability Studies and Human Diversity 49

2.4 Sources and Methodology 56

$\begin{array}{ll}2.5 \text { Privileges and Choices } & 62\end{array}$

2.6 Key Contributions of this Study 65

$\begin{array}{ll}2.7 \text { Conclusion } & 71\end{array}$ 
Chapter Three: Early Deaf Education, Settler Colonialism, and the Establishment of Western Canadian Internal Borders, 1890-1905

$\begin{array}{ll}3.1 \text { Introduction } & 73\end{array}$

3.2 Liberalism, Colonialism, and Deaf Education $\quad 75$

3.3 Indigenous Sign Languages on the Prairies 82

3.4 The Groom Expedition, Deaf Immigrants, and Partisan Print $\quad 87$

3.5 The Founding of the Manitoba Institute for the Deaf and Dumb, 1888-9 94

3.6 The "Further West Deaf' and Intergovernmental Struggle, 1893-1899 100

3.7 Indigenous Students and the MIDD/MSD, 1890-1925 110

3.8 The Move Toward Provincehood, 1899-1905 115

$\begin{array}{ll}3.9 \text { Conclusion } & 117\end{array}$

Chapter Four: "Mingled Joy and Pain": Deaf Children in Hearing Families, 18941931

$\begin{array}{lr}4.1 \text { Introduction } & 120\end{array}$

4.2 Bureaus of Child Protection and Compulsory Schooling 123

4.3 Deaf Children in Hearing Families: Labour and Poverty 128

4.4 Hearing Parents, Deaf Education, and Liberal Futurity 133

4.5 Medical Care and Death at Home and the Manitoba School for the $\begin{array}{ll}\text { Deaf } & 147\end{array}$

4.6 Calling Upon the Doctor, Calling Upon the Government 157

$\begin{array}{ll}4.7 \text { Conclusion } & 166\end{array}$

Chapter Five: "The Great Scramble of Men": Deaf Children in Deaf Families and the Emergence of a Western Canadian Deaf Community

$\begin{array}{ll}5.1 \text { Introduction } & 168\end{array}$

5.2 Deaf Families Through Local and Regional Lenses 171

5.3 Emerging Deaf Communities and (Silent) Echo, 1900-1920 181

5.4 The Western Canadian Association of the Deaf's Early Initiatives, 1920-1933 190

5.5 Gallaudet College and Prairie Canada 203

5.6 Rights Rhetoric: Transnational Deaf Currents 206

5.7 American Sign Language: Transnational Deaf Currents 215

$\begin{array}{ll}5.8 \text { Conclusion } & 217\end{array}$ 
Chapter Six: Constructing Intellectual Disability at the Manitoba School for the Deaf, 1890-1920

6.1 Introduction 219

6.2 Duncan McDermid and the Making of a Superintendent's Authority

6.3 Eugenics and Hardening Constructions of "Feeble-Mindedness."

6.4 Doctor Howard McDermid

6.5 "Disabled and Deaf" and "Hearing and Non-Verbal" Applicants from Alberta and Saskatchewan

6.6 Constructions of "Feeble-Mindedness," Constructions of Ideal

Deafness

6.7 Compulsory Schooling on the Prairies and Intellectual Disability 247

6.8 Conclusion

Chapter Seven: Toward Another Saskatchewan School for the Deaf: The Western Canadian Association of the Deaf, Progressivism, and Transformations in Humanitarian Thinking, 1921-1931

7.1 Introduction

7.2 Progressivism and Saskatchewan Politics

7.3 Imagining the Saskatchewan School for the Deaf, 1927-1929

7.4 The Rhetorical Power of State-Building: R.J.D. Williams'

Correspondence with Parents

7.5 The Sociological Tour: The Spring 1929 Reports 274

7.6 Historiographical Considerations

7.7 Saskatchewan Politics and the 1929 Election

7.8 The Depression: Repurposing Federal Dollars for Provincial Fiscal

Stimulus

7.9 Conclusion

\section{Chapter Eight: Conclusions}

8.1 Introduction

8.2 Contributions of this Study

8.3 Connections to the Present and Conclusions 


\section{List of Tables}

4.2 Evolution of the Number of Applicants from SK and AB to the MSD, 1894-1931

4.3 Trends in Non-Household Member Application Filers by Occupation 


\section{List of Illustrations}

4.1 Students from Alberta, The Echo

5.1 "A Few of Winnipeg's Deaf Residents, 21 Years Ago"

7.1 R.J.D. Williams at the Future Site of the SSD, Saskatoon, Sask, 1930

8.1 Group Portrait, 1932 WCAD Convention 


\section{List of Appendices}

Appendix 1: Application designed by Duncan McDermid (1901)

Appendix 2: Application designed by Howard McDermid (1917)

333 


\section{List of Abbreviations}

$\begin{array}{ll}\text { ASD } & \text { Alberta School for the Deaf } \\ \text { ASL } & \text { American Sign Language } \\ \text { BCP } & \text { Bureau of Child Protection } \\ \text { BSL } & \text { British Sign Language } \\ \text { CAD } & \text { Canadian Association of the Deaf } \\ \text { FIPPA } & \text { Freedom of Information and Protection of Privacy Act (Manitoba) } \\ \text { FSL } & \text { French Sign Language } \\ \text { MIDD } & \text { Manitoba Institute for the Deaf and Dumb (1889-1914) } \\ \text { MSD } & \text { Manitoba School for the Deaf (1914-present) } \\ \text { MVSL } & \text { Martha's Vineyard Sign Language } \\ \text { SGGA } & \text { Saskatchewan Grain Grower's Association } \\ \text { SSD } & \text { Saskatchewan School for the Deaf } \\ \text { WAD } & \text { Winnipeg Association of the Deaf } \\ \text { WCAD } & \text { Western Canadian Association of the Deaf }\end{array}$




\section{Chapter One: Introduction to Humanitarianism and the Crystallizations of State Power}

"Human rights are never in such danger as when their only defenders are political institutions and their officers."1

\section{George Herbert Mead, 1915.}

"Finally I turn to Melissa and my other students: 'I have a Deaf body, you have a Deaf body. There is one hell of a difference between a Deaf body and a hearing body.' I'm desperate to tell them of the other world waiting for them."

Joanne Weber, Saskatchewan deaf educator and author, $2013^{2}$

\subsection{Introduction}

In 1973, senior students at the Saskatchewan School for the Deaf (SSD) walked out of class for two days to protest the school's ban on the use of American Sign Language. Garnering media attention in Saskatoon through pickets and placards that demanded the use of "total communication" methods, these students pressured the Saskatchewan Government to change the school's language policy that year. ${ }^{3}$ The next year, the school hired its first deaf teacher in decades. By 1982, the school was renamed after the man who had led a "committee of one" with the Western Canadian Association of the Deaf(WCAD) to found the school from 1927 to 1931, R.J.D. Williams. The activists who had provoked the transition of the SSD from a resolutely oralist institution that banned sign language to one that used total communication in classrooms by the late

\footnotetext{
${ }^{1}$ George Herbert Mead, Selected Writings, edited by Andrew J. Reck (Chicago: University of Chicago Press, 1964). Quoted in David L. Brunsma, Keri E Iyall Smith, and Brian K. Gran, Handbook of Sociology and Human Rights (Boulder: Paradigm, 2013), 1.

${ }^{2}$ Joanne Weber, The Deaf House (Thistledown Press, 2013), 135.

3 "Total communication" was a combination of oral communication, ASL, and the use of the manual alphabet. It commonly involved simultaneous signing and speaking, and was favoured by deaf critics of oralism in the early 1970s. Johnson et al, Unlocking the Curriculum: Principles for Achieving Access in Deaf Education (Washington, D.C.: Gallaudet Research Institute, 1989), 4.
} 
1970s included members of the WCAD, hearing allies, deaf activists in Manitoba, and allies from the Canadian Association of the Deaf (CAD), especially David Peikoff, a major figure in the school's founding with Williams.

R.J.D. Williams died in 1973, the same year as the student protests. The year before, he had given a sign language address to the teachers at the SSD that needed to be interpreted into spoken English for much of the faculty. Williams had retired in 1963, after three decades of being the only deaf faculty member at the school, where he served as the Supervisor of Students beginning in 1931. Williams, as this study will show, was a prominent member of an earlier generation of young activists that founded the WCAD in the early 1920s and advocated for deaf rights to education, driving, and insurance, while building a durable inter-provincial organization that fought against oralism for decades with mixed results. Like their forebearers, the senior classes at the SSD in the 1970s were part of a generation of deaf and disabled activists throughout the United States and Canada. These later disabled organizers were inspired by the Civil Rights struggles in the United States in the 1950s and 60s. Disability movements in the 1970s, including the Union of Physically Impaired Against Segregation in the United Kingdom, have been academically and popularly represented as the first generation of disabled activists to demand rights and provisions from the state. ${ }^{4}$ Yet the SSD high school seniors also had the existing model of deaf activism undertaken in the 1920s by Williams' generation. The political movement that had successfully pushed for access to deaf education in the $1920 \mathrm{~s}$ may have seemed ineffective and resigned by the 1970s, relying on different languages of protest, purveying a language of deaf community but not yet culture, and pursuing rights

\footnotetext{
${ }^{4}$ See Dustin Galer, Working Towards Equity: Disability Rights Activism and Employment (Toronto: University of Toronto Press, 2018).
} 
through a politics of allyship rather than protest. $^{5}$ It is difficult to ascertain how much this new generation knew of Williams' and Peikoff's generation, and such questions are outside of the purview of this study of the origins and growth of the Williams/Peikoff generation of WCAD activists who pushed hard against the complacency and humanitarian paternalism of hearing people in the early twentieth-century. Certainly the 1970s generation knew Williams personally, as he continued to socialize with SSD students after his retirement. Thus the year 1973 is a good, if oversimplified, point at which to mark the handing-over of deaf leadership from those who sought rights from the state through allyship, and those who advocated a more cultural brand of activism.

This dissertation concerns the role of deaf education in Alberta and Saskatchewan from 1880 to 1931 in provincial state formation. These provinces, I argue, took decades to develop state institutions that were meant to ensure "productive" and "independent" futures for deaf children in the burgeoning nineteenth-century liberal colonial order on the Prairies. In doing so, they began to define their own provincial boundaries, both in the sense of geography and responsibility. They also began to define theoretical boundaries between deafness and hearing, intellectual ability and disability, as well as rights and humanitarian assistance. The development of deaf education in Alberta and Saskatchewan, I argue, pushed emergent provinces to accept the rights of deaf youth to education, though this process was uneven and did not represent a straight teleological arch. Deaf associations and individuals themselves pushed the provinces and took

\footnotetext{
${ }^{5}$ David Peikoff,(1898-1995) a very prominent Canadian deaf activist, was really more of a precursor to this new generation than Williams. Indeed, as we will see, his more "vocal" and insistent form of activism would distance him from others he saw as more moderate, prompting him to leave the WCAD in 1933.
} 
leadership roles in this process, making them heretofore unrecognized political agents in search of rights.

\subsection{Study Parameters}

I have endeavoured to make a contribution to two major fields in this study - the history of a formative period for deaf ${ }^{6}$ people and communities in Canada, and the project of expanding the accepted parameters of "political history" in Canada - what some have dubbed "The New Political History." These contributions are woven together out of necessity and are inexplicable without each other. If the New Political History seeks to serve a vision of political life and power that is influenced by those previously considered to lack political influence, it also serves to expand the identifiable field of topics that have made central contributions to Canadian political history, and render Canadian history in more complexity. ${ }^{7}$ This dissertation tries to weave a project concerning the beginnings of "special education" and the process of both state formation and the expansion of political life in twentieth-century Canada. Catherine Kudlick has called the study of special education a "stagnant backwater," and this study is one of a few in the Canadian context that has tried to re-invigorate the field and place it in a larger national and intellectual context. ${ }^{8}$ This study does suggest the "expansion of political life" and power at times in

\footnotetext{
${ }^{6}$ In this study I will follow the lead of Kusters, de Meulder, and O’Brien in adopting the more inclusive lower-case spelling of "deaf." Recently, scholars had taken to capitalizing "Deaf" when writing about those who claim membership in deaf communities and culture, but this excludes those deaf who do not subscribe to this cultural and political distinction. It is also not shared in transnational deaf contexts. See Annalies Kusters, Maartje de Meulder, and Dai O'Brien, "Innovations in Deaf Studies: Critically Mapping the Field," in Innovations in Deaf Studies: The Role of Deaf Scholars, ed. Annalies Kusters, Maartje de Meulder, and Dai O’Brien (Oxford: Oxford University Press, 2016), 13-14.

${ }^{7}$ Colin Grittner, "Greater Expectations: Politics, the New Political History, and the Structuring of (Canadian) Society," The Canadian Historical Review 100, no. 4 (December 2019): 603-605.

${ }^{8}$ Catherine J. Kudlick, "Disability History: Why We Need Another 'Other"' The American Historical Review 108, no. 3 (June 2003), 765. Kudlick's characterization is not of the field's possibilities, but of how scholars tended to treat it - of limited interest, overly institutional and professional, and outside of serious
} 
the early twentieth century, though it does end at what is arguably the apex of this limited political influence and visibility of Western Canadian deaf communities before the 1970s, and shortly before a collapse of Western Canadian deaf influence over education and linguistic policy by the late 1930s. This study is primarily about the fight for access to education for deaf children, not directly about other political battles central to deaf activism such as sign language rights and deaf employment, though these are featured here.

If the study of history is the exploration of "change over time," the crosswinds between change and stasis is a central tension in this work. Simply stated, the change charted over the period 1880 to 1931 here is largely limited to the deaf side of the analysis, while the hearing side shows brief periods of opening up to deaf perspectives usually limited to periods in the years preceding the founding of deaf schools, like 1888-9 in Manitoba and 1927-31 in Saskatchewan. On the hearing side of these political and cultural processes, there is largely ignorance and disinterest. As sociologist Erving Goffman noted, the work to manage stigma and the unease it can generate falls on the stigmatized, and the story of deaf people and communities in Western Canada bears out his observation. ${ }^{9}$ This study argues that once educational deficiencies in state formation are seemingly addressed, hearing people, or at least those with little or no experience with

\footnotetext{
study. Other recent work that has addressed Kudlick's call to use a lens of disability to interrogate "what it means to be human" in the Canadian context include Joanna Pearce, "Not for Alms but Help: Fund-Raising and Free Education for the Blind," The Journal of the Canadian Historical Association 23, no. 1 (2012): 131-156 and Jason Ellis, A Class By Themselves?: The Origins of Special Education in Toronto and Beyond. (Toronto, University of Toronto Press, 2019). For a good overview of this and related fields, see Geoffrey Reaume, "The Place of Mad People and Disabled People in Canadian Historiography: Surveys, Biographies, and Specialized Fields," The Journal of the Canadian Historical Association 28, no.1 (2017): 277-316. I will return below to what I mean by evoking "state formation."

${ }^{9}$ Erving Goffman, Stigma: Notes on the Management of Spoiled Identity (New York: Touchstone, 2009 [1963]).
} 
signing deaf people, continued the work of other aspects of settlement and colonialism in "the West." These perceived deficiencies often began as trouble around perceived "borders," both geographical and cultural - both of which played into the story that crowns this study, the WCAD campaign to found a new Saskatchewan School for the Deaf from 1927 to 1931.

Borders, as a body of recent scholarship has shown, are continually negotiated, historically contingent, and often troubled. A growing transnational literature on the permeability and contingency of the Canadian-American border has focussed on Indigenous and Metis contestation and maintenance, ${ }^{10}$ familial relations and networks that straddle and trouble the project of border making and maintenance, and decentering the nation state as the sole body affected and established by border making. ${ }^{11}$ There is only a small body of literature that has focussed on the permeability and construction of borders within Western Canada itself, save the political literature of the "making of the Canadian West" that framed this history as the realization of a form of state building linked to both Central Canada and a British tradition. ${ }^{12}$ This study will examine the formation of provincial borders not only within the boundaries of provincial-federal dispute over territory and jurisdiction, but also the abrogation and acceptance of

\footnotetext{
${ }^{10}$ Michel Hogue, Metis and the Medicine Line: Creating a Border and Dividing a People (Regina: University of Regina Press, 2015).

${ }^{11}$ Some key recent literature that has made up a "borderlands" perspective includes Thomas Bender, $A$ Nation Among Nations: America's Place in World History (New York: Hill and Wang, 2006); Sheila McManus, The Line Which Separates: Race, Gender, and the Making of the Alberta-Montana Borderlands (Lincoln: University of Nebraska Press, 2005); Benjamin Bryce and Alexander Freund, "Introduction," in Entangling Migration History: Borderlands and Transnationalism in the United States and Canada, Benjamin Bryce and Alexander Freund, eds., 1-13 (Gainesville: University Press of Florida, 2015).

${ }^{12}$ For example: W.L. Morton, Manitoba: A History (Toronto: University of Toronto Press, 1957); L.G. Thomas, The Liberal Party in Alberta: A History of Politics in the Province of Alberta. L.H. Thomas presented state formation differently, as the reluctant and limited achievement of politicians in the NWT who saw themselves in a dependent, but necessary, colonial relationship with Ottawa. L.H. Thomas, The Struggle for Responsible Government in the North-West Territories, 1870-1897 (Toronto: University of Toronto Press, 1956).
} 
responsibility. Deaf education is merely one element of a larger process that deserves concerted study beyond a small body of literature that has theorized the concept of a resource-rich "North" as a lodestar of Western provincial policy in the late nineteenth and early twentieth-centuries. ${ }^{13}$ If a western province wanted to harden its borders, ensure provincial control over key social jurisdictions, and develop economic trajectories from distinct futurities, it needed to accept responsibility as well. ${ }^{14}$ One of these responsibilities, accepted by Manitoba and rejected by Saskatchewan until 1931 and Alberta until 1955, was the extension of compulsory schooling to deaf citizens.

This study, then, borrows from borderlands and transnational perspectives that decenter the nation state, but also seeks to relocate the dynamics around the growth of the state at the provincial level. In the absence of any federal involvement in deaf education from 1892 to 1930 s, the long process of ensuring access to education for deaf Albertans and Saskatchewanians involved the hardening of a jurisdictionally porous and geographically vague border between Manitoba and the two provinces had to be developed through practice and institution-building. As we will see, this process often mystified those provincial officials who were responsible for education and child protection.

\subsection{State Formation - Theory and Practice}

Provincial states undertook these institution building projects for practical and symbolic reasons linked to filling a perceived deficiency in services and provisions that influential individuals had lobbied in favour of. These institutions also became symbols

\footnotetext{
${ }^{13}$ See, for example, Jim Mochoruk, Formidable Heritage: Manitoba's North and the Cost of Development (Winnipeg: University of Manitoba Press, 2004).

${ }^{14}$ The term "futurities" will be defined and discussed in detail below.
} 
of the state's largess and modernity. Deaf schools, homes for "incurable children," mental hospitals, and other new nineteenth-century institutions were represented by a pastiche of large but functional architectural design with neoclassical columns and other elements, meant to project power and tradition even if they could lack internal design consistency. They were also publicised through print campaigns in partisan newspapers, and, later, film projects like The Ontario School for the Deaf, released in 1925. Deaf schools could be lucrative sites for patronage favours doled out by Liberal or Conservative politicians, and for this reason, were often spread out in small communities whose local officials saw economic opportunity through the creation of jobs and government contracts. ${ }^{15}$ E.A. Heaman, in her discussion of the state in Canada, argues that "The state was nothing if it was not a striking material presence, but the quality of the state as it was dispersed through society - the difference between the loaf of bread that was a state instrument and the loaf of bread that was not - came down to one's perception of the relationship between that loaf and the social order as a whole." ${ }^{\prime 16}$ This perception could not be dictated, but it could be influenced through architectural largesse, patronage, and public relations that represented new institutions that could be little more than Potemkin villages. The maintenance of provincial borders were, to an extent, represented by these institutions, like the Ninette Insane Asylum, the Alberta Provincial Training School in Red Deer, or the Weyburn Mental Hospital, though deaf education remained an exception to this provincial state building process, persistently an

\footnotetext{
${ }^{15}$ David Banoub, "The Patronage Effect: Civil Service Reforms, Job-Seeking, and State Formation in Victorian Canada," (PhD diss., Carleton University, 2013). This system of patronage, argued French sociologist Andre Siegfried in 1906, stood in for a lack of cultural cohesion at the center of the Canadian state and, therefore, held the country together by de-escalating friction between French and English Canadians. See Andre Siegfried, The Race Question in Canada (Toronto: MacMillan, 1907 [1906]). ${ }^{16}$ E.A. Heaman, A Short History of the State in Canada (Toronto: University of Toronto Press, 2015), 2.
} 
interprovincial matter in the region until 1965. This study partly concerns how Alberta and Saskatchewan asserted authority over deaf education in the absence of their own institutions, and why deaf and blind schools were among the last institutions for "dependent" children built in Prairie Canada.

State formation is a central thematic pillar of this study. While dealing only glancingly with the centralized Canadian state, this study theorizes states at the provincial level, and argues that a minority of interested citizens worked to force states to build deaf schools using both a common liberal futurity and a rhetoric around state formation in an age of rampant "boosterism" and provincial clamouring for scant, but growing, resources amidst the colonization of the west. The state, however, is a difficult concept to concretize. Sociologist Michael Mann's four-volume work on the emergence and maintenance of states, The Sources of Social Power, provides an expansive categorization of different theories proposed by sociologists, political scientists, and historians, and will be the key theoretical underpinning of what I mean by the "state" and "state formation" in this study. What is the state? Is it a place, or a series of people and institutions? Does it act on the terms by which it is "captured," or does it act in accordance with its own class and managerial interests? ${ }^{17}$

The state is one social body that wields power. Social power, most elementally, is "the ability to affect the behaviour of others," or "the ability to pursue and attain goals through mastery of one's environment." ${ }^{18}$ For this study, a general definition of power

\footnotetext{
${ }^{17}$ Michael Mann, The Sources of Social Power, Volume II: The Rise of Classes and Nation-States, 17601914 (Cambridge: Cambridge University Press, 1992).

${ }^{18}$ The first quotation is from J.M. Whitmeyer, "Mann's Theory of Power - A (Sympathetic) Critique," The British Journal of Sociology 48, no. 2 (June 1997): 211. The second is from Michael Mann, The Sources of
} 
would gravitate toward the second, given the difficulty of establishing that a given behaviour is the result of the imposition of social power. Social power is not simply, however, wielded by the state. Mann argues that power can be differentiated between two modes. Authoritative power emanates from a centralized locale to enact social goals within a society, with examples running the gamut between centralized dictatorship and clearly defined and enforced political programs in liberal democracies. Diffuse power, Mann argues, "spreads in a more spontaneous, unconscious, decentered way through a population, resulting in similar social practices that embody power relations but are not explicitly commanded."19 Both types of power operate in liberal democracies, as evidenced by nearly congruous efforts in Canada and the United States to enforce public mask-wearing in both the 1918-19 influenza and 2020 coronavirus pandemics. Some jurisdictions have resorted to ordering mask-wearing, but only after initial public health campaigns had failed to ensure a suitable level of social pressure on and cost to those who would not wear masks. ${ }^{20}$ Within the distinctions between how power emanates, Mann has a further breakdown of different types of social power.

He identifies four distinct forces that influence social power: ideological, economic, military, and political. Until the early nineteenth-century, he argues, European states rested upon ideological and military power, with religious institutions and a growing military-fiscal complex dictating state spending and priorities. ${ }^{21}$ The nineteenthcentury liberal state, however, rested upon a merging of economic and political power,

Social Power Volume 1: A History of Power from the Beginning to AD 1760 (Cambridge: Cambridge University Press, 2012 [1986]), 6.

${ }^{19}$ Mann, Sources, Vol I, 8.

${ }^{20}$ This is as of the summer of 2020 - it is impossible to know where public health law will stand weeks or months from now.

${ }^{21}$ Mann, Sources, Vol II, xii. 
with the liberal state triumphing in many nation-states - and certainly Canada - as a balance between ensuring the diffusion and enforcement of power without the use of state violence. This liberal state, which characterizes those states examined here until the end of the period of study, relied on the logic and practice of capitalism and its vanguards in the west - speculation, railroads, military force against Indigenous people, the systematic use of starvation as a treaty-making cudgel - to rule.

This study will focus on two of the four sources of social power: ideological and political powers. Ideological power, as Mann describes, encompasses religious and political beliefs, as well as beliefs that undercut fears of diversities. These, all told, would include religious sects, political systems like socialism, communism, or market liberalism, and homophobia, sexism, racism, or ableism. This is not an exhaustive list, and indeed "ideological power" could encompass any shared systematic belief system that influences behaviour that remains impervious to argument or evidence. Mann describes ideological power as one that "derives from the human need to find ultimate meaning in life, to share norms and values, and to participate in aesthetic and ritual practices with others...change as the problems we face change...(and) fill in the gaps and uncertainties with beliefs that are not themselves scientifically testable but that embody our hopes and fears." 22 For the purposes of this study, I see hearing humanitarianism, which I will explain below, as an ideological source of power wielded by hearing people generally against deaf people.

Mann's description and operationalization of political power is more restrictive than I would like. Political power is, he writes, "the centralized and territorial regulation

\footnotetext{
${ }^{22}$ Michael Mann, The Sources of Social Power Volume IV: Globalizations, 1945-2011 (Cambridge: Cambridge University Press, 2013), 1.
} 
of social life...the provision of order over a given territory." Mann also "reserve(s) the term 'political' for the state- including local and regional as well as national-level government." ${ }^{, 23}$ While power is wielded by the state, the territorial and provincial states studied here delegated this power to private interests through Children's Aid Societies and Bureaus of Child Protection for so long because hearing ideological power allowed them to do so. They were also, for a time, stirred to responsibility by deaf and hearing non-state actors who, while they did not "capture the state," influenced its actions and priorities significantly. On this point, I do stretch Mann's theory to allow non-state actors and groups into changes in social power dynamics, because I feel that he reflects a dominant tendency in political sociology and history to downplay certain types of activity as non-political. Deaf advocacy, as we will see, was not merely ideological and it was certainly not a manifestation of military or economic power.

Though not all social power flows through the state in liberal societies, it is nevertheless important to define and describe the state for the purposes of this study. Mann proposes the condensing of the myriad of theories about the nature of the state into a few currents that work at cross purposes with each other. Both Marxist and liberal interpretations theorize the state as a fictitious space that can be captured by capital, in the former case, or by a bloc of the voting public, in the latter. This view of the state is "passive," and is either the Marxist's view of a conspiracy of capital, or "liberal democracy's...view of itself." 24 The latter view, called pluralism by Mann, has been the dominant view of the state in mainstream politics since the 1992 publication of Volume II,

\footnotetext{
${ }^{23}$ Mann, Sources, Vol IV, 2.

${ }^{24}$ Mann, Sources, Vol II, 46. Mann argues that Marxist and pluralist models view the state as nominally "passive," though I take issue with this perhaps misleading wording. He rejects this "passive" view of the state, however.
} 
due mostly to the collapse of the Soviet Union the year before. He contrasts this, however, with a state that does act, though more as a mediator between the interests of capital and "the people." The state, in his view, manages these relations, but is not simply an objective arbiter of social power. Rejecting a model of this managerial state he calls "cock-up theory," he argues that while states often take-up divergent interests and may represent what Philip Abrams has called "the unified symbol of an actual disunity," the state still represents the forest, and these divisions the trees. ${ }^{25}$ In Mann's estimation, the state manages, but this is merely a description of what it does. What is it?

Mann proceeds from Weber's definition of the state proposed in Economy and Society. Weber writes that "a compulsory political organization with continuous operations will be called a "state" insofar as its administrative staff successfully upholds the claim to the monopoly of the legitimate use of physical force in the enforcement of order. ${ }^{26}$ Mann argues that the monopoly of physical force is impossible for a state to achieve, although states work toward this goal. Mann recognizes this in his own definition, namely that,

1. The state is a differentiated set of institutions and personnel

2. embodying centrality, in a sense that political relations radiate to and from the center, to cover a

3. territorially demarcated area over which it exercises

4. some degree of authoritative, binding rule making, backed up by some organized physical force. ${ }^{27}$

Mann's definition is the theory of the state that I will use from which to begin my claims about "state formation" - the expansion of both state power and state involvement in

\footnotetext{
${ }^{25}$ Mann, Sources, Vol II, 53-54.

${ }^{26}$ Max Weber, Economy and Society: An Outline of Interpretive Society (Berkeley, CA: University of California Press, 1978 [1922]), quoted in Mann, Sources: Vol II, 55. Italics are Weber's.

${ }^{27}$ Mann, Sources, Vol II, 55.
} 
individual, family, and community life. Corrigan and Sayer offer helpful thoughts on state formation as well, in that state formation is less imposed from above than achieved through making the state itself a cultural formation ${ }^{28}$ - a key insight in Western Canada, where the liberal state's primary function before the 1930s was to endure safety and opportunity for the colonial project that pursued genocide against Indigenous people. By the 1930s as David Tough argues, a more interventionist state was forged as different groups of citizens penetrated the state and began to push its priorities toward ameliorating the economic and democratic problems of the nineteenth-century liberal state. ${ }^{29}$

Mann posits that state power forms through "crystallizations" that harden through "historical conditions under which the expectations of the state were formed and crystalized. ${ }^{, 30}$ Institutions themselves, therefore, form and change through time as they are lived in, publicised, fought against, and remain static in the face of changing public mores and opinions. Deaf schools and other provincial institutions had incredible staying power - or at least their facades did. The degree to which these institutions changed for the betterment of personal liberty within their walls depended upon the population "served" inside - institutions for intellectually disabled people were the last provincial institutions to reform - indeed the government of Alberta practised eugenic sterilization without patient consent until the early 1970s. ${ }^{31}$ Deaf schools, too, took decades to reform the practice of oralism once it became institutional practice in Winnipeg, Saskatoon, and Edmonton, dangerous problems of overcrowding persisted in Winnipeg from the 1890s to

\footnotetext{
${ }^{28}$ Phillip Corrigan and Derek Sayer, The Great Arch: English State Formation as Cultural Revolution (Oxford: Basil Blackwell, 1985).

${ }^{29}$ David Tough, The Terrific Engine: Income Taxation and the Modernization of the Canadian Political Imaginary (Vancouver: UBC Press, 2018); Ian MacKay, Reasoning Otherwise: Leftists and the People's Enlightenment in Canada, 1890-1920 (Toronto: Between the Lines, 2008).

${ }^{30}$ Heaman, The State in Canada, 2.

${ }^{31}$ Erika Dyck, Facing Eugenics: Reproduction, Sterilization, and the Politics of Choice. (Toronto: University of Toronto Press, 2013).
} 
the 1930s, and persistent problems of physical and sexual abuse have been documented in the mid and later-twentieth century. ${ }^{32}$ Federally and ecclesiastically-run Indian Residential Schools were clearly the last to reform due to the public's persistent support for the colonial and "civilizing" project they represented, with public accounts of mass deaths barely making waves in the public sphere.

These institutions are "crystallizations" of state power. This study is about how those crystallizations took place - why power and resources began to be spent in Manitoba in the service of deaf education, and why it was ignored and denied for so long in Saskatchewan and Alberta. I will also examine the nature of the changes wrought by and within the Manitoba School for the Deaf, primarily in Chapter Five, which traces the political and community growth of deaf people in Alberta and Saskatchewan. These crystallizations owe much to historical contingency and larger intellectual trends difficulties in sending children to Ontario in the case of Manitoba in 1888, progressivism and deaf political pressure in Saskatoon in 1927 - and this study will try to trace these as well as sources will allow.

\subsection{Prairie Canada as Borderlands}

What then do I mean by Prairie Canada? This study primarily looks at the old Northwest territories, a loosely-defined geographic expanse between Manitoba and British Columbia that achieved land borders by 1905 as the new provinces of Alberta and Saskatchewan, though Manitoba was not permanently defined until 1912 and Prairie Canada's process of state formation was in its initial shaky steps in the years immediately

\footnotetext{
${ }^{32}$ CTV Montreal, "\$20 Million Settlement for Victims of Abuse at School for the Deaf." (https://montreal.ctvnews.ca/20-million-settlement-for-victims-of-abuse-at-school-for-the-deaf-1.2646344) Accessed May 12, 2020. Since 2015, class action suits have been pursued against one school in Montreal, two in Nova Scotia, and four schools in Ontario.
} 
after Laurier gave assent to the new rump provinces that lacked control over the resources on and under their lands. I exclude British Columbia from the study except to outline differences in deaf educational development, if not practice, from Prairie Canada. Using the term "Prairie" is also problematic, as Manitoba is not included, nor are the parklands and boreal areas north of the early established railroad routes. All four Western provinces also shared in the colonial project of settlement and displacement, and mostly excluded Indigenous children and youth from the project of deaf education, unless they were adopted by settler families, and therefore on the road to "citizenship" as defined by the 1876 Indian Act.

The borders probed by this project are more numerous than the simply geographical and jurisdictional ones negotiated by and between the provinces. This project uses the concept of borders to make sense of the divisions that were created through cultural attitudes and institutional practice between deaf and hearing Canadians (Chapters Four and Five), as well as the borders between deaf Canadians and Canadians with physical and intellectual disabilities (Chapter Six). Both hearing and deaf Canadians practiced a border between hearing and not-hearing, and later (on the hearing side) between speaking and not-speaking. Of course, hearing does not physiologically exist on such a dichotomous divide, and hard of hearing Canadians were included on both sides, in both institution and cultural practice. An important site where these stark borders could become weak or inoperable was the family, where deaf children of hearing parents or hearing children of deaf parents often used sign language or "home sign" to work 
together toward emotional or economic goals. ${ }^{33}$ A key factor in the rise of oralism in Central Canada in the early twentieth-century and Western Canada by the 1930s was that hearing parents began to feel like the government was making the "speaking-not speaking" divide too unbridgeable, and that their children were being returned to them as members of a linguistic minority that they, or prospective employers, could not communicate with. ${ }^{34}$ These borders, like state crystallizations through institutions, were given the illusion of stability as hearing parents, deaf leaders, and hearing deaf educators all "played down" the issues around, and representations of, sign language in the early twentieth century Prairie West. Oralism shattered this by the 1930s, and the result was a very politically involved but disempowered deaf community by the 1940s. Deaf communities in the Prairie West, to put it more precisely, had only enjoyed political influence when social and economic conditions allowed them to accrue publicity on their terms - in Manitoba in the late 1880s and in Saskatchewan in the late 1920s - and this influence was always dependent upon the interest and sympathy of enough members of the hearing public.

\subsection{Deaf History/Disability History - Considerations and Cautions}

This dissertation foregrounds figures that have previously appeared in the historiography of deaf and disabled history in Canada - David Peikoff, R.J.D. Williams, and Duncan McDermid - but tries to highlight the importance of others like Mary Lonsdale, John Parker, and J.R. Cook to late-nineteenth and early twentieth-century deaf politics in Alberta and Saskatchewan. It also claims that the importance of an expanding

\footnotetext{
${ }^{33}$ R.A.R. Edwards, Words Made Flesh: Nineteenth-Century Deaf Education and the Growth of Deaf Culture (New York: New York University Press, 2012), 33-34.

${ }^{34}$ Robert Buchanan, Illusions of Equality: Deaf Americans in School and Factory, 1850-1950 (Washington, D.C.: Gallaudet University Press, 1999), 24-25.
} 
network of deaf organizations was integral to the political activities of deaf Western Canadians. The Winnipeg Silent Club, then the Winnipeg Association of the Deaf, and finally the Western Canadian Association of the Deaf represent not only geographical expansion of deaf organizations out of a small Winnipeg cadre throughout the region, but also a transformation of political commitment from fellowship and community in its own service to fellowship and community in the service of pursuing political goals that would benefit the lives of present members and their families, as well as a future imagined community of deaf North Americans.

The literature that has focussed on deaf organizations has very been concerned with the methods debate that raged from the mid-nineteenth century in North America, and with good reason - it was extremely important to deaf people. The first, and still only, expansive history of deaf communities and individuals in Canada, Clifton Carbin's Deaf Heritage, side steps this debate much of the time, at least until the 1970 s. ${ }^{35}$ Carbin's history shares the strengths and weaknesses of other community histories, in that it focusses on milestones and highlights individuals over associations - the latter allows for precise detail while the former tamps it down. Among the strengths of Carbin's work is its focus on culture and allowance for historical contingency. It may lack analytical sophistication, as it is written for the whole deaf community and not a scholarly one, but remains an excellent information source and the product of a mountain of detailed research. The work also perpetuates colonial myths, framing deaf settlers in the West as "pioneers" and settlers, though this perspective is useful in that it frames these settlers as

\footnotetext{
${ }^{35}$ Clifton Carbin, Deaf Heritage.
} 
they would have seen themselves. Much of the material in Chapter Five would be difficult to piece together without Carbin's work.

Earlier work in deaf history focussed on community origins and development through a lens of oppression. Harlan Lane's key books have argued for deaf community and culture to be taken seriously, and have focussed on the repression of sign language. ${ }^{36}$ John Vickrey Van Cleve and Barry Crouch's A Place of Their Own is a landmark work in the cultural history of American deaf communities, though it often repurposes reductive American national myths within the deaf community, ignoring rich transnational links. ${ }^{37}$ Two key American works have framed the methods debate from a wider historical rather than purely cultural - viewpoint, and remain standard bearers in the field. Douglas Baynton's Forbidden Signs argues that oralism was the product of a Gilded Age and Progressive era movement in American life to realize a mono-lingual, mono-cultural republic in the wake of the horrors of the American Civil War. While relying on mostly hearing intellectuals as sources, Baynton helpfully framed oralists as progressive reformers who saw the quashing of difference as a way of liberating deaf people and "restoring them to society." "38 Susan Burch's Signs of Resistance focussed on how deaf communities and organizations reacted to hearing paternalism and the oralist era. Burch shows that deaf people offered extensive and organized resistance to oralism, and did manage to slow down its implementation and prevent it from becoming completely pervasive within schools by exploiting its internal contradictions with the tenets of

\footnotetext{
${ }^{36}$ Harlan Lane, When the Mind Hears: A History of the Deaf (New York: Random House, 1984); The Mask of Benevolence: Disabling the Deaf Community (San Diego: Dawnsign Press, 1999).

${ }^{37}$ John Vickrey Van Cleve and Barry Crouch, A Place of Their Own: Creating the Deaf Community in America (Washington, D.C.: Gallaudet University Press, 1989).

${ }^{38}$ Douglas Baynton, Forbidden Signs: American Culture and the Campaign Against Sign Language (Chicago: University of Chicago Press, 1996).
} 
progressive education. ${ }^{39}$ Most importantly, Burch positions deaf people and activists within the political realm as agents, something that deaf history focussed only on hearing oppression can gloss over. While the present study only glancingly deals with oralism and focusses more on issues of access to education, these works have been crucial in framing the parameters and questions probed here.

Deaf history, and state responses to deaf demands for educational provision and opportunity, is often included under the umbrella term "history of disability," though many deaf people reject the identification of "disabled" in favour of an understanding of deaf communities as distinct linguistic minorities. Deaf historians and historians of deaf communities tend to frame deaf history as distinct from those of other disabled communities. Accessed critically, this preference represents a continuation of deaf responses to burgeoning eugenic policies in early twentieth-century North America, in which deaf political organizations accepted the imposition of stigma and eugenic policies upon intellectually and physically disabled people, while fighting an effective campaign against the imposition of laws against deaf marriage out of fears of the propagation of a "deaf race." ${ }^{\prime 40}$ Chapter Six, which outlines the hardening of the borders of deaf education in Western Canada to exclude these groups, is this dissertation's most direct contribution to the growing literature on this difficult history for deaf communities. I will use a "deaf and disabled" distinction here to reflect my growing conviction that the gathering of diverse disabled communities under an umbrella term further marginalizes diversity and celebrates the very category that disability studies seeks to drag out of an overly

\footnotetext{
${ }^{39}$ Susan Burch, Signs of Resistance: American Deaf Cultural History, 1900 to World War II (New York, NYU Press, 2002).

${ }^{40}$ A.G. Bell, "Memoir Upon the Formation of a Deaf Variety of the Human Race," National Academy of Sciences, 1883. Hathitrust.
} 
medicalized twentieth-century paradigm. One only needs to develop a syllabus and deliver a course termed "The History of Disability" to understand how little can link different stories, categories, and experiences beyond the imagining of a normative body in the nineteenth-century forward to the early twenty-first. In an academic setting where Disability Studies often finds itself in "Diversity Studies" departments, like at my own institution, what can DS say about this diversity? Is it merely a case of those within and without the normative body? Are we simply hardening existing and limited understandings of diversity?

This study uses the term "disabled" where pertinent because it proceeds from my training within a disability studies framework that uses a "social model" perspective. "Disabled" is, in this usage, less a pejorative noun and more of a verb - in that disabled people are "disabled" not by their bodies, but by a society that refuses to accommodate them. ${ }^{41}$ Disability Studies has profited greatly from Lennard Davis' insights around the role of the nineteenth-century in reproducing and enforcing "normality" in bodies and human language - an argument first taken up in Enforcing Normalcy, his collection of ground-breaking essays on the erection of borders around creating and recognizing normal and unmarked bodies. ${ }^{42}$ Rosemary Garland-Thompson's work has been formative in disability theory as well, as it challenged the notion that "impairment" and "ablebodiedness" were immutable and shared human characteristics through a "shift (in) our

\footnotetext{
${ }^{41}$ The social model perspective began in the United Kingdom, devised by Michael Oliver and other members of a 1970s and 80s neo-Marxist grouping of emerging scholars in Disability Studies, itself an emerging field. See Michael Oliver, "Activism and the Academy: Losing the Ideological and Material Battles," Disability and Society 34, nos. 7-8 (2019): 1028-1033.

${ }^{42}$ Lennard Davis, Constructing Normalcy: Disability, Deafness, and the Body (Chicago: Verso, 1995).
} 
conception of disability from pathology to identity. ${ }^{, 43}$ Notions of disability and ability, Garland-Thompson has argued, are products of culture like other judgements of human value and conceptions of normality and difference, including race and gender. Snyder and Mitchell, extending Garland-Thompson's ideas, have argued that the social sciences and humanities ceded this definitional ground to scientific fields for too long, and need to emphasize human diversity in order to work against what Foucault has theorized as "biopower" - a power derived from a merging of technology and politics that creates a "population" of a society. ${ }^{44}$ Bodies, through state power afforded by the census and medical practice, can be defined as practically "normal" and therefore sovereign, or outside of normality and therefore subject to life and death decision-making beyond personal political agency. ${ }^{45}$ Disability Studies has, then, focussed on framing disability as human diversity, but also exploring the political resistance of disabled people through disabled voices and sources. If the social model has been the dominant theoretical lens through which Disability Studies has approached disability and the medical model its primary opponent, a movement toward a cultural model that simultaneously fragments and internalizes disability beyond a block of "bodily difference" has been underway, especially in North American scholarship. ${ }^{46}$

Deaf communities were generally agreed to be the first "disabled" group to practice and insist upon a "cultural" framing rather than an individualized, pathologized

\footnotetext{
${ }^{43}$ Rosemary Garland-Thompson, Extraordinary Bodies: Figuring Physical Disability in American Culture and Literature (New York: Columbia University Press, 1996), 137.

${ }^{44}$ Sharon Snyder and David Mitchell, Cultural Locations of Disability (Chicago: University of Chicago Press, 2006).

${ }^{45}$ Michel Foucault, The History of Sexuality: An Introduction. Volume One (New York: Pantheon Books, 1978), 136. See also Bruce Curtis, The Politics of Population: State Formation, Statistics, and the Census of Canada, 1840-1875 (Toronto: University of Toronto Press, 2001).

${ }^{46}$ Anne Waldschmidt, "Disability-Culture-Society: Strengths and Weaknesses of a Cultural Model of Dis/ability," Alter 12 (2018): 67-80.
} 
one. This took place, in a North American context, early in the nineteenth-century ${ }^{47}$, although, according to Joseph Murray, it took the process of exclusion from linguistic and political normativity by hearing people to really make deaf people organize in the early twentieth-century, separately and within racially proscribed bounds, in an emergent process pursuing what he calls “co-equality.” Murray's 2007 thesis, which attempts to broaden deaf American historiography beyond a simple "oppressor/oppressed” dichotomy, is a very important precursor to the present work. ${ }^{48}$ He argues that processes of deaf assimilation to and resistance against hearing normativity were not hermetically sealed from one another, and that deaf people tried to practice choice on their own terms - work and live in hearing communities, but maintain deaf community connections. Both of these happened simultaneously, in other words. By co-equality, a term Murray borrows from George Doherty's Presidential Address to the 1893 World Congress of the Deaf, Murray means a "sense of permanent biculturality," simultaneous membership in national and deaf communities. ${ }^{49}$ Earlier scholarship on deaf history has, in Murray’s estimation, over-stated deaf separation from hearing social life, framing deaf life only in terms of oppression and resistance. This study will evaluate Murray's thesis in a Western Canadian context in order to see whether a similar deaf incorporation of regional and transnational deaf communities took place. ${ }^{50}$ As we will see in Chapter Four, this effect was largely borne out by a generation of deaf activists who were educated at the

\footnotetext{
${ }^{47}$ Burch, Signs of Resistance, 3-4.

48 Joseph J.Murray, “'One Touch of Nature Makes the Whole World Kin': The Transnational Lives of Deaf Americans, 1870-1924," (PhD diss. University of Iowa, 2007).

${ }^{49}$ Murray, "One Touch of Nature," 20.

${ }^{50}$ For Murray, this entailed turning away from regional and class identities in favour of a conception of the "deaf world" - a transnational community - and the strengthening of deaf identity.
} 
Manitoba School for the Deaf by the end of the First World War, who turned toward political, rather than purely recreational and cultural, expressions of organization.

\subsection{More Theoretical Underpinnings and Discussion: Humanitarianism, Rights, and Futurity}

In 1927, hearing mother Mrs. Thomas Stephens wrote to the WCAD during its campaign to convince parents to help pressure Regina into building a deaf school. "I understand of course the hardest problem your association is up against," she wrote, "is the absolute indifference of the majority of people and I might say frankly that a few years ago, I too would have been indifferent, but now the matter concerns me most vitally." 51 Stephens was pointing out something profound and central to this study. Without a personal connection to a deaf person, or having a deaf child, Western Canadians had a hard time conceptualizing the need for deaf education. Evans admits that she, formerly, did not see this as an issue, until her own child was identified as deaf. I argue that this is a clear dividing line between "humanitarian" and "rights" conceptions of deaf issues, that heavily overlap, though not exclusively, a hearing-deaf divide.

This study posits a dichotomy between the "humanitarian" ethos behind hearing responses to deaf issues and a "rights" ethos increasingly pursued by deaf people by the early twentieth-century. These distinctions are constantly challenged by exceptions, as dichotomies are, but a humanitarian-hearing and rights-deaf distinction is a very defensible way to make sense of changes within deaf communities after the nineteenthcentury and stasis in hearing communities in knowledge of, concern for, or motivation by deaf issues among hearing Canadians. It is also a principal reason that calling upon a

\footnotetext{
${ }^{51}$ Mrs. Thomas Stephens to R.J.D. Williams, October 19, 1927. Box 1 Correspondence, 1989-71, R.J.D. Williams Papers, University of Alberta Archives (UAA).
} 
state-forming impulse at times of strong public support for institution-building proved to be an effective strategy for deaf organizations. This dynamic is characteristic of twentyfirst century media representations of deaf issues - In April and May of 2020, the province of Ontario saw both the recognition of an uncertified ASL interpreter by Premier Ford - patting the interpreter, the province, and himself on the back for "doing this" for deaf Ontarians - as well as pieces written by deaf organizations and individuals calling for a meaningful right to qualified interpretation at press conferences that purport to be of universal public interest. ${ }^{52}$ The 1990 achievement of the Ontario NDP in electing Gary Malkowski, the first deaf MPP in Canadian history, amidst a larger deaf-led movement called Deaf Ontario Now! was tempered by the Rae Government's inability to pass Malikowski's proposed disability legislation. This pattern eludes the concept of a "nadir" or "peak" of deaf political influence, as these terms point to a teleological emplotment of deaf agency and suggest a past "Golden Age," as my co-Supervisor Kristin Snoddon reminded me in a response to an earlier draft of Chapter Seven. If many historical monographs have tragic emplotments in Hayden White's estimation, this work only escapes a comedic emplotment through its temporal bracketing - meaning that the status-quo is disturbed, progress is made, and the status quo is returned without meaningful change. ${ }^{53}$ Deaf organizations did become more outward-looking and politically active, but even the modest gains made by the WCAD in Saskatchewan by the end of the period under study were severely qualified by 1940 and gone fifty years later,

\footnotetext{
${ }^{52}$ CBC News, "'You're a Rock Star': Premier Heaps Praise Upon “Champion” ASL Interpreter," April 1, 2020. (https://www.cbc.ca/news/canada/toronto/ford-ontario-sign-language-guy-1.5517914). Kristin Snoddon's response to the provincial fascination with "Sign Language Guy" on her Twitter feed sums up this aspect of my thesis pithily: "Sign language interpreters are not like dogs or ice cream. They are skilled professionals.” Kristin Snoddon, @KristinSnoddon, April 6, 2020.

${ }^{53}$ Hayden White, Metahistory: The Historical Imagination in Nineteenth-Century Europe. (Baltimore: Johns Hopkins University Press, 1973).
} 
as the R.J.D. Williams School for the Deaf was slated for closure by the Progressive Conservative government. This does not, however, mean that deaf political organizing, or brief periods of hearing interest and longer periods of complacency, are not meaningful objects of study.

A key difference between deaf and hearing conceptions of deaf education and prospects was in differing futurities. "Futurity" is a burgeoning area of study in Disability Studies, following Alison Kafer's repurposing of theories dealing with marginalized “queer futurities.” Disabled futurities are often projected as the opposite of liberal futurities - conditional, bleak, and lacking solid grounding in sexual, familial, and biographical fulfillment. "Special education" programs were often formed with limited futurities in mind - the belief that disabled people could only expect to hold down employment that would guarantee them little more than a precarious hold on the margins of poverty or working class existence. ${ }^{55}$ This study will argue that a liberal futurity, based in preparing children vocationally, spiritually, and philosophically for a struggle to survive in a liberal economy, was shared by deaf and hearing individuals, though deaf futurity began to show signs of community-building by the early twentieth-century. Hearing people, simply stated, saw deafness as a tragedy to be managed through vocational instruction that would allow deaf adults to be productive citizens and stay off the relief rolls. This was a futurity in which future deaf workers had to be equipped to survive in order to save the state the bother. It was also an undifferentiated futurity in which deaf children were seen as sharing the same problems and opportunities, and most

\footnotetext{
${ }^{54}$ Alison Kafer, Feminist, Queer, Crip (Bloomington: University of Indiana Press, 2013).

${ }^{55}$ Buchanan, Illusions of Equality, 95-96.
} 
importantly, were denied individuality, a basic cornerstone of nineteenth-century liberal philosophy.

This study differentiates "deaf futurity" as a vision of a "co-equal" future with "liberal futurity," a vision of possible futures based on nineteenth-century notions of liberalism that highlight gendered expectations of work, achievement, and property ownership that see these achievements as synonymous with "ability" and "productivity." These terms, in normative imagining, contradicted the "dependency" that society could expect of disabled adults without institutional intervention. Canada, Ian MacKay argues, was a product of a liberal order that linked individual worth with property ownership and productivity. ${ }^{56}$ While MacKay's "liberal order framework" has been criticised as reductive and a truncated vision of liberalism in a historical context, it does much to explain what settler Canadians expected of those deemed to be political actors - who were able to meet the terms of Locke's Social Contract, and those who depended on others to live in a new liberal order - including women, children, disabled people, Indigenous Canadians on the road to citizenship, immigrants from Southern and Eastern Europe. Indigenous, Asian, and uneducated disabled adults were largely seen as outside of this order - perhaps able to contribute to it, but never able to truly join the polity or the franchise. ${ }^{57}$

Many deaf people saw their futures in different terms. Initially, sources show that deaf people publicly portrayed deaf futurity in an individualized way, foregrounding the

\footnotetext{
${ }^{56}$ Ian McKay, "The Liberal Order Framework: A Prospectus for a Reconnaissance of Canadian History," The Canadian Historical Review 81, no.4 (December 2000), 617-645.

${ }^{57}$ Indeed, women could not vote federally until 1921, (the Wartime Elections Act both enfranchised and disenfranchised women), women in Quebec until 1940, Japanese and Chinese Canadians not until 1947, Indigenous people not until 1960, and intellectually disabled Canadians not until 1993. These exclusions from the "liberal order" had real consequences for political and social lives.
} 
same liberal futurity with less of a tragic filter. A different conception of deaf futurity arose in Western Canada, or at least publicly, by the end of the First World War. This envisioned a future of deaf family and community as well as individual opportunity. In this study, this point is best exemplified by difference between two reports on the planning of the Saskatchewan School for the Deaf in 1929, one filed by the Saskatchewan Grain Grower's Association's Annie Hollis, and one by the WCAD's R.J.D. Williams. Williams joined Hollis in highlighting opportunity as a goal of deaf education, but also named the banishment of language deprivation through delaying sign language education, and the preservation and fostering of deaf communities within and without Western Canada. ${ }^{58}$ Both of these conceptions of futurity identified the need for effective and provincial deaf education, though Williams' more explicitly recognizes it as a right threatened by hearing apathy.

A recent and forceful argument in Canadian human rights history, espoused by Dominique Clement, frames "human rights" as a late-twentieth century phenomenon in Canada. ${ }^{59}$ Clement argues that what most Canadians from the nineteenth into the twentieth-centuries characterized as "rights" were really civil liberties - freedoms from government intrusion rather than the demands of services and protections due to the individual that the state owed to every citizen from birthright. This dissertation will broadly accept Clement's assertions while arguing that though his work deals with

\footnotetext{
${ }^{58}$ See Chapter Seven. "Language Deprivation Syndrome" is a more recent psychological diagnosis, coined by Hall, Levin, and Anderson in 2017. I use the term "language deprivation" to unify contemporary concerns about the effects of denying language development in children under the age of five, when language acquisition is central to later development. I am not using it to refer to Hall et al's proposed psychological diagnosis. Wyatte C. Hall, Leonard L. Levin, and Melissa L. Anderson, "Language Deprivation Syndrome: A Possible Neurodevelopmental Disorder with Sociological Origins," Soc Psychiatry Psychiatr Epidemiol 52, no.6 (June 2017): 761-776.

${ }^{59}$ Dominique Clement, Human Rights in Canada: A History (Waterloo: University of Waterloo Press, 2015), 11-12.
} 
disability explicitly, deaf history offers a group experience and example that differs from many other groups agitating for rights in that it appears far earlier than Clement's argument suggests. In making this argument, I will follow Bangarth and Tunnicliffe's recent article about the importance of a "rights" framework in Canadian history and how it can make deaf and disabled politics before the 1960s visible and operable in a theoretical sense. ${ }^{60}$ They argue that rather than overly concern themselves with periodization, human rights historians should look for citizen's movements that have pursued definable rights and "how rights discourses have been used in different contexts. ${ }^{\prime 61}$ Literature on human rights, they argue, have focussed on the postwar era because of both the increased visibility of "equal rights" campaigns, but also because historiographical disputes over how far into the past the term "human rights" can be meaningfully employed have led historians to mine the postwar era for the "origins" of the concept of "human rights," leading to "questions over the legitimacy of studying 'human rights' in earlier periods." ${ }^{62}$ If we look not only to "human rights" activism conceptually, but as a set of practices and political ideas, transnational deaf communities and many deaf individuals not only practiced this type of activism, but used the term "rights" and linked those rights to citizenship and birth rather than capacity. While it is clear that there were distinct class and racial lines between deaf people in early twentiethcentury North America, with many of those deaf involved in rights advocacy being a white, educated elite who were overwhelmingly (but not exclusively) male, deaf groups were no different than all other rights-seeking groups in the period.

\footnotetext{
${ }^{60}$ Stephanie Bangarth and Jennifer Tunnicliffe, "Writing Rights into the 'New' Political History," The Canadian Historical Review 100, no. 4 (December 2019): 638-653.

${ }^{61}$ Bangarth and Tunnicliffe, "Writing Rights," 640.

${ }^{62}$ Bangarth and Tunnicliffe, "Writing Rights," 641.
} 
I use "rights" as a term to differentiate it from the historiographically bound term "human rights," which carries significant internationalist connotations and political links to the Carter Administration's international efforts against Communist rule in the postHelsinki Cold War. ${ }^{63}$ Deaf groups in the early and mid-twentieth centuries fought for a right to education based on membership in the Canadian/American community, and used explicit language to demand this right on claim to humanity alone. Other rights fought for by deaf groups during the same period fit more comfortably in Clement's framework of civil liberties - advocating against driving bans, allowing deaf to serve in the Canadian Civil Service, and allowing deaf people to access insurance. The right to education was treated as more fundamental and inalienable by deaf groups because it was linked to language and perception - without education, deaf children suffered language deprivation. For hearing reformers, this deprivation robbed deaf children of knowledge of the world, of God, and of country. For deaf activists, it also robbed them of community and selfaffirmation. I will explore this difference more fully in Chapters Five and Seven. For this reason, my use of the term "rights" is bounded by the pursuit of a right to deaf education, rather than the search for other civil liberties denied by governments. Human rights, as a concept, was hardly officially formalized in the 1970s, but debates over rights and what they meant predate and follow from that decade. I, like Bangarth and Tunnicliffe, consider that what is central in analysing a rights vs. civil liberties difference is the

\footnotetext{
${ }^{63}$ The Helsinki Accords were a series of agreements between 1975 blocs led by the United States and the Soviet Union that froze the divisions between Communism and capitalism, and therefore East and West, in central Europe. The Soviet bloc countries agreed to abide by specified human rights laws in return for this recognition of Soviet territorial advance in 1944-45.
} 
consideration of "context and environment," namely "how those 'on the ground" conceptualized and used a language of rights..,64

I will also rely on Simplican's characterization of Locke's social contract as a "Capacity Contract," ${ }^{65}$ and argue that while disabled people have been subject to a humanitarian hedging of control over their own lives, deaf people by the early twentieth century were openly advocating for individual "rights" based on shared membership in a marginalized group. Deaf people may have had a sense of what a humanitarian framing meant, but they increasingly rejected it and formed a visible, public politics around pushing back against it. John Locke, in outlining his Social Contract, argued that capacity was integral to political membership. Simplican argues that the exclusion of intellectually disabled people from community stems from this Lockean caveat, as it has excluded racialized people and women. ${ }^{66}$ By the end of the nineteenth-century, white-male deaf Canadians had achieved the minimum recognition of political membership - the franchise - but were barred from a full participation in the "great scramble of men" ${ }^{, 67}$ due to still-limited educational access and being barred from a wide swath of jobs available to other white men. It was in response to these barriers, and in pursuit of a signing (and in some cases, oral) deaf community, that deaf Canadians began to group together to both work against social constraints and ensure deaf education while building community within and without deaf circles. While this study sees validation of Murray's thesis, in that deaf Western Canadians created communities to counter hearing disinterest and

\footnotetext{
${ }^{64}$ Bangarth and Tunnicliffe, "Writing Rights," 641.

${ }^{65}$ Stacy Clifford Simplican, The Capacity Contract: Intellectual Disability and the Question of Citizenship (Minneapolis: University of Minnesota Press, 2015).

${ }^{66}$ Simplican, The Capacity Contract, 27. See Charles Mills, The Racial Contract (Ithaca: Cornell University Press, 1997) and Carole Pateman, The Sexual Contract (Stanford: Stanford University Press, 1988).

${ }^{67}$ The Echo 26, no.6 (March 15, 1919), 4.
} 
oppression, this work suggests that this process may have taken place later in Western Canada. Hearing Western Canadians clearly did not fully accept their deaf neighbours into the regional settler community, and saw them as objects of scientific fascination, pity, and tragedy, as Chapters Three and Four argue. While powerful exceptions existed, like the McDermid family and others, they also handed over the operation of (Silent) Echo to deaf editorship by the late 1890s and supported, rather than directed, deaf politics. This would cease to be the case a few years after the period under study, when hearing parents' demands became paramount to the governments of Manitoba, Saskatchewan, and Alberta, and western Departments of Education became focussed on the methods question for the first time, to the detriment of sign language rights, until the 1980s.

While deaf activists increasingly pursued the right to education for deaf youth, hearing politicians and populations offered humanitarian thinking in response, with a partial exception during the late 1920s in Saskatchewan, as we will see in Chapter Seven. Humanitarianism is a contested and disparate term, but I will use it in a focussed way. By "humanitarianism," I mean the offer of state provisions without control over the larger intellectual frameworks that decide which provisions should be offered. My thinking here is framed by the disability rights mantra "nothing about us without us, ${ }^{, 68}$ which refers both to scholarship and service provisions, both of which necessitate disabled representation. Michael Gill and Cathy J. Schuland-Vials, in their discussion of disability rights in the context of post Great Recession government austerity in Britain, write of "the multivalent barriers disabled people face in an age troublingly determined by

\footnotetext{
${ }^{68}$ Withers, Disability Theory, 57.
} 
government decision-making. ${ }^{, 69}$ While recent in subject matter, this characterization is reminiscent of anthropologist Krista Maxwell's notion of "settler-humanitarianism." Maxwell argues that Canadian settler politics has focussed on "reconciliation" with Indigenous Canadians through publicising past injustice and working to "heal" Canadian society within a virtually unchanged colonial framework. ${ }^{70}$ This is not to argue that deaf Canadians were subjects of colonial rule, but that Canadian politics has held deaf and disabled rights at arms-length, preferring to scrutinize what is 'possible' for decades before committing to an expansive national Disability Rights Act in 2019, or ensuring ASL/LSQ interpretation at provincial and federal government press conferences and events only upon the onset of the 2020 COVID-19 crisis. $^{71}$ The rights of deaf Canadians to access publicity around the decisions made by their own governments have been doled out in a piecemeal fashion when activists make enough noise to disturb the status-quo. These rights, therefore, are contingent upon interest and politics, rather than inalienable, so they are continually dependent upon deaf protest and activism. Deaf groups have been working against this since the early twentieth-century, and this process was an important factor in the turn toward "co-equality" identified by Murray.

While I use "humanitarian" not in its usual international context, recent scholarship on humanitarian assistance from the Global North does contribute to my use of the term. Michael Barnett argues that the standard historical narrative of international humanitarian rhetoric, that begins with Henry Dunant's experience as an observer of the

\footnotetext{
${ }^{69}$ Michael Gill and Cathy J. Schlund-Vials, "Protesting the 'Hardest Hit': Disability Activism and the Limits of Human Rights and Humanitarianism," in Disability, Human Rights and the Limits of Humanitariansism, Michael Gill, Cathy J. Schlund-Vials, eds. (Burlington, VT: Ashgate, 2014): 3.

${ }^{70}$ Krista Maxwell, "Settler-Humanitarianism: Healing the Indigenous Child-Victim," Comparative Studies in Society and History 59, no. 4 (2017): 974-1007.

${ }^{71}$ I should add that both the Accessible Canada Act and provincial attention to ASL/LSQ interpretation has been inadequate, in that the Act only addresses institutions with federal funding.
} 
aftermath of the 1859 Battle of Solferino, and ends with both private and state humanitarianism falling prey to politics in an increasingly complex world, is insufficient. Humanitarianism has always included these elements - that is it has always served domestic politics and self-interest through the accumulation of soft power, it has not only recently "slipped into building states," and it was never primarily private. ${ }^{72}$ In Barnett's reappraisal, humanitarianism's link to state-building and development interest me most, as I see developments in Western Canada as being similar to Barnett's picture of making failed or faltering states "work" to the rhetorical benefit of donor states. The humanitarian impulse allowed hearing politicians and journalists to highlight and even support deaf issues that dovetailed with state-building enterprises, and to ignore those that did not, like linguistic rights and work against employment discrimination. While I use "humanitarian" as an outlook or motivation through which the state simultaneously provides and denies, rather than relying on existing institutional practice, I use "rights" explicitly and concretely when I refer to deaf political organizing.

I have chosen to use the term "humanitarian" to generalize most hearing responses to deaf issues, rather than the existing terms "ableism" and "audism." Both terms are extensions of a system of "-isms" that includes racism, sexism, and ageism. This family of terms, in my estimation, are too inflexible to encompass what I see in my sources. Though these words represent more than just "hate" or personal prejudice, and do in fact represent systems of repression, they fail to capture the strange mixture of pity, fear, and disinterest that often met deaf calls for rights, and often still do. "Audism," a term coined by Tom Humphries and widely used in deaf communities, is simply too

\footnotetext{
${ }^{72}$ Michael Barnett, Empire of Humanity: A History of Humanitarianism (Ithaca: Cornell University Press, 2011), 3 .
} 
inflexible to capture this strange mixture. ${ }^{73}$ Audism captures the reality of wider systems of oppression, and is perhaps closer to the term "white supremacy" than "racism." Yet "humanitarian," I argue, captures these in a more expansive way, as long as the reader understands that my use of the term comes from a negative connotation - where "humanitarianism" is often for the benefit of the giver, and places the donor in a place of power over the subject.

Similarly, Disability Studies scholars often focus on the idea of "charity" as a suitable term for an ethos that diametrically opposes a social model perspective. ${ }^{74}$ Like "humanitarian," the term "charity" captures an interaction in which the giver gives to increase their status, and the receiver is diminished and denied agency. But "charity" is a strange term to use to describe a system of educational provision that was primarily public - though a few small day schools did operate on the Prairies during the time under study. If the charity model opposes the social model, it cannot encapsulate the reality of a system that was, for the most part, not charitable.

Humanitarianism is, for the purposes of this study, an ideological power within Mann's characterization of the four types of social power. To put Mann's theorizing about social power into the vernacular of the present study will be a major task of the argument itself. Simply, though, I argue that the humanitarianism of hearing people is an ideological power that largely held sway over Western Canadian policy making and public expectation between the years 1880 and the mid-1920s. In Saskatchewan, at least, "organized" deaf people were able to gather allies and develop a political power that

\footnotetext{
${ }^{73}$ Humphries coined the term in his $1975 \mathrm{PhD}$ dissertation. H-Dirksen L. Bauman, "Audism: Exploring the Dynamics of Oppression," Journal of Deaf Studies and Deaf Education 9, no. 2 (Spring 2004): 240.

${ }^{74}$ Withers, Disability Theory and Politics, Chapter Four, "For Us, Not With Us: The Charity Model."
} 
challenged the dominant ideology of humanitarianism during the push to found the Saskatchewan School for the Deaf in the late twenties. Ideological power, however, returned with the complaints of hearing parents about the limited use of sign language at the SSD by the mid-1930s, as we will see at the end of Chapter Seven. Chapters Four and Five will clarify what I mean by "humanitarianism." The state indeed wields power, both authoritative and diffuse, but non-hegemonic interest groups can influence and transform state objectives through politics and publicity, at least for a time.

\subsection{Rights: Grounding the Term in Western Canadian Deaf History}

A short example of the explicit use of the term "rights" in early twentieth-century commentary on deaf education is in order here, to ground this introductory discussion. In the November 16, 1914 issue of Silent Echo, the paper reprinted a short essay from the Deaf Carolingian entitled "The Deaf Child's Right." ${ }^{, 75}$ The piece argued that deaf education is a child's right, but that the most common impediment to its realization was "the parents of some deaf children" who "will not send their children to school at all," rather than the government of North Carolina, which operated three deaf schools at the time. ${ }^{76}$ Much like earlier rhetoric from Principals Watson and McDermid before the NWT allowed its children to attend the MSD, The Deaf Carolingian blames parents for standing in the way of their children's rights, rather than the relevant governments. A key difference between Western Canada and the American South was that all states, by the early twentieth-century, had government-run deaf schools, so blaming parents was an acceptable form of soft criticism. As McDermid had turned to calling on the NWT and

\footnotetext{
${ }^{75}$ Silent Echo 23, no. 1 (November 16, 1914), 2. The Deaf Carolinian was the newspaper printed at the North Carolina School for the Deaf in Morgantown, N.C.

${ }^{76}$ One of these schools was for Black students, as North Carolina's education system was and remained segregated for decades. The NCSD at Morgantown was not integrated until 1971.
} 
Manitoba to come to a deal by 1893 , parents and the WCAD began to coalesce around a call for provinces without schools to begin to take responsibility for ensuring the right to education.

The Deaf Carolingian article links deaf education to modernity, progressive education, and a liberal futurity that was rooted in individual opportunity and ability. "Education is the cry of the age," the piece read. "Parents, think of your child's future in the days you cannot be near to protect him from the harder battles of life and send him to school to be trained and educated along lines that will insure his best development." 77 This appeal, to mostly hearing parents, calls on them to insure their child's rights. It does not call upon the state, like earlier arguments based on tax-paying citizenship - that parents of deaf children should receive services for taxes in the same way that parents of hearing children do. These were two key arguments to mobilize hearing families, employed together and apart, depending on context and availability of educational opportunity. The former represents a humanitarian strain of thought, while the latter more precisely calls for the rights of the taxpayer.

Deaf families envisioned "the deaf child's right" in a similar yet more expansive way. Hearing educators called upon parents and governments to avoid the problem of uneducated deaf adults who would become a burden on the state, and became more difficult to educate as they aged. Deaf parents, as we will see, understood this problematic delay in terms of language deprivation. By the 1920s, as we will see in Chapter Seven, R.J.D. Williams of the WCAD was giving presentations to progressive hearing audiences in Saskatchewan that explicitly argued for education as both a conduit

\footnotetext{
${ }^{77} S E$ 23, no. 1 (November 15, 1914), 2.
} 
for personal development to ensure participation in a liberal economy and a way of realizing deaf community development. Here, again, the distinction is in humanitarian thinking as opposed to rights-thinking. In the former model, if a child "falls through the cracks," it is a pity and a burden, while in the latter it is the denial of basic human experience and community.

\subsection{Deaf Chronicle: A Broad Overview of Popular American Deaf History}

Deaf history in North America has a popular, commemorative narrative that was important to deaf people in the late nineteenth-century, and remains an important touchstone. I will briefly touch on it, as well as some key historiographical sites of contestation, before taking up a more geographically and temporally focussed narrative in Chapter Three. This narrative, it is important to point out, references developments in deaf education, rather than cultural or community development, showing the importance of the struggle over education to the nineteenth-century deaf community that constructed and perpetuated this deaf American "origin story." It is not my intention here to contest this origin story, but simply to give the reader a background in popular North American deaf history that must be drawn upon at times throughout this study.

The story of American deaf education really begins in France, when Abbé Charles-Michel de L'Épée, a Parisian abbot, watched two girls sign with each other in the streets of Paris. The Abbé began a lifelong fascination with deaf people that led to him codifying existing Parisian sign language into a manual alphabet and sign system with French syntax that could be shared by hearing and deaf people. ${ }^{78}$ In 1760, L'Épée

\footnotetext{
${ }^{78}$ Versions of this story give L'Épée credit for "inventing the language of signs," though the earlier publication of Pierre Desloges book that outlines his use of sign discredits the assertion. Deaf Parisians also did not use L'Epee's sign system outside of the school, according to Laurent Clerc. See Desloges,
} 
founded the Institution Nationale des Sourde-Muets a Paris, the first deaf school in France, which grew to include students from other areas of the country, and became a public institution under the Napoleonic Empire. One of its first students, a graduate and teacher named Laurent Clerc, was working there in 1815 when an American visitor arrived from Britain.

This visitor, Thomas Gallaudet, was a Congregationalist Minister who had been asked by the parents of a deaf Massachusetts girl named Alice Cogwell to find a way to start educating deaf children in the area. Gallaudet sailed to Britain to meet with the Braidwoods, educators there, who rebuffed him because they saw future opportunity in educating Americans. Gallaudet then went to Paris to see Abbé L'Épée's school, run by Roch-Ambroise Cucurron Sicard since L'Épée's death in 1789. After meeting Clerc and convincing him to come to the United States to found a deaf school with him, Gallaudet observed what he could of the Paris system of education. Clerc and Gallaudet sailed for the United States, with Clerc learning English and Gallaudet learning French Sign Language on the trip. After successfully lobbying multiple New England legislatures and gathering support from private donors, in 1816 they opened the American School for the Deaf in Hartford. ${ }^{79}$ For decades, the influence of Clerc, with Thomas Gallaudet and his son Edward Miner Gallaudet, assured that the "American system" of deaf education would be known as a primarily manual system, meaning that it relied on sign language and the one-handed manual alphabet, borrowed from FSL.

Observations d'un sourde et muet sur un cours elementaire d'education des sourdes et muets publie en 1779 par M L'Abbe. Project Gutenberg, https://www.gutenberg.org/ebooks/39363.

${ }^{79}$ Edwards, Words Made Flesh, Chapter 1. 
The narrative then takes a dark turn. The Clarke School, founded in 1867, represented a newfound hearing discomfort with the idea of a deaf subculture that hearing authorities saw as isolated and impoverished. A teacher at Clarke, a Scottish proponent of a defunct system of deaf-hearing communication called Visible Speech named Alexander Graham Bell, began to advocate that deaf people learn only through oral methods, like the ones that prevailed at Clarke. Over decades, using his celebrity as the inventor of the telephone, Bell convinced hearing Superintendents to abandon manual instruction. By the 1890s, most American schools were either oral or "combined" - the latter term meaning that students were either in a manual or oral stream. By the 1920s, the narrative continues, oralism had won out.

The commemorative narrative has several underlying themes that are central to deaf community-making. ${ }^{80}$ One is the theme of a deaf founder for American deaf schools, though Gallaudet always received top-billing, so to speak. Laurent Clerc, with his use of FSL, ensured that the "American system" would remain manual for decades, and avoid the legacy of British deaf education, which turned to oralism by mid-century with several streams of German deaf education. The predominant narrative is one of a "golden age" of sign in schools, deaf teachers, and relative harmony between deaf and hearing people, especially on Martha's Vineyard, where many hearing people learned and used MVSL. ${ }^{81}$ This harmony was destroyed by A.G. Bell, who also argued against deaf immigration to the United States and Canada, as well as deaf intermarriage. ${ }^{82}$ Another important thread

\footnotetext{
${ }^{80}$ Vickrey Van Cleve and Crouch, A Place of Their Own.

${ }^{81}$ Nora Groce, Everyone Here Spoke Sign Language: Hereditary Deafness on Martha's Vineyard (Cambridge: Harvard University Press, 1985).

${ }^{82}$ A good discussion of these aspects of Bell's activism can be found in Jennifer Esmail, Reading Victorian Deafness: Signs and Sounds in Victorian Literature and Culture (Athens, OH: University of Ohio Press,
} 
was a French legacy, rather than a British one, that oriented American deaf toward that country, which was seen as more friendly to sign language throughout the nineteenthcentury. Finally, the figure and name of "Gallaudet" became a linguistic signpost for deaf rights in the United States and Canada for two centuries after Thomas Gallaudet's trip across the Atlantic Ocean. His name would adorn America's first deaf University, be evoked in deaf publications, and even appear as the middle name of one of the children featured in this study. It would also accrue power for E.M. Gallaudet, Thomas' son, who argued for combined education against Bell for decades during a vicious methods debate from the 1880 s to the early-twentieth century. Images of Thomas Gallaudet and Laurent Clerc appeared in deaf publications everywhere, often in mastheads that gave the air of apotheosis to the men.

Europe is also an important counterpoint to this American narrative. At an 1880 Conference of Educators of the Deaf in Milan, Italy, mostly hearing European officials decided to reject "the American method" in favour of the "German method"-i.e. rejecting sign instruction for oral instruction. I will simply state here that the 1880 Milan Congress was, and remains, a powerful symbol of hearing oppression for American deaf, despite the fact that it had little initial effect on American instruction. In Chapters Three and Four, I will paint a more complex picture of the causes of the wave of oralism that swept Europe, then the United States and Canada. It is important, however, to recognize that the Milan Congress, with Bell, became the antithesis to Gallaudet and Clerc's apotheosis, with both man and event featuring in deaf explorations of hearing oppression

2013), Chapter Four, “A Deaf Variety of the Human Race?” We will deal with Bell in more detail in Chapter Three. 
in publications, popular webpages, and vlogs shared by and created within deaf communities.

\subsection{Overview of Structure}

This dissertation will emerge over eight chapters in total, including a conclusion. Individual chapters will themselves feature reviews of the theory and historiography that is relevant to the ground covered. The structure of this dissertation varies slightly from the normal practice of having a single introductory chapter, as the first two chapters here serve as introductions. The overall organization of the dissertation reflects a thematic sorting of my reconstruction of the history of deaf education in Western Canada. It begins broad, by examining deaf immigration and the development of the Manitoba School for the Deaf and almost-total barring of Indigenous students from the school. It then narrows its focus on distinct populations, moments, and themes in order to draw out the wideranging implications of Alberta and Saskatchewan's policy developments in deaf education and the formation of fluid cultural attitudes toward deaf people on the Prairies.

Chapter Two will cover issues of positionality and methodology, including the sources used for this study, as well as the story of my own successes and struggles in finding pertinent materials in archives across Manitoba, Saskatchewan, and Alberta. Chapter Three will offer a narrative view of the beginnings of deaf education in Manitoba, the initial struggles over provision in the neighbouring Northwest Territories, and will situate deaf education as a product of the colonial displacement of Indigenous peoples after the Canadian purchase of "Rupert's Land" from the Hudson's Bay Company in 1869. Chapters Four and Five are closely connected to each other, with Four framing hearing responses to deafness at the familial and policy levels, and Five tracing the 
beginnings of deaf political activism and following prominent deaf farming communities in Saskatchewan, like the community of Lipton. These chapters flesh out my distinction between humanitarianism and rights more completely, giving it an evidentiary and narrative basis. In Chapter Six, I look at how the turn toward eugenics and increasing public concern over intellectual disability manifested at the Manitoba School for the Deaf. The MSD, this chapter argues, helped define and harden notions of "feeble-mindedness" through the process of rejecting applicants who showed signs of being either being both deaf and intellectually disabled or simply intellectually disabled. This chapter shows how an example of Mann's notion of "crystallizations" of state power was influenced by the MSD's insistence on the "educability" of its students, while rejecting those who would give the school the aura of an asylum, rather than a school. Finally, Chapter Seven will form a narrative and analytical picture of the 1927-1931 struggle for a new Saskatchewan School for the Deaf, through which the Western Canadian Association for the Deaf forged a unique example of politics though hearing allies and deaf families in Saskatchewan to drive the province toward state formation on its own terms, at least for five or so years after the founding of the SSD in 1931. Together, these chapters will tie deaf education and emerging deaf communities to state formation in Alberta and Saskatchewan through political activism and direct involvement with the constructions of institutions which "served" them. They will also endeavour to contest the dominant historical narrative that a politics around "rights" is a late-twentieth century phenomenon, and that activism by disabled people only begins in the 1960s after the influence of the American Civil Rights Movement. 


\section{Chapter Two: Positionality, Process, and Misgivings}

"While waiting for me to write, my acquaintance likely swears at me for not having learned to talk with my tongue and read his lips. His time is valuable to him. While I mentally anathematize him for not having learned the manual alphabet and signs. My time is valuable to me. Outwardly, both of us are all smiles and sweetness...We part with suppressed oaths, and a determination to dodge each other in the future."

Albert Ballin, $1931^{1}$

\subsection{Introduction}

This project began in the spring of 2013, in a Historical Methods class at the University of Calgary. Tasked with producing an analysis of a primary source, I chose the Volume 1, no. 1 edition of Silent Echo. I found the paper fascinating, but knew nothing about the Manitoba School for the Deaf or deaf education, really. With the support of Drs. Jewel Spangler and David Marshall, I decided to enter the MA program at Calgary to study the MSD for my MA thesis. In this study that covered the years 1884-1920, I covered the expansion of educational opportunity and the growth of the state in Manitoba. As I studied Manitoba, however, I came across numerous sources that suggested the absence of many students from the Northwest Territories, and then Alberta/Saskatchewan. Why this stark split? I decided to study the lack of state development in the field of deaf education in Alberta and Saskatchewan for my $\mathrm{PhD}$ program at Carleton. It all seemed fairly clear to me.

Alberta and Saskatchewan weren't populous enough, primary sources from Winnipeg and Regina suggested. As the population of the Prairies grew, so would the number of deaf schools. As I looked at sources during my initial $\mathrm{PhD}$ research trip in Winnipeg and Regina in 2018, I found that Saskatchewan officials themselves had no

\footnotetext{
${ }^{1}$ Albert Ballin, The Deaf Mute Howls (Washington, D.C.: Gallaudet University Press, 1998 [1931]), 50.
} 
perspective on the issue. Correspondence responding to letters from the Western Canadian Association of the Deaf was preceded by inter-governmental letters asking if the province had a compulsory statute for deaf children. These conversations were confused and lowered the level of legal discourse to opportunistic political discussions. How was this possible? How could individuals like James Gardiner, the educationfocussed Premier of Saskatchewan from 1926 to 1929, kick the can down the road on this issue for decades? How could people, who empathized with the assertion of a right to education and saw deaf children as tragic figures in need of deliverance, know nothing of the issue? These questions gnawed away at me and were only complicated by a concerted dive into deaf and governmental sources that documented individual deaf interactions with the educational system in great detail. In the course of studying to develop satisfying answers to these questions, I became enthralled with deaf history, studied disability theory under Kristin Snoddon and Roy Hanes at Carleton, and poured these efforts into teaching The History of Disability at Carleton in 2018 and 2019. Despite my enthusiasm for the content and project, other questions continued to bother me.

\subsection{Positionality}

Outlining one's positionality is an important obligation for any scholar of human subjects. It refers to identifying one's socioeconomic, racial, and abled position in relation to those they are research and writing about. Positionality affects how studies are constructed, which sources are chosen, and which research questions are pursued. ${ }^{2}$ In the interest of outlining my positionality to my topic, it is most important to say that I am a

\footnotetext{
2 "Positionality," The SAGE Encyclopedia of Action Research, ed. by David Coughlan and Mary BrydonMiller, 2014. DOI: https://dx.doi.org/10.4135/9781446294406.n277
} 
hearing man. I have spent five years learning ASL in Calgary and Ottawa in class settings, but I am very much still a learner with a very limited vocabulary. Through the process of studying Canadian state formation and expanding the history of rights provision in Canada, I also study a community history that doesn't belong to me. I am aware that some in the deaf community will object to a hearing man studying this history, and I understand that twenty-first century developments in deaf politics make my position precarious. I identify with R.A.R. Edward's piece on teaching deaf history as a hearing researcher, and the sincere recognition of privilege that she offers in her discussion of experiencing pushback from deaf students in her deaf history class. ${ }^{3}$ While the logical endgame of her assertion that barring hearing people from teaching deaf history means that the opposite would apply (i.e. deaf teachers could not teach anyone else's history) seems to me to be incompletely considered and inflexible, Edward's piece both lowered and heightened my anxiety about my chosen field. I would take it for granted that it would be up to me to prove my expertise and worth in the classroom, and to hurl myself at the mercy of the jury. I will also say that deaf people and organizations that I have reached out to in the course of this study have been open, welcoming, and generous with their time and resources.

Responses from my hearing friends and colleagues to my research have been surprisingly uniform. As Simplican argues, many studies of disability in the sciences and humanities lean into a personal identification of the non-disabled researcher with a disabled family member. Many of my colleagues ask me, when I introduce my topic, "do you have a deaf family member?" Initially, I would just say “No," but with each

\footnotetext{
${ }^{3}$ R.A.R. Edwards, “Teaching Deaf History,” Radical History Review 94 (Winter 2006): 183-190.
} 
encounter with this question, I began to think about Simplican's argument, that locating research motivation within the familial sphere renders a topic extra-political. ${ }^{4}$ Would I be asked, for example, if I had a family member serving in the military if I chose to study military history, or a relative at the table in Charlottetown if I studied Canadian Confederation? That would be strange, but in disability studies, it is a common occurrence. I try not to be too forceful about it, but I generally respond now by saying "I'm trying to expand the notion of what has been political all along," rather than simply responding that "I study this because deaf people are important," because I genuinely understand why people ask this question and that they mean well. These questions are an example of the kind of thinking that I identify as "humanitarian" - that one would only study deaf history and hearing responses to deafness out of principled altruism.

Other responses to my research have crossed into darker territory. At one conference in 2018, I presented a paper on the Groom Expedition on a "left overs" panel - the sessions which disability scholars tend to end up at where organizers have lumped outlying topics together. ${ }^{5}$ I spent a few minutes talking about A.G. Bell and his response to the Groom scheme, after discussing his opposition to deaf marriage and a looming “deaf race." The first question I was asked was from a tenured faculty member at an Ontario university, who focussed on Bell's eugenics. "Why," the questioner asked, "would you want a deaf child to be born? Why was Bell wrong?" Flummoxed, I struggled to avoid eye contact with other audience members as the air drained from the room. My response, after a few breaths, was terse and unsatisfying to the professor. "You should read about the deaf community," I replied, "you should look for a deaf

\footnotetext{
${ }^{4}$ Simplican, The Capacity Contract, 15.

${ }^{5}$ The Groom Expedition is discussed in detail in Chapter Three.
} 
perspective." After they stated defensively that they felt that their child's Autism Spectrum Disorder diagnosis gave them licence to speak so openly, I repeated my answer. The moderator wisely moved on to a question about museum funding (it was the 'leftovers panel,' after all), and the breach seemed sealed. This incident, however, has stayed with me as a reminder that the line between a "humanitarian" ethos and a eugenic one is real, and they are only a single step apart.

This study is also informed and shaped by current trends in deaf education in Western Canada. The Manitoba School for the Deaf was closed between 1940 and 1965, the Alberta School for the Deaf D was opened in 1955 and still operates, and the Saskatchewan School for the Deaf was closed in 1991. There was only a relatively brief period in which all three Prairie provinces operated deaf schools, the twenty-six from 1965 to 1991, though day schools did proliferate in Winnipeg before 1965. Since the 1990s, provincial cuts and an increasing emphasis on mainstreaming have put pressure on deaf activists and advocates for ASL education. Alberta, while operating the ASD, has seen serious cuts to supports for deaf students in mainstreaming situations, including a shortage of interpreters that allowed deaf students to be mainstreamed at only one school in Calgary, for example. This instability of funding for deaf education in the neoliberal era has led me to reflect on the gains won by activists in the 1880s and 1920s as contingent. The MSD and SSD need to be considered not as institutions erected and standing statically over decades, but, as facades that age, regenerate, close, and shrink depending on the waxing and waning of political support for deaf education. The banning of sign language at these schools changed them drastically in ways not visible from the outside, just as the instatement of total communication, and then ASL, changed school 
culture and the composition of teaching staff and employees. This is a look back on struggles around deaf education from the standpoint of great precarity, and (as it feels sometimes) the end of the residential deaf school era.

I try to follow Geoffrey Reaume's reflexive guidelines in doing disability history. Reaume, a scholar of Mad History in Canada, argues that the commitment to reconstructing histories that respect and honour disabled subjects is "a never-ending process. ${ }^{" 6}$ Establishing links to non-academic readers and communities and being accountable beyond the academic realm is important for Reaume, as is weighing the harms and benefits of using sources created against the will of disabled subjects in the past. Individual researchers will make these choices, but it is central that they remain accountable to disabled communities for these choices. Given my positionality as a hearing, middle-class, white man who benefits professionally from the study of deaf history, this accountability is both important to me and a commitment that will extend past the defence and submission of this dissertation.

\subsection{Disability Studies and Human Diversity}

Disability is a failure to imagine diversity. It is a verb masquerading as a noun. Disability Studies scholars have, since the 1990s, sought to locate disability as yet another site of exclusion based on bodily difference, similar to differences along the lines of race and gender. Douglas Baynton has gone so far as to argue that the language of disability has been used to underwrite all exclusions - exclusions of racialized people, immigrants, women, and people living with poverty. In his formative 2001 article, Baynton argues that in the post-Enlightenment era, disability has been used as a

\footnotetext{
${ }^{6}$ Geoffrey Reaume, "Posthumous Exploitation? The Ethics of Researching, Writing, and Being Accountable as a Disability Historian," in Untold Stories: A Canadian Disability History Reader, eds. Nancy Hansen, Roy Hanes, and Diane Drieger (Toronto: Canadian Scholars Press, 2018), 36.
} 
justification for existing inequalities that may have seemed unjust within an emerging American republicanism that "refused to take for granted inequalities between persons and groups." ${ }^{, 7}$ The influential implication of his argument is that the proliferation of disability history is a search for the historical meanings of a disability that is "everywhere in history, once you begin looking for it, but has been conspicuously absent from the histories we write. ${ }^{\prime 8}$ Disability, argue Baynton and Kudlick in two formative papers in American disability history, is a theoretical lens similar to race, class, and gender. ${ }^{9}$ This lens-centric perspective has served the burgeoning field well, though historians of disability still find themselves either at "their own table," or "at the singles table," to use a wedding reception metaphor.

Baynton and Kudlick were responding to the marginalization of disabled subjects within an antiquated political history that set aside able-bodied, wealthy, white, Christian men as the subject for the search for agency and cause in histories of politics. This study responds in a different way - still "bringing disabled people" into the agency question, but also recognizing that the concept of "disability" was perhaps not as unified in the past as a singular theoretical approach may have led us to believe. This study calls into question the lumping together of deaf and intellectually disabled individuals under a common category, and explains that, at times, deaf people tried to set themselves outside of what they saw as more pernicious forms of disability by attempting to build a firewall around deaf schools to keep other groups out. Baynton's mantra, “disability is everywhere," has been a clarion call for a number of excellent complete or ongoing dissertations in Canadian history. These studies have largely treated disability as

\footnotetext{
${ }^{7}$ Baynton, "Disability and the Justification of Inequality," 33.

${ }^{8}$ Baynton, "Disability and the Justification of Inequality," 52.

${ }^{9}$ Kudlick, "Why We Need Another Other."
} 
constitutive of particular impairments - Joanna Pearce's study of blind education in Canada, Sara Spike's study of rural “modernist vision” in Nova Scotia, Susanne Commend's study of medical responses to childhood disability in Montreal, and Natalie Spagnuolo's dissertation on activism in and around the Huronia Institution in Ontario.

Sara Spike's examination of "modernist vision" in Nova Scotia problematizes narratives that set scientific knowledge and modernity/urbanity on the same side of the ledger exclusively. ${ }^{10}$ She argues that modernist conceptions of vision created a problem around those who were blind or had visual impairments, leading to a provincial effort to find rural blind Nova Scotians in order to educate and socialize them into "performing blindness" in acceptable ways. Modernist vision, in other words, entailed a strict dichotomy between vision and blindness, and imposed modernist notions of blindness on rural Nova Scotians who had more accepting and fluid attitudes to the abilities of their blind neighbours. ${ }^{11}$ The study deals with blindness and blind education in one chapter, preferring to use a "history of the senses" standpoint in which to frame the study's findings. This has notable strengths and drawbacks. A history of the senses perspective can foreground disability directly, by emphasizing difference through varying commands of senses, and focussing on how those differences were accommodated or understood culturally. It can also allow for histories of disability to be studied outside of institutional walls, unlike most histories that serve as institutional studies due to the lack of a diversity of sources. This perspective, however, is difficult to mend with a cultural model of disability, in which blind or deaf groups identify as distinct minorities based on

\footnotetext{
${ }^{10}$ Sara Spike, "Modern Eyes: A Cultural History of Vision in Rural Nova Scotia, 1880-1910." (PhD diss., Carleton University, 2016).

${ }^{11}$ Spike, "Modern Eyes," 257-258.
} 
difference. While well suited to Spike's study, the history of the senses is not a fix for the problem of reifying disability as a non-normative state, as it can flatten diversity itself. The history of the senses can also approach sensory disability from a problematic normative standpoint, given that many signing deaf people see themselves as a linguistic minority rather than allowing themselves to be defined through the experience of a hearing deficit. It can, in other words, run counter to the possibilities of community in disability histories, as well as conceptions of Deafhood and Deaf Gain. ${ }^{12}$

Susanne Commend's study works to break down distinctions between a medical model of disability and its alternatives - her reading of medical and educational responses to childhood disability is that twentieth-century responses lay somewhere between medical and social models. Nurses and teachers worked through a lens of "educability," recognizing the reality of medical treatments (as they were agreed upon at the time) but also seeing disabled children as individuals who were more than the sum of their impairments. Commend offers a welcome and timely alternative to stark divisions between models of disability - these models can be useful in developing the right answers to ask but can hold us back in developing answers that bear resemblance to social and cultural complexity. ${ }^{13}$

Tanya Titchkosky has argued that disability is not a "thing" in itself, but a process of fusing the "body-object" with the "body-subject" in targeted ways. If "impairment" is a reference to the body-object, then "disability" is a reference to the body-subject - an

\footnotetext{
12 "Deaf Gain" refers to the cultural and individual gains from being deaf. As a way of decentering hearing loss as a primary focus of what it means to "be deaf," it joins "deafhood" in an expanding family of cultural terms that deaf scholars and artists have developed in order to challenge the historical stigma of deafness.

${ }^{13}$ Susanne Commend, "Au secours des petits infirmes: Les enfants handicapés physiques au Quebéc entre charité et exclusion, 1920-1990,” PhD thesis, Université de Montréal, 2018.
} 
embodied difference that collapses both so that disabled people are and are defined by their bodies. ${ }^{14}$ The generation of scholarship that has arisen with "embodiment theory" in the late 1990s and early 2000s has forged a wide scholarly emphasis on how bodies are constituted by discourses, at least in the eyes of observers or interlocutors. Embodiment theory has influenced fields well outside of Anthropology in the ensuing decades. Cognitive Psychologist Rebecca Fincher-Kiefer has recently argued that "embodied cognition" explains how knowledge develops bodies physically as well, given that mental and physical development takes place along trails blazed through neural paths already established within the brain. ${ }^{15}$ Embodiment theory has the advantage of collapsing a mind-body dualism and recognizing that different types of discrimination and oppression (based on race, bodily difference, class, or gender) are more intractable than pluralism, or liberal theory, would have us believe. The growth of scholarly and political emphasis on terms like "disabled bodies" and "black bodies" in the past ten years has honoured the contributions of embodiment theory and to commitments to expand the possibilities of ending various oppressions beyond simple publicity and reason. Oppressions have also been interpreted as a fundamental process of "dehumanization" in recent left-leaning political rhetoric, and calls for recognition as "human beings" have characterized many social justice movements. These embodied differences lead to practiced and "lived" differences that form borders around those outside of the realm of "normal bodies," denying them basic humanity. Oppression does not only end, in other words, because of publicity campaigns or shining examples of success from marginalized groups. Baynton's

\footnotetext{
${ }^{14}$ Tanya Titchkosky, Reading and Writing Disability Differently: The Textured Life of Embodiment (Toronto: University of Toronto Press, 2007), 12-13.

${ }^{15}$ Rebecca Fincher-Kiefer, How the Body Shapes Knowledge: Empirical Support for Embodied Cognition (Washington D.C.: American Psychological Association, 2019).
} 
argument - that disability discourse helped smooth the contradictions in liberalism - is incomplete, then.

This dissertation eschews this embodied perspective, and will focus on deaf Canadians as a linguistic minority, whether they were signers or oral deaf. I come at the issue of deaf exclusion and inclusion in the politics that governed deaf people's lives and freedoms from a more idealistic standpoint. Discourse does, indeed, hold a great deal of power in the construction of the material and cultural world. Yet in order to focus on deaf politics and deaf education as political and cultural phenomena, I feel it is necessary for me to attend to contingency and events as much as to discourse. I am also not sure that deaf people were always "denied humanity" during the time under study. Simi Linton has made the point that one key difference between "Disability Studies" and interventionist fields is that while the latter theorizes through a medical model framework, the former seeks to theorize "the significance of human variation."16 Those who represent key differences from a median able, male, white body are clearly human, but are often denied the theoretical benefits of humanness in an idealized liberal framework. Instead of being "non-human," those oppressed or socially diminished for their difference point to the unserious nature of a great deal of liberal freedoms as they have been theorized. Instead of looking to "disability" to make meaning of what constitutes a human, this project seeks to look to "disability" to draw a more representative picture of a form of politics that has been lionized as a palace that everyone will eventually be admitted to. I do not reject the language of embodiment, therefore, but I am theorizing about political and social inclusion, more than hard borders around bodily difference. The term

\footnotetext{
${ }^{16}$ Simi Linton, “Disability Studies and Not Disability Studies," Disability and Society 13, no.4 (1998): 33.
} 
"humanitarian" is preferential to "charity" because it is flexible enough to describe this complicated, sometimes groundless, process.

This criticism of liberalism - as a phantasm of liberation - does necessitate that I wrestle with Foucauldian notions of social control through internalized dominant discourses. Shelley Tremain argues that the impairment/disability distinction on which the social model rests is itself a product of bio-power and is impossible to untangle from the government of disability itself. Impairment, therefore, "has remained untheorized."17 The construction of impairment, in the context of liberal governmentality, "was disability all along," Tremain writes, arguing that the construction and regulation of particular types of bodies is where oppression lies, not in a simple inability to accommodate impairments, as the social model holds. The distinction between impairment and disability is not a central theme of this study, nor is the Foucauldian notion of bio-power. Foucault's sketches of what he means by bio-power, however, do closely approximate Mann's idea of "crystallizations" and are useful in an exploration of how public attitudes toward deafness and diversity can be influenced by elite and institutional constructions. He argues that the state normalizes through bio-power, a "power whose task is to take charge of life needs continuous regulatory and corrective mechanisms...the law operates more and more as a norm...the juridical institution is increasingly incorporated into a continuum of apparatuses." ${ }^{18}$

\footnotetext{
${ }^{17}$ Shelley Tremain, "On the Government of Disability," Social Theory and Practice 27, no. 4 (October 2001): 621.

${ }^{18}$ Michel Foucault, The History of Sexuality, Vol 1: An Introduction, trans. Robert Hurley (New York: Random House, 1978), 144. A key difference between Mann and Foucault is that Mann's crystallization model relies far more on contingency and less on a static top-down concentration of power, or the permeability of power that Foucault asserts.
} 
I have chosen to conceptualize state formation through Mann's notion of crystallization over Foucault's bio-power because it is less totalizing and allows more for both activist influence on the state as well as the phenomenon of a forming state choosing to downplay its own jurisdictional power, as happened on the Prairies throughout this study. ${ }^{19}$ The state, in short, did not create hearing attitudes toward deaf people, but worked to manage the alternately interventionist and laissez-faire nature of the hearing public's humanitarian, and its sometimes outright hateful, outlook. Resistances to diversity, simply put, are harnessed and used by the liberal state, but certainly predate it and helped to inform liberalisms themselves.

\subsection{Sources and Methodology}

Archival research for this project began in 2014 in Winnipeg, in the summer before my Master's program at the University of Calgary. Intermittently over the next five years, I consulted provincial archives in Winnipeg, Edmonton, and Regina, the MSD Deaf Heritage Room in Winnipeg, Legislative Reading Rooms in Winnipeg and Edmonton, and University Archives in Edmonton. With the exception of the Admission Application box and Student Attendance Record books, working in these archives meant looking through large collections of correspondence and reports to find single sources especially for the MSD records in the Public Works files at the Provincial Archives of Manitoba. Despite the drawbacks (time, labour), it was important for me to see the ecosystem in which these documents "lived" and were grouped by past archivists. In looking through boxes of documents for the few that referenced deaf education in Manitoba, I began to understand what government officials meant by the term

\footnotetext{
${ }^{19}$ Foucault, in his sketches outlining biopower, allows for veins of resistance to governmentality as well, though his explanation of how this might be achieved was scant.
} 
"dependent children." Requisition forms and invoices for firewood, school supplies, laundry services, and other necessities of nineteenth-century institutions were shared by the Ninette Insane Asylum, the Home for Incurable Children, and the Manitoba School for the Deaf. Notices of murders committed by inmates at the Ninette Asylum or violence at the Manitoba Penitentiary were, until the late 1890 s, found in folders next to all of the procedural banalities of the asylums and services overseen by Public Works - job applications, inquiries into the whereabouts of loved ones, demands for the province to build local roads and bridges, as well as a tangible record of patronage as the bedrock of the early state formation process. When deaf activists and their hearing allies began to ask for a move from Public Works to Education before this was accomplished in 1914, it was primarily for this reason - they wanted the public to understand that the MSD was a school like any other, not an asylum.

The fact that these application and school records deal with children's personal and medical histories necessitated that I enter into a research agreement with the Manitoba Department of Education. In honouring that agreement, I have devised and used pseudonyms for children who I located in these archives. Beside these pseudonyms in accompanying footnotes, I have included the corresponding application numbers that another researcher would find in these files at the Provincial Archives of Manitoba, in order to allow an authorized researcher to link individuals to the assertions and examples in this research.

The records in Saskatchewan were more differentiated, like the twentieth-century Public Works files in Manitoba. The papers of several Ministers of Education, including Samuel Latta and W.M. Martin, offer some correspondence on the issue before the 1920s, 
including wrangling over whether Saskatchewan's compulsory schooling law of 1917 applied to deaf children, and several orders-in-council with attached memos. The Provincial Archives of Saskatchewan are strong on interprovincial negotiations over shared responsibility for "dependent classes," as well as the effect of two disruptive elections in Manitoba on these frameworks - those of Tobias Norris in 1915 and John Bracken in 1922. This correspondence, interprovincial and intra-provincial, show a Saskatchewan government that publicly messaged little, and created little in the way of statute, over deaf education before the WCAD campaign that is discussed in Chapter Seven was begun. These successive Liberal governments spent much of the 1920s developing ad-hoc solutions to the deaf education issue, failing to study the issue in depth, and often dealing with individual cases rather than moving responsibility for deaf education fully to Education and away from the Bureau of Child Protection. Governments tabled the issue for years until the 1928 Bill and the 1931 opening of the SSD. Frustratingly, the Saskatchewan Bureau of Child Protection did not archive the records of its agents who found deaf, intellectually disabled, and blind children to try to introduce them into the province's school system, as it was.

The archival situation in Alberta was the most frustrating to deal with. The Provincial Archives in Edmonton really only begin to deal with the establishment of deaf education in the years immediately preceding the establishment of the Alberta School for the Deaf in 1955. I have pieced together most of what I have contributed to the historical literature on Alberta using correspondence received in Winnipeg and Regina. This accounts for the heavy Saskatchewan bent in this study. An exception to this is the R.J.D. Williams Papers and Western Canadian Association of the Deaf Papers at the University 
of Alberta Archives, both of which were instrumental to the success of this study. The Williams papers, in particular, gave a nuanced inside view of the WCAD as a political organization and allowed me to expand my analysis of the association beyond its side that faced the provincial government and media. Williams also kept up correspondence with parents of deaf children, allowing me to contextualize the fears and questions faced by men and women about to send their children away for at least nine months.

This project really began to take shape in May of 2018, when I arrived in Winnipeg to see, in particular, one box of Admission Applications that covered the time period in my study. I planned to go over these quickly and move on to the record books that I had also gone through the Manitoba Freedom of Information and Protection of Privacy Act (FIPPA) process to obtain access to - a process that forbid me from copying or photographing forms. Instead, I spent six days transcribing what I could via pencil and paper of 398 application files from Alberta, Saskatchewan, Yukon Territory, and British Columbia, getting an endlessly complex and bewildering picture of domestic lives, bureaucratic categories of disability, and children's interests. Each evening, my hand closed in a semi-permanent claw, I went back to my University of Winnipeg dorm room and tried to make sense of what I had seen that day, and what I should have been taking note of. Each application is three to four pages long and features questions about a prospective student's medical history, heredity, economic circumstances, educational history, abilities, and interests. These questions result in a document that straddles the divide between Victorian biographical case study and early twentieth-century eugenic case studies. While both offer the logic of inevitability and destiny, the former was far 
more amenable to what we would now call accommodation. ${ }^{20}$ These did change over time, from a document under Duncan McDermid that strove to find methods of possible accommodation for prospective students with bodily or intellectual difference to documents under his son Howard that sought to prevent these same students from attending the school. These applications are essential to most chapters in the dissertation. Many of the questions I sought to answer began their journey to analysis here.

The application forms also allow for the quantitative analysis that is undertaken in the study, though it is, at its centre, a qualitative study. There are advantages to having a large sample size over forty years, though the explosion of applications from Alberta and Saskatchewan during and after the First World War makes direct trend comparisons difficult. Still, this study offers an opportunity to test some formative theses about the early twentieth century in disability history - the rise of a medical model by the end of the First World War, the growing stigma of physical and mental traits targeted by eugenicists by the 1910s, and the demographic impacts of the War and influenza pandemic on Canadian society in the 1920s. This study will evaluate these, at least with respect to MSD applications from Prairie Canada outside of Manitoba.

Silent Echo (1892-1914) and The Echo (1914-1940) were also indispensable sources. I found the first eight years at the MSD itself, and the remaining thirty or so at the Legislative Reading Room in Winnipeg. This school paper, written both by students and teachers, and deaf-edited for most of its print years, gives deep insight into some aspects of Prairie deaf life and politics, while it eschews description of others. The paper

\footnotetext{
${ }^{20}$ For an example of an application, see Appendix 1. The differences between how Duncan and Howard McDermid treated the issue of "feeble-minded" children will form the bulk of the analysis in Chapter Six.
} 
itself was a source for deaf people, and later deaf organizations, to use to build community, politics, and leisure. (Silent) Echo allowed me to trace connections between individuals, prairie communities, and the growing organizational presence of deaf Western Canadians. It was also a clearing house for transnational ideas and tactics that flowed across the Canadian-American border through deaf publications and personal travel. The paper, while deaf-edited for much of its print run, was not an unvarnished view of deaf community ideas, however. First - deaf people in Western Canada were like any other discernible group in that they shared different ideas and at times came into conflict over them. Secondly - even though deaf teacher J.R. Cook co-edited from 1892 to around 1900 and then edited for the next eighteen years, we cannot assume that his ideas were the community's. While The Echo is a wonderful source for trying to capture these ideas, it is important to weigh the unified public face of the WCAD with the more divided internal voice that we can see at times in Williams' papers.

Like any study, this dissertation reflects methodological choices. It relies heavily on the use of correspondence and publications from deaf, government, and media sources. It does not wrestle with the photographic evidence offered in The Echo and the WCAD papers in great detail. This is despite the fact that there are ample published photographs in the paper after 1900. I offer limited analysis when the photographs speak to the issue of maintaining student connections to home in Alberta or Saskatchewan, but for the most part, I feel that this would be a wonderful resource in a study of life at the school itself, or messaging from the Manitoba government, but this is not that study. It makes use of Annual Reports from the Departments of Public Works of Manitoba, Education in Alberta, and the Bureau of Child Protection in Saskatchewan and Alberta - yet analyses 
them more as products of what the Ministers of those departments wanted the public to see, and sees them as more obfuscatory than illuminating. Annual Reports need to be read against the grain, or analysed as crystallizations of power relations.

Having access to two large sources like almost every issue of (Silent) Echo and the application records of every student who applied from Alberta and Saskatchewan allowed me to undertake some quantitative analysis and feel as confident as possible in my characterizations of change or stasis over time. Upon my return from the archives in June of 2018, I created spreadsheets separating students into groupings dependent upon which attributes I wanted to quantify - religion, economic situation, settler or Indigenous status, whether they had been educated before the MSD or not, and other categories. This allowed me to create much of the quantitative data contained in the study, from numbers

of applications per year and the settlements from which these were sent to Winnipeg from, to who filled out application forms if parents did not. This data, and the graphs that I have produced from this data, is important to the study, but less important than the correspondence and (Silent) Echo in forging arguments about how governments responded to the need for deaf education, and how deaf people pressured them to work on the issue.

\subsection{Privileges and Choices}

My reliance on provincial archives, and my access to restricted material as a doctoral student, can be seen to stand in for the bevy of privileges I bring to this project. My Vanier funding and status as a mature student allowed me to travel extensively, and my student status meant that I could access documents that most members of the deaf 
community in Regina, Winnipeg, and Edmonton could not without difficulty. Access to several of my key sources were governed either by the FIPPA process in Manitoba, or special permissions from Saskatchewan that I applied for in an academic capacity. Over years of study, the irony of this was never lost on me, and I have tried, and will continue to try, to engage with deaf communities both in Ontario and the West. A project to assist the Regina Association of the Deaf in compiling videographic history through sign interviews with elders was in the making, but has been delayed first due to scheduling difficulties during the school year and the COVID-19 crisis in the spring and summer of 2020. Assisting the RAD in this project, and important archival work, is something that I will continue to seek to undertake in order to give something back to a Western deaf community that has made my project, and grant success, possible.

One of the reasons for the silences around deaf history in provincial archives is a feeling among some deaf in Western Canada that the state will be disinterested, or mishandle and bury, documents and records that help reconstruct it. This means that private records exist that have not been deposited at provincial archives by deaf families who fear they would be discarded or disappear. Alberta's records are a good example of this - some in Alberta's deaf community argue that the sex abuse scandals at the ASD in the 1980s led to the destruction of Department of Education documents dealing with the school. Documents archived in Edmonton are sparser than they should be, at least in comparison to Manitoba and Saskatchewan. I cannot confirm this, but it gives us a glimpse into how many deaf elders and community members have come to feel about provincial governments controlling documents dealing with deaf history. The closing of the Saskatchewan School for the Deaf has left a space in the Saskatchewan community 
that is only partially filled with annual reunions of SSD alumni. Saskatchewan activists continue to argue against mainstreaming in schools and now look to either Winnipeg or Edmonton for the opportunity to have their children educated with deaf peers. ${ }^{21}$ Amidst these enduring problems faced by Western deaf people and communities, my ability to waltz into archives and do this work - based on academic rather than cultural criteria, remains a lingering source of regret for me.

Though I eschew embodied perspectives in favour of pointing to political ideas and discourses, I recognize that I follow in a long line of scholars who identify as nondisabled, white, and male. It seems easy for me to brush aside huge swaths of scholarship that deal with social responses to "problematic bodies," as I have an outwardly-appearing "normal" body. It is not easy, and I am mindful of these choices. I see my study as one that needs to be followed with different theoretical perspectives and positionalities, and look forward to the day when new studies of deaf history are undertaken by deaf scholars. I chose my more ideational approach because it fits my source base well, it helps to explain problems around historical access to deaf education in Western Canada, and allows me to situate my research in emerging Canadian debates around erasing barriers between liberal and colonial histories.

My hearing privilege also doubles as a handicap on my perspective. As Kusters, Henner, Murray, and De Meulder have made clear in their articles about deaf scholarship and deaf epistemology over the past decade, deaf scholars within local and transnational signing communities lay some claim to a familiarity with ontology that hearing,

\footnotetext{
21 "Advocates Say Lack of Sign Language in Saskatchewan Schools a 'Crisis," The Saskatoon Star Phoenix, November 6, 2019.
} 
beginning-signers like myself cannot. The labour of those who "make understanding happen," in Friedner's words, is deaf labour, and it is difficult for hearing people to truly couple that process with the community-making of deaf people themselves. ${ }^{22}$ What is inextricable for many signing deaf people can be revelatory for hearing people in retrospect. In some ways, I found myself naming a distinction between deaf and hearing conceptions of state provision - rights vs. humanitarian - that is helpful for explaining past processes that may seem obvious to deaf scholars.

\subsection{Key Contributions of this Study}

This dissertation offers a framework through which to understand the apathy of hearing people to deaf issues, namely "humanitarianism." Conceptually, the assignation of "humanitarian" values to hearing attitudes toward state provision and participation in deaf-hearing relations is a powerful tool for understanding hearing indifference. This dissertation posits a deaf community formation process that is difficult to extricate from hearing apathy and paternalism, and I will argue throughout that "humanitarianism" is a term that offers a greater conceptual flexibility than other terms, like "charity," "paternalism," and "oppression," which have limited applications that can fail to capture the combination of pity, concern, and dismissiveness that I see in hearing attitudes toward deaf people in this study's sources. In addition to producing a geographically formative study in deaf education, I see a contribution of this study to Canadian history and North American deaf history as being this conceptualization of a hearing/humanitarian and

\footnotetext{
${ }^{22}$ Friedner, "Understanding and Not-Understanding: What Do Epistemologies and Ontolologies Do in Deaf Worlds?" Sign Language Studies 16, no. 2 (Winter 2016): 184-203.
} 
deaf/rights split within the larger liberal hegemonic order that emerged in mid-nineteenth century Canada and declined in the 1930s.

As I considered in the Introduction, Canadian historians have developed models of state formation that have accounted for institutions under provincial jurisdiction after 1867, like education, healthcare, and relief. These clean lines, however, are challenged on two axes upon more concerted study: geography and levels of perceived "dependency." Manitoba and the NWT did not settle their borders until 1905, and Manitoba did not expand northward to the $60^{\text {th }}$ Parallel until 1912. More importantly, even within defined geographically bound and recognized borders, "dependent" populations could often not always expect to receive entitlement to similar services as those deemed "independent." All three Prairie provinces, as we will see, considered the sharing of the "burden" for deaf, blind, and intellectually disabled children, as well as those labelled with mental illness, after the federal government stated uncategorically that these services fell under territorial jurisdiction in $1892 .{ }^{23}$ Between 1890 and 1931, the process of provinces taking ownership of programs and institutions for "dependent" people was slowly advancing but was not complete until 1965. The confusion of Saskatchewan politicians about the province's own compulsory laws shows that these rural ill-defined borderlands were a borderland of jurisdiction and interest. Put simply, theorizing about why deaf education did not emerge takes us out of functional state formation explanations and into the realms of disability and contingent politics.

${ }^{23}$ See Chapter Three. 
Michael Mann maintains that societies are not systems, but the products of structural currents and the ripples of contingent events. ${ }^{24}$ If we consider the four principal state formation theories identified by Robert Higgs - modernization theory, public goods theory, welfare state theory, and political redistribution theory - we can see just how difficult it can be to explain how deaf education foundered as it did in rural, and some urban, areas of Saskatchewan and Alberta before $1955 .{ }^{25}$ If states grow to meet growing complexity, as modernization theory holds, then deaf education should have become a provincial priority before the 1930s. If public goods theory holds true, meaning that states grow to provide necessary services that are in the private interest of no investor, the same likely holds true. Welfare state theory, which posits that the state expands to protect citizenry from the undermining of charity by market forces, is hardly applicable here, but would have worked to pressure governments earlier, as would have political redistribution theory, which posits that deaf education could have been demanded by a population that had reached the height of pre-1947 suffrage by the late 1910s. If deaf education cannot be explained in functional terms, then perhaps the more realistic and contingent models presented by Mann may help. This study will posit that the First World War was a large driver of admissions to the MSD from Alberta and Saskatchewan, especially given that population growth had exploded before 1914 but applications had not. It will also explain the founding of the Saskatchewan School for the Deaf not as a natural outgrowth of state complexity and increased population, but out of the politics of committed deaf activists and their hearing allies who activated ideas around state

\footnotetext{
${ }^{24}$ Michael Mann, The Sources of Social Power, Volume 3: Global Empires and Revolution, 1890-1945 (New York: Cambridge University Press, 2012), 3-4.

${ }^{25}$ Robert Higgs, Crisis and Leviathan: Critical Episodes in the Growth of American Government (New York: Oxford University Press, 1987).
} 
formation in a dialogue with the state and public. Seeing the late rise of the bureaucracy around deaf education in the former Northwest Territories as a crystallization helps to account for both its late development at its precarious hold in Saskatchewan after the 1980s and Manitoba after 1940.

The preceding paragraphs point to two important contributions of this study: it contributes to central debates about Canadian state formation by arguing that mere pluralistic and functional explanations cannot be taken for granted when disabled or otherwise marginalized people are the "recipients" of government services, and it argues that discrimination based on ability, or "ableism," has a discernible historical impact on disabled people and often resulted in a widening gap between able and disabled bodies during key periods of state formation. ${ }^{26}$ While this study uses the framing of humanitarian attitudes instead of the more unidimensional "ableism" or "audism," public and government perceptions that provinces could bide time for deaf and blind children, but not others, is certainly discrimination. Canadian studies of state formation, whether in health, education, incarceration, or other fields, have reflected this contingent nature and not a deterministic one, yet national theorizing about the state has not kept pace with this complexity and remains wedded to Marxist political economy. ${ }^{27}$ While Bruce Curtis has written about the birth of the Census and the rise of education in Quebec in more theoretically flexible terms by using a Foucauldian/Gramscian hybrid, the ideological drive to create regimes of governmentality represented by those studies was still

\footnotetext{
${ }^{26}$ Jameel Hampton makes a similar argument about the postwar welfare state in Britain. See "Discovering Disability: The General Classes of Disabled People and the Classic Welfare State, 1948-1964," Historian 75, no. 1 (2013): 69-93.

${ }^{27}$ For the best example of this type of political economic work see Leo Panich, The Canadian State: Political Economy and Political Power (Toronto: University of Toronto Press, 1977). See also Curtis, Ruling By Schooling Quebec and Curtis, The Politics of Population.
} 
essentially top-down and inexorable. Marxist theorists paint the state as "captured" by capital and reproducing capitalistic relations, and more refined Marxist theorists see the nation state as a precursor to the development of capitalism, and state formation as a process of cultural revolution, ${ }^{28}$ bringing a hybrid of Marx and Emile Durkheim to the table. ${ }^{29}$ Foucauldian scholars paint the space between the state and civil society as porous, and argue that this distinction can be less important in a totalizing liberal system. Mann's approach shares an anti-pluralism with Marxist approaches, as well as an antifunctionalism with Gramscian and Foucauldian approaches. His approach is more a model for working than a theory, per se, and is sophisticated enough to account for contingency and change. It also allows for leaps of scale - although it largely examines macro-level sociological phenomenon, it sees these outcomes as resulting from struggles between ideological, economic, military, and political power at several at national, subnational, and local levels. My use of Mann is a unique contribution of this study to historicising state formation in Canada. ${ }^{30}$

This study also contributes to a growing field of research that frames disabled people as political agents. Many of these studies focus on the 1960s to the 1980s, when disability rights movements sprung up amidst a larger movement for human and civil rights in North America. ${ }^{31}$ This study points to disability activism and deaf political agency in the early twentieth century in Saskatchewan, and argues that the earlier contributions of disabled and deaf activists to political life have largely been sidelined

\footnotetext{
${ }^{28}$ See Corrigan and Sayer, The Great Arch.

${ }^{29}$ Emile Durkheim argued that nation states should be seen as sites of common religious and ideological purpose, and that when these forces weakened, states formed to fulfill these earlier centripetal functions. Emile Durkheim, The Elementary Forms of Religious Life, trans. Joseph Ward Swain, (London: George Allen and Unwin, 1964 [1915]).

${ }^{30}$ Though Heaman also uses Mann, her state formation work is more of a synthesis than a situated study. See Heaman, The State in Canada.

${ }^{31}$ See Galer, Working Towards Equity.
} 
because their achievements were spotty, and they were less public in their protest and advocacy. ${ }^{32}$ These facts do not mean that the activities undertaken by the Western Canadian Association for the Deaf in the 1920s and 30s were apolitical. The generation of deaf students who revolted against oralism in schools and worked to achieve deaf leadership in deaf educational positions in the 1970s and 80s were building on the work of an earlier generation of activists in Western Canada, though they used more public tactics developed in the postwar era across rights movements for peace, an end to racial segregation, and gay rights.

This study makes three primary contributions to deaf history. It deepens the burgeoning study of transnational links in North America, and establishes that political and intellectual connections to the United States had a deep impact on Canadian deaf people and groups. It also contributes to the history of deaf families and deaf people in hearing families. Most importantly, it contributes to a small field of studies that consider deafness in rural settings, mainly through following a few prominent deaf families and figures through decades of prairie history. Most studies on deaf individuals and organizations have focussed on urban deaf publics, despite the fact that most deaf Americans and Canadians were farmers or farm labourers. A key source that allows me to study rural deaf, which is so hard in other contexts because of a lack of documents, are the MSD application files. Like Sara Spike's, my study attempts to consider disability beyond institutional walls - a pursuit that is often difficult due to the lack of sources

\footnotetext{
${ }^{32}$ See Sandy Barron, "The Absolute Indifference of the Majority": The Western Canadian Association of the Deaf and the Establishment of Deaf Education in Saskatchewan, 1923-1931, The Canadian Historical Review, forthcoming.
} 
produced by disabled people themselves. I still, however, principally use institutional sources to do this.

This study also contributes to disability history in disruptive ways. Primarily, I argue that the discipline itself has emerged as the project of shedding light on the emotional, historical, and oppressive relations that become visible as we look at sources using disability as a new theoretical lens. This has resulted in numerous studies of outstanding quality and depth in the emerging field. It has also hampered our ability to reconnoitre the conceptual spaces between different experiences of disability that emerge from different impairments, geography, class, race, and gender. This study looks at how the work done by disability in much of the rhetoric used by deaf Western Canadians and their hearing allies contributed to the marginalization of people identified as intellectually disabled. It also frames how deaf education, as an emerging educational movement, worked to further the settler colonial project - often with deaf people's input and support.

I identify settler deaf support for the colonial project and the segregation of intellectually disabled-labelled people not to criticize the deaf community and its history, but to try to provide one contribution to making deaf and disability history as diverse and complex as possible.

\subsection{Conclusion}

Liberal governance has emphasized the self-governance of citizens, as well as the eventual inclusion of all who have shown to be capable of this benchmark. The experience of deaf Albertans and Saskatchewanians shows that deafness and disability were stifling stumbling blocks toward true political inclusion, and that demonstrating 
educability and self-governance were often not enough for deaf communities to command equal claim to state resources and expertise. Settler deaf youth, however, were still conceivably on the path to imagined liberal citizenship, unlike Indigenous deaf youth, who were often defined jurisdictionally and culturally outside of the purview of provincial deaf education efforts.

This dissertation is, overall, a work of political history. By "political history," I use Colin Grittner's expansive definition that builds upon former efforts by Canadian scholars to expand definitions of "politics" and "political." Grittner writes that "new political history indicates a desire to move beyond government walls and understand political behaviour outside of elite circles... reaching beyond the legislature to account for state formation...(and) by revealing the political dimensions of cultural categories." 33 Part of this expansion of the conception of "political" is to usher deaf people in as individuals and as interest groups themselves. In that way, though this thesis is a work in what is often called "the new political history," it is also informed deeply by deaf history and disability studies. It is, also, written and researched by a hearing man. I can only trust that I have done the work and analysis to have this study be worthy of consideration from deaf communities and individuals.

\footnotetext{
${ }^{33}$ Grittner, "Greater Expectations," 603.
} 


\section{Chapter Three: Early Deaf Education, Settler Colonialism, and the Establishment of Western Canadian Internal Borders, 1880-1905}

"Circumstances (which with some gentlemen pass for nothing) give in reality to every political principle its distinguishing colour, and discriminating effect."

\section{Edmund Burke ${ }^{1}$}

"I turned the key and I broke it off, and I crossed the Rubicon."

$$
\text { Bob Dylan }{ }^{2}
$$

\subsection{Introduction}

Settlement and colonialism have transformed the physical and cultural make-up of Western Canada. Agriculture, surveying, and the extirpation of bison herds have rendered Prairie grasses extinct, produced a tiled pattern that makes the Prairie look like a homemade chessboard, and set aside small areas for First Nations governance to at first be stamped out. Canadian historical writing has also transformed the Prairies by entrenching formative historical narratives that have erased Indigenous agency and culture, reproducing reductive, unmodern views of Indigenous people and life. The process of colonial transformation has affected most areas of physical and intellectual life, colonizing not only Indigenous bodies and minds, but also settler minds through the process of making colonialism and whiteness invisible. Deaf education is only a small part of this. This small area of study, however, can help us see the colonial process clearly, and can shed light on how a colonial outlook shapes a myriad of exceptions from liberal individualism. This dissertation outlines the settler deaf journey toward liberal individuality in the minds of hearing Canadians, but it also brings attention to the active

\footnotetext{
${ }^{1}$ Edmund Burke, Reflections on the Revolution in France (New York: Oxford University Press, 2009 [1790]), 8 .

${ }^{2}$ Bob Dylan, "Crossing the Rubicon," Rough and Ready Ways (Columbia Records, 2020).
} 
exclusion of Indigenous deaf from that process. The humanitarian impulse that ensnared many deaf youth and adults in a precarious status with the state included oppressions and paternalism, but on a whole different order than settler humanitarianism faced by Indigenous people.

This chapter traces one aspect of Canadian colonialism in the Northwest Territories from 1880 to 1905 : the development of institutions, practices, and political beliefs that rose in response to the arrival of deaf settlers. The slow and incomplete progress made toward developing deaf education in the NWT before 1905 runs in contrast to the near-total exclusion of Indigenous deaf children from settler institutions due to a racially segregated educational system and the establishment of the only firm jurisdictional border established in the nineteenth-century: the establishment of Indigenous people as "federal wards." I will argue that Western Canadian governments offered liberal individualism for white settlers but colonial subjugation for Indigenous people - showing that liberalism as a totalizing vision of human freedom reflected its opposite, namely colonial rule of others. I will then briefly outline the histories of Indigenous nations on the Prairies before the purchase of Rupert's Land by the Canadian Government in 1869, the history of Indigenous sign languages, the establishment of the Manitoba Institute for the Deaf and Dumb in 1889, and the few exceptions to the MIDD's rule of excluding Indigenous students. I will also spend time examining a campaign waged by Duncan McDermid, the Principal of the MIDD from 1890-1909, to extend deaf educational provision into the NWT. Together, these stories describe an increasing divergence between how the state reified settler and Indigenous crystallizations of liberalism, as the former transformed from a primarily individualistic strain toward a 
more collective liberalism that highlighted societal responsibility for ensuring

opportunity for as many citizens as possible, within the bounds of exclusion based on British subjecthood and, sometimes, disability.

\subsection{Liberalism, Colonialism, and Deaf Education}

The twenty-first century in Canadian historiography has seen the development of two influential and linked historiographical projects - Ian MacKay’s “liberal order framework" as well as a more concerted effort to see Canada as a "particular kind of national and colonial project." ${ }^{3}$ The first situates Canada as a liberal project rather than a sustained national polity based on a common identity and story, and the second argues that the Canadian state arose and developed in opposition to Indigenous polities, resulting in the active erasure of Indigenous lives, history, and occupancy. Liberalism and colonialism as Canadian projects are not distinct from one another, however, and the Lockean "social contract" has colonial caveats that can outweigh the gender, capacity, and racial caveats I have described in Chapter One. Liberalism and settler colonial culture denied to Indigenous peoples the property ownership, responsible forms of individual freedom, and claim to productivity that formed the basis for membership as a liberal subject. The expansion of deaf education into the areas now known as Alberta and Saskatchewan in the early twentieth-century crystalized in similar ways as other educational and social institutions, meaning that calls upon the state to offer new and compulsory forms of service that were seen as instrumental in the development of liberal individualism were not meant to extend to Indigenous people.

\footnotetext{
${ }^{3}$ Adele Perry, "Presidential Address: Starting with Water: Canada, Colonialism, and History at 2019," Journal of the Canadian Historical Association 30, no. 1 (2020): 20.
} 
Liberal democracy was, by the 1880 s, a broadly accepted practice and feature of the Canadian state. Canadian political cultures were liberal, but broadly so. Michel Ducharme, in his study of republicanism and constitutionalism in the early nineteencentury Canadas, argues that the defeat of republicanism in 1837-38 enshrined constitutionalism as the principal ideology of nineteenth-century liberalism. This model of liberalism, shared by Tories and Whigs alike by the 1840s, "fostered the emergence of a liberal order founded on the principles of liberty, equal rights, and property." ${ }^{4}$ While the equal rights protected under constitutionalism were initially civil liberties that protected propertied individuals from state overreach, by the late-nineteenth-century the rights of select groups of Canadians to some state provisions were beginning to draw the attention of liberals who turned their attention to social reform. Access to education was one of the first of these, as in the establishment of the Ontario Institute for the Deaf and Dumb in 1871 after a concerted outcry from parents of deaf children in that province who resented the burden of paying school taxes for hearing children while parents of hearing children contributed nothing to the educations of their children. ${ }^{5}$ An expansive notion of late nineteenth-century liberalism is central to the assertions of this study, and this chapter will trace the political cultures of those who advocated for the educational rights of deaf Western Canadians as being on the leading edge of liberalism's expansion into the realm of rights rather than simply the protection of private property and propertied individuals from government interference.

\footnotetext{
${ }^{4}$ Michel Ducharme, The Idea of Liberty: In Canada During the Age of Atlantic Revolutions, 1776-1838, trans. By Peter Feldstein, (Montreal and Kingston: McGill-Queen's University Press, 2014), 186.

${ }^{5}$ See, for example, J.B. McGann, "Sixth Annual Report of the Upper Canada Institution for the Deaf and Dumb and Blind for the Year 1864," (Toronto Reference Library, FILM F CIHM 37385), 7.
} 
Histories of Western settlement and political developments have traced the dominance of colonial settlement and the imposition of a liberal order on the West. Using Ian MacKay's proposed framework for a new understanding of Western settlement as an expansion of, above all, an individualistic liberalism rooted in the acquisition and protection of property, scholars of Western settlement have argued that non-British settlers were able to claim British subjecthood through the successful acquisition of the trappings of belonging in a liberal society - property ownership and the capacity to undertake liberal political thought and judgement. ${ }^{6}$ Eyford's study of Icelandic immigration traces a transformation of Icelanders from a carefully managed, and at one point quarantined, block of settlers who were overseen by Canadian officials as provisionally liberal subjects who needed to prove their membership in a liberal order. ${ }^{7}$ As Eyford makes plain, though, Indigenous Canadians faced a far more onerous and often impossible path to British subjecthood that offered little but the destruction of established cultural practices and ways of life.

Liberalism, though, is truly settler Canada's "view of itself," to repurpose Mann's criticism of pluralistic state formation theories. It cannot be separated from the colonial project. Recent scholarship has also highlighted Western settlement as a project of Indigenous displacement above all else. Work by Sarah Carter, Adele Perry, James Daschuk, Mary Jane Logan McCallum, and others has convincingly argued that, despite the differences between immigrant settlers from a cultural perspective, their eventual acquisition of a provisional white, liberal identity is indicative of the central tenet of

\footnotetext{
${ }^{6}$ Ian McKay, "The Liberal Order Framework: A Prospectus for a Reconnaissance of Canadian History," Canadian Historical Review 81 (2000): 617-45.

${ }^{7}$ Ryan Eyford, White Settler Reserve: New Iceland and the Colonization of the Canadian West (Vancouver: UBC Press, 2016).
} 
Western expansion - that of the establishment of a white settler polity in opposition to a displaceable yet also rhetorically and politically non-existent Indigenous polity on the Prairies. The establishment of Ukrainians, Icelanders, and other immigrant groups as liberal citizens was dependent on the displacement and marginalization of Indigenous peoples on the prairies through starvation as well as the establishment of systems of restriction and punishment around Indigenous movement, enculturation, and political participation. One principal historiographical development after settler and Indigenous Canadian historians took up a post-colonial perspective in the 2000s is highlighting the continued involvement of Indigenous people in Western political and social life, despite the historiographical banishment of Indigenous people from a modernist temporality based on the establishment of liberal political orders by most twentieth-century Canadian historians. McCallum's study of Indigenous women's employment likely makes this trenchant point best - and argues that the fundamental understanding of Western Canadian history as a narrative of settlement that preceded modernism is, in itself, a celebration of colonial displacement and dependent on the enforced invisibility of Indigenous politics, culture, and history. ${ }^{8}$

Settler political culture in Western Canada has too often been portrayed as a carbon copy of Central Canadian liberalism brought west by settlers from Ontario and Quebec. Adele Perry has argued that the underlying colonial ethos in British Columbia had resulted in a Western liberalism that looked not to the Canadian state as a colonial

\footnotetext{
${ }^{8}$ Mary Jane Logan McCallum, Indigenous Women, Work, and History: 1940-1980 (Winnipeg: University of Manitoba Press, 2014); Adele Perry, Colonial Relations: The Douglas-Connelly Family and the Nineteenth-Century Imperial World (Cambridge: Cambridge University Press, 2015); James Daschuk, Clearing the Plains: Disease, Politics of Starvation, and the Loss of Aboriginal Life (Regina: University of Regina Press, 2014); Sarah Carter, Imperial Plots: Women, Land, and the Spadework of British Imperialism on the Canadian Prairies (Winnipeg: University of Manitoba Press, 2016).
} 
power, but to a larger British white settler ethos that was only slowly subsumed by Central Canadian liberalism. As we have seen, historian L.H. Thomas argued that the political culture of the North West Territories looked to Central Canada as a colonial power through which to draw resources and political ideals before $1897 .{ }^{9}$ This study, as it looks at state formation in Alberta and Saskatchewan, maintains that institution-builders on the Prairies looked to the United States and Central Canada for models on which to build and maintain deaf education. Western Canada did produce a distinct political culture based in grievances over tariffs and railroad policy set by the federal governments, but most of those who fall under the lens of this study - deaf activists, education policy planners, and bureaucrats - balanced these perceived injustices with a need to first draw resources from, then emulate the practices of, Central Canada. An ethic of humanitarianism on the part of bureaucrats and educators allowed Alberta and Saskatchewan, however, to put off the development of compulsory and effective deaf education as we will see in this chapter.

Liberalism and colonialism may not be fundamentally separable, but the language and promise of nineteenth-century liberalism was central to defining who was within and without the liberal order. Some Canadian historians have criticized MacKay’s liberal order framework as too insensitive to changes and struggles within liberalism over the nineteenth-century itself. Jean-Marie Fecteau, in particular, argues that MacKay fails to see the revolutionary potential of early nineteenth-century liberalism, a movement that was less an ideological movement than a temporary, but reverberating, opening in some western societies that he characterizes as a "creative seesawing between freedom as a dream and a horizon and domination as the common denominator of societies in

\footnotetext{
${ }^{9}$ L.H. Thomas, The Struggle for Responsible Government.
} 
transition." ${ }^{10}$ At its most forceful, Fecteau's operationalization of liberalism eschews the imposition of state governmentality that Bruce Curtis' work exemplifies, but embraces liberalism as an ever transforming axis of social possibility that was enacted and practiced in institutions. The appeal of Fecteau's understanding of liberalism for this study is that it allows for a morphing liberal politics that features brief moments of social concern and transformation within a forty-year framework of deaf educational practice in Western Canada that largely shows more continuity that change, at least after 1889. In short, this study operationalizes a liberalism that highlighted personal rights to education, an expansive liberalism that was rhetorically available to certain disabled groups, especially young deaf Canadians. Transferring this rhetorical availability to actual practical availability is the story told by this study, which takes seriously Curtis' notion of state formation as partially about the expansion of administrative practice. Fecteau's conceptualization of liberal thought allows for a greater attention to the political cultures of those operating or influencing institutions and destabilizes the McKay model of a single liberal political culture rooted in the protection of property and individual rights alone.

Fecteau's operationalization of liberalism asserts that freedom and regulation arose at "roughly the same pace," and reached a point where the development of bourgeois liberalism could assert that the very freedom of the poor and convicted was still encapsulated by the powerful liberal notion of "choice." "The poor and convicted, a particularly powerful late nineteenth century liberalism demanded, had used their freedom poorly, and emergent institutions such as penitentiaries and work houses sought

\footnotetext{
${ }^{10}$ Jean-Marie Fecteau, The Pauper's Freedom: Crime and Poverty in Nineteenth-Century Quebec, Peter Feldstein, trans. (Montreal and Kingston: McGill-Queen's University Press, 2017 [2004]), 33.

${ }^{11}$ Fecteau, The Pauper's Freedom, 33-34.
} 
to reform these individuals into those who would use their freedom well. The implication of this model of late nineteenth century liberalism, though, is that many individuals were poor or marginalized for reasons that transcended choice - especially deaf and disabled people. Deaf adults and children did not choose to be deaf - and being deaf was largely considered to be a calamity in late-Victorian Canada, though perhaps less of a lifealtering experience as being blind. The extension of public deaf education and limited vocational education does not fit comfortably into the charitable or medical models of disability, but inhabits a discursive and political space made available by the liberal revolutions of the late eighteenth century. This phenomenon, at least in the late nineteenth-century, cannot be encapsulated solely through theoretical models of disability or social historical theses of social control or governmentality. It is a phenomenon subject to institutional practice and change, political cultures, publicity and deaf advocacy, and contingent events. It is not, therefore, a straight teleological arc toward betterment - it is a narrative that points toward a slow attainment of educational rights for deaf Western Canadians, one that was finally attained at a low point of deaf political and cultural power over sign language rights, the 1930s and 40s.

Deaf settlers and deaf children born into both deaf and hearing families were inculcated in the colonial project, as we will see. Those born into hearing families were also subject to a kind of provisional liberal membership, dependent on educational attainment, property ownership, and the development and practice of liberal political ideas. Deaf children born into deaf families also had access to provisional liberal citizenship, but at times this access could be stymied when deaf parents advocated for deaf-led educational access, as we will see in the struggle over the effort to establish a 
deaf local school for the children of deaf settlers in the Lipton area of Saskatchewan in 1909. ${ }^{12}$ During the period covered by this chapter, deaf settlers in the West were seen as burdens upon the state, though public opinion moved toward an educational solution to this burden, from earlier calls to ban deaf (im)migration to the West. The politics of deaf education traced by this chapter were practiced through letters, pamphlets, newspapers, and intergovernmental correspondence, and will be considered through these types of sources. These politics also operated along the lines of a settler-Indigenous divide, as Indigenous children were rarely considered for enrollment at the MIDD, even Indigenous children who lived on reserves within Manitoba. This chapter will also examine these restrictions on Indigenous deaf inclusion in education.

\subsection{Indigenous Sign Languages on the Prairies}

Distinct forms of signing proliferated on Indigenous trade routes from time immemorial, and are still found in Indigenous communities today. Prairie nations, extending from the Rocky Mountains to the Great Lakes, participated in vast trade networks with nations further to the South, East, and West through large annual gatherings in what is now Missouri and California. These networks served nations stretching from across the entirety of North America, and necessitated communication strategies to facilitate trade. While a system of trade jargon called Chinook was used on trade routes between Alaska and California, most trade communication was undertaken through a complex system of Indigenous sign languages. Sherley-Appel and Bonvillian

\footnotetext{
${ }^{12}$ This effort will be discussed in further detail in Chapter Four.
} 
have shown that Inuit were capable signers at the time of the 1576-77 Frobisher expeditions as well. ${ }^{13}$

Historical linguist Jeffrey Davis argues that signed languages termed “American Indian Sign Language" or "Native American Sign Language" in the United States and "Indigenous Sign Language" in Canada brought together "forty spoken language groups across twelve major language families." ${ }^{14}$ AISL/NASL is, however, an umbrella term for related Indigenous sign languages, of which Plains Indian Sign Language (PISL) is most pertinent to this study. In addition to consulting oral tradition and Indigenous elders, historical linguists who study Indigenous Sign Languages have had to resort to both "upstreaming" - looking to current ISL to infer historical uses and variability, and "sidestreaming" - using what is known about one dialect and inferring that a neighbouring dialect was similar. ${ }^{15}$ This makes some claims about ISL in specific places and times precarious.

Indigenous Sign Languages were used along trade routes, but were also the primary language for deaf Indigenous people. ${ }^{16}$ Davis argues that the preponderance of evidence shows that although a majority of Indigenous people did not sign, a large minority did, and that communication between deaf and hearing Indigenous community members was easier than the American or Canadian contemporary norm. A 1914 issue of The Echo provides some evidence for this. Re-publishing a piece on John Clark, a deaf

\footnotetext{
${ }^{13}$ Clara Sherley-Appel and John D. Bonvillian, "Manual Signs and Gestures of the Inuit of Baffin Island: Observations During the Three Voyages Led by Martin Frobisher," in Deaf Gain: Raising the Stakes for Human Diversity, H-Dirksen Bauman and Joseph Murray, eds., 159-181. (Minneapolis: University of Minnesota Press, 2014).

${ }^{14}$ Jeffery Davis, "Discourse Features of American Indian Sign Language (AISL)," in Discourse in Signed Languages, Cynthia Roy ed., 179-218. (Washington, D.C.: Gallaudet University Press, 2011), 179.

${ }^{15}$ For further explanation of side-streaming and upstreaming, as well as Indigenous trade routes, see Pekke Hamalainen, The Comanche Empire (New Haven: Yale University Press, 2009),

${ }^{16}$ Jeffrey Davis, Hand Talk: Sign Language Among American Indian Nations (New York: Cambridge University Press, 2010), 6.
} 
Montana Blackfoot man who was famous for his wood carvings, the paper marvelled at his multi-lingual status. Clark had been taught oral English, and was "likewise adept at the Universal Indian sign language and can carry on a conversation with the members of any tribe of American Indians. ${ }^{, 17}$ Residential schools in Canada and the United States contributed to the decline in use of PISL in the same genocidal manner as spoken Indigenous languages, though both have survived that process. It is, however, an endangered language. ${ }^{18}$

PISL also came under attack from oralists who also sought to eliminate sign languages as a whole. The existence of PISL seemed to confirm for oralists that sign languages were "primitive" vestiges of earlier stages of human history - what the early anthropologist E.B. Tylor called "survivals." "19 American and Canadian officials, then, worked to stamp out PISL alongside spoken Indigenous languages in the hope that Indigenous people would use English as a new lingua franca as they moved along the path to "citizenship." In this way, the suppression of Indigenous sign languages are linked with the rise of English-centric deaf education on the post-1869 Prairies, both in terms of written English and later spoken English. While sign language was a large part of deaf education on the Canadian Prairies until the 1920s, it is important that we see the "methods debate" between manualists and oralists as a small subset of larger patterns of linguistic erasure in the context of Canadian colonialism.

Indigenous nations on the northern Prairies included the Tsuut'ina, Assiniboine, Cree, Kainai, Piikani, and Siksika. These nations followed bison herds, and they managed bison hunts through their distinct cultural, political, and spiritual organizations. Niisitapi

\footnotetext{
${ }^{17}$ TE 22, no.9 (February 2, 1914), 4.

${ }^{18}$ Davis, Hand Talk, 15.

${ }^{19}$ Davis, Hand Talk, 68-69.
} 
(Blackfoot) groups, enjoyed some of the largest average height of any measured humans on Earth in nineteenth-century anthropological surveys, indicating a balanced diet rich in proteins over centuries. ${ }^{20}$ As waves of disease made their way across the Prairies with the initial traders employed by the Hudson's Bay Company and the North West Company, decimated nations began to recover from smallpox and other epidemics through elastic practices of establishing citizenship, with survivors banding together to form new communities. ${ }^{21}$ These nations, as they came into contact with Americans, Canadians, and British travellers and traders, developed diplomatic and military strategies to forge a western edge of what Michael Witgen calls "Native North America," a polity that emerged as a defense against colonial intrusion through the enforcement of Indigenous terms of trade and interaction. ${ }^{22}$

The first concerted American study and dictionary of "Indian Sign Language," however, was a product of the military suppression of Witgen's Native North America, or White's Middle Ground. ${ }^{23}$ W.P. Clark's The Indian Sign Language began as a report to U.S. Cavalry General Philip Sheridan in the wake of the military conquest of Western Indigenous nations. ${ }^{24}$ As Ted Binnema argues, nineteenth-century Indigenous nations integrated relations with American and Canadian colonizers into an already existing "complex networks of trade, warfare, and diplomacy about which Europeans may have

\footnotetext{
${ }^{20}$ George Colpitts, Pemmican Empire: Trade, Empire, and the Last Bison Hunts on the North American Plains (New York: Cambridge University Press, 2015) 21.

${ }^{21}$ Theodore Binnema, Common and Contested Ground: A Human and Environmental History of the Northwestern Plains (Norman: University of Oklahoma Press, 2001), 14.

${ }^{22}$ Michael Witgen, An Infinity of Nations: How the New World Shaped Early North America (Philadelphia: University of Pennsylvania Press, 2011).

${ }^{23}$ Richard White, The Middle Ground: Indians, Empires, and Republics in the Great Lakes Region, 16501815 (New York: Cambridge University Press, 1991.

${ }^{24}$ W.P. Clark, The Indian Sign Language (Philadelphia: L.R. Hamersly, 1885).
} 
had only fragmentary knowledge. ${ }^{, 25}$ Indigenous nations developed and shared intelligence about American and Canadian encroachment through, in part, PISL, so Sheridan's command saw it as essential to develop knowledge of PISL as an act of military and diplomatic intelligence. Though Clark wrote to Sheridan that his study sought to further the study of "Indian habits and customs," its primary purpose was to develop a detailed understanding of "war and peace signs. ${ }^{, 26}$ Clark was, after all, a Cavalry Lieutenant who had spent six years with Indigenous allies in the West. Clark's book offers a treatise on the origins of PISL, its connections to pictographic representations and evolutionary human development. It is, however, a thorough dictionary of PISL that was likely meant for use by U.S. Army officers in negotiations and occupation.

William Tompkins, who published a sourcebook and dictionary of PISL in 1929, had spent parts of his early adulthood learning Indigenous sign languages with different nations on the American Plains. His book was published for the use of the Boy Scouts, in the hope that a generation of American boys would learn and use PISL in order to further "world peace." 27

Tompkins explicitly used "disappearing Indian" tropes in order to explain the decline of PISL, which he seems to have thought he was preserving. The number of users of this "first American language" had declined from 110,000 in 1885 to "a very small percentage of this number" by the 1920s. Tompkins blamed the decline on "the inroads of modern education" and growing Indigenous fluency with English, which most could

\footnotetext{
${ }^{25}$ Theodore Binnema, “Allegiances and Interests: Niitsitapi (Blackfoot) Trade, Diplomacy, and Warfare, 1806-1831." Western History Quarterly 37, no. 3 (Autumn 2006): 328.

${ }^{26}$ Clark, Indian Sign Language, 3.

${ }^{27}$ William Tompkins, Indian Sign Languages (San Diego, Self-published, 1929), 10
} 
"talk sign." ${ }^{28}$ Tompkins was a defender of Indigenous sign who saw it as in great need of saving. By calling PISL "the first American language," he equated sign language with human antiquity.

Annelies Kusters has argued that historical research on deaf communities and sign languages have privileged the study of "deaf utopias" where extant records indicate that sign languages were used by both hearing and deaf people. A longstanding example of this is the public interest in the historical signing communities of Martha's Vineyard that thrived in the eighteenth and nineteenth-centuries. Kusters is critical of these perspectives, and encourages researchers to evaluate sign usage in more realistic ways. ${ }^{29}$ Following this, we must be careful to not overstate the fluidity of communication between Indigenous deaf and hearing people before colonialism. Extant records and oral histories suggest some level of what Joseph Murray calls "co-equality," though these records also make it apparent that Spanish, French, and Indigenous chroniclers rarely distinguished between hearing and deaf signers. Still, as Tompkins reports E.B. Tylor as writing, "the same signs serve as a medium of converse from Hudson Bay to the Gulf of Mexico."30

\subsection{The Groom Expedition, Deaf Immigrants, and Partisan Print}

Deaf immigration to Canada was only a small part of the increase in the number of deaf people in the country. It did, however, feature disproportionately in media discussions on deafness in Canada. Nineteenth-century statistics, still stabilizing by the end of the nineteenth-century, assured Canadian politicians that one-in-a-thousand Canadians were born deaf, and a greater number became deaf through childhood disease.

\footnotetext{
${ }^{28}$ Tompkins, Indian Sign Language, 8.

${ }^{29}$ Annelies Kusters, "Deaf Gain and Shared Signing Communities," in Deaf Gain: Raising the Stakes for Human Diversity, H-Dirksen L. Bauman and Joseph Murray, eds., 285-305. (Minneapolis: University of Minnesota Press, 2014).

${ }^{30}$ Tompkins, Indian Sign Languages, 95.
} 
Nineteenth-century commentators and educators were convinced that the number of deaf children would naturally increase with expected population growth, but that the country should seek to eliminate immigration of deaf and disabled settlers. These restrictions, passed federally in 1869 , were ineffective because of a lack of enforcement and clarity over jurisdiction between Britain and Canada on the issue.

English deaf evangelist and former teacher Jane Elizabeth Groom has been a central figure in the scant secondary literature on deaf migration to, and settlement in, North America. ${ }^{31}$ Vickrey Van Cleve and Crouch depicted Groom as a conservative figure, an acolyte of a charitable model of disability, and an antithesis to the story of John Jacob Flournoy, an American deaf leader who proposed a deaf-only state in the antebellum United States. ${ }^{32}$ Jennifer Esmail has portrayed Groom as a antecedent to social models of disability, due to Groom's insistent that deaf people were living in poverty in London not because of an inability to work, but because of discrimination by hearing Londoners. My picture of Groom is neither - she was a steadfast supporter of British colonial projects who sought to simply include deaf British subjects with those who experienced the "regenerative" cultural effects of colonial settlement.

In 1884 Groom organized two settlement expeditions to Western Canada. Groom had been fired from her teaching job after the Wilmot School in London adopted oralism, and she began to work as an evangelist in deaf communities in the city, especially with poor deaf families and individuals in the neighbourhood of Hackney. She raised funds from an unnamed wealthy benefactor in London, in order to organize an "Emigration

\footnotetext{
${ }^{31}$ Esmail, Reading Victorian Deafness, 156-157.

${ }^{32}$ John Vickrey Van Cleve and Barry Crouch, A Place of Their Own: Creating the Deaf Community in America. Washington, D.C.: Gallaudet University Press, 1989.
} 
Society for the Deaf and Dumb Poor," and brought a small group of deaf settlers to Winnipeg in the summer of 1884 . Groom was concerned with British antipathy toward deaf people and sign language, and argued, through a pamphlet published between her two expeditions, that poor deaf Londoners needed to seek out a farming life in Western Canada in order to both prove their economic worth and set an example for Britons that deaf people often experienced poverty because of social and economic oppression, not because of a lack of work ethic or ability. From this standpoint, Esmail's argument that Groom was a precursor to the social model of disability makes sense. "The sad cases of distress, of starvation even, among the deaf and dumb in London," pseudonymous author H.H. wrote in the 1884 pamphlet,

are experiences which are ever before us. It is not caused by the reason that the deaf mutes will not work, but it is that they can not obtain sufficient employment; they are not needed in the community, there is too much competition to cause them to be needed in London or in the great centres of labour. They cannot get work to do in most localities, and, in others, the pay is low because of their inability to compete successfully with those who are not deprived of their powers of speech or hearing. Amoungst themselves they can manage to eke out a miserable livelihood, only; and their wages average from sixteen shillings and sixpence to thirty shillings a-week, or, in rare cases, a little more than the sum last named. This, even in comparison with ordinary labourers' and artisans' pay is low; and the consequence is that they have much difficulty in keeping body and soul together; as regards their habitations and the means they have for overcoming their social disadvantages, the readers of these pages can imagine as well as if a lengthy description of the struggles and privations were given. ${ }^{33}$

Groom saw Western Canada and deaf emigration from urban Britain as the only conceivable way for deaf Britons to throw off hearing oppression. Her vision contrasted urbanity and rurality, as she argued that deaf Britons could reinvent themselves through working the soil and undertaking productive agricultural labour. ${ }^{34}$ As we will see,

\footnotetext{
${ }^{33}$ H.H. "A Future for the Deaf and Dumb in the Canadian North-West," Peel's Prairie Provinces (http://peel.library.ualberta.ca/bibliography/1240.html), 9. Accessed February 17, 2019.

${ }^{34}$ H.H. "A Future," 11.
} 
Groom's vision of agrarian renewal was not often shared by the settlers that she brought to Manitoba.

Groom requested that the Canadian government assent to the scheme by allowing the settlers to farm on tracts of land near Wolseley in the Northwest Territories. The government granted the tracts and allowed the immigrants to land and settle in Canada, despite standing restrictions on deaf immigration..$^{35}$ The first and second expeditions spent most of their time in Winnipeg or near Brandon, undergoing agricultural training at the farms of a Major Bell and deaf teamster John Parker. Parker gave the settlers lectures about agricultural practices and employed several of the first group on his farm as labourers, allowing them to earn capital to take up homesteads, in Groom's vision. Despite Groom's reporting of Parker's optimistic message about farming prospects to the settlers, most moved to Brandon or Winnipeg and took up the artisanal trades that they had been unable to practice and left behind in Britain. H.H. reports several deaf immigrants working as printers, cobblers, and blacksmiths by the end of 1884 .

The example of John Parker shows that the Groom settlers were not the first deaf immigrants to settle in the West. Parker, whose 320 acre farm was in the Souris Valley near Brandon, had moved to Manitoba from Ontario in about 1881, having emigrated from Scotland years earlier. Parker was a fascinating figure for Brandonites, as he was mentioned several times before and after 1884 in local papers. He was a member of a local rifle club, a farmer, and a teamster whose reports on his travels around the

\footnotetext{
${ }^{35}$ As Valentina Capurri argues, before 1902 the Canadian government left immigration cases for disabled people to a situational, case study analysis, and gave power to immigration agents to decide themselves. Though a law barring disabled people and "paupers" had been passed in 1869, the government did not perform medical inspections until 1902. The primary question asked of potential disabled immigrants before 1902 was one of self-sufficiency or being able to directly rely on others. Continued British control over Canadian immigration policy also complicated matters. Valentina Capurri, Not Good Enough For Canada: Canadian Public Discourse Around Issues of Inadmissibility for Potential Immigrants with Diseases and/or Disabilities (Toronto: University of Toronto Press, 2019), 14-15.
} 
Northwest drew crowds and newspaper recognition, especially after the 1885

Resistance. ${ }^{36}$ Parker was used by H.H. as an example of what deaf settlers could accomplish in Western Canada, as well as a counterpoint in Conservative papers against the anti-scheme arguments offered by Liberal papers that criticized the Conservative government in Ottawa for allowing the deaf immigration. As we will see in Chapter Five, Parker was also a model settler-Canadian figure with a military past, and celebrated as a deaf man who possessed a story that blended liberal citizenship and a British martial settler persona.

The Winnipeg Daily Times and The Manitoba Free Press argued for weeks in July of 1884 about the Groom scheme. The Free Press, a Liberal organ, argued that the purpose of the scheme was nothing more than to allow "Her Majesty's Government" to send the settlers "to be a burden to the community there." ${ }^{.37}$ The Free Press also argued that "the government should prevent the immigration of people of this kind, poor helpless creatures who would find themselves dependent on the charity of the country the moment they were left to their own resources." ${ }^{38}$ The Free Press, here, was evoking the flexible language of contemporary Canadian immigration policy - deaf immigrants were normatively banned, but a ban based on the local burden they represented was more desirable than a blanket ban. The Daily Time's rebuttal called the prospective deaf settlement "a colony of John Parkers," in a positive allusion to a deaf man who had gone "through the same experiences of other settlers...with such intelligence, honesty, and capacity as to secure for him the largest individual patronage enjoyed in the city (as a

\footnotetext{
${ }^{36}$ See, for example, the Brandon Mail, May 27, 1886, 5.

${ }^{37}$ Manitoba Free Press, undated 1884, quoted in H.H., "A Future," 17.

${ }^{38}$ Ibid.
} 
Brandon teamster). ${ }^{\prime 39}$ Parker, the Daily Times showed, was not the "deaf-mute" of public imagination and prejudice, he was a responsible, intelligent, and prosperous British subject above all. A few papers across the country also weighed in, with the Quebec Chronicle accusing the Free Press of issuing "an incorrect statement" about deaf immigration, while attempting to out-flank the Times in its anti-deaf rhetoric. The Chronicle argued that deaf immigrants could not have been, as the Free Press stated, "dumped into the immigration sheds" because deaf immigration was such a terrible thought that no government would allow it. "Canada wants all the able-bodied she can get - men and women willing to work and make the country of their adoption prosperous and strong, but she does not want paupers and mutes. ${ }^{40}$ The Free Press responded that the Chronicle was correct that their statement wasn't wholly true - because the deaf immigrants "were not dumped into the Immigrant Shed; they got off the train without assistance and walked to it." Elevating their anti-deaf and anti-Groom rhetoric, the Free Press predicted that Groom would be driven "out of the country in disgust at the coarse and brutal abuse heaped upon her while here," but that deaf immigrants would keep coming, and that Groom was to be commended on her "Christian resolve." "The story is true to the extent that they are here," the Free Press wrote, "that more are likely to come and that they are unfortunate. ${ }^{, 41}$ In its attempt to reconcile their resistance to deaf immigration and liberal principles of individuality, opportunity, and obligation to the community of British subjects, the Free Press fell back on the rhetoric of pity and charity: helping deaf people was right, but bringing them to Canada helped neither them nor the country. It was a thin tightrope to walk between the contradictions in liberalism.

\footnotetext{
${ }^{39}$ Winnipeg Daily Times, undated, quoted in H.H., "A Future," 17.

${ }^{40}$ H.H., "A Future," 18.

${ }^{41}$ H.H, "A Future," 19.
} 
The language used by the Free Press, and countered by the Daily Times, was the kind of conflation of disability and poverty that Douglas Baynton finds in his study of American immigration in the late-nineteenth and early-twentieth centuries. ${ }^{42}$ Baynton has argued throughout his career that the language of disability has been used to construct those outside of automatic republican membership - women, Black people, Indigenous people, and others. Canada not wanting "paupers and mutes," in the words of the Free Press, offers an understood connection between the two conditions. The language of disability was often synonymous with the language of poverty in the nineteenth-century British world, an outlook that propped up an overwhelmingly charitable response to disability. This fear, that deaf settlers would become wards of the state, was central in the establishment of the MIDD considered in the next section of this chapter. In the language offered by this study, the Daily Times offered a humanitarian perspective of possible uplift, still relatively rare in 1884, while the Free Press constructed deaf settlers in a purely charitable way - as incapable of self-support and governance.

While Groom did not establish a deaf colony near Wolseley, likely because of disinterest in farming among most of the settlers, most seem to have stayed in Manitoba. Francis George Jefferson, who found work as a printer in Winnipeg, began almost immediately to argue in letters to newspapers that Manitoba should found a deaf school. ${ }^{43}$ He published letters to the editor in both Western Canadian and British newspapers, reflecting on deaf immigration to Canada and the necessity of regional deaf education to those deaf Britons who emigrated to Western Canada. In a letter to the Manchester Courier published in the Free Press in 1886, Jefferson informed potential British deaf

\footnotetext{
${ }^{42}$ Douglas Baynton, Defectives in the Land: Disability and Immigration in the Age of Eugenics (Chicago: University of Chicago Press, 2016).

${ }^{43}$ Carbin, Deaf Heritage, 135.
} 
immigrants of what they would need to expect upon arrival in Western Canada. Wage work was plentiful on farms, but lower paid during the winter months, he wrote. Jefferson also reported that many hearing farmers could "converse well with their fingers. ${ }^{, 44}$ Educational opportunity, though, was scant. "I am sorry to find several of the English mutes (sic) education so imperfect," he wrote, before suggesting that newspaper subscribers in Manchester and Winnipeg put pressure on their governments to improve deaf education in their cities. "I hope the members of Parliament will consider our cause in in a generous way," Jefferson wrote. Manitoba, however, would not have a school for the deaf for another two and a half years.

\subsection{The Founding of the MIDD, 1888-1889}

The Manitoba Institute for the Deaf and Dumb, which would be renamed the Manitoba School for the Deaf in 1914, began as a small private school in the fall of 1888 with James Watson as its sole teacher and Principal. Watson, a Canadian living in Washington State in the late 1880s, was working at the Washington School for Defective Youth, where his father was Superintendent, as a teacher of deaf children. Catching wind of a growing print controversy over Manitoba's need for a deaf school during a visit to Victoria, Watson wrote Manitoba Premier Thomas Greenway to inquire about the province's existing plans for a school and to offer to serve as its principal. "When the initial steps have been taken toward the establishment of such a school," Watson wrote, "what encouragement may I expect from the government?"45 The impetus for a school predated Watson's interest, and a coalition of provincial and municipal politicians, concerned parents, and religious leaders had raised the issue with Greenway over the past

\footnotetext{
${ }^{44}$ Manitoba Free Press, February 11, 1886, 4.

${ }^{45}$ Watson to Greenway, August 9, 1888. PAM, Premier's Correspondence, EC 0016 GR 1662.
} 
year. Thomas Mayne Daly, the mayor of Brandon, wrote a letter to Greenway on behalf of Sarah McPhee, a parent who resented having to send her daughter to the Ontario Institute for the Deaf in Belleville at her family's expense. Daly also reached out to Watson, who reported the details of a survey conducted by Liberal MPPs Gelley and Francis aimed at counting the number of deaf children of school age in the province. "Having heard through the mayor of Brandon that there are about seventy-five (75) or eighty (80) uneducated deaf mutes in the province," Watson wrote to Greenway, "I have decided to open a school for the education and training of that class in Winnipeg in the near future. ${ }^{46}$

Several Liberal MLAs were behind the effort to establish a provincial deaf school, yet their initial efforts failed to convince the Greenway government to support the school financially. Greenway's papers include an undated memo that estimated the potential costs of a school to the province - a cost that seemed so prohibitive to Greenway that he wrote "what part of this will be paid by parents?" at the bottom of the calculations. ${ }^{47}$ In late 1888, the school opened on Portage Avenue with one hundred dollars of funding from the Winnipeg Ministerial Association, who had been convinced to offer funds by Congregationalist Minister Hugh Pedley. ${ }^{48}$ By February 1889, it seemed clear to the government that Watson's private school was struggling financially, so the government passed a bill to make the MIDD a provincial school that offered free tuition, if not boarding, to prospective Manitoba students. It is not clear why the Liberal government changed its mind so quickly in 1889 , though unpublished sessional papers show that there

\footnotetext{
${ }^{46}$ Watson to Greenway, Aug 9, 1888. PAM, Premier;s Correspondence. EC 0016 GR 1662.

${ }^{47}$ Undated memo, office of Premier Greenway. PAM, Premier's Correspondence. EC 0016 GR 1662.

${ }^{48}$ Carbin, Deaf Heritage, 135.
} 
was very little revision in the original draft of the Bill, ${ }^{49}$ so it seems likely that a series of articles in the Manitoba Free Press about Watson's small private school had stirred up public interest and pressure on the government. Greenway commissioned a building design from leading architects, and the school building that served from 1891 to 1918 was built near the corner of Sherbrook and Portage throughout 1890.

The population of the MIDD was initially made up of students in the Winnipeg and Brandon areas. Both Watson and Duncan McDermid, the second principal of the school, pressured the province to enact and enforce compulsory education legislation for deaf children. "I have the addresses," wrote Watson to Public Works Minister James Smart in November of 1889 ,

of about forty mutes of school age living throughout the Province and notwithstanding the fact that I have written to parents of the majority informing them of the privileges the Institution can confer on their afflicted children, they evidently do not deem the matter sufficiently important to favor me with a reply...If a compulsory law is necessary to the well being, educationally, of the child in possession of all his faculties, how much more, not only necessary but humane, is it that such similar law guard the interests and welfare of the deaf mute who has by reason of the absence of such important senses as hearing and the power of speech, is so handicapped. ${ }^{50}$

Watson and McDermid's concerns about the fate of uneducated rural deaf children are rooted in the lack of language acquisition for unschooled deaf children in hearing families. Hearing children who do not learn to read could still converse with those around them and acquire English. Deaf children who were not exposed to sign language could be denied language in a total sense, which is and was very detrimental to childhood development and socialization. Fears of unschooled, and therefore "dependent" deaf

\footnotetext{
49 "An Act Respecting an Institution for the Education and Instruction of the Deaf and Dumb." PAM, Unpublished Sessional Papers. G 8152 LA 0009 GR 174.

50 James Watson to James Smart, November 23, 1889. PAM Ministry of Public Works Incoming Correspondence, GS 0123 GR 1607.
} 
adults allowed for calls for increased state support to drown out calls for ending deaf immigration and migration within only four years of the first Groom expedition.

The MIDD's inability to attract many rural parents of deaf children to part with their company and labour for extended periods of the year remained a persistent problem. The elimination of boarding costs to parents and the CPR's extension of special deaf student rail rates alleviated this only slightly. The prospects of future employment for rural deaf children already well versed and practiced in agricultural tasks were see as distinct from the "privileges' of schooling in many rural families. As Susan Houston and Alison Prentice have written, education and schooling were not synonymous concepts, especially in rural nineteenth-century Canada. ${ }^{51}$ It was only in the mid-1890s, when a weak and poorly enforced compulsory law passed in Manitoba in 1890 began to bite, that McDermid began to shift his concern from unschooled deaf children in Manitoba to those in the Northwest Territories. ${ }^{52}$

During the Greenway government's re-election campaign in 1892, campaign materials published in Liberal papers, especially the Brandon Daily Sun and the Manitoba Free Press, celebrated the founding and continued operation of the MIDD as a victory for state formation and provincial control in Manitoba. The Liberals lumped the MIDD in with other "philanthropic" institutions in this messaging, and suggested that these institutions not only provided necessary attention to the emerging social problems of madness, tuberculosis, and deafness, but that they represented a series of "business

\footnotetext{
${ }^{51}$ Susan Houston and Alison Prentice, Schooling and Scholars in Nineteenth-Century Ontario (Toronto: University of Toronto Press, 1988), 6.

${ }^{52}$ This law featured a twenty-five dollar fine for parents who refused to send their deaf children, but was so poorly enforced that the more expansive law of 1914 is considered, in twenty-first century Manitoba Department of Education literature, to be Manitoba's first foray into compulsory deaf education. See American Annals of the Deaf 35, no.2 (April 1890), 165.
} 
transactions" with the federal government that benefitted both the expansion of the provincial government's responsibility to Manitobans and the filling of provincial coffers with federal dollars. On July $14^{\text {th }}, 1892$, the Brandon Daily Sun published a statement from Greenway that laid this vision out clearly. "The government has exceeded its promises," Greenway wrote, "and not only that, but since taking office the Government has built several public institutions, the Deaf and Dumb institute, the Asylum at Brandon, Home for Incurables at the Portage, addition to the Asylum at Selkirk. A bargain has been made with the Dominion Government for the keep of some 50 Northwest insane at the rate of $\$ 365$ a year each; the cost of each to the Government is $\$ 220$ a year, making a profit in five years which will more than pay for the erection of a new building at Brandon. That was a business transaction., ${ }^{53}$

The following week, the government published campaign material that highlighted its achievement in founding 'philanthropic institutions' while saving the province money and tackling the provincial debt left by the preceding Norquay government. "Vote for a government," ads suggested to readers, "that has saved money and has erected and maintains an institution for the deaf and dumb...Vote for a government that has provided us with needed philanthropic institutions. ${ }^{, 54}$ The MIDD, at least in public messaging coming from the government, was presented as a philanthropic institution grouped with insane asylums and tuberculosis homes, rather than an institution that enshrined the right to an education for deaf children in a province where parents of deaf children had recently won the right to pay taxes for the education of their own children - and not only hearing children - in local public schools. Yet the Daily Sun

\footnotetext{
${ }^{53}$ Brandon Daily Sun, July 14, 1892, 4. Manitobia (www.manitobia.ca), accessed August 14, 2015.
}

${ }^{54}$ Brandon Daily Sun, July 21, 1892, 8. Manitobia. 
surrounded these advertisements with an article about the government's efforts to enact railway disallowance against the CPR monopoly that benefitted central Canadian interests and owned wide swaths of land in Western Canada beyond Manitoba's borders. The combination of humanitarian and fiscal rhetoric seems to have suggested the central message of the campaign - an assertion of provincial rights and responsibilities on terms with Ottawa that financially benefitted Manitoba.

In the early 1890s, then, the Greenway government looked inward at Manitoba deaf students as a philanthropic provincial responsibility, while seeming open to the possibility of accepting NWT deaf students for federal dollars to offset the cost of the school to Manitoba taxpayers. Principal Duncan McDermid, who served from 1890 to 1909, would push both messages as he advocated for the educational opportunities of deaf Manitobans to be extended to the rest of Western Canada. He would highlight the injustice of a lack of schooling for deaf children in Canada simply on the basis of their place of birth or residence, while at times making the argument that federal dollars would aid the Greenway government's program of investing in provincial state building. McDermid, then, was employing both the rhetoric of a more individualistic, transactional liberalism featured in Greenway's re-election messaging and a more expansive collective liberalism that highlighted the state's responsibility to its citizens. These correspond, to some extent, with philanthropic and rights-based approaches to deaf education, respectively. The continuing consolidation of access to deaf education in Manitoba throughout the 1890s would lead to a vigorous debate both in public and between the Manitoba, NWT, and federal governments about how to provide access to education for 
deaf NWT children and youth while protecting the interests and financial liabilities of the three principal parties.

\subsection{The 'Further West Deaf' and Intergovernmental Struggle, 1893-1899}

The Northwest Territories, encompassing the areas currently named Saskatchewan, Alberta, the Northwest Territories, Nunavut, and Yukon, moved toward responsible government by $1897 .{ }^{55}$ Between 1881 and 1905 , the territories' external and internal borders underwent several stages of change. Ontario and Quebec moved northward in 1889 and 1898 respectively, then again in 1912 with Manitoba, which reached the $60^{\text {th }}$ Parallel that year. Internally, the North West Territories Act of 1875, with its 1882 revision, established four districts - Athabaska, Alberta, Saskatchewan, and Assiniboia. Ungava, Yukon, MacKenzie, and Franklin were created in 1895. Until 1875, the Territory was governed directly through the Department of the Interior, with appointed governance prevailing until 1897. In 1885, the Territories reported a population of 48,362 , with 20,170 of those being "Status Indians." 56 The NWT operated on appropriations from Ottawa, with which it was expected to finance its governance, build public works, and run an education system. As we will see, the Canadian government refused to allocate further resources to the Territories to pay for deaf student attendance in Winnipeg.

The NWT struggled to rise above an ad hoc response to deaf education. The governing council only began to pay for some children and youth to attend the MIDD in 1897, after years of pressure from Manitoba, parents of deaf children, and deaf people

\footnotetext{
${ }^{55}$ Officially, the NWT also included most of Ontario and Quebec as well, at the time of responsible government.

${ }^{56}$ David Hall, "North-West Territories, 1870-1905," The Canadian Encyclopedia. (https://www.thecanadianencyclopedia.ca/en/article/north-west-territories-1870-1905), accessed June 23, 2020.
} 
within and without the NWT. Territorial confusion also resulted from the shifting external and internal borders of the NWT. With Manitoba's expansion, some former NWT families fell under Winnipeg's jurisdiction, though it took time for Manitoba to catch up to its duties outlined in the 1889 Deaf Education Act. Families corresponding with Winnipeg recorded the nearest post office as their address, which could be, at times, in a neighbouring district a day's ride away. Borders, before 1905, were difficult to establish, maintain, and honour in the areas of deaf education, and education as a whole. Still, increased correspondence between NWT families, Public Works in Winnipeg, and the Territorial Council in Regina show that the ad hoc situation was failing deaf youth, and that geographical-jurisdictional boundaries needed to be firmed up in order to standardize educational practice. This was only possible after the attainment of responsible government in 1897.

Frederick Haultain, a politician from Fort McLeod, Alberta, became the first Premier of the NWT in 1897. Between 1897 and 1899, the government of the NWT worked to establish a deal with Manitoba to pay for their deaf children to go to Winnipeg, similar to the one British Columbia had already negotiated. The NWT agreed to pay $\$ 275$ plus 50 cents per day for each student, beginning in September $1899 .^{57}$ This settlement, which still only resulted in a minority of deaf children from the NWT attending school in Winnipeg, was the culmination of a concerted effort by Duncan McDermid to engage the governments of Manitoba and the NWT through newspaper publicity, messaging through prominent individuals and social reform groups, and direct correspondence with Regina and Winnipeg.

\footnotetext{
${ }^{57}$ Frederick Haultain to Robert Watson, July 10, 1899. Ministry of Public Works Correspondence, GS 0123 GR 1607, PAM.
} 
Born in Martindale, Ontario in 1858, Duncan McDermid had begun working in deaf education at the Ontario Institution for Deaf Mutes in Belleville as a teenaged clerk. Eventually working his way up to teaching positions at Belleville and the Iowa School for the Deaf by the late 1880 s, McDermid began to find his own political voice after his appointment as principal in Winnipeg in 1890. McDermid was involved in charitable endeavours through his Congregationalist Church, the St. Andrew's Society, and as a Freemason. His ascent to the Presidency of the Manitoba Club in the early twentieth century cemented his place in the city's philanthropic and political elite, and he served on boards that oversaw the Provincial Insane Asylum in Ninette and various organizations advocating for city-wide kindergarten in the 1890s. In turn McDermid used his increasing public profiles as an expert in deaf education and a powerful philanthropist to raise the reputation of the MIDD in the public sphere and advocate for wider social reform in the city. ${ }^{58}$ Over the last decade of the nineteenth-century, his ambition extended beyond the borders of Manitoba, to the cause of the education of what he called the "Northwest Deaf."

Principal McDermid's 1893 Annual Report to the Minister of Public Works featured his first sustained effort to pressure the Manitoba government to work toward a financial arrangement that could allow for the education of deaf children in the NWT. "There are about thirty deaf mutes in the Territories," McDermid wrote, "who are not, as yet, provided with means of education. I have been in correspondence with parents and others, who are anxious to have these children admitted to this Institution, but in every case, the same answer comes, that they are unable to pay for the amount charged for

\footnotetext{
${ }^{58}$ Keith Wilson, "McDermid, Duncan Wendell," Dictionary of Canadian Biography. Volume XII, 19011910.
} 
room and board." ${ }^{59}$ He argued that a similar agreement could be reached between the Haultain and Greenway governments as the one that insured NWT patients "treatment" in Manitoba insane asylums. This agreement rested, however, on the willingness of the federal government to pay the costs involved for the NWT. Between 1894 and 1897, the federal Department of the Interior made only ad hoc decisions about individual students and refused to make broad policy statements about funding.

In internal correspondence with Public Works, McDermid's rhetoric about the 'NW Deaf' was more complex than simply demanding access to schooling. In 1893, he wrote new Public Works Minister Robert Watson to argue that the twenty-six deaf children of school age could also help the school's fiscal health. "If the same arrangement that you have already made with the Dom government could be made to apply to the Deaf of the Territories, we might expect quite a large income from this source," he wrote in a letter that did not make his usual public moral argument about deaf education. ${ }^{60}$ The MIDD was experiencing a serious overcrowding issue that year, and McDermid openly declared in a long letter to Watson that year that he feared for his own children's safety if a serious illness broke out in the school's dorms. ${ }^{61}$ McDermid likely linked the two struggles in his mind, and saw the arrival of NWT students as forcing the province's hand in both school expansion and taking responsibility for educating deaf children in the NWT who were ignored by the federal government.

\footnotetext{
${ }^{59}$ Duncan McDermid, “1893 Annual Report of the Manitoba Deaf and Dumb Institution,” (Winnipeg: Manitoba Institution for the Deaf and Dumb, 1894). 15. Deaf Heritage Room, Manitoba School for the Deaf, Winnipeg.

${ }^{60}$ Duncan McDermid to Robert Watson, Minister of Public Works, January 3, 1893. PAM Ministry of Public Works Incoming Correspondence GS 0123 GR 1607.

${ }^{61}$ Duncan McDermid to Robert Watson, Minister of Public Works, December 7, 1893. PAM Ministry of Public Works Incoming Correspondence, GS 0123 GR 1607.
} 
Overcrowding was a problem throughout the 1890s at the MIDD, and was linked to the reticence of the Manitoba government to wholly endorse McDermid's growing demands that NWT students be accepted at the school. McDermid's December 1893 letter was written at about the same time as his Annual Report for 1893. He reported that, due to insufficient rooms dedicated to female students, some were periodically sleeping in the hallways. ${ }^{62}$ Overcrowding had serious implications for student health, McDermid argued in an impassioned section that dealt with his fears for his own children and his need to be less than candid with parents of students about the school's health and safety. "I feel keenly upon this subject," he wrote,

I have two children of my own at tender ages - the time when they are most susceptible to such diseases as Diptheria, scarlet fever etc., and I fully realize the danger there is and has been to them in an outbreak. It will perhaps be some excuse for my speaking so directly upon this subject but I do not in any sense offer it as an argument in favor of something being done but none for the purpose of impressing upon you and other members of the government as parents the feelings which would naturally arise in the breasts of the parents of our pupils if they fully understood how we were situated...there is nothing in connection with all my duties that has caused me so much mental anxiety as this, and it will be a constant source of trouble until something is done. ${ }^{63}$

McDermid's outpouring did result in an addition being planned and constructed within two years, but overcrowding would not cease to be an acute issue at the school even when the MSD was moved to the University of Manitoba grounds in 1914, then to a new large building of its own in 1922. As we will see in chapter seven of this dissertation, overcrowding was still keeping children that Saskatchewan wanted to send to Winnipeg out of the school well into the 1920s.

The issue of the lack of schooling opportunity for deaf children and youth in the NWT continued to be one confronted by the principal. McDermid's concern, and the

\footnotetext{
${ }^{62}$ Duncan McDermid to Robert Watson, December 7, 1893, 2, PAM GS 0123 GR 1607.

${ }^{63}$ Duncan McDermid to Robert Watson, December 7, 1893, 4-5 and 9. PAM GS 0123 GR 1607.
} 
publicity of the issue, intensified after the arrival of deaf woman named Mona Becker from the NWT at the MSD in 1894. The twenty-four year-old Becker was enrolled at the MIDD that year, after McDermid sent inquiries to her family and community. ${ }^{64}$ The editorial section of the February 1, 1894 issue of Silent Echo featured a reprint of a Manitoba Free Press piece about her. The Free Press related that a woman of about twenty-five had gotten off at the CPR station and was disoriented and distressed. In a summary of an interview with the Free Press, McDermid said that "he never met with another case of a person so absolutely helpless and pitable as one of a young woman, who was brought to his attention on Thursday last." ${ }^{" 65} \mathrm{He}$ further reported that she "could not understand the sign language or alphabet" after an interpreter was sent from the school to the CPR station. McDermid was able to ascertain, at the school, that she had a father further West, and that a note she carried - signed by a man in Brandon, but who left his return address as Wolseley, N.W.T. - explained that "if you want a girl just make signs to her what kind of work and how much per month." ${ }^{, 66}$ The Free Press and Silent Echo were both scandalized by this story, both because of the highly gendered perception of danger in a young woman travelling alone on a train to a (possibly) strange city, and what it showed about the state of deaf education in the NWT. The Free Press, in the story's conclusion, made a plea that seems to come directly from McDermid's mouth:

As the girl appears to have come from the Northwest Territories, her cause brings up the case of her unfortunate class in the Territories for whose education nothing has so far been done. Principal McDermid has information of about thirty deafmutes in the Territories, and of these probably twenty could be admitted to the

\footnotetext{
64 “Mona Becker,” Student Files - Admission Applications (Ab-Zm) 1890-1939. PAM E 0197A Box 1 GR 4531. This student's name, and all students whose information I have accessed through application files and attendance books, is a pseudonym.

${ }^{65}$ Silent Echo (SE) 2, no. 11 (February 1, 1894), 4. Deaf Heritage Room, Manitoba School for the Deaf, Winnipeg.

${ }^{66} S E$ 2, no. 11 (February 1, 1894), 5.
} 
institution if provision were made for them. This would involve an enlargement of the present building and sufficient financial assistance from the Dominion government. Ten or fifteen years hence the little children of the present will be in the sad position of the girl whose case has been described, unless action be taken in time to provide for their instruction, and the success which can be attained in instructing them some years hence will be of a limited kind; the work should be undertaken while they are of tender years. In the meantime the girl in question remains at the Manitoba Institution, though the province has not made provision for such cases and cannot do so unless the Dominion Government also does its share. ${ }^{67}$

The target of the story's arguments was, above all, the Canadian government, which was responsible for the Territory's educational systems until the NWT achieved responsible government in 1897. The Free Press, as a Liberal organ, absolved the Greenway government of blame and placed it squarely on the Tories in Ottawa.

The story continued to gather publicity after McDermid inquired to a Wolseley minister about the woman. Mona's application, generated and filled out by McDermid as details came in, shows that a local religious leader reported that the man who had provided her with the note in Brandon was her brother-in-law, and that she had moved around the West working in various short-term jobs. Her father was on the verge of bankruptcy, as his farm was heavily mortgaged to the Massey Harris Company. "He would like the help of the girl, but I am afraid you need not depend on him," Reverend Campbell wrote. "Her father did not want her to leave home but she preferred to go out towns," McDermid explained in the notes section of the application he was filling out for Mona. ${ }^{68}$ The publicity had an impact, and the federal government made Mona the first student from the NWT to be educated at the MSD, as she attended until 1897. The impact, however, was slight, as an exception was made only for her on an ad hoc basis. One of the only other two students from outside of Manitoba to attend the MSD before 1899,

${ }^{67} S E$ 2, no.11 (February 1, 1894), 5.

68 "Mona Becker," Admission Applications. 
Robert Fischer, was referred to McDermid from the Immigration Sheds in the city and joined the school for the spring of 1894 in a similar ad hoc arrangement. ${ }^{69}$ The Moose Jaw Herald Times, reporting on an impending agreement between the federal and provincial governments, saw a speedy solution over the horizon. "Negotiations are now proceeding between the Department of the Interior and the Manitoba Government for the care, on certain conditions, of at least twelve of these unfortunates, ${ }^{, 70}$ the Herald Times reported, mistaking, in hindsight, the beginning of a protracted inter-governmental struggle for its resolution.

McDermid and Robert Watson received increasing amounts of mail from the families or religious leaders of deaf children in the NWT between 1894 and 1899. The Gainer family from Edmonton was the most persistent, writing repeatedly to the Haultain, Greenway, and Laurier governments in Regina, Winnipeg, and Ottawa respectively. Percy Gainer's parents wrote the federal and Manitoba Ministers of Public Works beginning in July of 1897, reporting that Percy's mother had met with McDermid and J.W. Sifton in Winnipeg and that Sifton had "sed thy were willing to make an exception of the child if the Dominion Government was willing to support him." ${ }^{, 71}$ Correspondence between the Manitoba, NWT, and federal governments continued into the autumn of 1897. Percy's case seemed doomed when James Smart, the Deputy Minister of Public Works in Ottawa, as well as a former Public Works Minister in Winnipeg, wrote a letter to Winnipeg that coldly stated, "I consider that the Government of the Territories should

\footnotetext{
69 "Robert Fischer," Admission Applications.

${ }^{70}$ Moose Jaw Herald Times, August 3, 1894, 1.

${ }^{71}$ J. Gainer to Robert Watson, Minister of Public Works, Winnipeg, July 29, 1897, 2. PAM GS 0123 GR 1607. J.W. Sifton was Inspector of Provincial Institutions in Winnipeg, as well as Clifford Sifton's father.
} 
assume this responsibility."72 The NWT's achievement of responsible government had not improved the Territorial financial position, though it seems to have empowered Ottawa to take a more direct, miserly stand against federal dollars going toward newlywon territorial responsibilities. J. Gainer seemed to have given up by October, as he asked Watson whether "the matter is dropped or if there is any prospect of getting him admitted this fall." ${ }^{, 73}$ Clifford Sifton, however, soon weighed in directly, likely at Watson and J.W. Sifton's personal request, declaring that "I should be glad if you could arrange for the boy's admission, and will be thankful if you will let Mr. Gainer know that I have mentioned the matter to you." 74 Sifton's intervention secured admission for Percy in April of 1898. As he did not go through the official application process, he does not appear in the Admission Application files, but he was still attending in early 1907, as he appears in that year's Annual Report to Alberta. ${ }^{75}$

In his Annual Report for 1897, Duncan McDermid seemed exasperated at the continuing infighting over the issue between the three governments. "It is said that large bodies move slowly," he wrote. "I quite agree with the statement in so far as it refers to the deaf of the Northwest Territories. For the past seven years I have made mention of the [un?]educated of our adjoining Territory and strongly urged upon the authorities the responsibility resting upon them to provide for their education." ${ }^{76}$ McDermid acknowledged the publicity that the issue had drummed up in the previous three years,

\footnotetext{
72 James Smart to Robert Watson, Minister of Public Works, Winnipeg, September 14, 1894, 1. PAM GS 0123 GR 1607.

73 J. Gainer to Robert Watson, October 7, 1897. PAM GS 0123 GR 1607.

${ }^{74}$ Clifford Sifton to Robert Watson, December 17, 1897. PAM GS 0123 GR 1607. J.W. was Clifford's father, and a Greenway patronage hire as Inspector of Provincial Institutions.

${ }^{75}$ Duncan McDermid, "Report form Institution for Deaf, Dumb, and Blind." Department of Education Annual Reports, Edmonton, AB, 1907, 59.

${ }^{76}$ Duncan McDermid, “Annual Report of the Manitoba Institute for the Deaf and Dumb for 1897." PAM GS 0123 GR 1607.
} 
and that Clifford Sifton had finally admitted "that the responsibility rests with the Dominion Government to provide for these children," a likely allusion to Sifton's December 1897 letter to Robert Watson. Still, he seemed unwilling to celebrate this fact, and wrote obliquely that "nothing has been done" despite the efforts of "distinguished gentleman" and the "sympathy and interest" of the public. ${ }^{77}$ To McDermid's frustration, between Percy Gainer in 1897 and a few students in 1899, no formal agreement was forged between the NWT and Manitoba. Even after Haultain's 1899 agreement, access to education at the MIDD remained stuck in a liminal place between state support and charity, an individualized humanitarian response to letters from families and community leaders.

Given the paucity of archival sources in Regina and Edmonton that cover the territorial period's deaf education struggles, it is necessary to rely heavily on correspondence that passed through Winnipeg to form a reconstruction of these debates. Territorial newspapers remarked on the problem, as we have seen, but we have little in the way of internal correspondence from Haultain's government, except that which passed into the hands of Watson's Ministry. From a political point of view, both Winnipeg and Regina blamed Ottawa for not taking its responsibility seriously and issuing vacuous statements of the NWT's responsibility, like Smart's in 1897, but the 1896 Federal Election shifted the political alliances to Liberal federal and Manitoba governments and a Conservative (not in name, but in practice) Territorial Government. It seems that when Haultain accepted the 1899 scheme after nearly two years of trying to extract better terms from the federal government on all Territorial funding, he did so in the context of accumulating letters from parents of deaf children to resolve the issue, and

\footnotetext{
${ }^{77}$ Ibid.
} 
the beginning of the NWT's attempt to begin to move toward provincial status with a federal partner that directly engaged with Liberal members of Haultain's government, marooning him within his own council. ${ }^{78}$ It would be fascinating to consider this from the standpoint of the NWT Council more thoroughly, but the sources at this time do not allow it. Still, six NWT students enrolled at the MIDD in the fall of 1899, becoming the first of an increasing number of students from Western Canada outside of Manitoba and British Columbia to attend under the agreement. ${ }^{79}$

\subsection{Deaf Indigenous Students and the Manitoba Institute for the Deaf and Dumb/Manitoba School for the Deaf, 1890-1925}

Indigenous children and youth from the territories that would become

Saskatchewan and Alberta rarely attended the MIDD/MSD during the time under study. Between 1905 and 1925, only five readily identifiable First Nations or Métis students applied and/or attended the school. I have identified only those Indigenous and Métis students and applicants whose parents or guardians cite them as such in responses to the “ethnicity" question in application forms or in stated ethnicity in Attendance Logbooks, so this number may not be exhaustive. Still, it is clear that Indigenous attendance was a rare and remarkable occurrence before the 1930s, and that those who were accepted had been adopted by white settler families. Métis attendance was also rare but less contingent upon adoption by settler families and is likely underreported here.

The issue of Indigenous attendance arose in 1890 within inter-governmental correspondence. Indigenous children were, as wards of the federal state, subject to

\footnotetext{
${ }^{78}$ Bradford J. Rennie, "Introduction," in Alberta Premiers of the Twentieth Century, edited by Bradford J. Rennie, (Regina: University of Regina Press, 2004), viii.

${ }^{79}$ British Columbia was able to come to an earlier agreement with Manitoba. BC students began attending the MIDD in 1894 with the BC government covering costs for its students and McDermid reporting directly to the BC Minister of Education.
} 
bureaucratic boundaries against attendance at a provincial school. The case of Nepekwan, the deaf son of Blackfoot Chief Aatsistsa-Mahkan (Running Rabbit), is instructive here. On June 10, 1890, Principal James Watson wrote Manitoba Minister of Public Works James Smart to inquire whether Federal Indian Commissioner Hayter Reed's request to have Running Rabbit's son attend the MIDD could be accommodated. Watson inquired, on behalf of Reed and Superintendent of Indian Affairs for Manitoba and the NWT Ebenezer McColl, "what would be charged per term for tuition, board, etc.?" ${ }^{\prime 0}$ It is not clear whether Manitoba eventually balked at having a non-provincial student attend at the time, or if the price quoted for the Department of Indian Affairs was too high. It is clear that Nepekwan did not attend the school, as a Calgary Herald piece from 1898 highlighting his artistic talent makes clear that he was an "expupil of the Crowfoot day school. ${ }^{\prime 81}$ As the later case of Emma Mattis shows, the federal government would, in at least one case, overcome concerns about this cost by violating treaty and misappropriating band funds under Indian Agent control.

Judy Wilson, who was listed as a "Wood Indian" in attendance records, attended the MIDD from 1904-1907. Her application files, filled out by an Anglican minister in the Yukon Territory, makes clear that she was adopted, or in the process of being adopted, by members of the Anglican congregation in the community of Elk Grove, Yukon. ${ }^{82}$ Judy had been educated at a Church Mission school in Elk Grove after she was apprehended "at an Indian camp as a destitute orphan." From available records, little is knowable about Judy's parents, except that they were deceased. Judy's case, as the first identifiably

\footnotetext{
${ }^{80}$ James Watson to James Smart, June 10, 1890. PAM GS 0123 GR 1607.

${ }^{81}$ Calgary Herald, October 13, 1898, 7. Peel's Prairie Newspapers.

82 "Judy Wilson," Admission Applications. In this particular case, both the student and settlement are pseudonymous.
} 
Indigenous student to attend the MIDD, shows how humanitarian adoption schemes could clarify the jurisdictional issues and colonial attitudes that may have held up other Indigenous students from attending.

The end of Judy's life is more possible to document with certainty. In December of 1906, she was sent to the Winnipeg General Hospital with a typhoid fever infection. She died at the General on February 26, 1907, of complications from tuberculosis. McDermid's 1907 Annual Report emphasizes that Judy's illness and death were unexpected but understandable, as McDermid reflected settler prejudices against Indigenous people and tuberculosis susceptibility. His account also highlights that Judy was accepted at the MIDD despite her Indigeneity, though it is difficult to parse what that might mean from available sources. "There was every reason to believe that she was making a good recovery (from typhoid)," McDermid wrote,

However, in January, she developed tubercular trouble and, owing to her weakened condition from the typhoid, she had very little chance to overcome this dread disease; and then, too, being a full-blooded Indian, and like the majority of her race, seemed pre-disposed to tuberculosis, she did not give any evidence of resistance during the rapid development of the disease. Within two months of the time she was sent to the hospital the poor child was in her grave... This child has been with us for the past two and a half years and was of a bright and happy disposition, a general favorite with everyone connected with our school, and without exception she was made to feel in every possible way that she was loved and appreciated. I do not think that she ever had occasion to feel by any treatment on the part of her playmates or others that she was different in colour from other children. ${ }^{83}$

McDermid's description of Wilson's place at the MIDD/MSD makes it clear that her presence was unique and that her "fitting in" was a potential cause of concern for the Principal. Wilson was one of eleven cases of students who died while enrolled at the MIDD/MSD. I will address these cases in more detail in Chapter Five.

\footnotetext{
${ }^{83}$ Duncan McDermid, "Annual Report of Deaf, Dumb, and Blind School, Alberta Department of Education," Alberta Department of Education (Edmonton: King's Printer, 1907), 60.
} 
Four further First Nations or Métis students enrolled at the MSD between 1913 and 1925. There were two Métis students during this time, one descended from a Cree father and French Canadian mother (Stefan Perrault), and one whose father was Métis and whose mother's background was not described (Jane Duchene). Duchene's application appeared after a family breakdown, as her parents were separated and her mother was supporting fourteen children through "outwashing." 84 There seems to be no issue regarding their Métis status, although the number of identifiable Métis students seems lower than one might expect for Western Canada at the time. First Nations students' stories are provided with more detail in applications than those for Métis students, and are more illustrative of larger structural practices. Also, the fact that Métis students could attend provincial-run schools renders their Métis status invisible in the records at times.

Tina Jeffries, from Battleford, Saskatchewan, was the daughter of an Indigenous domestic servant to the Jeffries family. Her mother had attended the Battleford Industrial School and been trained in domestic service. Tina's adoptive mother states that her mother had "worked as a servant in our home until her marriage." 85 It is unclear whether Tina was adopted by the Jeffries family before her mother's marriage or after, but it is key that she was adopted. Adoption, and therefore being on the path to "enfranchisement" seems to have made Indigenous students suitably prospective students. It is difficult, however, to test this hypothesis, given the lack of correspondence about these specific children, and the slight number of examples. Emma Mattis, the child of an Indigenous

\footnotetext{
84 “Jane Duchene," Admissions Applications; "Stefan Perrault," Admission Applications.

85 "Tina Jeffries," Admissions Applications.
} 
interpreter on the Mistawasis First Nation in Saskatchewan, entered the school in $1922 .{ }^{86}$ Her father's status as an interpreter and employee of Indian Affairs likely made Emma eligible for the MSD, though it is difficult to determine this given the lack of detail in her file. Mattis' case is interesting, however, because of her entanglement in the 1935 Dreaver $v$. the King ruling about federal use of band funds for services and items covered by Treaty agreements.

Mistawasis Chief George Dreaver brought suit against the Canadian government and Indian Affairs for procuring health care supplies with band funds between 1919 and 1935, as well as using band funds to pay for Mattis' tuition and board at the Manitoba School for the Deaf. The Saskatchewan government was not required to pay for Mattis' attendance in the same way it would have for a settler student, due to her "Indian" status as a federal ward. It seems that the DIA used band funds, instead of federal Department of the Interior or Indian Affairs monies, to pay for Mattis attendance. ${ }^{87}$ Dreaver has been analysed as an important ruling against the government that established some semblance of order over DIA misappropriation of band funds with respect to healthcare, especially by Maureen Lux, though this decision was not made public until the $1970 \mathrm{~s} .{ }^{88}$ Mattis' case sheds light on how ad hoc the arrangements for deaf Albertan, Saskatchewanian, and Indigenous children could be, although the Dreaver case represents something more than an ad hoc and confusing jurisdictional situation - as Dreaver $v$ King found in 1935, the DIA intentionally stole from the Mistawasis to provide services covered in the 1876 Treaty Six agreement.

\footnotetext{
86 "Emma Mattis," Admissions Applications.

${ }^{87}$ Crossfield Chronicle, September 20, 1934, 5. Peel's Prairie Newspapers.

${ }^{88}$ Maureen Lux, Separate Beds: A History of Indian Hospitals in Canada, 1920s-1980s. (Toronto: University of Toronto Press, 2016), 163.
} 
Robin Jarvis Brownlee argues that federal Indigenous policy was a "complex amalgam of liberal and Tory precepts," at least in its earliest forms. Notions of enfranchisement that would allow for a flowering of individuality and private property ownership, though thoroughly liberal, were at periodic odds with an older, more Tory sense of humanitarian intervention on the grounds of "colonial paternalism." 89 It is perhaps more productive to describe Wilson, Jeffries, and Mattis' experiences as outliers, made permissible to the shaky jurisdictional relationship between the federal government and Manitoba due to a mixture of factors: adoption, parental employment with DIA, and a product of humanitarian intervention by settler families or religious figures. These factors all pointed toward the path of perceived enfranchisement in the present or future. Given this, it is most prudent to conclude that while some Indigenous students did attend the school during the period of study, they were exceptions to a general policy of excluding Indigenous students, one borne of colonial policy and solidified by jurisdictional difficulties between Ottawa and the Western provinces.

\subsection{The Move Toward Provincehood, 1899-1905}

NWT Premier Haultain had abandoned his non-partisan image in the 1896 federal campaign, as he openly campaigned for Conservatives in the NWT against the victorious Liberal government of Wilfrid Laurier. Laurier resisted provincehood for the NWT for a number of years, but offered provincehood to the territory on the condition that his government be re-elected in the 1904 federal election. Haultain and Conservatives had been successful in drawing out territorial resentment against Laurier after 1902, but Ottawa's dangling of provincehood empowered Liberal members in Regina to begin to

\footnotetext{
${ }^{89}$ Robin Jarvis Brownlee, “A Persistent Antagonism: First Nations and the Liberal Order," in Liberalism and Hegemony: Debating the Canadian Liberal Revolution, eds. Jean-Francois Constant and Michel Ducharme. (Toronto: University of Toronto Press, 2009), 304.
} 
marginalize Haultain within his own government. ${ }^{90}$ Haultain sought three conditions for provincehood - the establishment of a single province called Buffalo, the continuance of territorial control over educational policy that had been in effect since 1897, and the handing over of control of natural resources to Buffalo upon the establishment of provincehood. All three were opposed by the federal government, though the new provinces of Alberta and Saskatchewan would retain control over educational policy in 1905 , to the chagrin of Laurier, who had wanted to ensure some modicum of rights for those wishing to have their children educated in French. ${ }^{91}$

Haultain's achievement in keeping provincial control over educational policy left agreements with Manitoba on largely the same footing they had been on since 1899 Alberta and Saskatchewan would pay an annual tuition rate for each student to be educated in Winnipeg. Arrangements had been formalized between the two new provinces and Manitoba between 1899 and 1905, and provincehood saw Saskatchewan and Alberta sending increasing numbers of students to Winnipeg, while others were denied admission due to overcrowding at the MIDD and, after 1909, a commitment from new Principal Howard McDermid to identify and ban students who he deemed to be "feeble-minded," a process that will be discussed in detail in Chapter Six. It is important to keep in mind, however, that compulsory schooling legislation would not be agreed upon in Alberta until 1907 and Saskatchewan until 1917, and that admission of those

\footnotetext{
${ }^{90}$ J. William Brennan, “The 'Autonomy Question' and Alberta and Saskatchewan," in The Prairie West: Historical Readings, edited by R. Douglas Francis and Howard Palmer, 378-396, (Edmonton: Pica Press, 1992), 384-385.

${ }^{91}$ Gordon L. Barnhart, "Frederick Haultain, 1897-1905," in Saskatchewan Premiers of the Twentieth Century, edited by Gordon L. Barnhart, (Regina: University of Regina Press, 2004), xii-xiii; Rennie, "Introduction," viii.
} 
formerly labelled the "NW Deaf," was still conditional on attendance, cost, and, at times, active advocacy by parents and community leaders in the two new provinces.

\subsection{Conclusion}

The development of deaf education in the former Northwest Territories was clearly a small part of the colonialization of Indigenous space in Western Canada. Indigenous sign languages were targeted for elimination by Canadian authorities in the same manner as Indigenous spoken languages. Most deaf Indigenous children were educated in Indian Residential Schools, though a few on the "path to citizenship" did enter provincial educational systems. Bureaucratic categories and state crystallizations governing who had access to institutional education were incomplete at the time of Alberta and Saskatchewan provincehood in 1905, and would remain so until the 1920s. That decade saw a concerted effort from deaf organizations to push governments to enforce their own compulsory education legislation and ensure that all deaf children had access to education. This movement, however, left the issue of deaf Indigenous children out of their political activism, and remained committed to settler notions of terra nullis, settlement, and displacement of Indigenous peoples on the prairies.

As we will see in Chapter Five, the ideological force of settler colonialism remained strong among deaf settler Canadians. If we look at the 1890-1905 period through Michael Mann's lens, the IEMP model, it is clear that ideological and military power worked against Indigenous rights to deaf education, in concert with economic and political power, and that Indigenous people did not live under/in a liberal state. For deaf settler students, who lived in a forming liberal state, political and economic power was liberated from illiberal ideological and military crystallizations, making the issue of deaf 
education possible in Western politics. Still, the issue was framed through a humanitarian lens in public, and few deaf and sympathetic hearing citizens made explicit claims to a "right to deaf education" before the First World War.

The struggle waged by Duncan McDermid, deaf Western Canadians, parents of deaf children, and the editors of Liberal papers for the educational rights of the "Northwest Deaf" shows a progression of rhetoric from a liberal culture that advocated for provincial state formation through administrative expansion to a more expansive liberal culture that fomented a regional focus on educational development in the service of rights for educational rights of deaf children. ${ }^{92}$ These calls for rights were hedged both by the intergovernmental difficulties that held up an agreement that could encompass deaf NWT children until 1899, and more expansive difficulties experienced by both Manitoba and the NWT to ensure school attendance for all students, especially in rural areas of the Prairies. With the coming of provincehood in Alberta and Saskatchewan a framework existed for sending deaf children to Winnipeg, but the resistance of parents in predominantly rural areas, the lack of compulsory legislation, and the weakness of Educational Departments in Regina and Edmonton to locate and accommodate deaf Albertans and Saskatchewanians continued to depress the numbers of deaf children from the two new provinces for decades after provincehood. Overcrowding in Winnipeg also hampered Regina and Edmonton's efforts to send students to Winnipeg. Yet the very real achievements of Duncan McDermid and public advocates for deaf education by 1905 should not go uncounted.

\footnotetext{
${ }^{92}$ As we have seen, Liberal papers only began to advocate seriously for both the MIDD in 1888 and education for deaf NWT youth after these became established positions in Greenway's cabinet.
} 
In Chapter Four, this study will turn to the home lives of deaf children in hearing Alberta and Saskatchewan families both in and out of the Manitoba School for the Deaf. Chapter Five will consider deaf families in the two provinces, as well as the rise of rural deaf communities in the areas near the towns of Lipton, Dysart, and Cupar, Saskatchewan after 1903. In a purely political sense, deaf Saskatchewanians and Albertans experienced a "diasporic period" of deaf education between 1899 and 1931, and 1899 and 1955, respectively. Yet both deaf and hearing parents continued to advocate for their children to travel the long distances required to attend school in Winnipeg for eight months of the year, mostly in the absence of locally viable alternatives. These chapters will, however, form the basis of my argument that twentieth-century hearing families framed deaf educational issues in humanitarian ways, and deaf families sought education for their deaf children as a right and an important facet of community building. Why did deaf and hearing parents of deaf children continue to give up some legal and parental authority over their children? How did their children communicate with them and keep in touch with their local communities while so far away? And finally, how did hearing and deaf parents understand the causes and meaning of their children's deafness, and how important was professional medical discourse to these understandings? 


\section{Chapter Four: "Mingled Joy and Pain": Deaf Children in Hearing Families, 1894- 1931}

"He seemed unaware of his beautiful, Christ-like characteristics which made men love him. It may be said of him that he responded to the 'Follow Me' of his master not alone but by the 'teaching' but most of all by the 'healing' and caring for those who were needy." 1

Eulogy for Duncan McDermid, Silent Echo, 1909

\subsection{Introduction}

In August and September of 1930, Gertrude Thompson of Zehner, Saskatchewan, wrote R.J.D. Williams of the Western Canadian Association of the Deaf several letters about her daughter Betty. In her first letter, Thompson was struggling with several problems brought on by the impending enrollment of Betty in a deaf school. She was notified that summer, like so many other families in Saskatchewan, that the Winnipeg school was at enrollment capacity and that the Saskatchewan Bureau of Child Protection had decided she would be sent to Montreal. Thompson reflected on the pain and stress of sending her young daughter so far for the 1930-31 school year, the need for a deaf school in Saskatchewan, and her daughter's desire to socialize with other children. Williams had recently become a father, and Thompson wrote that he would soon know the "mingled joy and pain engendered by the presence of children." ${ }^{2}$ While it may seem strange that she referred to the presence of children and not the absence, given her fears, Thompson described friction between the desire to keep Betty close to home and the desire for her to receive an education. "I have been thinking myself reconciled to the inevitable," Gertrude Thompson wrote,

\footnotetext{
${ }^{1} S E$ 18, no.1 (October 1, 1909), 1. LRR.

${ }^{2}$ H. Gertrude Thompson to R.J.D. Williams, September 13, 1930, 2. R.J.D. Williams Fonds, 1989-71 Box 1 Correspondence, University of Alberta Archives (UAA).
} 
especially as her daddy with greater strength of will, has steeled himself to see only the advantages of a year's training (at the McKay Institute in Montreal) in the most receptive period of her life...but as the time draws nearer, my will rebels. Aside from the ordeal of separation, I cannot help wondering if it is wise to thrust a defenceless child at the most plastic stage into an environment that cannot be quite suitable...Is there no alternative?"3

The second letter, sent after Thompson had dropped her daughter off at the Regina train station, also recognized that Betty had social and educational gaps that the McKay Institute could work to close. "Betty has no childhood companion here,", Thompson wrote. Her daughter had a "growing desire for companionship with other children," ${ }^{5}$ though it is unclear from the letter whether Betty's deafness or rural isolation explain her lack of friends. Still, even after sending Betty off, Thompson described her efforts to come to terms with Betty's departure. "Our home is empty and silent without our one child," she wrote, "but friends from near and far have done their upmost to ease the pain, and I have kept myself so busy and have been so tired at night that I couldn't take any thought for grief." ${ }^{\prime 6}$ Thompson had suggested that Myrtle Williams, R.J.D.'s wife, could instruct Betty closer to home, or that a small private school could be put together for the Regina children. Gertrude Thompson's struggle with the separation of residential deaf education was hardly unique and had parallels with the initial efforts of the Cameron and Lonsdale families in Winnipeg during the summer of 1888, who balked at sending their children to the Ontario Institute for the Deaf in Belleville.

This chapter will explore hearing attitudes towards, and responses to, deafness through family histories of the diasporic period of deaf education in Alberta and

\footnotetext{
${ }^{3}$ Thompson to Williams, August 7, 1930, 1-2. R.J.D. Williams Papers, UAA.

${ }^{4}$ Thompson to Williams, September 13, 1930, 3. R.J.D. Williams Papers, UAA.

${ }^{5}$ Thompson to Williams, September 13, 1930, 3. R.J.D. Williams Papers, UAA.

${ }^{6}$ Thompson to Williams, September 13, 1930, 2. R.J.D. Williams Papers, UAA.
} 
Saskatchewan. Application forms, correspondence, and the (Silent) Echo can offer a glimpse into the economic, emotional, and political dimensions of years of separation between deaf children and their deaf or hearing families. The experience of separation from parents, however, offered children opportunities to make deaf friends, encounter deaf adults, and find a place within an emerging deaf community in Western Canada and beyond. It allowed them to learn sign language in addition to written, finger-spelled, or spoken English, and to "learn how to be deaf." As R.A.R. Edwards points out, this phrase can have a double meaning - to learn how to perform as a "disabled" citizen, but also to join the deaf community. As Edwards argues, most deaf students entering residential deaf schools learned sign language from their peers, not teachers, even before oralism's ascendance in the early twentieth-century. ${ }^{8}$

Writing early twentieth-century family histories that include deafness is challenging. Many deaf children felt isolated in their own hearing families, and found new important social networks and friendships at school. Those from deaf homes may have had a no less shocking experience in arriving at school, as the Manitoba School for the Deaf increasingly moved toward privileging "English as the legitimate language for use in education," ${ }^{, 9}$ in spoken, written, and finger-spelled form, even while allowing sign to proliferate in the social spaces of the school. The deaf educational system in Western Canada helped to perpetuate the dual sense of belonging in many deaf graduates, those who had both hearing families and deaf non-kin families. As this chapter will argue in

\footnotetext{
${ }^{7}$ Jane Berger, "Uncommon Schools: Institutionalizing Deafness in Early Nineteenth-Century America," in Foucault and the Government of Disability, ed. Shelley Tremain (Ann Arbor: University of Michigan Press, 2015), 154.

${ }^{8}$ Edwards, Words Made Flesh, 51-60.

${ }^{9}$ Linda Komesaroff, Disabling Pedagogy: Power, Politics, and Deaf Education (Washington, D.C.: Gallaudet University Press, 2008), 2.
} 
part, this dual identity was feared by hearing parents who increasingly demanded that their children learn English in all forms and be made able to enter hearing employment and social networks. This enclosing of a vague borderlands between hearing and deaf worlds has been considered from the perspective of elite intellectual history ${ }^{10}$ and from that of deaf students and organizations, ${ }^{11}$ but rarely from the standpoint of hearing parents and their growing political power in the progressive era, ${ }^{12}$ as this chapter does. This chapter will deal with children who attended school and children who did not, as well as partially and profoundly deaf children in manual and oral streams. In order to do justice to this complexity, it is necessary to begin with children's circumstances in their homes, before school attendance.

\subsection{Bureaus of Child Protection and Compulsory Schooling}

Child protection, including the insurance that work and neglect would not interfere with educational opportunity, spread west with Children's Aid Societies that emerged from a Toronto model established by J.J. Kelso in the 1890s. Within ten years, both Alberta and Saskatchewan ran private and local Children's Aid Societies administered by provincial Bureaus of Child Protection. ${ }^{13}$ These bureaus granted funding and provincial certification to CASs that apprehended neglected and abused children, but they also stepped in to overtake CAS efforts to manage local responses to disabled children, including deaf youth. By the end of the First World War, Saskatchewan and Alberta had constructed a small bureaucracy around locating deaf children and sending them to Winnipeg or Montreal for educations. These bureaucracies, however, remained

\footnotetext{
${ }^{10}$ Baynton, Forbidden Signs.

${ }^{11}$ Burch, Signs of Resistance; Buchanan, Illusions of Equality.

${ }^{12}$ Ellis, A Class by Themselves?, 139.

${ }^{13}$ These BCPs existed in both Alberta and Saskatchewan, but were originally called the "Bureau of Neglected Children" in both provinces.
} 
weak and often ineffective into the Great Depression, and struggled to actually impose the weight of existing compulsory education laws for all children. Gauging the strength and seriousness of these efforts in Alberta and Saskatchewan is difficult, however, as only Annual Reports and limited correspondence remain in those province's archives. Saskatchewan records of the activities undertaken by Bureau of Child Protection home agents, who visited towns and cities looking for cases of neglect and disability, have been lost.

Oversight of deaf education in Alberta and Saskatchewan between 1905 and the early 1930s was similarly structured. Bureaus of Neglected Children dealt directly with children and their parents, while the Departments of Education received reports from the Manitoba School for the Deaf and compiled public statistics on deaf students. This placed deaf children and youth under the jurisdiction of two government bodies - a BCP tasked with dealing with "dependent and delinquent children"14 and a Department of Education tasked with managing Alberta and Saskatchewan's relationship with Manitoba on deaf educational issues. BCP annual reports filed with the Alberta Attorney General from 1909 to the end of the First World War dealt at length with "mentally defective" and homeless children but rarely mentioned deaf children and their educational needs. Successive superintendents in both provinces wrote similar texts in their reports for these ten years, arguing that their respective provinces were failing to address the problem of

\footnotetext{
${ }^{14}$ Dependent children referred to children who were understood to rely on the state for education beyond the needs of "normal" children - including deaf, intellectually disabled, and blind children. Delinquent children were described in the Alberta BNC's first Annual Report as "normal" but the victim of "abnormal circumstances," meaning neglect and abuse. R.B. Chadwick, Annual Report of the Superintendent of Neglected Children of the Province of Alberta (Edmonton, James Richards, Government Printer, 1910), 9. Alberta Legislative Library, Edmonton.
} 
"feeble-mindedness," and that increased immigration was compounding the problem. ${ }^{15}$ Superintendents Chadwick of Alberta or Page, then Reynolds, of Saskatchewan, did not act so urgently when it came to the numerous deaf students who were kept out of school by their parents. ${ }^{16}$

This separation also heightened a disconnect between bureaucratic bodies in both provinces charged with establishing and enforcing compulsory schooling laws. Alberta had established compulsory education by 1909 , and Saskatchewan followed suit in 1917, but neither province enforced the law with a sustained sense of purpose. Rural children worked on their family farms, or on their own for wages, heightening resistance to centralized schooling on the part of their rural parents. As we will see in Chapter Seven, the Saskatchewan Bureau of Child Protection actively ignored the Western Canadian Association of the Deaf's first attempts to learn the number of deaf children of school age in the province in 1927 - and it was the WCAD, with help from the Western Producer, that undertook this work for the Saskatchewan government. As late as 1922, correspondence between Acting MSD Superintendent Gordon Lilley and W.M. Martin, the Saskatchewan Minister of Education, betrays Martin's own confusion about whether the province's law covered deaf children and youth. Martin, in answering Lilley's concern about two students pulled from Winnipeg by their parents, eventually avoided the legal question by arguing that "we have no provisions under which we can compel

\footnotetext{
${ }^{15}$ Superintendent of Neglected Children, 1912 Annual Report, Dependent and Delinquent Children, Alberta. (Edmonton: Government Printer, 1913), 44. Alberta Legislative Library, Edmonton.

${ }^{16}$ Spencer Page died in his office on September 10, 1916, and F.J. Reynolds took over shortly after as Superintendent of Neglected Children in Saskatchewan. He would change the Department's name to the Bureau of Child Protection within a few years.
} 
people who have deaf children to send them to a deaf and blind institution. ${ }^{.17}$ From a governmental perspective, the enforcement of compulsory schooling laws and the provision of educational opportunities for deaf children whose parents wanted to send them to school were confused, ad hoc, and unclear during the period under study. As we will see in Chapter Seven, the WCAD's effort to bring a school to Saskatchewan were rooted in the group's earlier efforts to force provincial accountability for deaf education more widely, even within the system of sending children to Winnipeg or Montreal.

This chaotic system led to a poor communications strategy to inform parents of deaf children in both provinces of the opportunity for free (or in the case of Saskatchewan before the 1920s, subsidized) deaf schooling in both provinces. ${ }^{18}$ Correspondence to R.J.D. Williams of the WCAD between 1927 and the opening of the Saskatchewan School for the Deaf shows parental confusion over provincial funding and access to be a stumbling block in the path of an effective deaf education system in the province. One parent, in response to a circular in the Western Producer calling for the government to deal with an overcrowding crisis in Winnipeg, wrote to Williams that

You mention in your letter that the government bears the expense, I always thought the parents had to pay and we often wondered and worried how we could send our girl away to school as we only have $1 / 4$ section of land and make a fair living off it but with added expense for years we did not know how we would manage. Therefore we were very glad to read your letter in the paper. And hope that it will help us in solving a very perplexing problem. ${ }^{19}$

\footnotetext{
${ }^{17}$ W.M. Martin to Gordon Lilley, February 13, 1922. Department of Education Correspondence, 1922-29, PAS.

${ }^{18}$ It seems that the issue of parental tuition coverage was means-tested, but incompletely regulated. It is not clear when this policy ended, or how many parents actually paid $50 \%$ of tuition. It likely continued for some parents until 1929, when the province dropped the stipulation from the 1928 SSD legislation. ${ }^{19}$ Mrs. Thomas Evans to R.J.D. Williams, November 7, 1927,2. RJD Williams Papers, 89-71 Box 1 Correspondence, UAA.
} 
Parental confusion about government provision, combined with the reticence of some parents to part with their children for months at a time, contributed to the persistence of rural resistance to the residential deaf school model, especially the distance model that prevailed in Saskatchewan before 1931 and Alberta before 1955. Other parents commented on the financial difficulty of even paying subsidized rail fare and buying suitable clothes for their children. Henry Sabat of Main Centre, Saskatchewan wrote to Williams that "we are unable to buy all the necessity of clothes and such for the season. I would like to know if you, or the Sask Committee could help me in any way so we could make it possible to send the boy to the school."20

Hearing parents of deaf children often found themselves in uncharted territory that interrupted received educational expectations. Parents were confronted with the proposition of sending their children hundreds of miles away for months at a time and being deprived of their children's company and labour. While parental responses to the often unexpected challenge of navigating an opaque and confusing system of deaf education ranged from refusal to part with their children to advocacy for their children's educations at any cost, by the late 1920s parents mostly united around the need for a provincial deaf school in Saskatchewan, if not Alberta. Parents called for the economic and legal power of the state to provide educational provision for hearing and deaf children alike. As Axel Sjolin of Kinistino, Saskatchewan argued, "it seem to me that

\footnotetext{
${ }^{20}$ Henry Sabat to R.J.D. Williams, September 5, 1927, 2. RJD Williams Paperss 89-71 Box 1 Correspondence, UAA.
} 
they (the Saskatchewan government) are doing a lot toward looking after the Education of the hearing children why not do a little more for the Deaf?"21

\subsection{Deaf Children in Hearing Families: Labour and Poverty}

The rural nature of much settlement in Saskatchewan and Alberta contributed to these problems as well. As historical sociologist Sandra Rollings-Magnusson makes clear, the homesteading process often required sustained child labour for years after settlers arrived at their sections. This need for child labour was coupled with deep justifications of the practice, as parents and social commentators alike saw farm labour as training for future work in an ideal natural setting. ${ }^{22}$ Contrasting stifling city childhoods with rural upbringing in "Nature's classroom," social commentators often exempted farm labour from the growing movement against child labour in mines and streets nationwide. ${ }^{23}$ Deaf and hearing children alike worked on their family farms, often preparing for futures in agricultural labour on their own land and in their own homes, or for wages. At the same time, application forms and correspondence from Alberta and Saskatchewan to the MSD and WCAD show that many farming parents still saw the attainment of some level of education as important.

Of 398 applications to the MSD between 1890 and 1931 from areas now known as Alberta, Saskatchewan, and Yukon Territory, 190 came from families whose primary

\footnotetext{
${ }^{21}$ Axel Sjolin to R.J.D. Williams, December 30, 1927. RJD Williams Fonds 89-71 Box 1 Correspondence, UAA.

${ }^{22}$ Sandra Rollings-Magnusson, Heavy Burdens on Small Shoulders: The Labour of Pioneer Children on the Canadian Prairies. (Edmonton, University of Alberta Press, 2009), 19-25.

${ }^{23}$ Rollings-Magnusson, Heavy Burdens, 25. The quote is from an 1898 editorial in the American magazine The Judd Farmer.
} 
reported source of income was farming. ${ }^{24}$ This number surely underestimates the number of farming families who filed applications, as it does not include those applications that came from parents or guardians who did not specify an occupation for the father or mother in the family. Recent scholarship has shown that Canada as a whole remained more rural than previously argued, and that the notion that the 1921 Census shows a majority-urban Canadian population were based on uncritical readings of that Census. ${ }^{25}$ The rural populations of Alberta and Saskatchewan also remained disproportionately large in comparison to other Canadian provinces up until the Second World War.

Deaf children's labour on farms was central to the economic and social fabric of their families' lives. Application forms point to the financial precarity of many of these families. 228 of those who specified their financial status chose "indigent" from the available classes of "indigent," "easy," "affluent," and "fair.", Some families may have underreported their economic circumstances, especially in Saskatchewan where "affluent" families were required to pay up to $50 \%$ of the cost of education until the $1920 \mathrm{~s}$. The MSD application forms from 1890 to 1931 respondents to evaluate "what the child can do around the house," and most parents replied that children could work on the farm as well as any child their age. ${ }^{27}$ It is clear from the application documents that many applicants worked directly on their family farms, as many children were documented as being versed in farm work, driving horses, and other household tasks.

\footnotetext{
${ }^{24}$ Student Files- Admission Applications (Ab-Zm) 1890-1939. E 0197A Box 1 GR 4531, PAM.

${ }^{25}$ Ruth Sandwell, Canada's Rural Majority: Households, Environments, and Economies, 1870-1940 (Toronto: University of Toronto Press, 2016), 2-4.

${ }^{26}$ Admission Applications, 1890-1939, PAM. The choices from the NWT, then SK and AB are as follows: indigent -228 , easy- 72, affluent -4 , fair -17 .

${ }^{27}$ Admission Applications, 1890-1939, PAM.
} 
While many rural parents did send their children to Winnipeg, some sent them for only a short time. William Tucker initially applied in 1888 at the age of fourteen while a Manitoba resident, but only attended the MSD for one year before his parents withdrew him because he was "needed at home." ${ }^{, 28}$ The MSD received another application for Tucker, who resided in Alberta in 1903, but McDermid rejected him as "too old," given that he was twenty-nine years old by this time. Rural parents who valued their children's labour tended to apply for their children at late ages and at times not at all. Several applicants were reported as having an older deaf sibling who had never been to school and was now too old to be enrolled.

Application records show that, during the years under study, poverty was endemic on the Prairies and parkland. This poverty was punctuated by larger events, especially the First World War and the 1918-1919 influenza epidemic, and often resulted in a fiscal or familial breakdown that could see parents apply for their children to attend the MSD for the first time. This breakdown could be sudden and shocking - as in the case of a parent's death - or gradual, following a period of unemployment or after a breadwinner's disability.

One observable cause of a gradual breakdown was a father's service in the First World War. These included physical disabilities and amputations that made postwar work difficult, acquired sensory disabilities, and psychological trauma suffered at the front. Saskatchewanian Tom Howard was nine years old when his mother applied for him to attend the MSD in 1920. His father had been killed in the war, and his mother took up work as a seamstress to support her small family. This strategy likely also involved

28 "William Tucker," App \#1 and 144. Admission Applications, 1890-1939, PAM. 
sending Tom to the MSD, where her financial obligations to him would be minimal during the school year. ${ }^{29}$ Other children's fathers returned with disabilities that limited family income. Julie Windsor's father was deafened by shellfire, and reported that the family was indigent upon her 1928 application for that reason. ${ }^{30}$ Likewise, Carla Rolling's father returned from the war, but the family's income was limited because her "father is a returned soldier whose earning capacity is limited due to ill health incurred in active service. ${ }^{\not 1}$ While the war affected the economic prospects of some families with deaf children, the influenza pandemic was seems to have had more effect.

Influenza both killed parents of deaf children and caused children's deafness. The MSD itself avoided serious consequences from the pandemic, with a majority of students becoming ill but none seriously. "When the provincial health officer ordered all public meeting places and theatres closed," The Echo reported, the boys and girls were not allowed to go to the city or to their homes." ${ }^{32}$ The school was closed for three weeks in November 1918 as forty-nine boys and sixty girls came down with "mild" cases of the flu. The Echo projected a sense of humour about the pandemic ravaging Winnipeg, though: "Spain has, through the centuries, secured a considerable amount of free advertising in the form of Spanish Inquisition, Spanish Armada, Spanish Fly, Spanish Onion, Spanish Eggs, and Spanish 'Flu.' ${ }^{, 33}$ Still, the disease's effects were felt for a decade after 1919, as children who lost parents or were deafened in the pandemic continued to apply for admission throughout the 1920 s.

\footnotetext{
29 “Tom Howard," App \#609. Admission Applications, 1890-1939, PAM.

30 "Julie Windsor," App \#690. Admission Applications, 1890-1939, PAM.

31 "Carla Rollings," (no app \#, 1930) Admission Applications, 1890-1939, PAM.

${ }^{32} T E$ 26, no. 2 (November 15, 1918), 4, LLM.

${ }^{33}$ TE 26, no. 2 (November 15, 1918), 5, LLM.
} 
Betty Gamble's mother applied for her to attend the MSD shortly after Betty's father died of influenza in 1919. Beside a question asking for the family's economic condition, her mother wrote "do not know," signifying that the loss of Betty's father uprooted the family's finances in ways that were just beginning to be managed by her mother at the time of application. ${ }^{34}$ Three children who applied to the MSD in the 1920s became deaf after becoming seriously ill during the pandemic, though the number could be higher, given the under-reporting of causes of deafness in applications, as well as the spurious nature of some of the given causes, which we will revisit later in this chapter.

Several applications came from rural families after sudden family breakdowns due to the illness and death of a parent. Brett Malarchuk's father died by suicide on Christmas Day 1928. His mother was left with nine children, and seems to have turned to sex work to try to make ends meet. Brett's application was filed by the Alberta Bureau of Child Protection in 1929, suggesting that he and his siblings were placed under DNC's care shortly after their father's death. ${ }^{35}$ Malarchuk attended the MSD in 1930 and moved to the new Saskatchewan School for the Deaf in 1931. Andrew and Gunter Olsen's father filled out applications for them in 1913 after the death of his wife, though they did not attend that year. Andrew and Gunter had an older brother who was also deaf but seems not to have attended any school, and their father described their financial situation as "affluent" in 1913 and his occupation as a farmer. ${ }^{36}$ A guardian reapplied at the shortlived SSD in Regina for the two boys in 1915, stating that their "father has gone away and guardian does not know where he is, pecuniary condition indigent." The death of a

\footnotetext{
34 "Betty Gamble," App \# 624. Admission Applications, 1890-1939, PAM.

35 "Brett Malarchuk," App \# 729. Admission Applications, 1890-1939, PAM.

36 “Andrew Olsen,” App \# 457; “Gunter Olsen,” App \# 458. Admission Applications, 1890-1939 PAM.
} 
primary breadwinner did not always lead to poverty and an immediate application, however. John Inglewood's mother, after her husband's death from influenza in 1919, took a job as a stenographer. She reported in John's application that "I support myself and (the) boy. ${ }^{37}$ Since MSD application forms after 1911 asked for both a father and mother's occupation, the records show a small number of single mothers supporting their families through manual labour, seamstress work, stenography, and administrative assistance jobs. It was the death of a mother that seems more likely to immediately lead to an application for students above school age, as in the case of the Olsens.

Deaf children in Alberta and Saskatchewan during the time under study, then, seem to have been sent to school later than many of their hearing counterparts, though the lack of detailed information about both deaf and hearing children outside of public schooling make this assertion somewhat problematic. Rural children in general were more likely to be held out of school or withdrawn early, and the distances travelled by deaf students to Winnipeg or Montreal likely made parents more reticent to lose their valuable labour. Parents also felt the emotional burden of seeing their children travel long distances to attend school for much of the year, as we have seen in Gertrude Thompson's 1930 letters to R.J.D. Williams. Poverty could push families to send children to the MSD offset some of the cost of child-rearing, but holding children back for their labour seems to have been more common.

\subsection{Hearing Parents, Deaf Education, and Liberal Futurity}

Many hearing parents sent their deaf children to the MSD out of their fear that their child had suffered a life-altering tragedy. For these parents, education held allure as

\footnotetext{
37 “John Inglewood,” App \# 655. Admission Applications, 1890-1939, PAM.
} 
a way for their children to build productive futures. Most hearing parents did not know deaf people, or at least signing deaf, and held unscientific attitudes about deafness and its causes. As we will see in Chapter Five, deaf parents did not share these experiences, and increasingly saw futures for their children that involved living in both hearing and deaf communities in a state of empowered fluidity or "co-equality." ${ }^{38}$ For hearing parents, the future seemed bleak for their deaf children, and many accepted residential education as a necessary cost to ensure productive futures for their children. Many did not have strong opinions on the manual/oral methods debate, though, as we will see, the MSD avoided depictions of signing in Silent Echo and The Echo, a key conduit for keeping parents and children connected over provincial lines.

Most hearing parents saw their children's deafness, whether congenital or acquired, as a tragedy. Disability Studies scholars and historians of disability have recently turned toward an emphasis on differentiated futurities between disabled and nondisabled individuals. Alison Kafer argues that limiting futurities are imposed on those who are seen as being outside of teleological conceptions of individual futures, including queer and disabled individuals. ${ }^{39}$ Theorizing about disabled lives in a way that honours the possibility and lived experience of those lives in the past and present requires a view of diversity on experience, rather than a focus on a single possible life cycle. The term "disabled," however, encompasses a myriad of different impairments or bodily differences, so it is important to not simply argue, through the backdoor, that Disability Studies should simply reconfigure existing disabled futurities in order to reify what Kafer

\footnotetext{
${ }^{38}$ Murray, "One Touch of Nature."

${ }^{39}$ Kafer, Feminist, Queer, Crip.
} 
calls a site of "no future." ${ }^{40}$ Stacy Clifford Simplican argues that disability studies relies too heavily on the emotional push of proximity to disability within families, and not enough to the pull of a rights paradigm. Attributing politics around disability only to parents motivated by emotional connection to their children risks "depoliticizing disability by continually cloaking it in within a familial framework." ${ }^{41}$ Though there was a divide between hearing and deaf parents on the issues of why deaf education should be supported by government, hearing parents nevertheless saw education as a levelling mechanism for their deaf children that should be afforded as government policy. Similarly, Stephanie Bangarth and Jennifer Tunnicliffe argue that this rights paradigm should be taken seriously by scholars of all subaltern political movements, regardless of when the notion of "rights" can be exactly historicized. ${ }^{42}$ These points will be central to this chapter and the next, as the horizons of possibility for deaf children were largely either tragically emplotted or not, depending on if they grew up in hearing or deaf families.

Late Victorian and Edwardian thinkers often contrasted normative futurities with hearing parent's visions of possible futures for their deaf children, in which the former was "independent" and the latter was "dependent." Many hearing parents created a bridge to an imagined liberal futurity through deaf education, which afforded their children "a fair shake." Hearing parents in this study, when held up to dominant theorizing in the Disability Studies field, are more complex than able-bodied subjects described by Rice, Chandler, and Rinaldi - who see the future in terms of a forced choice between "future

\footnotetext{
${ }^{40}$ Kafer, Feminist, Queer, Crip, 10.

${ }^{41}$ Simplican, The Capacity Contract, 15.

${ }^{42}$ Bangarth and Tunnicliffe, "Writing Rights," 642.
} 
perfect" and "no future.". ${ }^{43}$ Here, it is important to draw distinctions that theorists do not - that deaf children had recourse to imagined futures beyond "future/no future," especially when compared to intellectually disabled or Mad people in history, and when race and class are also seen as factors. Amid the rise of scientific and popular commentary on the influence of negative heredity on descendants, through the prism of eugenics, hearing parents seem to have protected themselves and their children from what they saw as a destiny of dependence, and to give themselves control over their children's futures. As we will see, parents often distanced themselves from the idea of heredity in applications, deciding instead to assign blame for the "tragedy" to their own choices, to God, or to inexplicable randomness.

Hearing parents often described their children's deafness in tragic terms. When identifying the cause of the child's deafness in application forms, parents often gave different reasons than the doctors they had consulted or with whom they were filling out the application. Most parents reported that the child was either born deaf or became deaf by childhood illness. Even within these two categories, they often imposed tragic narratives or Providential interference. Karl Covey, who applied from Saskatchewan in 1914, had arrived on the family plot with his Ukrainian parents as a baby in 1899 . According to his mother, he was "born in a dugout in the early spring with no mode of heating," and was "black and blue from cold." ${ }^{, 44}$ His mother attributed his deafness to an illness brought on by this situation, though she also considered him to be deaf from birth. Karl had, at the time of application, never been examined by a doctor.

\footnotetext{
${ }^{43}$ Carla Rice, Eliza Chandler, Jen Rinaldi, Nadine Changfoot, Kirsty Liddiard, Roxanne Mykituk, Ingrid Mundell, "Imagining Disability Futurities," Hypatia 32, no. 2(Spring 2017): 213-229.

44 "Karl Covey," App \# 373. Admission Applications, 1890-1939, PAM.
} 
Parents also appealed to Providence, whether spiritual or naturalistic, to tragically frame their children's deafness. Five parents reported "God's wisdom" or "God's will" as the cause, even if doctors disagreed on the same document. Another parent reported that her daughter's deafness was caused by "a freak of nature" in an application filled out in 1908. ${ }^{45}$ Application forms also imposed some stigma on those whose children may be perceived as having acquired deafness hereditarily, as forms explicitly asked if "does the child have any deaf and dumb, blind, or idiotic relations? Any relations who have spent time in an insane asylum?" ${ }^{, 46}$ Hearing parents rarely gave responses that evoked hereditary reasons for deafness, offering individual tragedy and Providential agency instead. One father, next to the hereditary question, wrote simply "NO!" in response. ${ }^{47}$

One exception to the above statement relates to consanguity. Several parents were first cousins, and reported this as a cause of deafness even if doctors disagreed. The Weigel family of Pelly, Saskatchewan were an interesting case of this phenomenon. The family, which included eight children, sent six to the MSD between 1912 and 1924. The family applied for two children three different times - in 1912 for Eliza and Don, in 1915 for Casey and George, and in 1917 for Melanie and Trudy. In 1912, the children's father wrote in his application that the cause of deafness was that he and his wife were first cousins, a reason that he gave on all six applications. A doctor's comment and signature was only obtained for the 1915 application, where a doctor reported the cause as "hereditary." Under this, the father wrote "do not agree it is the relationship." ${ }^{, 48}$ Likewise,

\footnotetext{
${ }^{45}$ App \# 215. Admission Applications, 1890-1939, PAM.

${ }^{46}$ MSD Application form, blank, c.1915. Admission Applications, 1890-1939, PAM.

${ }^{47}$ Application \# 642. Admission Applications, 1890-1939, PAM.

48 "George Weigel," App \# 454. The other children's app \#s are: Eliza (297), Don (296), Casey (452), Melanie (514), and Trudy (515). Admission Applications, 1890-1939, PAM.
} 
Martha Smith's mother wrote that her cause of deafness was "parents being related (first cousins)," while she reported that the doctor thought her "ears were not fully developed, hereditary." ${ }^{, 49}$

The distinction between "hereditary" and "consanguity" seems arbitrary but actually stakes out key ground in notions of disability at the beginning of the eugenic age. As Madeline Burghardt argues, families faced stigma, both socially and self-imposed, for having a child with a disability perceived as hereditary. ${ }^{50}$ Stacey Burke argues that in the early twentieth-century, Victorian ideas of the importance of biography and hereditary tracking remained essential to imposing professional narrativity on what could be acts of contingency rather than destiny. ${ }^{51}$ Attributing what hearing parents often saw as a familial disaster to contingency - even a stigmatizing choice - was preferential to admitting that deafness may "run in the family," a condition that the MSD's application forms linked with blindness, "idiocy," and insanity. A number of parents seem to have hidden their own deafness or histories of mental illness when applying for their eldest child to go to the MSD, only to disclose these in later applications. Parents also became more likely to identify deaf or disabled family members in the twentieth century than they seemed to be in the nineteenth-century, though this could be explained by the rise in numbers of applications over time..$^{52}$

\footnotetext{
49 "Martha Smith," App \# 333. Admission Applications, 1890-1939, PAM.

${ }^{50}$ Madeline Burghardt, Broken: Institutions, Families, and the Construction of Intellectual Disability (Montreal and Kingston: McGill-Queen's University Press, 2018.

${ }^{51}$ Stacey Burke, Building Resistance: Children, Tuberculosis, and the Toronto Sanitarium (Montreal and Kingston: McGill-Queen's University Press, 2018), 11.

${ }^{52}$ Admission Applications, 1890-1939, PAM. In the nineteenth century, only one application named deaf relatives. Between 1906 and 1914, 15/92 did so. Other numbers are: 1915-1920: 21/117, 1921-1925: 20/104, 1925-1930: 11/48.
} 
Hearing parents also could place the cause of deafness in rather fantastical situations, belying their unfamiliarity with any medical expertise on what can cause deafness at birth. Charles Howe, in his 1888 publication The Deaf Mutes of Canada, reported parents who blamed visual or physical encounters with signing deaf people during pregnancy as the cause of the birth of a deaf child. ${ }^{53}$ These "maternal impressions" were a commonly seen as cause for congenital disabilities before the advent of eugenics. ${ }^{54}$ Several parents reported unscientific or unverified causes of deafness for their children well into the 1920s, showing that the passage of decades did little to dispel the notion that deafness could be caused by non-medical and traumatic experiences. These explanations were usually offered by parents in opposition to the diagnoses of doctors, and could perhaps have worked to shield hearing parents from the stigma of possible hereditary causes that blamed family and ancestors, rather than chance and contingency.

Millie Fulton's parents reported that although she was born deaf, a trauma suffered by her mother caused her deafness. Her parents were reportedly at a theater before her birth when a gunshot rang out during a performance. Millie's father reported, in her 1913 application, that the cause of her deafness was the "discharge of a revolver in a theatre." ${ }^{55}$ Fulton's doctor, however, reported "no cause," suggesting, but not specifying, hereditary causes. Gertrude Sutcliffe, born in 1899 and admitted to the MSD in 1906, was one of five applicants whose parents suggested that a mother's physical or emotional connection with a deaf person was the cause of her child's deafness.

\footnotetext{
${ }^{53}$ Charles J. Howe, The Deaf Mutes of Canada: An Account of Their Education, With an Account of the Deafmute Institutions in the Dominion, and a Description of all Known Finger and Sign Alphabets (Toronto: Howe, 1888), 48. (https://archive.org/details/deafmutesofcanad00howeuoft/page/48/mode/2up). ${ }^{54}$ Bill Bynum, "Maternal Impressions," The Lancet 359 (March 9, 2002): 898.

55 "Millie Fulton," App \# 460. Admission Applications, 1890-1939, PAM.
} 
Gertrude's mother reported that her "sympathy with a deaf child" caused her daughter to be born deaf, while a doctor seems not to have been consulted by her parents. Other parents reported that their children were deaf because their mothers were startled during pregnancy, and another reported that the sight of blood during a mother's pregnancy caused her child's deafness upon birth. ${ }^{56}$

Strange causes were also given for acquired deafness in youth, rather than in utero - often because of startling. Terry Williams's cause of deafness, in a form filled out by a family friend but signed with his father's "x," was reported as occurring at the age of two. "When he was two years old," the form states, "was frightened by a dog was ill and delirious for 5-7 weeks not spoken since. ${ }^{, 57}$ Despite the above stories told by parents to absolve their families and themselves of a perceived stigma, MSD clerks would likely only write "hereditary" or "no cause" in student attendance ledgers. Duncan McDermid, however, did pay careful attention to the prevalence of consanguity among parents, as did other North American principals in the late nineteenth-century. These stats were kept and published periodically in the American Annals of the Deaf to argue against proposed bans of deaf marriage and disproving consanguity as a cause of deafness, rather than a serious attempt to work against marriage within deaf communities.

Vocational education was a central platform in convincing hearing parents that deaf schools were an asset to their children's integration into liberal versions of futurity. As Alessandra Iozzo has argued, students at the Ontario Institution for the Education of the Deaf and Dumb were trained not only as provisional political citizens, but also as

\footnotetext{
${ }^{56}$ App \# 516. Admission Applications, 1890-1939, PAM.

57 “Terry Williams," App \# 575. Admission Applications, 1890-1939, PAM.
} 
adults who could provide for themselves and others within a liberal economic order. ${ }^{58}$ Vocational education was gendered, with most deaf school curriculums in North America offering printing, carpentry, or shoe repair for boys, and dress altering and domestic service for girls. As a whole, deaf school vocational curriculums offered futures in lowly paid artisanal or bonded work, with the exception of boy's printing, which offered the possibility of an income that could pull a worker off the margins, at least eventually. In many schools, these programs were geared to support the financial subsistence of the institution itself, with girls' training involving school washing, and boys' tasks including making shoes for inmates at other provincial institutions. ${ }^{59}$ These programs were, for the most part, about avoiding dependency on family, community, or state. They concretely reflect a reaction against shared dismal conceptions of disabled and deaf futurities.

Vocational programs began for boys at the MSD in 1892, with the acquisition of a printing press, and an agreement with a deaf Winnipeg printer named Agnes McIntosh to instruct boys at night, after his shifts at the Free Press. Girls' vocational programs began earlier at the school, but were initially only programs that trained girls in laundering by contributing their labour to provide the school itself with service. After Duncan McDermid took over from J.C. Watson in 1890, this practice was discontinued and the school matron began to teach seamstressing and domestic service, while outside contractors washed the school's laundry.

\footnotetext{
${ }^{58}$ Iozzo, "The Education of 'Good' and 'Useful' Citizens: Work, Disability, and d/Deaf Citizrnship at the Ontario Institution for the Education of the Deaf, 1892-1902," in Untold Stories: A Canadian Disability Histories Reader, edited by Nancy Hansen, Roy Hanes, and Diane Driedger, 66-90. (Toronto: Canadian Scholars Press, 2018).

${ }^{59}$ Iozzo, "Good and Useful Citizens," 70.
} 
McDermid and the new MSD printing instructor, a deaf printer named J.R. Cook, began Silent Echo to serve both as a school newspaper to connect parents to students, but also to provide evidence of the vocational training that boys were receiving. Initially published once a month, it became a bi-monthly publication that was dated the first and fifteenth of each month of the school year. By the end of the 1890s, Silent Echo began to not only perform the work of a connective tissue between parents and students, but also to deaf people within Winnipeg and around the Prairies, as we will see in Chapters Five and Seven. The idea of a school newspaper that performed these functions was hardly unique to Manitoba, as virtually all other North American deaf schools had printing programs for boys and a newspaper in which they could gain practical experience. These "little papers" were connected in a continental and trans-Atlantic relationship where they would trade news, developments in deaf education, and views about the dominant issue of the period - the methods debate. ${ }^{60}$

Indian Residential Schools throughout North America had similar programs that sought to inculcate a sense of citizenship, patriotism, and self-sufficiency in a liberal order. Boys at many Canadian and American schools were taught to internalize these abstractions through printing programs and through the production of school newspapers. Jane Griffith's work on North American Indian Residential School papers outlines some key features that both align and appear in contrast to deaf school papers. ${ }^{61}$ Both types of school papers were produced for external production and to try to foster links between student and home, and were heavily edited by educators. The differences are central,

\footnotetext{
${ }^{60}$ Beth Haller, "The Little Papers: Newspapers at Nineteenth-Century Schools for Deaf Persons" Journalism History 19, no.2 (1993): 43-49.

${ }^{61}$ Jane Griffith, Words Have a Past: The English Language, Colonialism, and the Newspapers of Indian Boarding Schools (Toronto: University of Toronto Press, 2019), pp
} 
though. Deaf school newspapers became, within limits, documents that fostered the growth of a nascent deaf community, through the publishing of deaf society minutes and political initiatives. Deaf school newspapers also allowed male graduates an expectation of employment in the trade, as many graduates of the MSD were hired at newspapers in Prairie towns and cities, while Indigenous graduates were rarely hired. Indeed, Griffith can only identify one Canadian Residential School graduate obtaining employment at a newspaper. $^{62}$

Silent Echo (and after September 1914 The Echo) was intended in part to serve as a connection between students and their communities all over Western Canada. Throughout the period under study, the paper dedicated an entire page to news provided by students about themselves, other students, or visits around Winnipeg. Each year, pages were devoted to news from each of the four Western Provinces, with published photographs of groups of students from a given province together. The paper, then, forged and maintained links between the MSD and distant families, as well as the MSD and deaf communities in Winnipeg and throughout Western Canada. These links overlapped with the dual identities of deaf people in hearing families - straddling hearing and deaf communities.

The Echo published a section called "Pupil's Locals" for much of the time under study, as well as "Local News" and "City News." These sections kept parents appraised on the activities and work done by their children in Winnipeg, including sporting events, examples of writing assignments, visits from relatives, and students' opinions on local

\footnotetext{
${ }^{62}$ Griffith, Words Have a Past. It is important to not take this point too far. The 1901 and 1911 Canadian censuses show that deaf employment in printing was higher on the Prairies than anywhere else in the country.
} 
and world events. In the December 2, 1912 edition, the "Pupil's Locals" page remarked that "some of the boys went to the Bazaar at the Eaton's store on Saturday afternoon. They were delighted with the toys," as well as "we are tired hearing about the war in the Balkans and wish it would end." ${ }^{, 63}$ The paper would also print examples of student writing and provide parents with news on students who had become ill or injured. Parents were also notified of schedule changes, like the shortening of the 1918 Christmas break due to time lost during the influenza pandemic. ${ }^{64}$ This section also took on a regional focus, with frequent "Students from Alberta" sections that often featured group photos of Alberta students, or sections containing news from communities in Saskatchewan with large representations at the school, like Lipton, Saskatchewan, which had a large deaf population. ${ }^{65}$

${ }^{63} S E$ 21, no. 2 (December 2, 1912): 3, LLM.

${ }^{64}$ The Echo, 26, no.3 (December 15, 1918): 3, LLM.

${ }^{65}$ We will consider Lipton's links to the MSD in Chapter Five. 


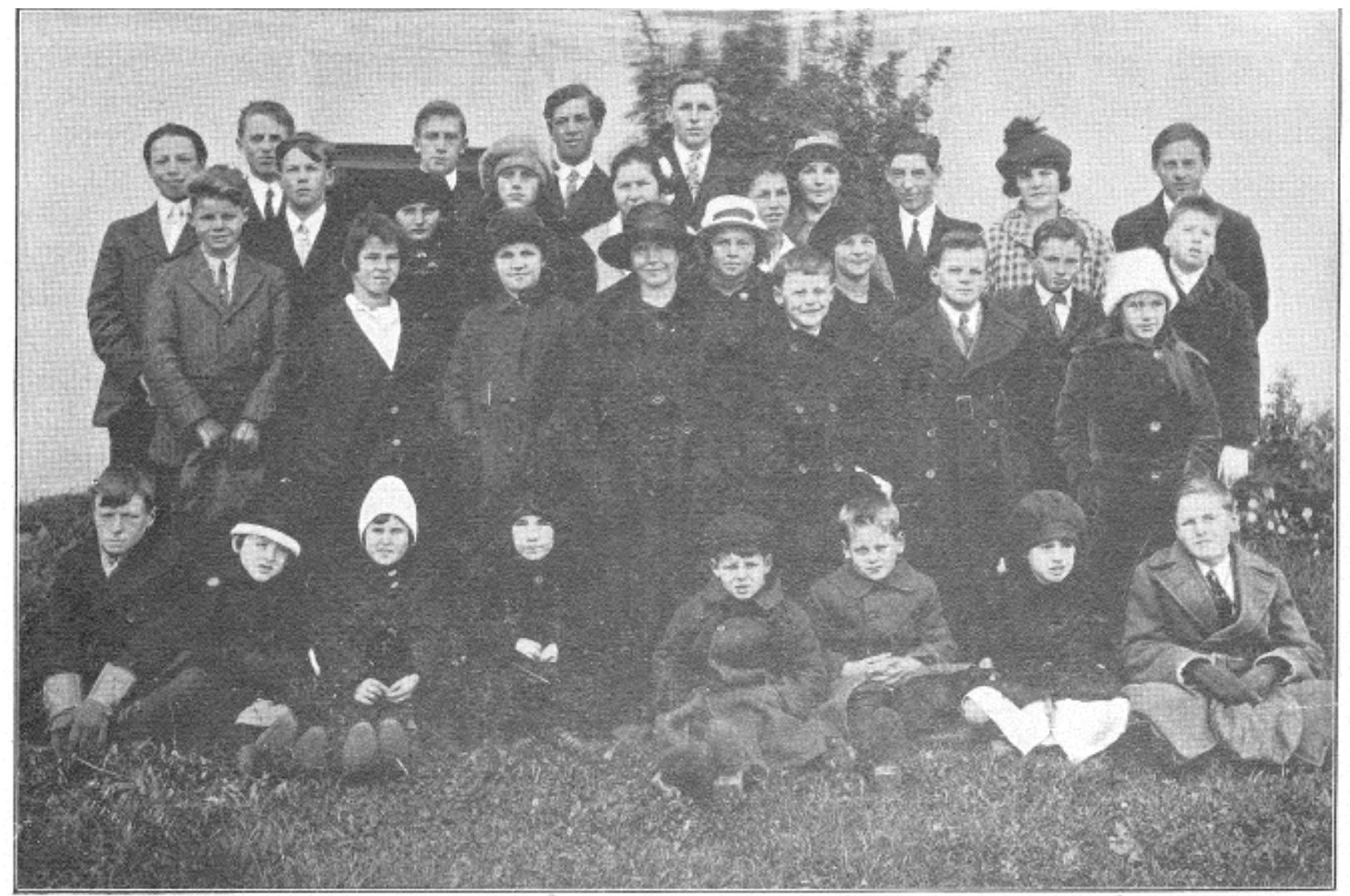

PUPILS FROM THE PROVINCE OF ALBERTA

Figure 4.1 - Students from Alberta, 1920. Echo 28, no. 2 (November 15, 1920): 3.

The Echo, and its editor J.R. Cook, explicitly included these visual and anecdotal links to parents to help ease parental anxiety about spending so much time without their children. This was openly addressed in a 1925 editorial. "We realize what it means," new editor D.C. Tomlinson wrote,

for parents to be separated from children, in some cases for nine months of the year, and they too realize that an education, so necessary to a hearing child, is much more necessary for one who is without the sense of hearing. They have trusted us so far as to place in our hands the care and education of their children. We appreciate our responsibility, and assure them that those whose duty it is are doing their utmost to carry out the work for those which the school exists. The parting between parent and child was in some cases trying to all concerned, but if 
parents could now see how happy their children are and how cheerfully they take to their new life, they would have little anxiety. ${ }^{66}$

Printed pictures of their children, as well as their children's discussion of new friends and their city activities, were likely meant to assuage parental fears and try to keep children and parents connected. The paper also performed the task of presenting a rosy view of life at the school to calm parental fears and assure taxpayers, as well as the Alberta and Saskatchewan governments, that the institution represented public money well spent. These images, also, never did show representations of signing, although signing was common in dorms and common areas, with finger-spelling preferred in manual class settings. This allowed the school to avoid an outcry from hearing parents who were, by the 1920s, increasingly hostile to sign language education.

The MSD and emerging deaf communities on the Prairies struggled, from the 1890s to the founding of the Saskatchewan School for the Deaf in 1931, to manage and channel the hopes and fears of hearing parents into support for a state-supported deaf educational system. Provincial governments and educators focussed on fostering a new vision of deaf futurity that could combat popular public conceptions of disability as tragic and a marker of a "dependent" status that pushed deaf people outside of an imagined liberal order. These efforts were often humanitarian in nature and, at times, at odds with the wishes and preferred representations forged in deaf communities and families. As we will see in Chapter Seven, deaf organizations were able, by the 1920s, to use liberal and state-building rhetoric to push their own conceptions of educational rights and tax-paying citizenship beyond those offered by the provinces and hearing public.

\footnotetext{
${ }^{66}$ Echo 33, no. 1 (October 15, 1925): 4, LLM.
} 


\subsection{Medical Care and Death at the MSD and Home}

Canadian medical historians have pointed to this period as one of increasing prestige of medical practitioners, and increased medical care. ${ }^{67}$ This increase in medical intervention was also achieved through basic increases in the provision of rural healthcare in the 1920s, as many of the children represented in MSD applications had never seen a medical professional in their lives. Deaf children of hearing parents were increasingly taken to audiologists in Canada and the Mayo Clinic in Rochester, Minnesota, after the First World War. The MSD itself pushed along this increased reliance on professional opinion during the First World War, as Howard McDermid, a young medical doctor who took over as Superintendent for his deceased father in 1909, begun to require doctor's attestations on forms.

Most of the children whose applications suggested they lacked access to basic medical care before the 1930s were rural Eastern European immigrants, and were overwhelmingly Ukrainian, Russian, Polish, and Mennonite. Of 398 applications from the NWT and Saskatchewan/Alberta from 1897 to 1931, 78 were recent immigrants from areas of Europe now encompassing Ukraine, Poland, Russia, and Romania, and six were from Mennonite communities. ${ }^{68}$ Children who had been to a doctor, or had some kind of surgical intervention, were largely English-Canadian or English-American immigrants. These distinctions persist until the end of this study in 1931, though there are groups who

\footnotetext{
${ }^{67}$ Commachio, Cynthia, Nations Are Built of Babies: Saving Ontario's Mothers and Children, 1900-1940 (Montreal and Kingston: McGill-Queen's University Press, 1993, 109-110.

${ }^{68}$ Admission Applications, 1890-1939, PAM. The nationalities of these students were identified by either their ethnicity stated on the application form, or from their surname. The more common ethnicities stated on the forms before 1931 were Ruthenian, Galician, Russian, or Romanian. These numbers are, at best, a decent approximation. By 'recent' I mean first or second generation by recent Statistics Canada definitions.
} 
fall inside and outside of these distinctions, like German immigrants, French Canadians, and Scandinavian immigrants.

The early twentieth century certainly saw the confirmation and propagation of what Disability Studies scholars call "the medical model" of disability, ${ }^{69}$ meaning that disability was commonly seen as an inevitable outcome of impairment, and that impairments had solely medical causes and "cures." ${ }^{, 70}$ Surgical and specialist intervention for deafness began to show up in application records by the early twentieth-century, with cases becoming more common after 1910. As Jaipreet Virdi-Dhesi points out, it took generations for audiologists to overcome the stigma of early modern and eighteenthcentury experimentation with untested and harmful treatments on deaf people and children. ${ }^{71}$ Parents increasingly sought regional surgeons and specialists in Regina, Saskatoon, Calgary, and Winnipeg in the early twentieth-century, with the practice becoming more common in North America by the $1930 \mathrm{~s} .{ }^{72}$ Surgeries usually involved the removal of adenoids and were reportedly ineffective. Between 1900 and 1931, fourteen applicants reportedly received regional specialist care, with all but one example being before 1914. These visits were invariably reported by parents or guardians as attempted cures that had had little or no effect.

Eight other applicants had been seen at the Mayo Clinic in Rochester, Minnesota between 1918 and $1928 .^{73}$ The Mayo was a pioneering force in group practice, which

\footnotetext{
${ }^{70}$ Withers, Disability Theory and Politics, 31.

71 Jaipreet Virdi-Dhesi, “Curtis' Cephaloscope: Deafness and the Making of Surgical Authority in London, 1816-1845," Bulletin of the History of Medicine 87, no. 3 (2013): 347-377.

${ }^{72}$ Veit Erlmann, Reason and Resonance: A History of Modern Aurality (Cambridge: MIT Press, 2010).

${ }^{73}$ The Mayo Clinic was founded in 1864 by W.W. Mayo, but did not become a large clinic that drew patients for specialist care until the late 1890s. It became a not-for-profit institution in 1919.
} 
allowed a team of doctors to specialize at the clinic and in patient care. Audiology was one of these specialties, and Mayo became recognized as a leader in the field by the end of the First World War. ${ }^{74}$ Applicants who had been treated at Mayo were overwhelmingly English Canadian or American, based on surnames and claimed "nationality" on applications. ${ }^{75}$ While the numbers seeing both regional specialists and doctors at the Mayo Clinic were fairly small, they do represent that for fairly affluent hearing families, attendance at a deaf school was often a last resort, after medical intervention had failed to restore or give hearing to their children.

Once in attendance at the MSD, students received care from a live-in nurse at an infirmary built at the Sherbrook St. location after the 1892 death of a student from scarlet fever. During the time under study, sick students were kept at the school, rather than being sent to the hospital unless they were gravely ill. Students sent to the hospital for scarlet fever or other infections often deteriorated there, like Judy Wilson, the Indigenous girl discussed in the previous chapter who died at the Winnipeg General Hospital of a tuberculosis infection after having contracted scarlet fever. Fifteen students died while enrolled at the school, though five of those died while at home on summer holidays. ${ }^{76}$ Most deaths were due to scarlet fever, measles, or diphtheria, and all deaths occurred between 1892 and 1921, with one death being accidental.

These deaths were extensively commented on in The Echo and Winnipeg papers. At Fred Lonsdale's 1892 funeral, prominent local figure and author Rev. Charles Gordon

\footnotetext{
${ }^{74}$ Bruce Fye, Caring for the Heart: The Mayo Clinic and the Rise of Specialization (New York: Oxford University Press, 2015), 7-8.

${ }^{75}$ Many respondents to this question did not simply write "Canadian" but "English" or "English Canadian."

${ }^{76}$ This includes the years 1888-1931. Of those ten who died while residing at the school, five were from Alberta, Saskatchewan, or the Yukon. Record of Pupils 1-374, 1889-1928. Books 1 and 2. A0061 GR 1635 G 109 Box 1, PAM.
} 
gave a sermon. ${ }^{77}$ Most students were celebrated in The Echo on the tenth anniversary of their deaths. The death of a student was treated as a tragedy at the MSD, and investigations were undertaken for most deaths at the school or hospital. Given the amount of alarm that Duncan McDermid expressed to the Manitoba government about overcrowding, ten deaths in thirty-four years, and no deaths at the new MSD location from 1922-1931, seems remarkably low. An important caveat to this conclusion, though, is that the level of detail offered in the Student Attendance Book after 1922 declines, and there are two students who were simply marked as "deceased," without reference to whether they died at the school or after graduation. ${ }^{78}$

Medical care and overcrowding were constantly on the minds of Principals Duncan and Howard McDermid. After the death of William Lomas of British Columbia in December of 1910, Howard McDermid wrote a wrenching paragraph in Silent Echo. "It is with great regret," he wrote

that we announce the death of one of our pupils, William H.E. Lomas from Duncan's, B.C. He contracted a malignant case of Scarlet Fever and expired after four days illness in spite of every care and treatment that could be devised. This severe case coming after our mild epidemic shows that we are never sure of the trend of this treacherous disease and emphasizes most strongly the need of a separate hospital building where we can isolate suspects and the recent fever cases. Also it makes us feel that the extreme overcrowding of our institution is in a good measure to account for the prolonging of the epidemic. ${ }^{79}$

While cold in tone, the act of writing this paragraph, in a newspaper sent to families of students and heavily subscribed to deaf Western Canadians, should be seen as incendiary on Howard's part. Whereas his father, in 1893, had aired his anger in private

\footnotetext{
${ }_{77}^{77}$ Gordon published popular novels under the pseudonym Ralph Connor.

${ }^{78}$ Record of Pupils 1-374, PAM.

${ }^{79}$ Silent Echo 19, no. 6 (December 15, 1910), 3. LLM.
} 
correspondence with Public Works, Howard was doing it in public. The Sherbrook buildings, always overflowing and already out of date, were closed within three years, and the school moved to the University of Manitoba until a new larger school could be built.

The Echo also published more emotional accounts after student deaths. February and March of 1919 were difficult months for the MSD, as they saw the deaths of two first-year students, Jacob Haus of Quinton, Saskatchewan and Carl Hoskins of Tadmore Saskatchewan. Haus died after sliding down a spiral bannister and falling through the staircase. The six-year old Jacob's brother, John, was also a student at the MSD between 1917 and 1924. The Echo notes that "the inquest held by the coroner's jury returned a verdict of accidental death, exonerating the school authorities of all blame," likely trying to reassure parents who were seeing two obituary pieces in the same issue. ${ }^{80}$ Jacob's body was returned to his parents in Quinton with letters written by friends as well as floral arrangements from the school's teachers. J.R. Cook, The Echo's editor, described Jacob as "a bright and promising pupil," a description that perhaps betrays his own unfamiliarity with the new student. He did, however, describe Jacob's injuries and the circumstances of his discovery in an amount of detail that seems not only inappropriate but also surprisingly transparent. "When found," Cook wrote,

his body was badly bruised and his skull was fractured. It seems that he either fell down the stairs or lost his balance while sliding down the stair-railing. The boys have often been cautioned to keep off the railings, which bound four flights of stairs to the floor of the boy's dormitories. The supervisor Mrs. Lafquist heard his cries and hastened to his assistance but he died a short time afterwards.

${ }^{80}$ The Echo 26, no. 6 (March 15, 1919), 4. LLM. 
The school, clearly, felt shielded from criticism for Haus' death because of the ruling of the inquest. The March 1919 death of Carl Hoskins, with The Echo printing numerous tributes and accounts, will be dealt with in detail in Chapter Five, as the Hoskins were one of several deaf families from south-eastern Saskatchewan, a region that will form the focus of much of that chapter.

In the one pertinent case, school perspectives on the tragedy or inevitability of death at the school adhered to boundaries around settler/Indigenous identities in interesting ways. The earlier death of Judy Wilson gives us an opportunity to analyse the coverage of the death of an Indigenous child over a full decade, as The Echo published a memorial essay upon the tenth anniversary of her death. Wilson, as described in Chapter Three, had been found "orphaned at an Indian camp" in the Yukon and adopted in 1902, and was sent to the MSD in $1904 .{ }^{81}$ She became ill with typhoid fever in late 1906, was hospitalized, and died shortly afterwards from a tuberculosis infection that took advantage of her weakened immune system. In his Annual Report for 1907, Duncan McDermid framed her death from tuberculosis as inevitable, writing that "being a fullblooded Indian, and like the majority of her race, seemed predisposed to tuberculosis, she did not give any evidence of resistance during the rapid development of the disease." ${ }^{\prime 2}$ There is more than simple racial stereotyping in McDermid's words here - there is a kind of abrogation of responsibility for Wilson's death due to her Indigeneity. She was the first Indigenous student at the MSD, and McDermid portrayed her as visibly different

\footnotetext{
81 “Judy Wilson,” App \# 150. Admission Applications, 1890-1939, PAM. I will keep using her pseudonym, although she is identified in the primary sources used in the following discussion, because she is discussed extensively in publicly available sources and those governed by my agreement with the Province of Manitoba.

${ }^{82}$ Duncan McDermid, “Annual Report for the Institute for Deaf, Dumb, and Blind (sic),” Alberta Department of Education Reports, 1908, 60. Alberta Legislative Library (ALL).
} 
from settler students, though he "did not think she ever had the occasion to feel by any treatment by her playmates or others that she was different in colour than other children., 83

A 1916 piece entitled “The Indian Girl's Prayer,” written by a Reverend R.O. Armstrong and published on the first two pages of the May 15 issue of The Echo, has a very different depiction of what Judy meant to the school ${ }^{84}$ Armstrong begins his story with a traveller who hears the cries of two children in the Yukon backcountry, and follows his "fountains of pity" to save these children that had been "abandoned by their people. ${ }^{„ 85}$ The prospector, despite his wish to move on in search of his fortune, sees "an opportunity for real self-denying service," a chance to enrich himself spiritually if not financially. ${ }^{86}$ Wilson was left at the nearest church, taken with her brother to B.C., and eventually sent to Winnipeg alone to attend the MSD. While at the school, she found both comfort and alienation. "Happy as this scene seems to be," Armstrong wrote,

there is something troubling one of the pupils. The Indian girl has at last become conscious that her face is a different color from those around her... She thought that the children with white faces got more favors than she did... at vacation time all the other children went away. Why did she not have a home to go to like the other girls? She thought it was because she was black. ${ }^{87}$

One evening, Wilson signed to the matron, asking if God could do anything she asked him for. After the matron signed positively, she went to her room. "That night a new prayer was heard in heaven," Armstrong wrote. "It marked the dawn of a new faith in a soul. It marked a new epoch in the history of a race. The Indian girl prayed to be

\footnotetext{
${ }^{83}$ Ibid.

${ }^{84}$ It seems very likely that this R.O. Armstrong is Rupert Otto Armstrong, a Methodist Minister in Kenora, Ontario in 1916. Howard McDermid had a cottage in the Kenora area.

${ }^{85}$ The Echo 24, no. 15 (May 15, 1916), 1.

${ }^{86}$ Ibid.

${ }^{87}$ Ibid.
} 
white. ${ }^{88}$ Armstrong was interrogating not what Judy meant to the school, but what the school meant to her as an Indigenous person that could be transformed by it.

Wilson's prayer seemed not to be answered by God the next morning. Shortly afterward, she was sent to the hospital, where she deteriorated. Signing to the nurses that "she was going to see her brother," she died quickly. Armstrong's final paragraph drives home the missionary impulse behind the piece. "Many of her silent playmates went to her funeral," he wrote, "and sought to glance once again on the face that they had learned to love. How strange was the report they all gave. With self-repressed excitement they signed to one another 'changed.' It was not the natural way. What could it mean? Again the prayer of (Judy Wilson) was answered. Her face was white." ${ }^{89}$

The piece is riven with depictions of Wilson's physical difference, with its social and spiritual implications. Her fellow students "learned to love" her face, the implication being that such a dark face would take effort to be accepted socially. Armstrong suggests that the only true transformation available to Indigenous people was spiritual, and that transformation through schooling would be incomplete, leaving Indigenous students to hold on to the culture of selfishness that led to Wilson and her brother being abandoned by their parents. ${ }^{90}$ Even after being accepted at school, Wilson could only ever become white through death. This parable positioned the prospector, Church officials, and the educators at the MSD as humanitarians who gave themselves to the difficult project of forging "civilization" from a "wild" girl.

\footnotetext{
${ }^{88}$ The Echo 24, no. 15 (May 15, 1916), 2, LLM.

${ }^{89}$ Ibid.

${ }^{90}$ Application records show that her parents had died, and she and her brother were not abandoned.
} 
It is important to again make the point that deaf people, and emerging deaf communities, were implicated in the Canadian colonial project. J.R. Cook, the deaf editor of The Echo, chose to print this piece, though we cannot be sure how he felt about it. It is very likely that he saw it through the same settler-humanitarian lens as Armstrong. Both McDermid and Armstrong's views are racist depictions of settler attitudes toward Indigenous identity and futurity - McDermid's vision of cold biological racism is an easy companion to Armstrong's denial of Indigenous spirituality. In both visions, death is inextricably linked with Indigeneity and completes a full circle that chokes off possible indigenous futures. Both embrace common early twentieth-century "disappearing Indian" tropes and draw teleological meaning from them. ${ }^{91}$ Yet both are also touching and tender, betraying real feeling for Judy. This circle of humanitarianism - the need to save one who cannot save themselves - was very close to the yoke being thrown off in the 1920s by deaf Canadians who pushed a liberal futurity in the service of deaf children, as we will see in Chapters Five and Seven.

With the borders of deaf identity in Canada still being negotiated and explored, Judy's Indigeneity made her a difficult subject for the school to fit under the discursive umbrella of white settler deaf Canadian. No details were given, in 1907's Silent Echo or 1916's Echo about Judy's burial arrangements, except that she was buried in Winnipeg, as she was, it seems, not fully adopted in British Columbia before her move to Winnipeg. Armstrong's story suggested that although she had a brother, she stayed in Winnipeg year-round because there was no place for her to go home to. This made Judy one of only

\footnotetext{
${ }^{91}$ The "disappearing Indian" was a common nineteenth-century trope, in which Indigenous people were seen as threatened by modernity and citizenship, meaning that the colonial process was temporary because Indigenous people would either "die out" or become Canadian citizens. Indigenous people were often depicted in nineteenth-century literature as unable to survive modernity, because they themselves were products of a kind a backward evolutionary state aligned with nature.
} 
two students who died at the MSD to not have their bodies repatriated to their home community. This is perhaps understandable, because Judy, unlike other children at the MSD or other Indigenous girls at Indian Residential Schools, was on her own side of the border demarcating the futures available to white settler deaf and Indigenous deaf children.

It is apparent, however, that past comparisons of deaf residential schools to Indian Residential Schools falter badly here and in other respects. ${ }^{92}$ Viewed through a wide lens, we can contrast deaf residential schools as sites of cultural formation, rather than cultural destruction, like IRS. While deaf schools did have cases of sexual and physical abuse, and generations of students were denied the use of sign language, deaf people themselves used schools to find community in often difficult circumstances. Deaths at IRSs were extremely common, rarely documented, and never answered for. ${ }^{93}$ As we see in the discussion above, this was not true for deaf schools. Regardless of the importance of hearing people's ignorance and denial of basic rights to deaf students and their families, settler identity ultimately mattered, and deaf settler Canadians were clearly on the side of the settler-Indigenous divide that afforded them the privilege of being seen as human, unlike Indigenous children during the time under study, who were experiencing one of the harshest periods of the long genocide pursued by the Canadian Government against Indigenous peoples.

\footnotetext{
92 These are few and include one Canadian Master's thesis and popular blog posts. Paddy Ladd makes this comparison, as well as to the Holocaust, in his work. See Understanding Deaf Culture: In Search of Deafhood (Bristol, Channelview Publications, 2003), 29-31.

${ }^{93}$ Truth and Reconciliation Commission, Canada's Residential Schools: The Final Report of the Truth and Reconciliation Commission of Canada (Montreal and Kingston: McGill-Queen's University Press, 2016).
} 


\subsection{Calling Upon the Doctor, Calling Upon the Government}

As we will see in Chapter Six, many parents turned to doctors for guidance in educational opportunities for their children who were unable to attend public school for a number of reasons, and doctors often pushed them to apply to the MSD, whether they were deaf or not. In this section, we will look more closely at what parent interactions with community figures says about contemporary constructions of deafness, and how doctors and citizens understood the emerging "special education" field that accepted students who fell under the "dependent" label.

Application forms from Alberta and Saskatchewan before the First World War show that parents initially sought guidance from community leaders - clergy, local officeholders like postmasters, local elected officials - rather than doctors. This changed slowly after Howard McDermid changed application forms to explicitly mandate a doctor's "attestation" to the child's fitness to attend school. While application records do not give us a full picture of the circumstances leading to parents' discovery of the availability of, and path to, education for their deaf children, they do allow for some clear generalities about a slow medicalization of disability in the $1910 \mathrm{~s}$ and $20 \mathrm{~s}$. The role of governmental coercion in children entering the deaf educational stream is far less clear, as is hearing parents' expectations for the methods that their children would be educated with - oral or manual.

Between 1894 and the end of 1930, 380 applications were received in Winnipeg from Saskatchewan, Alberta, and Yukon Territory. Of these, 268 were filled in and signed by parents, were unsigned, or were filled out at the MSD office. Most applications were, therefore, handled by parents themselves, and by the 1920 s, nearly all were. As we 
can see in Fig. 4.2, other applications were filled out by unknown others (neighbours, relatives, etc.), clergy, doctors, the $\mathrm{BCP}$, and the police. While the increase in doctorcompleted applications coincides with an overall increase in the number of applications, a few trends are discernable through this application data.

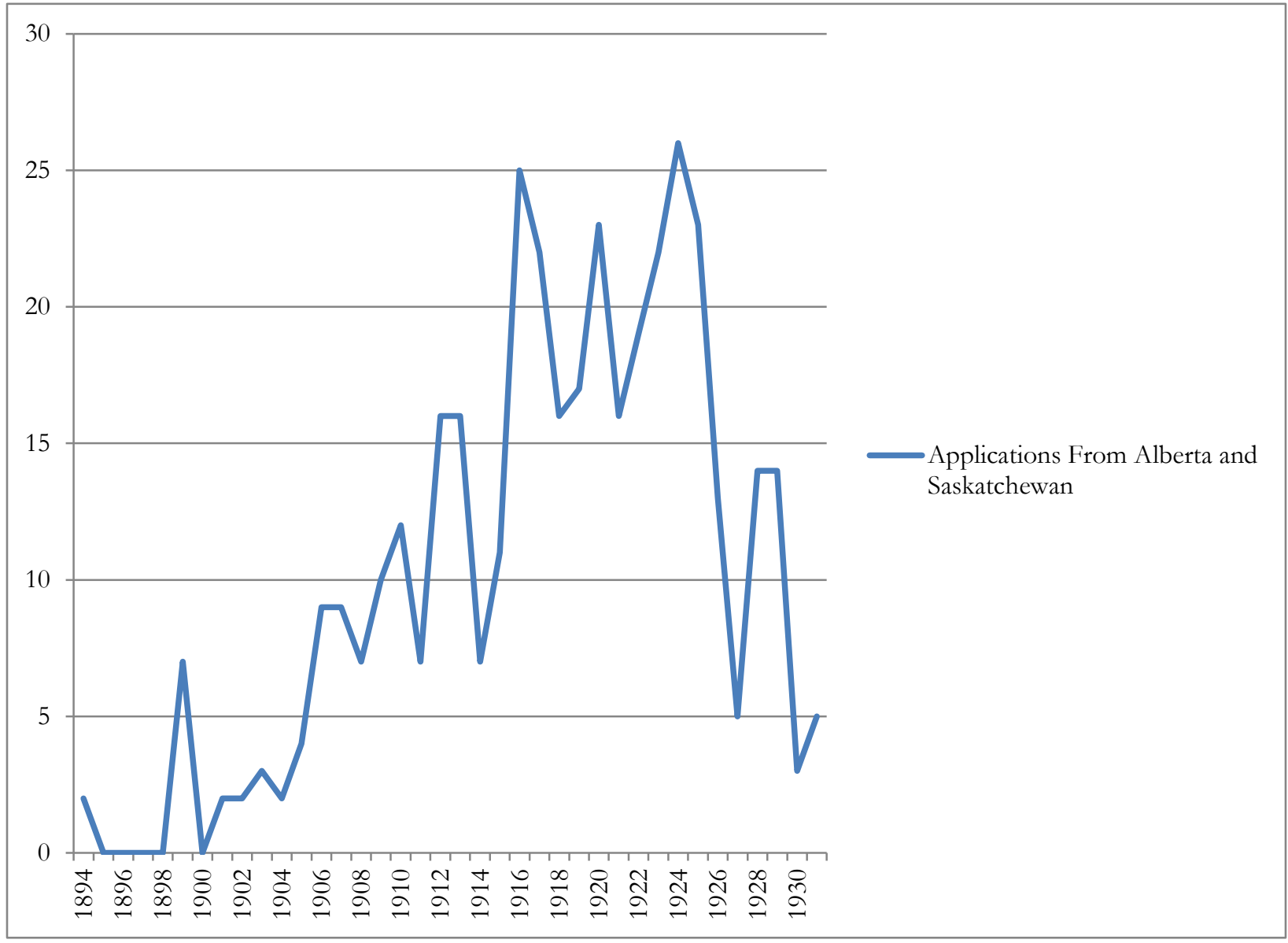

Figure 4.1 Applications from Alberta and Saskatchewan, 1894-1931. Source: Admissions Applications, 1890-1939, Ab-Zm, PAM.

From 1897 to 1915 , the most commonly reported first point of contact in parent's search for educational services for their deaf children was the clergy or medical 
professionals. Before the First World War these points of contact were largely equal, while after the War doctors and the BCP represent the largest number of filings undertaken by institutional figures. As we will see in Chapter Six, one principal reason for this was Howard McDermid's changes, brought into effect in 1915, to require a doctor's attestation on a child's fitness to be educated and "soundness of mind." By 1920, the number of applications with doctor's signatures and filled out by parents was near total. Another reason was an increased intervention by state and charitable actors in Canadian family life during the war. Though it cannot be concluded definitely from application records, the data suggest that before the War many parents sought out advice and instruction from religious leaders and local officials (reeves, mayors, postmasters, and J.P.s), while during and after the war parents encountered the state through the BCP, medical profession, or local schools.

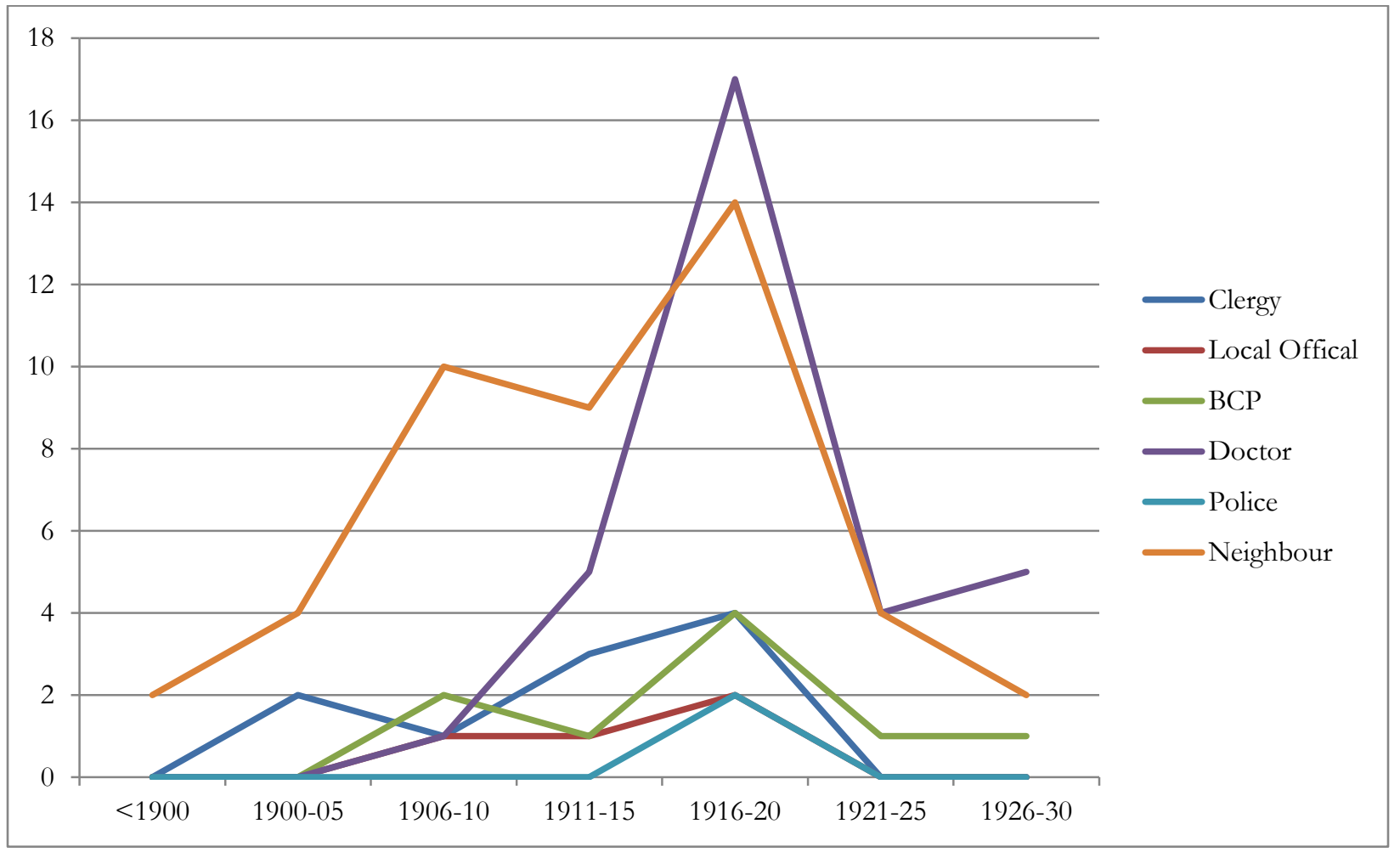


Figure 4.2 Trends in non-household member application filers by occupation. Source: Admissions Applications, 1890-1939, Ab-Zm, PAM.

Henry Wasilyski, from Senlac, Saskatchewan, had his 1928 application filled out by a community member and signed by a doctor, who forwarded it to the MSD. "Dear Sir," read the doctor's note accompanying the application, "I did not see this child. They live in the country. The people are strangers to me, having come here from Alberta. The application has been made out under the direction of A.E. Morton, and intelligent and reliable member of this community and a neighbour of (Wasilyski). I believe the report to be reliable and I can add nothing to it." ${ }^{.94}$ There were several examples of doctors giving their attestation, after 1915, without seeing the applicant themselves. Howard McDermid, and subsequent Superintendents, operated on medical faith that a doctor could be trusted, even if accounts were second or third-hand. This was necessary in a wide area where many applicants came from poor farming families whose children had never seen a doctor, or had only seen a travelling physician.

After 1915, hearing parents often encountered deaf education through local public school teachers. Many deaf or hard-of-hearing children attended public schools, as we have seen in Chapter Three. Applications give a picture of teachers who either strove to accommodate deaf children as much as they could, or advised parents to apply to the MSD. There are no examples of teachers filling out forms for parents, though it is likely that some did without stating their connection to applicants. There are examples of BCP officials filling out applications for Saskatchewan children, though these represent few cases, mostly during the War. The number of doctors, $\mathrm{BCP}$ officials, and police officers

\footnotetext{
94 “Henry Wasilyski," no app \#, 1928. Admission Applications 1890-1939, PAM.
} 
filling out applications points toward the presence of a growing coercion on families to send their children to school. The numbers involved, however, do not directly paint this picture in enough detail. While it is possible that $\mathrm{BCP}$ officials and police pressured parents who left no traces of this in applications, all $\mathrm{BCP}$ and police applications were for children who were already wardens of the state and under BCP or Children's Aid protection. There remained a high level of choice for families, given the number of children who remained out of school and the lack of intervention from the Saskatchewan BCP well into the 1920s. ${ }^{95}$ As we will see in Chapter Seven, there was a discernible trend in applications filled out by those later rejected by the MSD as "feeble-minded" - nearly all were filled out by doctors, who likely advised parents that their children's cases needed some medical translation to convince the MSD that applicants were "educable."

Applications often made clear that the children wanted to go to school, and that those deaf children out of school disrupted domestic life at times. Twelve year old Alma Foster's father filled out an application for her in 1916, after her mother was placed "in an asylum for the insane." Alma's father reported that "she is often left at the house a lone when I am away and the other children is at school." ${ }^{, 96}$ Karen Gzowski's application, filled out by someone outside of her family with her father, reports that "she seemed to be happy and is willing to go.... and is very anxious to learn to read and write. She even practices this herself without anybody's help. ${ }^{97}$ Karen was fifteen at the time of her application, and had been working on the family farm with her parents, who had five surviving children of eleven born. Carol Jones' mother reported that she had received a

\footnotetext{
${ }^{95}$ Admission Applications 1890-1939, PAM.

96 “Alma Foster," app \# 424. Admission Applications 1890-1939, PAM.

97 "Karen Gzowski," app \# 473. Admission Applications 1890-1939, PAM.
} 
letter from either the MSD or the BCP, making her 1916 response an application. "We should be very grateful," she wrote, "to benefit our daughter in some way and would very much like to get her into a school where she would learn something... she can say lots of words and explain colors or anything she wants to her sister who seems to understand her remarkably well...She has been to school with sister more for company than anything and is able to copy anything. ${ }^{.98}$ In 1928, George McKenzie of Saskatchewan wrote to R.J.D. Williams of the WCAD about the social complexities involved in familial decision making:

Recently I fear the boys have biased him and does not want to go and I do not feel it wise to press it, he is quite responsible and drives and handles horses, he no doubt is smart and has ability and if given some training will justify it, I find he wants to roam and have difficulty keeping him at home, no doubt his brain calls for work and it likes that form. He is a very healthy boy and it is too bad he has had no chance before, and I pray something may be done for my poor boy. I do hope we shall have a school in Saskatoon, it would be possible for us and our children from time to time but Winnipeg is so far for poor farmers. ${ }^{99}$

Parents did not report any serious unwillingness to attend school in application forms, however, though there was undoubtedly self-editing at play, and applications were modified by doctors to erase admissions of masturbation, tobacco use, and incontinence all of which could jeopardize the success of an application.

Hearing parents rarely mentioned a preference for manual or oral instruction. Several parents reported that their children used "signs" to communicate, but it is unclear what they meant by that. From context, it appears that hearing parents referred to gesture as synonymous with signs, in accordance with the late-nineteenth/early-twentieth century

\footnotetext{
98 "Carol Jones," app \# 486. Admission Applications 1890-1939, PAM.

${ }^{99}$ George McKenzie to R.J.D. Williams, March 12, 1928, 2-3. R.J.D. Williams Papers, Box 1 Correspondence, UAA.
} 
tendency to refer to "natural sign language" - a system of gestures that many understood to be an evolutionary relic of a form of communication that bridged "animal" and "human" stages in human development. ${ }^{100}$ Parents sometimes reported that their children "read better by signs," or understood "anything by signs." 101 There were few parents who explicitly asked for, or even referred to speech training, though by the 1920s it was likely assumed that this would be an important part of their children's educations.

Hearing parents, though appearing disinterested in the methods debate, could have very nuanced views on sign languages. Mrs. Thomas Stephens, in a letter to the WCAD's Williams, wrote that "She is very bright and intelligent and can make us understand by her actions all she wants. I have tried to teach her 'lip reading' but have not had much success...I have been advised to not allow her to make signs as this would make her slow to understand and use the lip reading but it seems to me most unnatural to try and check her only way of making us understand her."102 Mrs. Stephens employed a "naturalistic" view of sign language, but in a manner more empathetic to signing deaf people. While Stephens' views were rare among hearing parents in this study, the MSD and WCAD records suggest that by the early twentieth-century, the methods debate was rarely as out in the open as it was in the late nineteenth, and that both oralists and combinists tried to present their respective practices as natural or inevitable.

Parents were also vague on the issue of religious services for their children at the MSD. 123 applicants left the answer to this question blank, and four answered "none." While 219 applications did name a specific request for "religious instruction and services,

\footnotetext{
${ }^{100}$ Baynton, Forbidden Signs, pp

101 Admission Applications 1890-1939, PAM.

${ }^{102}$ Mrs. Thomas Stephens to R.J.D. Williams, October 19, 1927, 5. R.J.D. Williams Papers, Box 1 Correspondence, UAA.
} 
if available," many parents prefaced their choice with qualifiers like "if he can, he should go to ___ Church.” Twenty-four simply stated "Protestant." The parents of one ItalianCanadian student from Calgary answered that he "was too small to decide" his religious preference. ${ }^{103}$ Though the MSD provided religious services outside of the school only for Catholic and Jewish students who did not have family in Winnipeg and a nondenominational Protestant service in the school, there are no records of parental protest of this policy in The Echo or Department of Public Works/Education correspondence. The religious services requested for all students from Saskatchewan and Alberta between 1894 and 1931 represent a wide number of faiths and ethnic groups that made the MSD a fairly unique institution in the early-twentieth century - a school where spoken and written language instruction was assumed to be in English, an island from the aggressive and ever-present politics of school language instruction on the Prairies. ${ }^{104}$

There were only two exceptions to the unwillingness, or disinterest, of Alberta and Saskatchewan parents to challenge religious instruction at the MSD. Both were from Catholic parents who sought to send their children to one of the Catholic Institutions in Montreal. John Nagy's mother directly applied to the Catholic School for the Deaf Boys in 1929, which sent the application back to the MSD. ${ }^{105}$ The twelve-year old Saskatchewanian did enrol at the MSD that year, despite the fact that, as we will see in Chapter Seven, by the late 1920s most new Saskatchewan students were being sent to the MacKay Institution for the Deaf in Montreal. As in this case and another, the offer of separate Catholic instruction and service was enough to get initially wary parents to

\footnotetext{
${ }^{103}$ Admission Applications 1890-1939, PAM.

${ }^{104}$ Chapter Seven will explore the role of this uniqueness in the wake of the 1929 Saskatchewan election.

105 “John Nagy,” app \# 736. Admission Applications 1890-1939, PAM.
} 
accept membership at an institution that they likely saw as offering Protestant-lite religious instruction.

\subsection{Conclusion}

Saskatchewan and Alberta deaf or hard-of-hearing children whose hearing families applied to the MSD represented a wide breadth of cultural, linguistic, economic, and geographical diversity, where most religious and cultural minorities were represented between the 1890s and the 1930s. One glaring exception to this, as we have seen in this and the preceding chapter, were Indigenous students who were not on the "path to citizenship" as defined in the 1876 Indian Act. Hearing parents, based on a review of application records and available correspondence with the MSD and the WCAD, did not seem to reflect on the methods debate, though it is likely that many simply assumed that the school would offer oral instruction and began to agitate against combined instruction by the mid-1930s at both the MSD and SSD.

For many hearing families, the birth of a deaf child, or the deafening of a child through illness, was tragic. Hearing families often gave elaborate, or unbelievable, deaf origin stories to shield themselves and their children from the stigma of inheritance, especially by the 1910s. Hearing parents in Saskatchewan and Alberta were also poorly informed of the educational options for their children, and had to reach out to religious and community leaders, and increasingly doctors, to seek these out. In rural areas, however, farming families often instructed their children in the family business, worked out a form of home sign, and saw the farm or farm labour as their deaf children's future, much like the futures of their hearing children. 
While this chapter has staked out claims of change over the forty years it traverses, application records and correspondence gives an overall picture of stasis with respect to hearing attitudes toward deafness and deaf children. While Howard McDermid worked to medicalize the application process as much as he could during the First World War, rural distance, hearing disinterest in deaf politics and experience, and gaps in state formation led to the continuation of hearing prejudice and ignorance of possible deaf futurities. Many hearing parents did become involved in pushing for state expansion of deaf educational provision, but a recognizable distance between hearing and deaf families on the prairies persisted and deepened in the early twentieth-century. Hearing parents and state officials in Alberta and Saskatchewan were locked into looking at the deaf education issue through a humanitarian lens - looking to manage a problem by vague assurances of educational opportunity. The distance between the humanitarian and rights lenses became untenable in Saskatchewan by the late 1920s, at least in terms of educational access.

Hearing parents did perceive this distance between hearing and deaf perspectives at times, especially in 1920s correspondence with the WCAD. Most parents, in correspondence with R.J.D. Williams of the WCAD, referred to "your association" when referencing the group. Mrs. Thomas Stephens, in a 1927 letter, sounded out this distance by tentatively claiming membership herself, as a hearing parent of a deaf child. "My father was one of the real pioneers," she wrote to Williams, "and I feel that were I in 
Regina now, a few personal calls might help interest some of the business and professional men in your, or may I say our, Association."”106

${ }^{106}$ Mrs. Thomas Stephenson to R.J.D. Williams, 4. R.J.D. Williams Papers, Box 1 Correspondence, UAA. 


\section{Chapter 5 - "The Great Scramble of Men": Deaf Children in Deaf Families and the Emergence of a Western Canadian Deaf Community}

The deaf are never 'restored to society.' They are part of society at birth. They grow up and are gradually educated (more tediously to be sure) the same as all children. When they leave school they are thrown on their own resources in the same great scramble of men. While in the scramble they of course come in contact with all the people with whom their interests are entwined. This free mingling is the mingling of society, and when a deaf person goes out to make a living, he is not restored to society. He simply enters the larger and more serious sphere of society. Only criminals are restored to society. The deaf are not lawbreakers hence the word restoration as applied to them is an absurdity, if not an insult. ${ }^{1}$

The Echo, Winnipeg, 1919.

\subsection{Introduction}

Joseph J. Murray has argued that nineteenth-century deaf Americans saw themselves as part of American society - locally, regionally, and nationally. With the rise of oralism and its allusions to deaf "restored to society" through the acquisition of speech, and hearing fears of a "deaf race" in the early era of eugenics, deaf Americans not only turned inward into their communities, but outward to deaf communities across the Atlantic "for points of comparison they could not find at home."2 Western Canadian deaf emphasized an inward turn more than outward-looking in the first three decades of the twentieth-century, by first forming a local organization in Winnipeg that spread regionally, then advocating for deaf educational rights and publicity of deaf political and social concerns. As we have seen in Chapter Four, hearing parents, doctors, and community leaders often held an understanding of deafness as tragic and sought humanitarian responses that allowed productive futures for deaf children in a liberal era,

\footnotetext{
${ }^{1}$ The Echo 26, no. 6 (March 15, 1919), 4, LLM.

${ }^{2}$ Joseph J. Murray, “'One Touch of Nature," 3.
} 
or a fair shake in the "great scramble of men." Western Canadian deaf people also used liberal language to envision possible futures and the worth of individual deaf lives, while arguing that deaf education was a different, more specialized, and arduous undertaking. Expanded costs and attention to vocational training and advocacy on behalf of deaf workers were merely prices to be paid for provinces to assure that deaf children had an equitable educational right, and that deaf adults had had the opportunity to pull themselves up, like any other citizen.

This chapter will examine Western Canadian deaf education, and its legacies, from the perspective of deaf families and deaf communities themselves. Using WCAD correspondence, the deaf-edited (Silent) Echo, and MSD application records, it will trace the emergence of deaf rights activism and community in Western Canada from 1890 to 1931. These conceptual frameworks represented by the terms "rights" and "community" will be historicized, and I will argue that the former did become a term itself used by deaf writers while the latter emerged under the use of different terms. ${ }^{3}$ I will argue that deaf futurity was liberal and rested upon the individualized rhetoric of contemporary liberalism, but that it was also linked to notions of community, and I will examine Murray's term "co-equality" as an umbrella term for these seemingly contradictory facets of futurity.

I will also examine how Western Canadian deaf communities commemorated themselves and prominent individuals in North American and Canadian deaf history. How did deaf Canadians view the colonial project of Canadian westward expansion with

\footnotetext{
${ }^{3}$ Deaf writers in the WAD and WCAD often, as we will see, referred to "organized deaf" vs "unorganized deaf" as a way of identifying community, rather than using the more modern term.
} 
its practices of Indigenous displacement and genocide against Indigenous communities? How North American, or Canadian, did individuals consider themselves to be? What political causes, outside of educational access, did deaf groups take up, and did the WCAD act harmoniously or with inter-group disagreement? Of the first question, we can say at best with disinterest, and at worst with relish. Of the latter two questions, the answers are of course "both," but there are important cases to be made on both sides of these dichotomies that reflect important trends and ideas within deaf communities and deaf politics as they emerged in Western Canada.

This chapter will examine individual and linked deaf families in rural Alberta and Saskatchewan, before tracing the development of deaf communities that mostly shared local recreational fellowship before the First World War, and explicitly moved on to political activism in the early 1920s. Roughly, these developments correspond to the transition from the Winnipeg Association of the Deaf to the Western Canadian Association for the Deaf in 1921-22. After tracing some important commemorative moments in Western Canadian deaf history, as well as key political campaigns undertaken by the WCAD in the 1920s and 30s, I will examine the roots of the concept of "rights" used by the WCAD, and evaluating where they fit within the dichotomy of Canadian "liberal" and American "republican" conceptions of liberty. Finally, I argue that the resonance with strains of both conceptions of liberty that gather power from the notion of "individual freedom" were used by deaf communities to insist on the central importance of sign language transmission in deaf communities, and how the WCAD defined a border between deaf and disabled communities using sign language acquisition, 
helping to see deaf communities through a particularly difficult period of the eugenic era for deaf and disabled people.

\subsection{Deaf Families through Local and Regional Lenses}

Deaf families moved into Saskatchewan and Alberta with the wave of settlement that followed the post-1896 rise in displacement/settlement in the Canadian West. This section will identify and examine four deaf families and the deaf settlers around them one in Mayton, Alberta, and others in Lipton, Rosthern, and Tadmore, Saskatchewan. Clifton Carbin has written in detail on Lipton and the principal deaf families there, but I will continue this study's practice of using pseudonyms for children identified through the application records, through which my access is governed by an agreement with the Manitoba government. After some general demographics and discussions about three families and four localities, we will look at the emphasis on deaf marriage in (Silent) Echo and in MSD attendance records, and finally students from the region who attended Gallaudet College, the American deaf post-secondary institution in Washington, D.C.

Application records only give us a partial picture of the number of deaf families in Alberta and Saskatchewan between 1880 and 1931. Deaf parents had to first apply for their children, then claim on the form that they themselves were deaf, in order to become visible in application records. The (Silent) Echo offers us a picture of clusters of deaf families around Lipton, Saskatchewan, but says little about the struggle between Lipton and the province in 1909 to appoint a deaf school trustee for the district. ${ }^{4}$ This section

\footnotetext{
${ }^{4}$ Carbin, Deaf Heritage, 243.
} 
will use these sources, along with census records, to situate deaf parents and families demographically and geographically in the Prairies.

Establishing the existence of rural deaf communities in Alberta and Saskatchewan is challenging, for reasons beyond the lack of archival evidence. Deaf families lived among hearing people in rural settings, and deaf parents often had hearing children. Community formation, as John C. Walsh and Steven High argue, involves three processes: "interaction, imagination, and process." People within a community merge through living and acting together, imagining themselves as a community, and the construction of difference in ways unique to community members. In a rural Prairie setting, it seems clear that we can see "co-equality" as described by Joseph Murray - "a sense of permanent biculturality" - in the communities described in this section. Establishing distinct deaf communities in rural communities is more difficult, though as we will see, rural deaf people were connected to deaf Winnipeggers and other urban deaf in Western Canada and the United States.

MSD application records show that only eleven applicants had parents who selfidentified as "deaf." Of these, all had deaf siblings, meaning that only four sets of parents identified. Eight other applicants had parents who claimed that one parent was hard-ofhearing from illness or from war service. For the purposes of this chapter, we will define "deaf families" as those with at least one parent who is deaf, and at least one child. In the families identified here, however, both parents were deaf. An important part of this definition is the use of sign language, and in the identified families, there is evidence that

\footnotetext{
${ }^{5}$ John C. Walsh and Steven High, "Rethinking the Concept of Community," Histoire Sociale/Social History 32, no. 64 (1999): 272.
} 
all children arrived at the school with sign as their first language. These families were overwhelmingly farmers by occupation, though some had been printers who had gone into farming. While not all claimed an economic status, those who did wrote "indigent" at least once between multiple applications at different times.

The Arnolds moved from Iowa to Mayton, Alberta between 1900 and 1906. David Arnold, born in 1895, and Percy, born in 1900, applied for the MSD in October, 1906, and September 1907 respectively in forms filled out by their father. ${ }^{6}$ Mayton, a "ghost town" since the 1960s, is about twenty-five kilometers northeast of Olds, Alberta. A creamery, built in the early twentieth-century, served as the hamlet's economic engine, though the settlement was never larger than fifty residents. David and Percy's parents were graduates of the Iowa School for the Deaf in Council Bluffs, and seem to have had knowledge of, and connection to, deaf history as they gave Percy the middle name "Gallaudet." The family gave no indication of their "pecuniary condition" in the applications, but the MSD attendance book indicated that they only attended the school until 1909. It seems likely they returned to the United States, as MSD records also show that Percy later married a deaf woman in California and became a "successful chicken rancher." ${ }^{7}$

The Arnolds were part of a wave of Americans who moved to Alberta and Saskatchewan in the early twentieth-century. ${ }^{8}$ While there is no extant evidence that they knew other deaf people in the area, they would have represented the extension of American deaf networks northward, though by 1900 deaf movement and association was

\footnotetext{
6 “David Arnold,” \#192, "Percy Arnold,” \#202. Admission Applications, 1890-1939, PAM.

${ }^{7}$ Record of Pupils 1-374, 1889-1928. PAM

${ }^{8}$ Waiser, Saskatchewan, 29.
} 
well established in the Canadian/American western borderlands. Like many Americans who came north, and immigrants who had moved west, the Arnolds seem to have moved southward after a brief time in Canada. While the Canadian and American western borderlands represented the hardening of the political and military reach of two countries imposing settler rule in Indigenous space, these deaf connections remind us that connections and encounters along the border were not only national in character, as they were also local and community-specific. ${ }^{9}$ The Arnolds and others represent the number of deaf families and individuals who possessed, and made opportunity of, connections below and above the long border stretching from Western Ontario to the City of Vancouver.

The Haileys were a key deaf family in Lipton, a hamlet in south-eastern Saskatchewan. Adam Hailey had moved his family west from Manitoba in 1903, after marrying Christina, a recent graduate of the MSD. The couple had seven children, of whom five survived to attend the MSD, and the family operated a harness shop and farm in Lipton until Adam's death in $1934 .{ }^{10}$ He followed a wave of deaf settlers who had moved west to the Qu'Appelle Valley two years earlier from a group of homesteads in Manitoba. The settlers, centered around Gallaudet College graduate John Braithwaite, set up a series of farms in the Valley, creating a network of deaf labour for harvest season, when families would travel to harvest together as a community. ${ }^{11}$ This was a conscious deaf settlement scheme that was only partially successful - a fact lamented by the WCAD

\footnotetext{
${ }^{9}$ Randy Williams Widdis, "Crossing an Intellectual and Geographic Border: The Importance of Migration in Shaping the Canadian-American Borderlands at the Turn of the Twentieth Century," Social Science History 34, no. 4 (Winter 2010), 449.

${ }^{10}$ Carbin, Deaf Heritage, 239. "Hailey" is a pseudonym.

${ }^{11}$ Carbin, Deaf Heritage, 236.
} 
at the 1935 Convention as they sought to plan another deaf farming colony scheme that was ultimately rejected by both Alberta and Saskatchewan. ${ }^{12}$

The (Silent) Echo regularly reported on the Lipton and Cupar "settlers" in standalone sections of the paper. These reports usually occurred in the fall and traced the movement of individuals moving between farms to labour in the harvest around the Valley. By the 1920s, these reports included the movements of the adult children of the Haileys who were attending or had graduated from the MSD by the late 1920s. The MSD application records do not give us a complete picture of the deaf community in the Qu'Appelle area because only the Haileys had deaf children, with the children from other families becoming hearing adults with sign as their first language. ${ }^{13}$ The Haileys were, reportedly, "indigent," though the economic status reported by Saskatchewan applicants before the First World War likely over-report poverty, as the province required "affluent" and "easy" parents to contribute to the cost of tuition, unlike Manitoba and Alberta.

The number of CODA in the Lipton/Cupar area resulted in unique problems in local schooling. The hearing children of the Braithwaites and other deaf families attended school in a distant school division after the province turned down the formation of a local body in 1905. In 1909, a local board of hearing and deaf parents was formed again to appeal to the government to form Balrobie District No. 2353, which the province approved that year. Anson Van Luven, a deaf parent with hearing children, became the first deaf school trustee in Canada when elected by the community for the 1915-18

\footnotetext{
${ }^{12}$ Carbin, Deaf Heritage, 238.

${ }^{13}$ These children are usually referred to as CODA or "children of deaf adults."
} 
term. ${ }^{14}$ The reality of Lipton/Cupar in the early twentieth-century was a near-unique situation where a cluster of deaf settlers lived with several hearing families who could also sign. The Echo, in its report of the 1921 harvest written by an unnamed member of the community, does not distinguish between hearing and deaf individuals. "On the $30^{\text {th }}$ of October," a characteristic entry reads, "Mr. James Bain paid a visit to Mr. (A. Hailey) and had a good chat for awhile. He said he may come again and intends to take (A. Hailey) and family over to Mr. W. Krug's place for a visit sometime."15 A regular reader or community member would know that Mr. Bain, for instance, was hearing but was a long-standing member of the area's signing community, having come west with the 1903 wave of deaf "settlers."

The regular reports from Lipton make clear that this was a community of farmers that was geographically dispersed throughout the valley, but that the community as described by members in The Echo included deaf and hearing members. Given the paucity of sources, it is difficult to evaluate whether the situation fits Joseph Murray's model of "co-equality," but it seems from the Echo reports that there was a small, mostly co-equal community there until the 1930s. The Hailey's applications were filled out by community members who appear in the Echo reports but are not identified as hearing or deaf. Saskatchewan and Manitoba sources, which tend to follow deaf children's applications and educations, tell us little about hearing children in deaf-led families. Within The Echo and other deaf-produced sources, the phenomenon hardly merited discussion, as hearing children worked on family and community farms, learned sign

\footnotetext{
${ }^{14}$ Carbin, Deaf Heritage, 243.

${ }^{15}$ TE 30, no. 2 (November 15, 1921), 8, LLM.
} 
language and spoken English, and worked toward futures that were likely more openended than their deaf friends and siblings.

The application records only give one example of how hearing children within deaf families could smooth encounters with bureaucracy and the state. The Cole family, headed by a deaf couple who had moved to Alberta from the United States in the 1920s and were struggling to make farming work in the Duhamel area, put in an MSD application for their daughter Sarah in 1932. Sarah's two sisters were hearing, and presumably interpreted for their parents in their encounters with non-signing hearing people. The application, filled out by the Inspector of Schools in Camrose, states that it was based on information given by Sarah Cole's father "through his daughter - answered questions orally, replies written by D.M. Sullivan." ${ }^{\text {16 }}$ Sarah's application also states that "her sister taught her up to a year ago," meaning that she likely did not attend local public school.

The Rosthern area of Saskatchewan also had a cluster of deaf families. It is quite distant from Lipton, and sits north-east of Saskatoon, about halfway between that city and Prince Albert. The MSD paper featured several, but fewer, local reports from the Rosthern area. The Getz family were led by hearing parents, who sent their daughter Sophia to the MSD from 1906 to 1916 . The Getzes settled in the area between 1903 and 1905 with the Wiebes and the Lemkies, two families with deaf parents and hearing children, resulting in a situation where a small cluster of families lived in the area that principally signed but had a majority of hearing members. Sophia Getz's father served as an MPP in the Saskatchewan legislature during her childhood, but had lost his seat by the

\footnotetext{
16 “Sarah Cole,” 1932, no App \#. Admission Applications, 1890-1939, PAM.
} 
time the family moved to Rosthern. The Rosthern situation is sketchy, however, as there are few reports of the community in The Echo until 1921, when the paper reported that Sophia, “her younger sister and Mr. Ghomer Morris, the Uncle Sam’s boy, of Rosthern Sask, autoed over to Saskatoon to visit relatives and friends in the latter's 'tin lizzie.,"17 A small network of friends and relatives had seemingly coalesced around these three families, but with scant evidence, it is hard to make concerted claims about the nature of this small Rosthern community.

The Hoskins, of Tadmore, Saskatchewan, were a deaf farming family that sent three sons to the MSD between 1918 and 1933. George and Mabel Hoskins had moved to Saskatchewan from Minnesota in 1911 to set up a farm. George had been a printer in the United States before taking up farming in Canada. Their younger sons, Walter and Stephen, applied to the MSD in 1925 and attended for eleven years, after their eldest son, Carl, had died of illness at the school in 1919 (see Chapter Four). The Echo wrote about Carl's death in detail, in the same issue that covered Jacob Haus' accidental death. Carl, The Echo reported, had an operation for appendicitis at the Winnipeg General Hospital in February, 1919. He died at the hospital on March 3, with his mother by his side, after she made the long trip from Tadmore to Winnipeg for Carl's surgery. ${ }^{18}$ The first-year student's funeral was held in the city before his body was interred in Winnipeg. Mabel maintained a connection with the school, even before her other sons began to attend in the mid-1920s. The Echo reported that "Mrs. (Hoskins), mother of (Carl) who died so suddenly a couple of years ago during his first year at school, has renewed her subscription to The Echo. She wishes to be remembered to pupils and teachers and writes

\footnotetext{
${ }^{17}$ TE 30, no. 2 (November 15, 1921), 8, LLM.
}

${ }^{18} T E$ 26, no. 6 (February 15, 1919), 5, LLM. 
feelingly of her regard for the school." ${ }^{19}$ The Hoskins family suffered another loss when their son Stephen died between his application and admission in 1926, though the Student Attendance Book does not name a cause for his death in the summer of 1926 at the age of fifteen.

Carl's 1918 application, filed when he was eleven years old, allows us another peek into the experience of deaf children in local public schools. "(Carl) has been going to school this summer," his father wrote. "His teacher says that he can't speak any words plainly, but he can cipher and write good. She thinks it is best to send him to a deaf school. He can talk with sign language and fingers. ${ }^{20}$ Though Carl was reportedly only partially deaf, and became deaf at the age of four from scarlet fever, he, and his brother Walter, seem to have functioned fairly well in a public school setting. We can again see a local teacher working both within and outside of the established system to try to accommodate a local deaf child as much as possible, though it seems that Walter was more successful at his Tadmore school, as he attended for three years, rather than for merely a summer. Carl's father, being deaf himself, also reports more precisely what he means by when he outlines his son's language abilities - instead of vague stating that his son could communicate by signs, as did many hearing parents, George Hoskins reported that Carl could "talk with sign language and fingers," meaning that Carl's first language was likely ASL, not some kind of gestural home sign, as seems to have been the case with hearing parents.

\footnotetext{
${ }^{19} T E$ 30, no. 2 (November 15, 1921), 5, LLM.

20 “Carl Hoskins,” \#553, Admission Applications, 1890-1939, PAM.
} 
These deaf families, some of whom lived in signing deaf and hearing communities, were overwhelmingly rural, and were working to improve homesteads in the same way as any other settler family in Western Canada. These families, while surely subject to ignorance, apathy, and pity from some hearing neighbours and local officials key components of the humanitarian ethos theorized in the Introduction and described in Chapter Four of this study - saw themselves as settlers, involved in the larger "spadework" of colonialism. As we will see in the second half of this chapter, this commitment to colonialism was clearly stated in The Echo in commemorative pieces written about deaf "pioneers" and the few Indigenous students who attended.

Deaf families were also embroiled in a controversy over deaf marriage, a subject that was waning in intensity by the 1920 s, even as eugenics targeted toward other "dependent" or disabled groups intensified. A.G. Bell, in an 1883 address to mostly hearing educators of deaf students, argued that natural law meant that allowing deaf people to marry each other would result in "a deaf race." Bell's thinking is clearly eugenic, though his address was published in the same year that Francis Galton published his formative theories on what he termed "eugenics." ${ }^{21}$ Throughout the late nineteenthcentury, Superintendents of deaf schools kept, and published, detailed statistics on whether a child's parents were deaf or first cousins, in order to prove scientifically that deafness was not an identifiable result of deaf marriage or consanguity. Though Bell later walked back his arguments in favour of banning deaf marriage, the legacy of his address was felt well into the twentieth-century. The MSD kept record, when they could, of the marriages of their students to other deaf people after they had graduated, although it

\footnotetext{
${ }^{21}$ A.G. Bell, "Deaf Variety of the Human Race."
} 
seems that this was done for the purpose of following up on students and providing a record of the network of deaf alumni who were spreading all over the continent. The (Silent) Echo also extensively reported on deaf people marrying each other, or hearing teachers marrying deaf former students, as a way of tracking community and keeping MSD alumni up on social developments in the community. Several former students of the MSD married each other during the time under study, with some marrying deaf teachers there, as was the case of J.R. Cook and his wife, Annie. Others married deaf men and women from around North America, including Ontario, Nova Scotia, and California. As Melissa Malzkuhn argues, deaf marriage had remained, by the 1920s, a matter of community genealogy and connection, rather than the site of eugenic controversy that it had been twenty years earlier. ${ }^{22}$ Part of the reason for this was that the NAD and other deaf organizations in the United States consciously supported eugenic policies against disabled groups as a way of differentiating themselves from them. This study will argue this point in a different context in Chapter Six.

\subsection{Emerging Deaf Communities and (Silent) Echo, 1900-1920}

The MSD paper, as discussed in Chapter Four, connected students to their hearing families. It also served as a clearing house for ideas among the deaf communities springing up in the three Prairie provinces, a site for deaf to organize sporting and community events, as well as a space to foster and report on political mobilization. From 1892 until the later 1890s, Duncan McDermid and J.R. Cook co-edited the paper and penned its bi-weekly editorial section that commented on current disputes and events in

\footnotetext{
${ }^{22}$ Melissa Malzkuhn, "Compromising for Agency: The Role of the NAD During the American Eugenics Movement, 1880-1940," in In Our Own Hands: Essays in Deaf History 1780-1970, edited by Brian Greenwald and Joseph J. Murray, 171-192. (Washington, D.C.: Gallaudet University Press, 2016).
} 
deaf education or deaf people's lives. By the twentieth-century, Cook's name was alone on the editorial masthead until his death in the summer of 1918. This meant that the paper was deaf-edited during this time, and became an increasingly important voice in the development of the Winnipeg Association of the Deaf and the Western Canadian Association of the Deaf. This section will explore and evaluate the paper in this light. It will also examine the paper's community commemorations and explorations of important historical events in Western Canadian deaf history.

It is important to take a step back here to examine what I mean by "community" here. The issue of whether we can characterize groupings of deaf Canadians in the early twentieth centuries as "communities" is contested, though often from a twenty-first century definition of what the term means. By community, I am referring to something more practiced and concrete than the bonds suggested by Benedict Anderson's arguments about "imagined communities," though as we have seen, futurities are central to deaf community. ${ }^{23}$ I refer here to a grouping of individuals who share a linguistic bond as well as connections to the MSD and/or other schools and associations in the United States and Central Canada. ${ }^{24}$ Winnipeg had dedicated deaf clubs by the late nineteenth-century, hockey teams, and literary clubs before a turn toward a more explicit deaf politics by the 1920 s, as we will see in the sections ahead. The sinews that bound this community were The (Silent) Echo, the Winnipeg Association of the Deaf, and the Western Canadian Association of the Deaf, but also a myriad of social events and meetings that were too

\footnotetext{
${ }^{23}$ Benedict Anderson, Imagined Communities: Reflections on the Origins and Spread of Nationalism (New York: Verso, 1991). In the early twenty-first century, the term "community" has become permissibly applied to many groups who display less cohesion than these deaf communities did.

${ }^{24}$ David Quinto-Pozos, "Sign Languages in Contact," in Sociolinguistics and Deaf Communities, edited by Adam C. Schembri and Ceil Lucas, 29-60. (Cambridge, Cambridge University Press, 2015), 56.
} 
mundane to be commented on in available sources but key to the maintenance of community. This study will argue that deaf communities were present before a turn to politics in the wake of the First World War, and that although some deaf people remained outside of community, the fact that community members referred to them as "unorganized deaf" points to a centripetal force that was important, if not entirely irresistible. It will, in short, make a strong claim for speaking of "community" consciously and purposefully.

(Silent) Echo publicized and help organize deaf hockey teams in Winnipeg and around the West, both for working adults and students at the MSD. Hockey scores and news made up common and large sections in the paper, initially reporting on MSD games against local public schools and the Provincial Normal School, and eventually reporting on MSD players who had moved on to join other teams in adulthood. As Martin Atherton has argued in the British context, deaf community groups have gathered for generations for sporting and leisure events, and sports have formed an important role in deaf community formation. ${ }^{25}$ Jack Ulrich, an MSD graduate who became a professional hockey player, was extensively reported on in the second decade of the twentieth-century. Ulrich spent the 1912-13 and 1913-14 seasons playing for the Pacific Coast Hockey Association's Vancouver Millionaires and Victoria Senators/Aristocrats. Insisting publicly on the nickname "Silent Jack" rather than "Dummy Jack," Ulrich played professionally until 1916, when he retired and settled in Detroit. ${ }^{26}$ Referring to Ulrich proudly as "one of our old pupils," the Silent Echo reported that Ulrich had scored a

\footnotetext{
${ }^{25}$ Martin Atherton, Deafness, Community, and Culture in Britain: Leisure and Cohesion, 1945-1995. (Manchester: Manchester University Press, 2012), 6-7.

${ }^{26}$ Craig Bowlsby, Empire of Ice: The Rise and Fall of the PCHA, 1911-1926 (Vancouver: Knights of Winter Publishing, 2012).
} 
game-winning goal in a crucial game against Vancouver earlier that season, and that "for a lowly spare, Ulrich has risen to the plane of a hero in the eyes of the Victoria's hockey fans." ${ }^{27}$ Hockey was a constant concern of the paper from the late 1890 s until the end of the period covered by this study, with the Winnipeg Silents, a deaf hockey team that played semi-professional games in and outside of Winnipeg in the years before the First World War, soliciting players in its pages. ${ }^{28}$ The paper also celebrated the achievements of Walter Molinksy, an MSD and Silents alumnus who played on the Allan Cup-winning Regina Victorias, throughout $1914 .^{29}$

The central achievement of the deaf individuals coalescing around the MSD after 1890 was the formation of the WAD and, by 1923, the WCAD. Silent Echo carried a section called "City News" from the late 1890s until the end of 1914, when the paper began a "Winnipeg Association of the Deaf News" section. The Association, formerly called "The Winnipeg Silent Club," was mentioned for the first time under the WAD moniker in the December 1, 1914 issue in a report on the organization's first meeting. The group chose to have its inaugural meeting on Abbe L'Epee's birthday, November $24^{\text {th }}$, and discussed issues of local, national, and international importance. A resolution to assist the Ontario Association of the Deaf proposal to build a "Home for the Infirm and Aged Deaf of Canada" was passed, as was a resolution condemning Germany for using its deaf population to "dig trenches for its troops." 30 The Association also decided to change its name to align itself with the MSD, which had just dropped "dumb" from its

${ }^{27}$ SE 21, no. 7 (January 15, 1913), 4, LLM.

${ }^{28} S E$ 21, no. 6 (December 15, 1912), 6, LLM.

${ }^{29} S E$ 22, no. 13 (April 1, 1914), 4, LLM.

${ }^{30}$ The Echo 23, no. 2 (December 1, 1914), 4, LLM. 
title, and The Echo, which had just dropped "Silent" from its masthead. ${ }^{31}$ Most importantly, the WAD announced that it would focus less on sporting events and more on community events linked to employment, "the literary side," and engagement with other deaf associations in Canada and the United States. The Association, which planned to hold bi-monthly meetings, committed itself to serving "any deaf person residing in Winnipeg and vicinity who has interest in matters pertaining to the deaf." Beginning in February of 1915, the "WAD News" section was carried in every Echo issue.

Throughout the First World War, the WAD News offered a view into anxieties around deaf employment in the three Prairie provinces. Before the war, it reported that male MSD graduates were being hired by presses after 1912-13, but that this hiring slowed with the war and several deaf workers went to work as agricultural labourers. "Jacob Loewen," the WAD News reported on November 1, 1915, "after a long period of hunting for a job went to the wheat fields in Saskatchewan. He is back in the city and is doing messenger work for the United Tailors. He contemplates going to Southern Minnesota in the near future where he has a host of friends, some of whom he feels certain are willing to furnish him the oil to pour on his stormy sea." ${ }^{, 2}$ Un-andunderemployed young deaf men were reported in the WAD News throughout the war, though the printing industry reportedly had recovered by 1917 and employers were once again willing to hire deaf typesetters. The WAD gave no reasons for why the early war years had resulted in a decline in deaf printer hires.

\footnotetext{
${ }^{31}$ The phenomenon of dropping "dumb" and "silent" from mastheads and institutional names will be discussed in Chapter 7. There were two forces at work here - the rise of oralism, which suggested deaf pupils would no longer be silent, and the progressive movement's recognition that "dumb" and "Dummy" had become pejorative terms in the deaf community.

${ }^{32}$ TE 23, no. 3 (November 1, 1915), 5, LLM
} 
The WAD also held meetings about the war, hosted lectures about geo-political changes wrought by it, and commemorated hearing relatives of its members who were serving or had been killed or wounded in France and Belgium. J.R. Cook, the deaf printing instructor at the MSD, gave a series of lectures about the war and what he described as the "benefits" that would come from it in post-war life. ${ }^{33}$ Yet the war did not loom large in either The Echo or the WAD News section. More space was dedicated to masquerade balls, employment news, and marriage announcements. The Association funded its social and literary activities through the sale of manual alphabet cards and through dues paid by "Wads and Wadesses." The under-employment of some younger members likely made these sales necessary. One of those younger workers, printer's apprentice R.J.D. Williams, made and sold the cards on behalf of the WAD throughout 1915. "His time as an apprentice is up," the News wrote of Williams, "we hope, soon, to find him a full-fledged journeyman printer. ${ }^{״ 34}$ As we will see in Chapter Seven, Williams would spend the next ten years as the Supervisor of Boys at the MSD, before returning to printer work and concerted political activism in 1927. William's journey mirrors the WAD's. From 1914 to the early 1920s, the WAD published news of a social nature, focussing on community cohesion, support for individuals, and the "literary" development of members. This transformed, between the years 1919 and 1923, into a more overt focus on deaf political issues in Winnipeg and the West.

The war began to directly affect the MSD in 1918, when the school's vocational rooms at the University of Saskatchewan were converted into facilities for Invalided Soldiers Commission training in printing and other vocations. The Echo did not publish

\footnotetext{
${ }^{33}$ TE 23, no. 8 (March 1, 1915), 5, LLM.

${ }^{34} T E 23$, no. 11 (May 1, 1915), LLM.
} 
for the entire 1917-1918 school year. Upon its return in October 1918, the paper mourned the sudden passing of its editor and MSD printing instructor J.R. Cook. Cook had been a constant presence at The Echo and MSD for two decades. He had also been a rare deaf attendant of Deaf Education Conferences in the United States in the 1890s, when Duncan McDermid and he lectured against oralism to sometimes hostile audiences. ${ }^{35}$ An Echo piece commemorating Cook's life explained his importance as not only a printing instructor, but a mentor to the first generation of young printers educated at the MSD. "A number of the boys who received instruction in printing under him are journeyman today," read the piece, continuing that "he always won the respect of his pupils." ${ }^{36}$ The Echo noted that Cook had done much to push linotype instruction at the MSD, and that he was on the cusp of realizing that ambition. "Some few years ago...he attended the Inland Technical Printing School, Chicago, and obtained a certificate as operator and machinist, hoping some day to install a (linotype) composition machine ${ }^{37}$ in the school printing office. Mr. Cook ordered a new outfit for the school office and last June after school closed he had the equipment ready," yet that same June Cook would contract typhoid on a trip to Edmonton and pass away.

Commemoration, as represented in The Echo between 1912 and the early 1920s, was one of the key topics with which Cook and others in the deaf community wrangled with the issue of what it meant to be deaf in Winnipeg and Western Canada. Beginning in 1912, The (Silent) Echo began to print monthly excerpts from the first issues of the paper

\footnotetext{
${ }^{35}$ Barron, "The World is Wide Enough," 72.

${ }^{36}$ TE 26, no. 1 (October 15, 1918), 1, LLM.

${ }^{37}$ A linotype composition machine created type set one line at a time while an operator typed on a keyboard. It was the standard format for printing from the late nineteenth-century until the 1970s. Until 1917 , students learned on a manual type setting machine, and needed to be further trained as apprentices a situation that Cook had been arguing for a decade was holding back deaf employment in the industry.
} 
from 1892, calling the section "Twenty Years Ago." These sections featured moments in school history, like the return to the Portage location in 1892 after the fire, or the McDermid family's first trip to Lake of the Woods. ${ }^{38}$ While former students and deaf teachers were highlighted, the McDermids and hearing officials who supported the school in its first decade were more prominent here. Not only was the communal focus backward in time, but oriented toward hearing allies celebrated in the MSD's founding myth, much like the WAD's decision to meet first on L'Epee's birthday. The paper also printed group photos of past students, as well as hearing figures like Duncan McDermid and the Bannatyne family, who had furnished a temporary school in the family mansion after the 1891 fire. In 1914, the section featured an 1893 group photo of several elder male figures in Winnipeg's first MSD graduate generation, including Cook, Angus McIntosh, and others (see fig 5.1). McIntosh had been the first printing instructor at the MSD as an employee at the Manitoba Free Press, and other figures were early members of the Winnipeg Silent Club. Commemoration, when it did look to deaf Western Canadians, tended to look upon a small cadre of Winnipeg men who held positions within hearing institutions that allowed them a foothold in the liberal order. Women were completely absent from this wave of commemoration in The Silent Echo between 1912 and 1914. By 1921 The Echo could joke about this in its regular reports from the WAD, as when the paper reported that "There was a time when lady members of the W.A.D. were as scarce as hen's teeth. Today conditions have changed, the fair sex have an

\footnotetext{
${ }^{38}$ SE 21, no. 2 (October 15, 1912), 3, LLM.
} 
excellent chance of outnumbering the gentlemen in membership.."39 Leadership, however, would remain a different proposition.

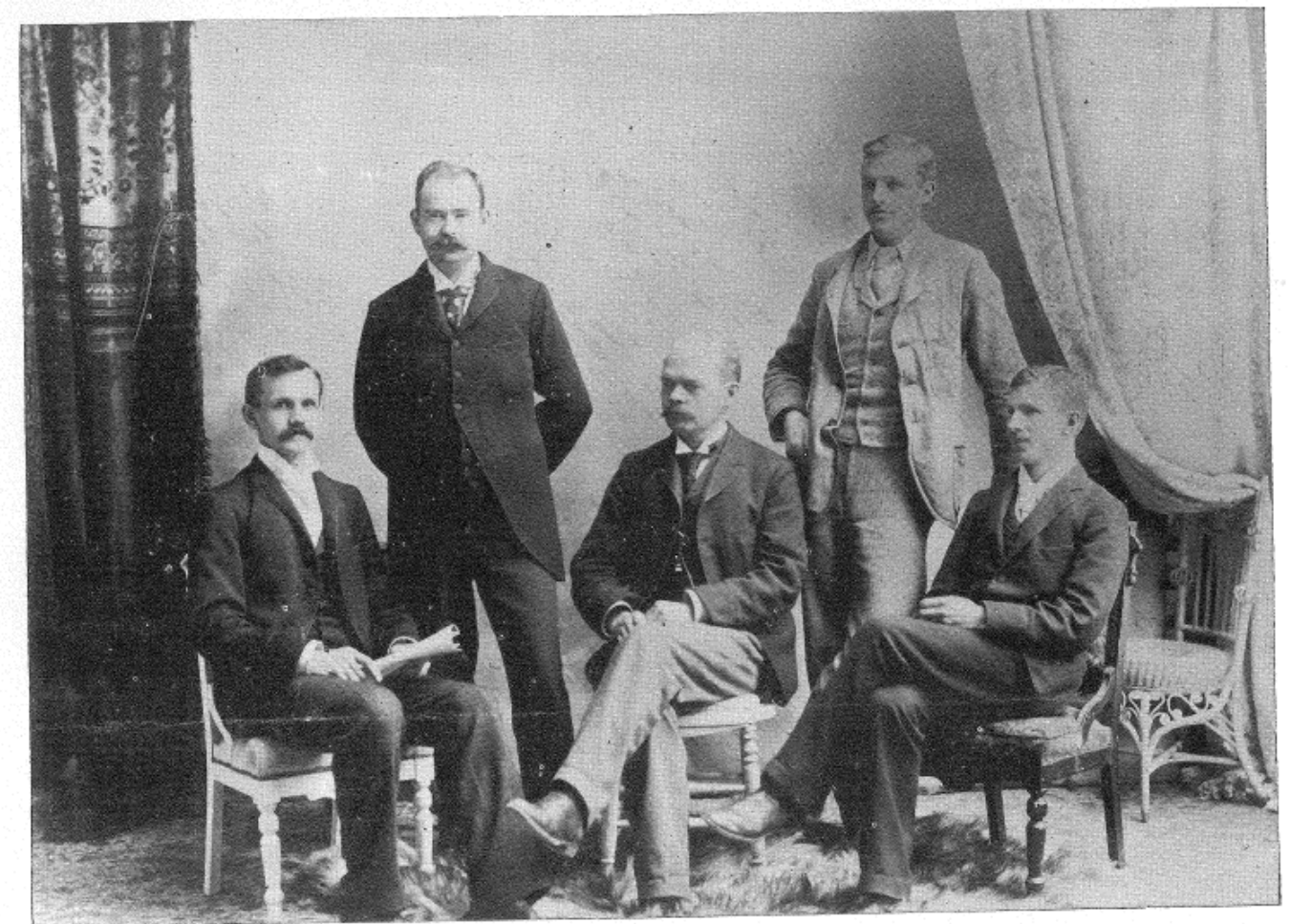

A FEW OF WINNIPEG'S DEAF RESIDEN'TS, 2 I YEARS AGO J. R. Cook Wm. Liddy

Figure 5.1 TE 22, no. 12 (March 16, 1914), 2.

The paper also commemorated the settler colonial myth in its own way - through the celebration of deaf settler John Parker, the farmer-teamster who had trained the Groom settlers in agricultural practices in 1884-5. Upon his death, The Echo published a revealing obituary that touched upon his financial success, his involvement with the Groom scheme, and the Brandon area's fascination with his status as a deaf teamster who accompanied the Canadian excursion to crush the North West Resistance in 1885.

Parker's obituary began with his birth in Scotland and his emigration to Canada "when

\footnotetext{
${ }^{39}$ TE 30, no. 2 (November 15, 1921), 9, LLM.
} 
still in knee pants." The piece then focusses on his military exploits, which included a stint as a teamster with a Canadian force opposing the Fenian Raids, and the 1885

Resistance. The piece, which quotes from a May 1885 edition of the Brandon Weekly Sun, read "John Parker, a deaf mute who is a capital shot, perhaps hit more Indians than anyone else in the field." ${ }^{40}$ After returning to his farm at Souris, he continued teamster and farm work for a few years, appearing in the Brandon papers several times as a local "deaf mute" who fascinated the community with stories. ${ }^{41}$ The piece dwelled on his invention of agricultural implements after he sold his farm and moved to Winnipeg, though he was bankrupted by bad investments and died at 78 in "the Old Folks Home in Middlechurch.” But the colonial mythology of the piece was strong. Parker's casket was draped in the Union Jack and his funeral was attended by local veteran's groups. Parker was celebrated here less as a deaf pioneer as an early settler who happened to be deaf, though the WAD helped organize the service. ${ }^{42}$

\subsection{The WCAD's Early Initiatives, 1920-1933}

The WCAD, announced in The Echo's December 15, 1920 edition as a regional expansion of the WAD, represented a shift in the priorities of what community members called the "organized deaf" of the region. MSD graduates had proliferated and moved back to Saskatchewan and Alberta, or gone on to attend Gallaudet College and became further exposed to deaf networks in the United States. The key figures in the WCAD's founding were David Peikoff, a young printer living in Saskatchewan and saving up for Gallaudet tuition, R.J.D. Williams, the Supervisor of Boys at the MSD, Charles White, a

\footnotetext{
${ }^{40}$ TE 29, 8 (November 15, 1921), 8, LLM.

${ }^{41}$ The papers make no mention of whether he signed or spoke, though other sources mention his lecturing deaf farmers in sign language in 1884 .

${ }^{42}$ TE 29, no. 8 (November 15, 1921), 8, LLM.
} 
B.C. deaf leader and MSD graduate, and Mary Lonsdale, one of the first graduates of the MSD who had a deep interest in her generation of deaf Western Canadians. Aside from Lonsdale, these founders were young and would become key deaf activists in Canada, especially Peikoff. As the membership of the group was dispersed around the region, the WCAD was divided into provincial sections that met monthly and communicated via mail and The Echo for the first two years before their inaugural 1923 Convention in Winnipeg. One month after announcing its existence, the WCAD had fifty-six members paid in full, and the first Convention featured 116 delegates from the four Western Canadian provinces. ${ }^{43}$

The WAD section had become more involved in political questions as the war ended, reflecting the sea change that would drive the early years of the WCAD. "An Act requiring interpreters at all hearings of deaf persons charged with insanity ought to be on the statute books of every province in the Dominion of Canada," the WAD section read in the October 15, 1919 issue of The Echo. "At present writing,

we know of two deaf men who are confined in provincial asylums for the insane. To all appearances and in conversations held in the sign-language of the deaf between these inmates and their deaf friends who have had occasion to visit them, the inmates are of rational and sound mind. To guard against the further practice of putting deaf persons in asylums, so charged by misguided persons and by those who have no understanding of the deaf, a campaign ought to be started by the friends of the deaf and the deaf themselves to see that any deaf person charged with insanity is given a thorough and fair examination. ${ }^{44}$

Minnesota, the WAD pointed out, had just passed a law that required interpreters at medical examinations that would determine whether a person could be committed against

${ }^{43} T E$ 28, no. 4 (January 15, 1921), 9, LLM; TE 31, no. 1 (October 15, 1923), 1-2, LLM.

${ }^{44}$ TE 27, no.1 (October 15, 1919), 4, LLM. 
their will. Deaf and hearing voices in the paper had rarely mentioned interpretation before 1919, save the incident with Mona Becker in 1894 and scattered humorous stories that lampooned the effect of oralism on interpretation. This framing of interpretation, as a necessary precursor to a level of communication that would meet a legal and medical standard, was new for the MSD publication. The piece likely shows the impact of transnational influence, as the NAD in the U.S. had helped launch the campaign that resulted in the Minnesota law, and, as we have seen, cross border deaf friendships and travel were evident.

The WAD seems not to have pursued the issue beyond this Echo piece, though without extant WAD correspondence, we can't be certain. We can see, however, that the WCAD followed the committal of at least two deaf people in a Saskatchewan mental hospital. WCAD correspondence saved by R.J.D. and Myrtle Williams shows that Williams intervened on behalf of Lizzie Potter, a deaf woman sent to the North Battleford Asylum by her father. A local doctor, who seems to have reached out to the WCAD, fought unsuccessfully to have her committal prevented. In a 1927 letter to the mayor of Perdue, Saskatchewan, Williams wrote that "you probably know that Dr. Johnson of your town has tried to save her from being sent to that place, declaring that she is not at all insane, and I am inclined to support Dr. Johnson."45 Potter's family, Williams argued, seems to have mistaken language deprivation for mental illness. "I understand that at home they did nothing but make a drudgery of her," he wrote. "It would seem that instead of encouraging her to read to improve her language, they preferred to try to make her a

\footnotetext{
${ }^{45}$ R.J.D. Williams to His Worship the Mayor, Perdue, Sask, copy, undated, 1. R.J.D. Williams Papers, Box 1 Correspondence, UAA. No application from a youth of that name exists in the Manitoba or Saskatchewan records.
} 
slave." ${ }^{46}$ Williams asked the mayor to provide an interpreter for Potter at the asylum so she could be evaluated fairly. His letter ended with a remarkable threat. "I would feel duty bound to ask the Association to prosecute her father if Miss Potter is sent to the asylum without a fair trial." ${ }^{, 47}$ Williams then wrote to Dr. Johnson, and stated that the Association would give him their "whole-hearted support" in the "fight you are putting up for her."48

J.W.MacNeil, the Medical Superintendent at Battleford, replied to Williams' letters about Potter and William Ellison, another deaf inmate at the asylum. Williams must have visited Potter in the interim between the two letters, as MacNeil stated that "this patient is just the same as when you were here, and there is no question but that she is a mental case. ${ }^{, 49}$ Ellison, the Superintendent argued, was committed because he was "threatening towards his sisters and brothers," and was "unwilling to perform any work, and became angry if requested to do so."50 Though he was "getting along quite well" at the asylum, MacNeil argued that "there is no question about his being a defective, and unless wisely handled, might be dangerous." Williams and the WCAD seem to have dropped both cases, likely because MacNeil had convinced him that both people had been correctly diagnosed. If Williams had pursued these cases, it seems that there would have been further correspondence in his papers.

The WAD/WCAD also took up the issue of fair representation for deaf defendants in criminal courts in May, 1922. An eighteen year-old Manitoba man, unnamed in the

\footnotetext{
${ }^{46}$ Williams to Mayor, 1-2.

${ }^{47}$ Williams to Mayor, 2.

${ }^{48}$ R.J.D. Williams to Dr. Johnson, copy, undated, 1. R.J.D. Williams Papers, Box 1 Correspondence, UAA. ${ }^{49}$ J.W. MacNeil to R.J.D. Williams, July 26, 1927, 1-2. R.J.D. Williams Papers, Box 1 Correspondence, UAA.

${ }^{50}$ Ibid, 1.
} 
paper, had been arrested in connection to the murder of his twelve year-old half-brother. He faced a trial at the assize sessions that summer, and was being held in a Winnipeg jail until the assize went through his town of Lac-du-Bonnett. ${ }^{51}$ The paper framed the story in terms of educational rights rather than interpretation because the defendant suffered from acute language deprivation - he could not speak, write, or sign, having never attended any school. "The provincial alienist in his report says the boy has the mentality of an eight-year-old child," wrote the paper, revealing that "the President of the Winnipeg Association of the Deaf has been making daily visits and has also been able to make some progress in attempts to teach him." "52 "His face is that of a young boy," reported the paper, "his whole behaviour has changed since the attempt was made to teach him." The piece argued that not only had the denial of an education denied him an important right, but also to any responsibility for his crime. "Possibly a year's training would be necessary before he could give any light on the crime he is accused of," the paper opined, after having partially blamed his family's status as "foreigners" for his lack of education. The crime that should be prosecuted, argued the piece, was "on the shoulders of those who robbed him of those ten years of enlightenment." ${ }^{, 53}$ In the "Pupil's Local" section of the same issue of The Echo, an unnamed student wrote that "He was never taught to read or write! It is a shame! Perhaps he would have been a fine man if educated." ${ }^{\circ 4}$

The WAD/WCAD seems not to have taken this issue further, aside from supporting the man from jail as much as they could before his trial that summer. Deaf defendants had long been accommodated within the adversarial trial system in British

${ }^{51} T E$ 29, no. 8 (May 15, 1922), 4, LLM.

${ }^{52}$ Ibid.

${ }^{53}$ Ten years being the time needed to complete education at the MSD.

${ }^{54}$ TE 29, no. 8 (May 15, 1922), 6, LLM. 
common law, though until the early nineteenth-century it was still possible for them to be found non compos mentis if they could prove that they were actually deaf and not faking. By this time, sign language interpretation was the standard for deaf defendants and witnesses in the British system. ${ }^{55}$ It is not explicitly stated in the Echo article, but the WAD president was likely teaching the man signs in order to prepare him for interpretation at his trial. Still, the piece casts doubt on whether there would be enough time. The article, then, criticizes his parents for letting him down, and is more subtle in its criticism of the Manitoba education system which had overlooked the man for a number of years. It also links deaf education and the notion of "good citizenry," especially in the pupil's comments. Taking pains to point out no other deaf person had been charged with a serious crime in the province, The Echo states that its graduates were "happy, prosperous, and law-abiding citizens." mentioned little in the way of criminal justice issues, seemingly hiding behind these twin shields of deaf education as an insurer of liberal individuality (and accountability), as well as Anglo chauvinism.

The first three major initiatives undertaken between 1923 and 1929 were indicative of the individuals that led them, though the WCAD membership voted on these as well. David Peikoff fought a B.C. ban on deaf drivers, Mary Lonsdale sought to redress the Manitoba government's failure to pay the MSD's first principal in 1890, and R.J.D. Williams worked to convince the Saskatchewan government to found a provincial deaf school. As we will see, this reflects Peikoff's strong-willed and forward-looking

\footnotetext{
${ }^{55}$ Christopher Stone and Bencie Woll, "Dumb O Jemmy and Others: Deaf People, Interpreters, and the London Courts in the Eighteenth and Nineteenth Centuries," Sign Language Studies 8, no. 3 (Spring 2008): 226-240.

${ }^{56}$ TE 29, no. 8 (May 15, 1922), 4, LLM.
} 
activism, Lonsdale's links to and interest in the MSD's past, and William's abilities as a messenger for the deaf community who could build and maintain alliances with hearing allies in a demanding political environment. Chapter Seven will represent an in-depth analysis of Williams' and the WCAD's efforts to work with the Saskatchewan government to found a School for the Deaf in Saskatoon. Importantly, these three initiatives represent the politics of the $\mathrm{WAD}$, which was primarily insulated within the pages of The Echo, transforming into those of the WCAD, which were more far-reaching and public in nature - through efforts to influence government decision-making, and change public perceptions through a new relationship with widely-read western Canadian print publications.

The 1932 WCAD Convention in Winnipeg saw these three figures present the results of their campaigns in detail, as well as a public disagreement between President Charles White and Superintendent Edwin Peterson of the new SSD over oralism. Despite Peterson's assertion in his report that he "didn't want to start a war here over lip-reading," his proposed compromises over oralism, in sight of a growing number of complaints from hearing parents, angered White, who responded that "Oralism is another matter we have to contend with. It has its place in the school curriculum for those who show an aptitude for it. What we dislike is to have a school that is entirely oral, that is, pupils are not allowed to use signs - they are supposed to lip-read all the time, at work and play."57 Either R.J.D. or Myrtle Williams has marked off this section in the family copy of the Convention Report. Edwin Peterson would leave his position in 1937, after which the

\footnotetext{
57 "President White's Response," Proceedings of the Fourth Triennial Convention of the Western Canadian Association of the Deaf, Marlborough Hotel, Winnipeg, June 28, 29, 30 and July 1,2.(Manitoba School for the Deaf, 1932). 89-71 R.J.D. Williams Papers, Box 2 Scrapbooks, UAA.
} 
SSD became increasingly oral, with signing becoming banned everywhere but the dormitories after a petition by hearing parents was delivered to the government in 1951 .

David Peikoff was one of the most impassioned and forward-thinking activists in the WCAD. Born into a Jewish family in Russia in 1898, Peikoff grew up with hearing parents. Deafened by disease at seven years old, he continued to speak Russian for a time. He entered the MSD in 1906. After attending Gallaudet University for his BA and Master's degrees, he returned to Canada in the early 1930s, taking a printing job in Vancouver. He began to report on a deaf driving ban in the province, and was nominated by the WCAD executive to push against the province's efforts. While Peikoff's report to the 1932 WCAD Convention in Winnipeg was one focal point of a number of controversies dealt with that year, his statement, and the failure of his campaign, caused a rift between Peikoff and other WCAD members that led him to resign the next year. Peikoff's casus belli for resigning, according to internal correspondence, was the renaming of the WCAD Gallaudet scholarship for Canadian students, but conflicts between Peikoff's vision and those of the other WCAD executives was rooted in the conflict over the B.C. driving ban. Peikoff began his report by telling the story of Robert Batho, a Vancouverite who, despite passing his driving exam, was denied a licence because he was deaf. Batho, Peikoff wrote, "packed his whole family in his unlicensed car in which he crossed the border unmolested and covered the entire distance of 3100 miles to Toronto, his destination, without any mishaps whatever. Eventually Mr. Batho qualified for a license to drive in Ontario.. ${ }^{, 58}$ B.C. authorities were embarrassed to be told of this protest by the WCAD, and initially formalized a deaf-driving ban that had been

\footnotetext{
${ }^{58}$ David Peikoff, "The Automobile Controversy in British Columbia," Proceedings, 39. Western Canadian Association of the Deaf Papers, 2000-87, UAA.
} 
only informally enforced by the Vancouver Police. It took another year of pressure on the Attorney General from Peikoff and the WCAD, as well as Edwin Peterson, to force the province to change its policy. Though Peikoff's 1932 report depicts the campaign as an unqualified success, Williams criticized Peikoff in private correspondence the next year for his mishandling of the situation, arguing that had Peikoff been less confrontational and not embarrassed the province through his publicity of the Batho incident, the ban would have been lifted much more quickly. In a 1933 letter informing Peikoff that Charles White would replace him in the B.C. leadership, Williams blamed Peikoff's "unwillingness to admit mistakes" for a growing unease with his methods among the WCAD executive. ${ }^{59}$

The next year, Peikoff tried to veto a WCAD resolution to change the name of the "McDermid Scholarship Fund" to the "WCAD Scholarship Fund," which had angered Superintendent Rodwell at the MSD and threatened donations from wealthy donors who had known Duncan and Howard McDermid. The scholarship was for Western Canadian students who had passed the Gallaudet College entrance exam and were planning to attend the deaf University in Washington. Peikoff resigned in response, stating in a letter to Williams that he felt the inexperienced WCAD should not have sole control over fundraising, and that the Duncan McDermid's deaf widow, Mary, should maintain influence. Peikoff also bemoaned the state of activism in the B.C. branch of the WCAD, saying that it had been difficult to bring "some semblance of order and instill some

\footnotetext{
${ }^{59}$ R.J.D. Williams to David Peikoff, February 5, 1933, 2. R.J.D. Williams Papers, $89-71$ Box 1 Correspondence, UAA.
} 
patriotism among the rebels." ${ }^{, 60}$ Peikoff argued that B.C. members saw the WCAD having a "partiality toward the prairie provinces," and that he did "not care now what opinions are flying in the air about my abandonment of the work in B.C." An angry WCAD executive, in an unsigned letter, complained that Peikoff "is just talking bull all the time and I'll be damned if I am going to be bamboozled by him." ${ }^{\text {61 }}$ Peikoff would move to Ontario and become a key activist in the Ontario Association of the Deaf, and would become - his continued correspondence with Williams shows - no less combative and "stubborn." ${ }^{62}$ As he wrote to Williams during the McDermid Fund controversy, he had "no yellow streak in my make-up."63

In contrast to Peikoff's more forceful form of political advocacy, Mary Lonsdale's campaign emerged from her research for a history of the MSD that she prepared for the 1932 Convention. In reaching out to ex-Principal Watson, who was alive, living in New Jersey, and ruined by the Depression, the Headingly resident learned that the government of Manitoba had failed to own up to the signed terms through which the province took over the school in 1888 . Lonsdale had been one of the first students at the MSD, her mother had been instrumental in the push for deaf education in Manitoba, and her brother Fred had been the first child to die while an MSD student, from scarlet fever he had contracted at the school. Mary had pitched the history project to the WCAD in

\footnotetext{
${ }^{60}$ David Peikoff to R.J.D. Williams, August 5, 1933. R.J.D. Williams Papers, 89-71 Box 2 Scrapbooks, UAA.

${ }^{61}$ Anonymous to R.J.D. Williams, April 30, 1933. 89-71 R.J.D. Williams Papers, Box 1 Correspondence, UAA. The writing matches that of B.C. WCAD executive George Riley, and there are several allusions to "Mrs. Riley's" opinions.

${ }^{62}$ The words are "Mrs. Riley's" from the above anonymous letter.

${ }^{63}$ David Peikoff to R.J.D. Williams, February 15, 1933. R.J.D. Williams Papers, Box 1 Correspondence, UAA.
} 
1931, to accompany a planned production of a school portrait of Watson, and the response had been warm from the executive.

In her historical report to the 1932 Convention, Lonsdale laid out the facts as Watson had relayed them. "Mr. Watson supplied all money necessary for expenses until the Government took over the school. He was paid no salary and spent between $\$ 1500$ and \$2000 and up to the present time Mr. Watson is still out that amount besides salary to that date." ${ }^{64}$ Williams organized a motion calling on the Manitoba Government to act, which was approved via correspondence with executive members. Lonsdale met with H.R. Hoey, the Manitoba Minister of Education, who agreed that Watson should be reimbursed in principle, but that the Depression made this impossible. Paying back Watson while teachers' salaries were being slashed province-wide would not be fair or politically possible, Hoey argued, in Lonsdale's retelling. ${ }^{65}$ Manitoba stood fast and did not reimburse Watson despite an agreement that Premier Greenway had concluded in 1888, but sent him a letter of appreciation instead.

Lonsdale's initiative seems less "political" than those of Peikoff, Williams, and others in the WCAD. While her work was geared to the benefit of a hearing Principal who had served the province for little over a year, Lonsdale explained that she saw it as not only a moral undertaking, but essential to restoring the story of an alliance between her parents, Watson, and several M.P.P.s who had pushed Greenway to found a provincial school. In 1933, she wrote a letter to Williams in order to outline the importance of the new contributions of her 1932 history to the standard narrative. Here

\footnotetext{
64 "Report of the History of the School," Mary Lonsdale, 1932. R.J.D. Williams Papers, Box 1 Correspondence, UAA.

${ }^{65}$ Mary Lonsdale to R.J.D. Williams, September 2, 1933, 2. R.J.D. Williams Papers, Box 1 Correspondence, UAA.
} 
Lonsdale reported Watson's accusations that M.P.P. Francis had received too much credit in the press for his role in founding the MSD, and that it had been Francis' electoral defeat in 1889 that had led to Watson's lack of reimbursement, given that it was Francis who had assured him of payment. Watson argued that the Lonsdale and Cameron families of Headingly, whose children were among the first MSD students in 1888, deserved credit above and beyond government officials. Lonsdale argued that the "Lonsdale, Cameron, and Flexon mothers who were delegated to wait on the gov't in connection with the School for the Deaf on more than one occasion but never mentioned in the press or pamphlet published at the school. They were delegates just the same and all working for one purpose. ${ }^{, 66}$ Her mother, Annie, had been instrumental in founding the school, and sent four children there.

Lonsdale was doing more than simply correcting the historical narrative, she was intervening in the school and deaf community history had that excluded women as formative forces. The WCAD did include women in its ranks and executive, but usually only as "Recording Secretary." Women were involved in decisions behind the scenes, as we can see in internal correspondence, but their achievements and ideas were often subsumed under their husband's.' Myrtle Williams, who created her husband's scrapbooks and saved WCAD material while writing notes in the margins, seems to have deferred to her husband's public persona when it came to recognition for the SSD achievement in 1931 (See Chapter Seven). Lonsdale's search for a narrative that met her recollections and included recognition of the work of hearing mothers in 1888 did so for personal and political reasons. Lonsdale's WCAD initiative, which seems simply

${ }^{66}$ Lonsdale to Williams, September 2, 1933, 3. 
backward-looking, was also about correcting the historical narrative of the Prairie deaf community to include women, though we cannot know for sure how Mary understood her actions. At fifty-three years old, she likely took stock to reflect on the actions of her mother, who had been in her late forties in 1888-89.

The WCAD, between 1923 and 1933, undertook a number of campaigns led by various regional executive members. The period featured some real successes - the founding of the MSD, the eventual defeat of a B.C. deaf driving ban, continued resistance to strict oralism in the Winnipeg and Saskatoon schools, and the creation of a concise and more representative regional community history. Charles White's frustration with Superintendent Peterson's wavering on oralism under pressure from Department of Education officials and hearing parents would portend difficulties for the community that would run from the mid-1930s until the senior class walkout at the SSD in 1973 - the elimination of deaf teaching at prairie schools save Williams himself, strict oralism, and the closure of the MSD in 1940 to house a Canadian Army officer school. As Jason Ellis has argued in the context of Ontario, the alliance between Department of Education officials and hearing parents was a powerful check on the ambitions of deaf associations, who spent much of the twentieth century being stymied on policy fronts. ${ }^{67}$ The generation of activists coming up in the late 10s and early 20s found themselves, by the 1960s and 70 s, unable to communicate effectively with even their allies - like Williams, giving a 1972 address to his former SSD colleagues through an interpreter, as none signed.

${ }^{67}$ Jason Ellis, A Class By Themselves?, 139. 


\subsection{Gallaudet College and Prairie Canada}

As the spirited fight between Peikoff and the rest of the WCAD shows, Gallaudet College and the WCAD fund that would allow Western Canadian students to attend were very important to deaf people in the region. It is difficult to quantify exactly how many Western Canadians attended, because while the MSD did record the names of those who passed the entrance exams and attended, it could not keep track of those who had attended before they moved to the region from Central Canada or the United States. Still, in the period under study, the MSD recorded that four students from Alberta and Saskatchewan attended Gallaudet: Rachel Stephenson from 1914-1915, as well as David Peikoff (who was from Manitoba but living in Saskatchewan before he went south), Peter Stewart, and Kathleen Stinson, who all attended Gallaudet in the 1920s.

The importance of Gallaudet to Peikoff is apparent everywhere in his story. He worked for years as a printer in Winnipeg and Saskatoon in order to save up tuition money, oversaw a regional, then national, fund for Canadian students to attend Gallaudet, was a fraternity President there in his senior year ('28-'29), and Editor-in-Chief for Gallaudet's student paper, The Buff and Blue. In return, Gallaudet named its alumni building Peikoff House in 1995 and bestowed him with an honorary doctorate. Upon the completion of his BA, he spent the summer of 1929 writing a history of deaf education for his Master's degree. The Saskatchewan Archives, as well as R.J.D. Williams' personal papers, feature more correspondence from Peikoff than anyone else in the WCAD, and much of this correspondence from his time at Gallaudet (1924-1929) was on his fraternity's letterhead and referred to the unique opportunity that being at Gallaudet offered him, both personally and as an activist still involved in Western Canadian issues. 
Peikoff, as we will see in Chapter Seven, solicited and compiled American institutional criticisms of Saskatchewan's 1928 deaf education legislation and sent them to Saskatchewan's Deputy Minister of Education, A.S. Ball, and the province's Premier and Minister of Education, James Gardiner. Provincial responses were warm, if not exactly prompt. Peikoff had already established an epistolary relationship with Gardiner, who the Gallaudet student knew was an ex-teacher and interested in educational reform. One of the central themes of his correspondence was convincing the province not to found a deaf school that also educated blind or intellectually disabled children. In August of 1928, Peikoff wrote Ball that "the recent Montana Association of the Deaf...deprecated the idea of the dual school of the deaf and feeble-minded children. This is but another instance of the widespread sentiment among the educators that the deaf should be educated independently of other types requiring government oversight." ${ }^{\text {.68 }}$ As we will see in Chapter Six, deaf education was often held up as a more worthwhile concern than the education of those with intellectual disabilities, which is why deaf and hearing educators worked so hard to keep "feeble-minded" children out of deaf schools. In the burgeoning eugenic era, deaf communities and their hearing allies stressed the "educability" of deaf children over those perceived to have intellectual disabilities, despite some MSD applicants who apparently bridged these categories. Peikoff, like other deaf leaders and their allies, fought for deaf education on their own terms, at times to the exclusion of and in contestation to the rights claims of other groups constructed as “dependent." In his personal campaign on behalf of the WCAD in 1928 and 1929, he succeeded. References to Gallaudet and his attendance there pepper these letters, as

\footnotetext{
${ }^{68}$ David Peikoff to A.S. Ball, letter, August 25, 1928. Department of Education Correspondence, 1922-29, PAS.
} 
Peikoff likely sought to use the prestige of being affiliated with an American college, even as a student, to his advantage with Gardiner.

Post-secondary education was important to the WCAD, and as we will see in Chapter Seven, the lack of a Canadian deaf college was one reason why the group wanted the SSD to be built near the University of Saskatchewan, so graduates could attend university classes without too much disruption. Gallaudet, however, remained central to elite deaf community networks throughout the continent. Two other MSD graduates to attend Gallaudet, Stinson and Stewart, became teachers at the Saskatchewan School for the Deaf upon its opening. Stephenson got married and raised a family, maintaining close ties with the SSD and Saskatoon's deaf community. In the early 1940s, all of the deaf teachers left the SSD under the pressure of growing oralism. Stewart was transferred to the Saskatchewan Correspondence School, and Stinson resigned in 1943. ${ }^{69}$

The transnational connections offered by membership in the "organized deaf" and attendance at Gallaudet were strictly closed to Indigenous students. Like Nepekwan, the son of a Blackfoot Chief who did not attend the MSD despite DIA's request discussed in Chapter Three, Blackfoot student Nap-ia-mo-kin did not attend the MSD. He was instructed in printing at the Regina (Indian Residential) School between 1896 and 1899, and received praise for his skills in the school's newspaper and annual reports. ${ }^{70}$ This study suggests, guardedly, that if he had been adopted by a settler family, he may have been granted admission to the MSD and been able to connect to the wider emerging deaf community in Western Canada. Nap-ia-mo-kin, though, was considered by the DIA and

${ }^{69}$ Carbin, Deaf Heritage, 165-166.

${ }^{70}$ Griffith, Words Have a Past, 38. 
Manitoba government to be Indigenous first, deaf second. It is invaluable to keep in mind that while the "organized deaf" were consolidating around a local and transnational conception of deaf community, this community rarely extended to deaf Indigenous children and adults. The creation story of deaf politics and organization on the Prairies is also one of outright exclusion, or at least fragmentation, along settler-Indigenous lines.

\subsection{Rights Rhetoric: Transnational Deaf Currents}

Calls for services or provisions that are due solely as a right of citizenship rest on received rhetorical and philosophical traditions. In the late 1860s in Ontario and 1888 in Manitoba, hearing parents convinced governments to build provincial schools based on tax-paying citizenship - that those parents of deaf children deserved to have their children educated, if they paid for the educations of hearing parents' children. Deaf petitioners in Manitoba in 1888 also appealed to state building arguments - that the province should take the responsibility for all of its citizens, and invest in the capacity to do so. The language of "Britishness" was in the background of these arguments - that Canadian provinces, as burgeoning outposts of Empire, needed to ensure settlers similar opportunities, services, and provisions as those on the British Isles and in other settler Dominions. The idea of services due solely from being a British subject, and civil liberties protected from state overreach, was a central pillar of the rhetoric of Canadian social policy from the high imperialist era until the Second World War.

Michel Ducharme argues that, in early nineteenth-century Upper and Lower Canada, these impulses supported one side of two contrasting notions of liberty "modern" liberty, based on adherence to and protection from British subjecthood under a 
dynamic Constitution, and republican liberty, a tradition in which individual freedoms are secured by a static constitution embodying a "people." The former was embodied by an emerging liberal consensus in the Canadas after 1840, and the latter influenced by the United States and French Republicanism while embodied by Papineau and Mackenzie's rebels in $1837-8 .{ }^{71}$ These contrasting visions of liberty - liberal vs. republican, were formed and transmitted in a trans-Atlantic context. Constitutional liberty was a compromise between emerging liberal and aristocratic ideals, with both Toryism and Canadian liberal traditions emerging from it - Toryism foregrounding social order, and liberalism foregrounding capacity through property ownership and based on a balance between choice and personal responsibility (what Fecteau has called "the pauper's freedom."). ${ }^{72}$

One would expect deaf activists in the early twentieth-century to make appeals based on British subjecthood, like similar activists did. Canadian blind organizations, by comparison, received a "shot in the arm" from returning blinded veterans after 1915, resulting in the formation of the CNIB that featured veteran's claims based on war service to the Empire. Blind Canadians who had been involved in struggles for blind education, lending libraries, and pensions chafed at the idea that their movement became identified with only those blinded in the war, and not the overall rights of British subjecthood, but the CNIB continued to highlight veteran's issues over those of other blind Canadians. ${ }^{73}$ Blind Canadians, in other words, tended to use rhetoric that

\footnotetext{
${ }^{71}$ Michel Ducharme, The Idea of Liberty in Canada During the Age of Atlantic Revolutions, 1776-1838, trans. Peter Feldstein (Montreal and Kingston: McGill-Queen's University Press, 2014).

${ }_{72}^{72}$ Fecteau, The Pauper's Freedom.

${ }^{73}$ Durflinger, Serge. Veterans With a Vision: Canada's War Blinded in Peace and War (Vancouver: UBC Press, 2010), 116.
} 
emphasized east-west connection through ties to Britain. Deaf activists, from the 1890s throughout the period understudy, presented their connections and intellectual traditions in a more complex way.

While deaf Canadians did use British iconography in their publications and celebrated links to the Crown upon the visits of different governors-general and lieutenants-general both before and after the war, they drew more profusely from republican notions of freedom with north-south links. These intellectual traditions were a mixed-bag of Anglo-American rhetoric that defy easy separation and definition. The reasons for this are similar to the reasons behind the common use of ASL over BSL in Canada. Deaf people in Canada had forged close links with Americans through migration and employment. More concretely, though, these north-south connections were a result of republication networks that crossed the Canadian/American border, in deaf school papers, deaf worker's publications, connections between deaf organizations through conferences, and shared subscription to the American Annals of the Deaf. Like the WAD writers who called for a Manitoba law that would mirror Minnesota's interpretation legislation, Canadian deaf had more concrete links to Americans, and also were more inspired by deaf movements in the United States who seemed to have more success than their British counterparts in the fight against oralism and deaf political rights.

Traced through (Silent) Echo from 1892 to the 1920s, we see a vague strain of republican ethos emerge, mostly embedded in American successes. In the 1890s, though, disagreement between American and Canadian educators was more common, as when a Texas deaf paper criticized the "McDermid Plan" shortly after his death. This plan to build one institution for "dependent" children in each province and to share responsibility 
between Manitoba, Saskatchewan, and Alberta, was criticized by the Texas Star as shortsighted, because of the "rate that Americans are pouring over the line into Saskatchewan, Alberta, and British Columbia and settling upon their rich virgin soil it will be but a few years when the demand for institutions nearer to home shall be insistently heard." ${ }^{, 74}$ Silent Echo reiterated that McDermid's plan had been to build institutions far beyond current demand and for this reason it was not short-sighted. Howard McDermid and J.R. Cook, and therefore the MSD, continued to support the one-institution-per-province plan for a few years, and deaf communities would not seriously begin to challenge it until the First World War, when Saskatchewan started a small, short-lived provincial school in Regina. Already, by 1912, J.R. Cook began to move on the issue, printed an editorial in support of a blind school in Manitoba, arguing that "there is no doubt of the necessity of such a school provided that there are a sufficient number of blind children of school age in the province," hardly a full throated response based on a right to education for all blind children. ${ }^{75}$

By the eve of the First World War, Silent Echo began to print numerous examples of American calls for expanded institutions, especially in the progressive northwestern states. We have already seen one example of this though the discussion of the Echo's reprinting of the North Carolina piece "The Deaf Child's Right" in its pages. ${ }^{76}$ That same year, The Echo printed a number of short pieces, mostly from American sources, that called for economic rights for families as a national project. "There never yet was and never will be a nation permanently great," argued the piece, "consisting for the great part

\footnotetext{
${ }^{74}$ Texas Star, quoted in Silent Echo 18, no. 5 (December 1, 1909), 4, LLM.

${ }^{75}$ SE 21, no. 3 (November 1, 1912), 4, LLM.

${ }^{76}$ TE 23, no.1 (November 16, 1914), 2, LLM.
} 
of wretched miserable families." ${ }^{, 77}$ While these pieces were not full-throatily republican, they represent a departure from the more conservative and "constitutional" tone struck in earlier Silent Echo debates over the need for educational expansion. Following and advocating imitation of American developments in teacher pensions and disability benefits $^{78}$, eliminating all tuition and costs to parents of deaf children, and forcing insurance companies to serve deaf clients ${ }^{79}$ were further campaigns imported from the United States.

The progressive era featured what seems like a revival of nineteenth-century concern that deafness could lead to children leading lives devoid of God, often signified through the metaphor of darkness and light. In the 1920s, writers in The Echo and WCAD arguments in The Grain Growers' Guide made similar arguments, but with the child's personal liberty being at stake, not the community's spiritual standing. This new rhetoric about language deprivation and education was linked to the importance of sign language to deaf communities, and the fears of the community that deafness would become associated with "feeblemindedness" in an era of increasing pressure from eugenicists on disabled people. A focus on personal liberty could cut between Ducharme's republican and modern (later to be "liberal") conceptions of freedom, and get to the heart of deaf arguments about how they wished to influence the state institutions that served and housed deaf children - avoiding language deprivation through

\footnotetext{
${ }^{77} T E$ 22, no. 14 (April 15, 1914), 5, LLM.

${ }^{78} T E$ 23, no. 12 (May 15, 1915), 4, LLM.

${ }^{79} T E$ 24, no 13 (April 15, 1916) 4, LLM.
} 
exposure to both sign language and English, because sign language was so central to deaf community. ${ }^{80}$

This rhetoric initially appeared in reprints from American deaf papers. By 1923, The Echo was regularly printing and reprinting short articles dealing with the problem of language deprivation in children, as well as a progressive era concern with early childhood development. "The whole world revolves around the child," an unattributed selection argued,

in the child's tiny fingers, head, and heart lie the weal and wore of the future. He is a bank developing in strength and power with the advancing years. What is drawn from that bank in the years that are to come depends upon what is deposited there while he is still a child. We cannot deposit carelessness, neglect, and indifference and expect in later years dividends of knowledge, integrity, and righteousness. ${ }^{81}$

This turn toward environmentalism was nominally at odds with the burgeoning eugenics of the 1920s. A neglect of child development and education for all children was a drawdown on a nation's bank account, to use the author's metaphor. It is also important that the piece is not explicitly about deaf children, as it frames the issue of education as a base necessity for all, and a necessary right for all children.

A month earlier, The Echo printed another unattributed article that dealt more explicitly with deafness, education, and the dangers of uneducated deaf children in the midst of powerful cultural and scientific fascination with eugenics. The piece is worth reproducing at length here, as it points out the Echo's concerns about access to education,

\footnotetext{
${ }^{80}$ Jarrett Henderson, "Lives, Liberties, and the Struggle for Self-Government," in "Macdonald Roundtable," Canadian Historical Review 94, no. 1 (March 2013): 103. Henderson, in the CHR discussion of Ducharme's book, helpfully suggests that Ducharme's ideas about liberty were perhaps broader than he considered, and link to self-government and "personal" as well as "political purpose."

${ }^{81}$ TE 30, no. 7 (March 15, 1923), 5, LLM.
} 
but also the concern with maintaining a firm border between deaf people and people with intellectual disabilities - an effort that we will examine in greater detail in Chapter Six. "Sometime ago," The Echo stated,

We had the privilege of examining two photographs of a six-year-old deaf girl. We would never know, until so told, that the pictures are of the same child. Picture one, is of a mouth breather, and the look in the eyes is apparently that of a feeble-minded child. Picture two, taken three and a half months later, is of a beautiful child, standing up with a graceful pose, her face showing unmistakeable signs of an intelligent little human being. Why the difference? This child was totally deaf, grossly neglected and ill treated by her guardians and naturally was very uncontrollable and had occasional fits of anger. A children's aid society had made application to have her placed in an asylum for the mentally defectives. In time a deaf couple appeared on the scene and suggested that the child might be deaf. They were given permission to take the child under their charge and observation...After three and a half months with her foster parents she had picked up enough of the sign language to make known her wants and carry on her childish conversation and is now attending a school for the deaf and is making a progress as any deaf child. We fear that there are, where the authorities are incompetent judges, some children in schools for the feeble-minded who should properly be attending a school for the deaf. ${ }^{82}$

As the borders between intellectually disabled, deaf, and "normal" children were realized and brought into being through practice in MSD admissions, they instantly became troubled. How, as in the above case, could officials "tell" if a child was deaf and "normal," or simply "feeble-minded?" What did "deaf and normal" mean? As we will see in Chapter Six, Dr. Howard McDermid strove to create these distinctions through the application process as soon as he took over as Superintendent for his father in 1909.

For the purposes of the current chapter, the above quote is a rich source for a discussion about the shift in deaf rhetoric from familial responsibility to protect the state to the state's responsibility to protect individual children from undiagnosed misery not of

${ }^{82}$ TE 30, no. 5 (February 15, 1923), 5, LLM. 
their own making. These efforts would, of course, also directly benefit civil society and the relief rolls. The child above benefitted not from state or BCP forbearance, but from the intervention of a deaf couple who were uniquely positioned to understand what was happening with the child. ${ }^{83}$ The child seemed doomed to an asylum based on her physical appearance, but this appearance was misleading and could be overcome by concern, care, and education. This, again, may be a swipe at eugenicists who attempted to scientifically categorize children with intellectual disabilities under the Binet scale, based on physical attributes and behaviour. The individual rights of deaf children, therefore, could only be assured through involvement of both bureaucracy and concerned deaf citizenry, whether "organized" or not. Though not a direct appeal to republican notions of liberty, deaf leaders were selecting aspects of two conceptions of liberty and making arguments in favour of a liberalism that had the republican elements of belonging, community, and self-governance. This was likely less of a conscious design of deaf leaders than the repurposing of common political and practical ideas circulating throughout the network of deaf papers, conferences, and migration around North America.

The issue of language deprivation was always at the forefront of discourse on deaf education, initially focussing on saving deaf children from spiritual ignorance, but moving toward deaf concerns about language deprivation by the early-twentieth-century. There is now a wide international scholarship on the effects of language deprivation and the importance of early signed language acquisition to the later mastery of written (or spoken) auditory languages, including recent studies by Jon Henner, Kristin Snoddon,

\footnotetext{
${ }^{83}$ See Chapter Seven for the simmering conflict between the BCP and the WCAD in the controversy over deaf education in Saskatchewan from 1927-31. The swipe at "a children's aid society" suggests that deaf groups long resented the power the BCP and CASs had over the lives of individual deaf children.
} 
Wyatt Hall, and others. ${ }^{84}$ These studies straddle the fields of linguistics and psychology, and now advocate against the idea of cochlear implants as a panacea for language deprivation, rather than purely against oralist policies or lack of access to education, as the early-twentieth century of deaf and hearing educators were. "Natural signed languages," Murray, Hall, and Snoddon argue, "have been shown to have the same neurocognitive benefits as natural spoken language while being fully accessible to deaf children." Waiting for deaf children to attend an oral school, or adapt to the use of a cochlear implant, risks the development of language deprivation, which is severe without "unhindered access to natural language" in a child's first five years. ${ }^{85}$ R.J.D. Williams, in his 1928 speech to the Women's Wing of the SGGA (see Chapter Seven) and hearing parent Gertrude Thompson in a 1930 letter to Williams (see Chapter Four), make similar claims with different concepts - Williams speaks of "a veritable prison" for uneducated deaf youth without the "key of language," and Thompson refers to "a child at the most plastic stage." ${ }^{86}$ The issue of language deprivation was easily and effectively forged into an argument in favour of the individual rights of children as well as the protection of the public from responsibility to support "dependant" citizens in a liberal order. This made it a consistent mode of framing the deaf education issue used by deaf activists like Williams and Peikoff in the 1920s.

\footnotetext{
${ }^{84}$ Joseph J. Murray, Wyatt C. Hall, and Kristin Snoddon, "Education and the Health of Children with Hearing Loss: The Necessity of Signed Languages" Bulletin of the World Health Organization 97, no. 10 (October 2019): 711-716; Jon Henner, Catherine L. Caldwell-Harris, Rama Novogrdsky, and Robert Hoffmeister, "American Sign Language Syntax and Analogical Reasoning Skills are Influenced by Early Acquisition and Age of Entry to Signing Schools for the Deaf," Frontiers in Psychology (2016), and many others.

${ }^{85}$ Murray, Hall, and Snoddon, "Education and Health," 711.

${ }^{86}$ The Western Producer, July 21, 1928. 15 School for the Deaf, 1922-1940, General Correspondence, PAS; Thompson to Williams, September 13, 1930, 2. R.J.D. Williams Papers, 1989-71 Box 1 Correspondence, UAA.
} 


\subsection{American Sign Language - Transnational Deaf Currents}

This is not to argue that the MSD and Western Canadian deaf community became an island of uninterrupted republican rhetoric in a liberal sea north of the forty-ninth parallel. Lines between Ducharme's dual conceptions of liberty had been eroding for decades, and indeed, republican notions of liberty had always been in Canada, though liberal and Tory ideas gained ascendancy after $1838 .{ }^{87}$ This study argues, however, that MSD rhetoric, after the 1890 s, fails to distinguish between these conceptions and printed neither appeals to rights as "British subjects" or as individuals within a body known as "the people." Transnational movement and links are important in this. The strength and tradition of these links are apparent in the spread of American Sign Language in Western Canada over British Sign Language - though writers at the time distinguished only between "one-handed" and "two-handed" alphabet.

As Supalla and Clark argue, before the success of oralism, signers and educators merely distinguished between "methodological" and "natural" signs - with the former being more common in schools and featuring signs delivered with the use of English grammar. After what they call the "Dark Period," ASL became academically recodified after years of surreptitious linguistic change. ${ }^{88}$ When scholars began to return their attention to the 1913 NAD film "The Preservation of the Sign Language," the differences

\footnotetext{
${ }^{87}$ Ducharme, The Idea of Liberty, 5.

${ }^{88}$ Ted Supalla and Patricia Clark, Sign Language Archaeology: Understanding the Historical Roots of American Sign Language (Washington, D.C.: Gallaudet University Press, 2015), 38-43. The recodification of ASL is usually dated to William Stokoe's 1965 ASL dictionary. William Stokoe, Sign Language Structure: An Outline of the Visual Communication Systems of the American Deaf (Buffalo: University of Buffalo, 1960); William Stokoe, Dorothy C. Casterline, and Carl G. Croneburg, A Dictionary of American Sign Languages on Linguistic Principles (Washington, D.C.: Gallaudet College Press, 1965). The "Dark Period" runs from the 1920s until the 1980s for these authors.
} 
between a "classic" and "colloquial" sign style was apparent. ${ }^{89}$ These distinctions make it difficult to identify the sign language being used in Canadian schools, though there are numerous references to "natural sign language" in (Silent) Echo. The only direct evidence of a collision between ASL and BSL in the sources consulted for this study is a complaint in the "Pupil's Section" of the Silent Echo about student resentment over having to learn the two-handed BSL manual alphabet in addition to the one-handed ASL one. ${ }^{90}$

Still, north-south deaf connections meant that American variations of sign language were planted and reinforced by deaf people migrating between Canada and the United States, fluid deaf educational systems that exchanged teachers and students, and Canadian involvement in national conferences. British deaf immigrants either had to bring knowledge of the one-handed manual alphabet with them or become proficient in American variations of sign language in order to participate in a Western Canadian deaf community that was resolutely north-south in orientation. The fact that nineteenth and early twentieth-century signers tended to fingerspell more often than modern ASL users likely made this a more manageable transition for users of British variations. This tendency was not due to preference, but to the common practice of forcing students to fingerspell rather than sign in many North American schools. ${ }^{91}$ This likely explains why the few references within (Silent) Echo on the collision of ASL and BSL were simply between the one-handed and two-handed alphabet.

The linguistic, community, and political links forged between American and Canadian deaf schools ensured that the Western Canadian deaf community were among

\footnotetext{
${ }^{89}$ Supalla and Clark, Sign Language Archaeology, 70.

${ }^{90}$ Silent Echo 2, no. 6 (November 15, 1893), 3, DHR.

${ }^{91}$ Supalla and Clark, Sign Language Archaeology, 98-99.
} 
the first to adopt a progressive ethos on the Canadian prairies, as these links brought American progressivism across the border. This includes both political and educational progressivism. Though Kerry Alcorn argues that progressive education was weak in Saskatchewan as late as the early 1930s, The Echo and WCAD correspondence shows that many in the deaf community were using progressive educational principles in their arguments against a "one size fits all" version of strict oralism, as their American friends

were to the south. ${ }^{92}$ Oralists were also using progressive rhetoric as well, as we will see in Chapter Seven, so it is important to, again, reiterate that these categorizations of ideas were as much bushes to pluck from as plant in the yard.

\subsection{Conclusion}

A deaf community was beginning to form on the Prairies in the 1890 s, but it was small, centered in Winnipeg and the MSD, reliant on the support of allies, and geared toward community fellowship more than politics. As oralists promoted the notion of separate deaf and hearing worlds, deaf Western Canadians increasingly turned toward liberal rhetoric and rights in order to shape the kind of communities they wished to live in. Rural deaf communities were consciously struck up through the homesteading movement, with some success, and sizeable numbers of deaf families lived near each other in Southeastern Saskatchewan, using the harvest as an opportunity to travel, work together, and socialize.

This community began to coalesce around some clear cut political ideas as the WAD began to expand into the WCAD in the early 1920s. A new generation of activists,

\footnotetext{
${ }^{92}$ Alcorn, Border Crossings. Progressive education will be defined and discussed fulsomely in Chapter Seven.
} 
graduates of the MSD and in some cases Gallaudet College, began to spearhead varied political initiatives to expand compulsory education in the west, allow deaf people to drive and have access to insurance, and continue to have access to combined education at the MSD and at a future SSD. Part of this movement was an assertion that deaf education was like other activities overseen by Departments of Education - a child's right that should be invested in for the good of both the child and the province. In short, deaf children should attend a school rather than an asylum. In contrast to hearing people who thought little of such distinctions unless they, in the words of hearing parent Mrs.

Stephens, were concerned "most vitally."93

What did this mean to deaf people and those hearing people charged with overseeing the admissions process at the MSD? As we will see, the construction of a "normal" deaf student was essential to protect deaf children and communities from the stigma of co-education with "feeble-minded" children. In contrast to the humanitarian attitudes about deaf education followed by most hearing people for much of the time under study, those with intellectual disabilities were, by the 1920 s, openly treated with fearful and forceful hands. Deaf people and deaf communities knew what this could mean, and, understandably, mostly carved out a spot for themselves outside of the most pernicious form of eugenics rather than fighting another battle. Eugenics was ascendant, and deaf people were already fighting so many battles.

\footnotetext{
${ }^{93}$ Mrs. Thomas Stephens to R.J.D. Williams, October 19, 1927. Box 1 Correspondence, R.D.D. Williams Papers, UAA.
} 


\section{Chapter 6: Constructing Intellectual Disability at the MSD, 1890-1920}

"Equality places men shoulder to shoulder, unconnected by any common tie. Tyranny erects barriers between them and keeps them separate. The former persuades them not to think of their fellows while the latter turns their indifference into a sort of public virtue."

Alexis de Tocqueville, $1840 .^{1}$

"This child is without a mind.

That one has a cave for a face

Blank, unlit, and fallen in.

Back wherever she began

Someone clapped his hands

And the fire went out.

But somehow, she continued to burn,

Curling like paper tossed into the flame:

Fingers, toes, and tongue drawn in

Limbs pulled toward the trunk as if

Wrapped tight in kitchen twine."

Molly McCully Brown, "Without a Mind,” $2017^{2}$

"The child, considered as a member of the human species, is incapable of social functions. He is restricted to physical individualism; he is not yet a full human being but rather a candidate for humanity."

R.B. Chadwick, $1911^{3}$

\subsection{Introduction}

Interprovincial jurisdiction created geographical parameters for the acceptance or rejection of the deaf children of Albertans and Saskatchewanians at the Manitoba School for the Deaf. With the 1897 achievement of responsible government in the Northwest Territories came an agreement between Manitoba and the Territories to accept the

\footnotetext{
${ }^{1}$ Alexis de Tocqueville, Democracy in America and Two Essays on America (London: Penguin Classics, 2003), 591.

${ }^{2}$ Molly McCully Brown, The Virginia State Colony for the Epileptic and Feebleminded: Poems (New York: Persea Books, 2017), 13.

${ }^{3}$ R.B. Chadwick, 1911 Biennial Report of the Superintendent of Neglected Children of the Province of Alberta (Edmonton: James Richards, 1911), 7.
} 
"Further West Deaf," and Principal Duncan McDermid quickly began to implement his own program of expanding deaf education beyond the borders of Manitoba. Earlier jurisdictional issues that had led to McDermid's advocacy for NW deaf students quickly declined in importance, and with the NWT (and subsequently Alberta and Saskatchewan) paying tuition for students further West, acceptance of students applying from across the Canadian West should have been relatively automatic.

This agreement led, however, to acceptance and rejection criteria along completely different lines. The boundaries imposed on the school's population ceased to be geographical and became a practice of constructing borders between "normal" and "feeble" mindedness. An analysis of all 233 application files from the geopolitical areas that are now Alberta and Saskatchewan show that Duncan McDermid, then his son Howard from 1909 to 1920 , actively sought to identify students who did not fit the ideal type of an educable deaf student. This chapter will argue that both Principals sought to identify students with the possible markers of intellectual disability, though Howard practiced his prerogative to reject applicants more often than his father, reflecting both his medical training and the growth of eugenic thought and practice in Western Canada during the First World War. Focussing on the McDermid period, 1890-1920, allows a detailed picture of admissions policy at a transformative time for the MSD during the rise of eugenic theory and practice in Western Canada. The construction and maintenance of an "ideal" deaf student at the MSD reorients the question of deaf citizenship and entitlement from the realm of political history towards the concerns of disability history, as an applicant's status as "disabled and deaf" often imperiled their admission to the 
school, and therefore barred them from an important state provision for students who were unable to thrive in public schools for reasons linked to disability.

The primary diagnostic tool used by Duncan and Howard McDermid to determine educability was the MSD's application forms. Under Duncan, these forms reflected an interest in both establishing basic intelligence and finding the place of applicants in what Superintendent Chadwick of the Alberta Bureau of Neglected Children called "the borderland of delinquency." ${ }^{4}$ The first was established through establishing a child's ability to follow and carry out tasks, construct basic forms, and control their bodily functions. The second was established through questioning a child's practice of tobacco use, masturbation, obedience, and "soundness of mind." A positive answer to any of these "trip-wire" questions could likely place an applicant's attendance into question. Ineducability, then, was constructed by the McDermids in similar but differently-focused ways. For children to be educable at the MIDD/MSD, they needed to be a) deaf or hardof-hearing, b) able to peacefully negotiate the residential setting with fellow students and teachers, and c) able to learn through speech or sign language. This chapter will deal with the McDermid's similarities and differences in evaluating each child's fitness for b), whether that meant morally, intellectually, or physically. While Duncan McDermid focussed only on the moral dimension, his son conflated b) and c) into an allencompassing category called "feeble-mindedness."

\footnotetext{
${ }^{4}$ R.B. Chadwick, Annual Report of the Superintendent of Neglected Children of the Province of Alberta. (Edmonton: James Richards, 1910), 11. Provincial Reading Room, Edmonton.

${ }^{5}$ See Appendices 1 and 2.

${ }^{6}$ I will use the term "feeble-minded" in direct quotes from primary sources, or when it is used as a meaningful historical category. Otherwise, I will use the term "intellectual disability." It is important to note that this does not mean that a child or behaviour referred to as intellectually disabled was so, but
} 
Duncan McDermid evaluated students on a deaf/hearing axis, usually only rejecting students as "not deaf." Howard would often see a hearing child who did not speak as an automatic marker for intellectual disability, and would reject a non-verbal, hearing student as "feeble-minded." He also collapsed physical and intellectual disability, seeking to keep both physically and intellectually disabled students from the MSD. I will argue that this was Howard's attempt to legitimize the MSD as a school and to distance it from the types of asylums also run by Public Works in Manitoba. Even after the 1914 movement of the MSD to the Department of Education, Howard McDermid increased his scrutiny of physically and intellectually disabled children. This chapter situates Howard's campaign to lift the MSD above stigma within two related historical trends - the rise of the medicalization of human diversity or disability, and the intensification and crystallization of institutional eugenics in Alberta and Saskatchewan. I separate the two types of students that Howard McDermid targeted most for rejection - into those "disabled and deaf" and those who were "hearing but nonverbal." The first could mean any discernible disability that a deaf child could have - physical disability, difficulty walking, bodily difference, or a perceived intellectual disability. "Hearing but non-verbal" meant a child who could hear but did not speak. Howard McDermid collapsed both of these types into the term "feebleminded," though he was immediately dismissive of the latter and more calculated in the application process of the former. These decisions spoke to a high level of authority and discretion delegated to the MSD from the Manitoba Department of Public Works, then (after 1914) the Department of Education. When Saskatchewan and Alberta legally codified what it meant by "defective" and "feeble disability" as described in this chapter is taken to be historically and socially constructed, not diagnostic. 
minded" in Child Protection legislation, they largely used the terms defined and practiced by Howard McDermid after his ascent as MSD Principal in 1909.

\subsection{Duncan McDermid and the Making of a Superintendent's Authority}

When Duncan McDermid took over the principalship of the MSD in September of 1890 , he found the limits of his own authority to be outdated and out of line with the institutional practices at other North American deaf schools. One of his first acts as Principal was to write a letter suggesting changes to the school's regulations that were being reviewed in the Executive Council in Winnipeg that fall. McDermid argued that the expectations and responsibilities placed in him by the government were not matched by his personal authority over the school's institutional life and curriculum. In a thirteen page letter to James Smart, Minister of Public Works, McDermid argued that he needed to have personal responsibility over the school's hiring, discipline, schedule, and admissions policy. "It is not my desire," he wrote,

to overstep the bounds as to the limit of my authority. I merely follow the example of all institutions of this character so far as the conditions will permit and do not ask for powers that are inconsistent with my responsibilities. If I am held responsible by the Government through the Minister of Public Works for the conduct of the officers and employees and the management of the Institution, these officers and employees should be under my immediate control otherwise I cannot competently carry out the orders and intentions of the Government as Principal of the school. ${ }^{7}$

McDermid argued that he, not the matron, should assume ultimate supervisory authority over female students, whereas existing regulations gave him authority over only male students. He also argued that he should be responsible for hiring employees at the school,

\footnotetext{
${ }^{7}$ Duncan McDermid to James Smart, undated (October 1890), letter. Public Works Correspondence Incoming, Provincial Archives of Manitoba. GR 0123 GR 1607, 8.
} 
not Public Works, in order to ensure that employees could communicate with students in sign language. Shortly after he wrote this letter, he had fired a Supervisor of Boys who had been unable to do his job "on account of his ignorance of the sign language." 8 Overall, McDermid sought the authority to ensure that he could hire the kind of employees that he felt the school needed, and that he could control the composition of the student body. His primary move here was likely against patronage hires, which he felt would be disastrous at the school, given its unique professional and pedagogical character. McDermid was also trying to maintain public conceptions of the school as an educational institution, as opposed to a purely ameliorative one that addressed the problem of uneducable and incurable children.

Though McDermid asked for, and received, changes in the regulations that allowed him to accept and reject students, he rarely rejected applicants. Application files show that while overcrowding problems between 1892 and 1893 caused a longer waiting period between acceptance and admission than former or subsequent periods, he did accept students whose parents gave affirmative answers to trip-wire questions in the forms. From 1890 to 1909 , he only rejected five out of fifty-seven applicants from Saskatchewan and Alberta. Of these five, two were rejected on the grounds that they were too old, and indeed they were 28 and 29 years old. A third was not accepted because his application stated that his family had a history of insanity, and that "his father became insane shortly after arriving in America." 9 There were, however, too few examples of

\footnotetext{
${ }^{8}$ Duncan McDermid to James Smart, letter. December 9, 1890, 4. Public Works Correspondence Incoming, PAM. GR 0123 GR 1607.

9 “William Albo,” App \# 218. Student Files - Admission Applications (Ab-Zm) 1890-1939. Provincial Archives of Manitoba, Winnipeg. E 0197A GR 4531 Box 1. McDermid did not, however, state his reasoning for rejecting Albo's application.
} 
disabled and deaf and deaf/non-verbal hearing applicants in this period to make firm conclusions on the parameters of Duncan McDermid's commitment to accepting every student he could. This commitment is, however, made apparent in other ways: especially in his acceptance of a man in his early thirties named Robert Fischer, who was referred to McDermid while he was in the city Immigration Sheds, for summer sign language and vocational training in $1894 .{ }^{10}$ The elder McDermid was clearly willing to be flexible in his acceptance procedures, even to the point of accepting student Samuel Reid, whose application stated that he was "not deaf." Reid was registered at the school from 18991903, so he clearly had accommodation needs that the MSD could meet, and was likely partially deaf. As we will see, Howard McDermid would very likely have rejected Reid outright.

\subsection{Eugenics and Hardening Constructions of "Feeble-Mindedness"}

Intellectual disability was not a new concept in late nineteenth-century Europe and North America. C.F. Goodey argues that modern understandings are located in seventeenth-century changes in judging capacity: philosophers and theologians began to separate the notion of "elective elevation" from a generalized divine grace. ${ }^{12}$ This meant that the capacity to achieve higher levels of grace were predicated on greater capacities of learning, which differed between individuals. Goodey argues that John Locke made similar capacity arguments about the capacity to judge politics, but dropped the notion of grace in his more secular argument. By the early nineteenth century, a "small, pathologically intellectually disabled population...(was) feared as the 'multitude once

\footnotetext{
10 "Robert Fischer," App \# 57. Admission Applications.

11 "Samuel Reid," App \# 92. Admission Applications.

${ }^{12}$ C.F. Goodey, A History of Intelligence and "Intellectual Disability": The Shaping of Psychology in Early Modern Europe. Farnham, UK: Ashgate, 2011, 96.
} 
was." $" 13$ Murray Simpson argues that two overlapping understandings of intellectual disability in the nineteenth-century made the direct construction of a student as feebleminded difficult and inconsistent. For most of the century, professionals distinguished between those who could learn and improve, or were educable, and those who could not. The principle difference lay in what Simpson calls either "a quantifiable distinction from the norm" or a qualitative variation. ${ }^{14}$ The first referred more concretely to "idiocy," or an unchangeable defect, while the second referred to "backwardness," or a deficit that could be made up through educational practice. These coexisted, and reflected a difficult grey area in social and educational response to intellectual disability. Jean-Etienne-Dominique Esquirol, an influential early nineteenth-century French doctor and practitioner, wrote in the Dictionnaire des sciences medicales that "To a certain extent one can improve the lot of imbeciles by accustoming them early on to some labour which can provide income for the poor imbecile or distraction for the rich one. But idiots only require attentive and intensive domestic care." 15

By the early twentieth century, the "idiocy" model was ascendant, and categories of feeble-mindedness were hardening in the medical profession to levels that ran from imbecile to moron, collapsing an earlier binary understanding of intellectual disability into a more complex singular model. Alfred Binet, who developed an influential system of intelligence testing in the early twentieth century, argued that "a scientific definition of

\footnotetext{
${ }^{13}$ Goodey, History of Intelligence, 97 . By "the multitude," Goodey is referring to elite fears of the public.

${ }^{14}$ Murray Simpson, "Othering Intellectual Disability: Two models of classification from the $19^{\text {th }}$ century." Theory and Psychology 22, no. 5 (2011), 541-555.

${ }^{15}$ Dictionnaire des sciences medicales, 1815. Quoted in Harlan Lane, The Wild Boy of Aveyron (Cambridge, Harvard University Press, 1976, 262-3.
} 
intelligence is impossible, and...this does not matter. It is whatever one likes. ${ }^{.16}$ Despite his recognition of the nebulousness of defining intellectual disability, Binet did contribute greatly to a near-universal codification of the features of "low intelligence" and intellectual disability. This hardening tainted all recipients of the feeble-minded label with an institutional and segregated response, regardless of where they may lay on the old scale between "backward" and "idiot." Though responses would differ, they would do so within the same institutional settings under the guise of ranked classes in the new institutions for intellectually disabled children. ${ }^{17}$

An association between physical disabilities and intellectual disability grew in the wake of the work of Francis Galton and early Anthropology, which centered intellectual disability in visually apparent characteristics of 'type,' much like growing notions of physical markers of criminality became more prominent in late Victorian society. ${ }^{18}$ The identification of "phenotypes" that denoted intellectual difference was difficult to trace as a coherent system, as it emerged in an "unstable realm of social consensus and anxiety," and that psychological phenotypes could never "be drawn with the quasi-logical precision of biology." ${ }^{\prime 19}$ Still, individual doctors began to associate certain behaviours and physical characteristics with intellectual disability, including physical disability, epilepsy or 'fits,' incontinence, non-verbality of hearing children, and other markers that would make the job of constructing intellectual disability easier over distance and through the medium of paper. Douglas Baynton argues that these visual characteristics were central to the

\footnotetext{
${ }^{16}$ Goodey, History of Intelligence, 7. The quote is Goodey paraphrasing Binet and other contemporary psychologists. Emphasis in original.

${ }^{17}$ Erika Dyck, Facing Eugenics, 69-70.

${ }^{18}$ Claudia Malacrida, A Special Hell: Institutional Life in Alberta's Eugenic Years (Toronto: University of Toronto Press, 2015), 24-26.

${ }^{19}$ Goodey, History of Intelligence, 217.
} 
training of American immigration officials by the early twentieth-century, and allowed agents to make snap decisions about the mental capacity and potential disabilities of immigrants arriving at Ellis Island in New York. ${ }^{20}$

Stacy Clifford Simplican argues that the roots of an exclusion of intellectually disabled people from citizenship has deep roots in early liberal thought. John Locke's writing about idiocy, and his "anxiety about political judgement," resulted in an understanding, in his Social Contract, of intellectually disabled people as outside of that contract - which was conditional on their ability to display the capacity to judge as reasonable political subjects. ${ }^{21}$ This, in turn, problematized the possibility of intellectually disabled people as liberal subjects. Howard McDermid adhered more to this line of thinking than his father did, and he ran the school at a time of rising intellectual frameworks that advocated improving populations through positive and negative eugenics. This was only possible with a late-nineteenth century turn toward a totalizing view of older models of idiocy under the purview of the concept of "feeble-mindedness," in which Simpson's two-tiered model of nineteenth-century intellectual disability began to melt into one.

The first national policy to reflect hardening attitudes toward disabled people and especially intellectually disabled people were the Dominion's immigration laws, which had transformed since the era of the Groom Expedition. Prohibited groups, by 1906, included intellectually disabled people, people with epilepsy, as well as blind, deaf, and

\footnotetext{
${ }^{20}$ Baynton, Defectives in the Land 122-124.
}

${ }^{21}$ Simplican, The Capacity Contract, 22. 
physically disabled immigrants. ${ }^{22}$ While these policies were buttressed by an economic rationale, they also rested upon hardening definitions of intellectually disabled people as “others" whose capacity for liberal subjecthood was suspect. Deaf Canadians were still largely defined as educable, but within a narrow, separate definition of deaf education that was heavily tied to vocational aims that intellectually disabled Canadians were often constructed as outside of.

Histories of intellectual disability in North America have overrepresented the prevalence of an institutional response, at least before the post-war period. Nic Clarke argues that, in the Canadian context, this has led to a situation in which only a small minority of students stand in for the experiences of all - which is difficult because intellectually disabled children at home led very different lives than those at the Orillia Institution in Ontario, the Home for Incurable Children in Manitoba, or the Provincial Training School in Alberta. ${ }^{23}$ The application files of children applying to the MSD who were constructed as intellectually disabled offer a small glimpse into the home lives of children at risk of being labelled "feeble-minded" at school or in community. I will not have space to fully address this evidence in individual files, but will focus in this chapter on the public school response to intellectual disability, and parental characterizations of their children's abilities and interests. Suffice to say, almost all parents of the thirty or so children rejected as "feeble minded" by the MSD describe their children as having the ability to work on the family farm "as much as anyone their age."

\footnotetext{
${ }^{22}$ Angus McLaren, Our Own Master Race: Eugenics in Canada, 1885-1945. (Toronto: Oxford: Oxford University Press, 1990): 56.

${ }^{23}$ Nic Clarke, "Opening Closed Doors and Breaching High Walls: Some Approaches for Studying Intellectual Disability in Canadian History. Histoire Sociale/Social History 39 (2006), 467-485.
} 
Manitoba founded a "Home for Incurable Children" in Portage la Prairie in 1890, as part of the same modest effort at institution building under Premier Thomas Greenway that produced the MSD. The Home initially accepted tubercular and intellectually disabled children as well as children labelled with mental illness, who were later sent to the Insane Asylum at Ninette. The Manitoba Government struggled to navigate the definitions of who was an "incurable child," and who was educable, into the early twentieth century. The Baldwin brothers, two blind children who were homeless in Winnipeg's streets in the 1890s and intermittently cared for by Winnipeg Police, drew the Public Works Department's attention in 1895 after a series of letters on their behalf from Winnipeg's Humane Society. The Society sought to have the boys sent to the Brantford School for the Blind in Ontario, but needed to advocate for the boys' soundness of mind and body in order to do so. One brother displayed tremors, but Society Secretary Gamble argued that he only did so because of physical harassment in the streets by other boys. "I saw him several times," Gamble wrote, "while he was in the St. Boniface Hospital and did not notice the slightest twitching of his muscles, I think it is only when the boys bother him on the street." ${ }^{24}$ As Manitoba lacked an agreement with Ontario at the time on blind student attendance at Brantford, the Baldwin brothers were sent to the Home for Incurable Children that year. This correspondence gives us a view of the limits of educability as constructed by Manitoba officials, but also the efforts of social reform groups to challenge these constructions.

The Home at Portage la Prairie, then, was a possible alternative for students who transgressed the lines of educability in Manitoba, which had recently expanded to include

\footnotetext{
${ }^{24}$ G.F. Gamble to Robert Watson, Minister of Public Works, letter, October 17, 1895. Public Works Ministerial Correspondence, GS 0123 GR 1687, PAM.
} 
deaf students. By the end of the first decade of the twentieth century, however, the MSD was increasingly confronted with applications from around Western Canada on behalf of students who experienced disability in multiple ways. Applications for students who were non-verbal, but only marginally deaf or hearing, began to increase in the five years before the First World War, as did those for deaf children who experienced physical disability in a myriad of ways. Howard McDermid took a two track approach once he became Principal in 1909 - advocating for improvements and expansion at Portage la Prairie and for similar institutions to be build in Alberta and Saskatchewan, while increasingly restricting the definition of which students could fit the parameters of education at the MSD. These ideal students were deaf but physically capable of vocational training, intellectually capable of acquiring oral or sign language skills in addition to literacy, and free from the taint of visual bodily disability that could increase the association of the school with institutions that did not attempt to educate children to become liberal subjects.

Political notions of liberal subjecthood and medical notions of bodily difference converged in eugenics, the study of the active maintenance of desirable bodily and intellectual traits through breeding selection. Eugenics rose from both horticultural and animal breeding practices that were later related to human beings by Francis Galton and A.G. Bell in 1883 in separate papers. Eugenics was, though, a scientific veneer for the practice of exiling or killing disabled babies, a practice that has little documentation but was clearly undertaken in the Middle Ages and Early Modern Europe. It is, to be blunt, scientific hatred and an intolerance for difference. For the purposes of this discussion, eugenics will be limited to the scientific and political form that arose on the Prairies with the Farmer's parties in the early 1920s, and consisted of active isolation through 
institutionalization of those diagnosed as intellectually disabled in Saskatchewan, and the active institutionalization and sterilization of intellectually disabled people in Alberta from the 1920s to the 1970s. By gatekeeping against deaf children he deemed as "feebleminded," Howard was placing them in the path of a life of institutionalization.

\subsection{Doctor Howard McDermid}

Howard was born while his father was a teacher at the Council Bluffs school in Iowa in 1885 . He was largely raised in the Principal's residence at the MSD, and was fluent in sign language from an early age. Howard and his sister Ruth forged friendships with students at the school, although they were educated in public school, then boarding schools. Howard, as early as 1894, helped organize and took part in public exhibitions of sign language for the hearing public for the benefit of social causes favoured by his father, especially for the establishment of kindergarten in Winnipeg. ${ }^{25}$ Editions of Silent Echo feature a great deal of material on Howard, through the lens of his father, J.R. Cook the printing instructor, or in student's letters about and to him while he was away at boarding school. While he was attending University and medical school at Manitoba College, he acted as an interpreter for deaf defendants and witnesses in the courts, along with his sister. He also interpreted for students when visiting ministers came to the school to deliver speeches and sermons. ${ }^{26}$

This childhood experience likely gave him an appreciation for the school's purpose and links to larger social reform movements that Howard and his father were dedicated to. When Duncan McDermid died of heart failure in 1909, Howard returned

\footnotetext{
${ }^{25}$ Silent Echo 3, no. 6 (October 15, 1894), 5.

${ }^{26}$ Carbin, Deaf Heritage, 142.
} 
from his new medical practice in Russell, Manitoba to become Principal. Within four years, he established a distinct oral stream at the school, from a single articulation class begun by his father in 1893 , and began to move the school toward the more fullydeveloped combined program that was common in North American combined schools to accommodate the rising political purchase of oralism in the early twentieth century. In his Annual Report of 1915-1916, Howard still maintained that combined education was practical and better than oralist options, but he reported beginning to prioritise early attempts at speech and lip-reading instruction for all students, though most students would simply revert to a manual stream after a short time. ${ }^{27} \mathrm{He}$ argued that intelligence was central to the successful acquisition of speech ability in deaf children, so, to him and many other principals of deaf schools at the time, maintaining an intelligent student body was seen as a way of ensuring success in the public eye in an increasingly oralist era.

Howard began to reject nearly all students whose guardians answered affirmatively to any trip-wire questions, and therefore betrayed any possibility of intellectual disability, bodily difference, physical disability, or blindness. Howard often grouped these under the term "feeble-minded," as he took factors like incontinence, "deformity," non-verbality, difficulty with walking, or lack of "soundness of mind" to be markers of intellectual disability. McDermid did not explain his thinking in marginal cases, like eleven-year-old Alf Larsen from Brick Hills, Saskatchewan, whose father wrote that he "walks like an old man." Larsen was almost totally deaf, and his application gave no indication that he should have been suspected as intellectually disabled, aside

\footnotetext{
${ }^{27}$ Howard McDermid, “Annual Report of the Manitoba School for the Deaf, 1915-1916.” Provincial Archives of Saskatchewan, W.M. Martin Fonds, Provincial Archives of Saskatchewan. S -M4 I 43, folder 4.
} 
from his difficulty in dressing himself. ${ }^{28}$ After a rejected 1916 application, Larsen was accepted on trial in 1919. After two days at the MSD, he was sent home, according to the student attendance logbook, as "f.m. (feeble-minded) Sask gov officer took him." 29

Howard remained principal of the MSD until a boating accident in the summer of 1920 ended his life. With his death, Gordon Lilley, a hearing employee of the school, took over as acting Principal for a few years. McDermid had preserved the school's combined program but had increased oral instruction and the "safeguarding" of the school's reputation from "feeble-minded" applicants who might have slipped into the system without vigilance. As Murray Simpson argues, the "discovery of the moron" in the early twentieth-century increased fear in some scientific, medical, and educational quarters of the possibility of undetectable "defectives" - which for McDermid was likely a threat to the school's reputation and educational achievement, rather than the threat to "racial health" that prominent eugenicists attributed to morons. ${ }^{30}$

\section{5 "Disabled and Deaf" and "Hearing and Non-Verbal" Applicants from Alberta and Saskatchewan}

Under the principalships of Duncan and Howard McDermid, thirty-seven out of 233 applications answered affirmatively to a trip-wire question, and thus fit our working definition of "disabled and deaf" and "hearing and non-verbal." Of these thirty-seven, thirty-three were rejected - with the other four being accepted on a trial basis. Three of the four "trial students" were rejected fairly quickly upon attending the school, meaning

\footnotetext{
28 "Alf Larsen," 472. Admission Applications.

${ }^{29}$ Record of Pupils 1-374, 1889-1928. Provincial Archives of Manitoba, A0061 GR 1635 Box 1, Book 2, 12 .

${ }^{30}$ Simpson, "Othering Intellectual Disability," 545. A "moron" was the most intelligent subset of the intellectually disabled categories in the Binet Test used by psychologists and educators in the early twentieth-century.
} 
that about $15 \%$ of applicants between 1890 and 1920 were rejected on the grounds of being "disabled and deaf" or "hearing but non-verbal," and the vast majority of those having been labelled as "f.m." by Howard. Furthermore, only five of these students were rejected by Duncan, and those due to their age (two), lack of deafness (two), and a history of familial insanity (one). This means that between 1909 and 1920, Howard rejected 32 of 176 applicants on these grounds, for a percentage of about $18 \%$. Many of these students tripped the wires that would have roused McDermid's attention to physical disability and bodily difference, but he always rejected these students, or accepted them on trial, under the concern of "feeble-mindedness," not the underlying issues that their parents or guardians identified.

Howard McDermid unified non-verbal but hearing and deaf and disabled students under the umbrella of "feeble-mindedness," which resulted in a construction of the term that was more expansive than simply one that can be categorized by the term "intellectual disability." Deaf students with physical disabilities or visual bodily difference were rejected as "f.m." by McDermid several times. The reasons for this may have as much to do with bureaucracy as medical expertise, because McDermid needed a simple, declarative reason for rejecting students. This caused alarm in Saskatchewan and Alberta and led those provinces to amend existing child protection legislation to actually define the terms "defective" and "feeble-minded."

Duncan McDermid had enshrined the Principal's near-carte blanche authority to accept or reject applications, for the reason that the Principal was ultimately responsible for the quality of life at the school. This discretionary power was coupled with disinterest from the Department of Public Works in Manitoba and the inability of Saskatchewan and 
Alberta to appeal McDermid's final decisions. Duncan and Howard relied on their educational and medical authority, respectively, to justify their decisions, and it seems that these decisions were never challenged by any of the three governments or the parents of children applying. Most deaf children were evaluated on paper and accepted outright, though at times with delays to allow space to free up at the MSD. Disabled and deaf or non-verbal and hearing children, whose guardians answered any troubling questions in the affirmative, were usually also rejected at the paper stage. Parents and guardians seemed to know or at least predict that these affirmative answers were potentially disqualifying, so they attached letters or wrote extensive notes about the abilities and interests of their children. They often did this while explaining an answer to a question that seemed disqualifying. Several parents who applied for children who had problems dressing themselves or identified problematic tempers took time to explain ways in which the child could succeed in tasks, or possible triggers for their anger. At times, these caveats did convince McDermid to allow an in-person meeting with the family, or, more likely due to the travel distances involved, a one-year "trial" acceptance. These accommodations - in-person meetings and trial acceptances - were rare and not representative of either McDermid's gatekeeping methods. Usually, the decision would be conveyed with a simple "accept," "accept - trial," or "rej - f.m." scrawled at the top of the application form. ${ }^{31}$

McDermid also introduced more medical authority into the application process than his father. He designed new application forms in 1915 that added a space for a doctor's signature, attesting to whether the applicant was "sound in mind" or not. Initially,

\footnotetext{
${ }^{31}$ Application Admissions, Provincial Archives of Manitoba.
} 
few parents attained these signatures, and attested themselves. By 1920, however, nearly three-quarters of applications featured this signature, and the ones that did not often explained this absence in the "notes" section. Parents in these cases often wrote that there were no doctors in the area or that their children had never been to a doctor. In introducing this change, McDermid was likely reflecting his own training and expertise, as well as a move toward a greater medical perspective in institutional bureaucracy during and after the First World War, identified by Burke, Dyck, Spagnuolo and others in their studies. $^{32}$

Superintendent Chadwick of the Alberta BNC was an early enthusiast of addressing "the problem of feeble-mindedness." From 1908 until his death in 1915, Chadwick composed an extensive section in his Annual Reports dealing with this “problem.” In his 1909 Report, Chadwick wrote,

Defective children represent the most serious child problem that is being faced at the present time in Alberta. Fortunately, the number is very small, there being aside from deaf, dumb, and blind children about twenty such children in the Province. The parents of these children are, as a rule, too poor and too ignorant to take care of them. Among the cases coming to the attention of this Department there are several cases of idiocy, two or three of cretinism, as well as other forms of mental and physical degeneracy, demanding the highest form of medical skill and expert knowledge. ${ }^{33}$

Chadwick's writing betrays a high confidence in his diagnosis of the problem that Alberta faced from "defective children," but confusion about how to diagnose individual children. Before the First World War, Chadwick collapsed physical and mental

\footnotetext{
${ }^{32}$ Burke, Building Resistance; Dyck, Facing Eugenics, and Natalie Spagnuolo, "Defining Dependency, Constructing Curability: The Deportation of 'Feeble-Minded' Patients from the Toronto Asylum, 19201925." Histoire Sociale/Social History 49 (May 2016), 125-154.

${ }^{33}$ R.B. Chadwick, 1908-09 Annual Report of the Alberta BNC, 11.
} 
disabilities and set them aside from sensory disabilities. He also focussed most of his reports on the few Alberta children sent to the Home for Incurable Children in Portage le Prairie in Manitoba. His superiors, at the Alberta Attorney General's Office, initially did not heed his ever-darkening calls for Alberta to act against an ominous future burdened with the "feeble-minded." As we have seen, it took sustained rejections of Alberta deaf youth by Howard McDermid for the province to begin to move toward its own response to the issue of intellectual disability - the construction of the Provincial Training School in 1923.

The Province of Saskatchewan began to take notice of the issue of intellectual disability under the Educational ministry of James Calder, who served from 1905 to 1912. On December $28^{\text {th }}$, 1911, Calder wrote to Manitoba Minister of Public Works Colin Campbell to make proposals regarding student transportation and the interprovincial agreement between the two provinces. He also reflected on the growing issue of applications for intellectually disabled children from Saskatchewan who had been barred from the MSD in the previous two years. He referenced the "McDermid plan," proposed by Duncan, that the Western provinces share the responsibility of institution for "all children who for one reason or another are dependent on the State for the opportunity to obtain such an education as would enable them to become self-supporting citizens."”34 This plan involved building separate institutions for deaf, blind, and "feeble-minded" children in different provinces, and sharing these institutions. Calder specifically referenced the problem of intellectual disability, writing that:

\footnotetext{
${ }^{34}$ James Calder to Colin Campbell, December 28, 1911, letter. Provincial Archives of Saskatchewan, James Calder Fonds, S -M2 GS 31 File 16 folder 3, 1.
} 
At the present time the work that is apparently the most ripe for action is that among "feeble-minded" children. We are receiving numerous applications from parents and teachers for assistance, and several children from this province have been refused admission to your Deaf \& Dumb Institution on the ground of feeblemindedness. I should be obliged if you would let me know whether you would be willing to grant an interview to our Superintendent of Neglected and Dependant Children, who in addition to this work under "The Children's Protection Act" has supervision over the Deaf \& Dumb children from Saskatchewan, who are in your institute, and also over the Blind children who are sent to Brantford. He had an interview lately with Dr. McDermid (Howard), who is, I think, as much impressed with the wisdom of some such notion as even his father. $^{35}$

While it is unclear whether a meeting happened between Campbell and Spencer Page, the Saskatchewan Supervisor of the Bureau of Neglected Children at the time, this letter helped to set off negotiations between the provinces to share institutions. The plan was not implemented, however, due to the unilateral doubling of government fees for nonManitoba student attendance at the MSD brought in by the new Manitoba Liberal government under Tobias C. Norris in 1915.

Calder was, while rhetorically and politically linking blind, deaf, and feebleminded children together under the term "dependent," drawing special attention to the gap in Saskatchewan's educational system that failed to address intellectual disability outside of the public school. Six-year-old Jane McKay's parents sent an application for her in 1911, accompanied with a letter from a travelling doctor who had examined her. Doctor Holton Williams described her as "healthy and of pleasant disposition but is somewhat backward," and prone to "explosive cries at intervals." 36 Williams argued that McKay would "benefit greatly from institutional training," but seemed unclear about what institutions were available to her, given that she was hearing but non-verbal. He

\footnotetext{
${ }^{35}$ Calder to Campbell, December 28, 1911, 2.

36 "Jane McKay," App \# 332. Admission Applications.
} 
ended his letter with a request that reflected his uncertainty - "If this case is unsuitable for admission, would you kindly advise the parents of a suitable school in Winnipeg or the East."

Local reform societies corresponded with McDermid about children that had been rejected from public school, especially those who were hearing and non-verbal. D.E. Ross wrote, in a letter attached to the application of Swift Current resident Jeffrey Wilson :

I beg to state that the matter is receiving the attention of patriotic societies here as well as some prominent and influential men. They seem to feel that the boy's education should be developed as far as possible by sending him to this school. The boy is fairly bright and could be taught a great deal, and he is dumb. It is impossible for him to go to the ordinary public school. ${ }^{37}$

Wilson's family was likely living in severe poverty, as his mother states in the application, due to the fact that it was a Swift Current relief officer who wrote an addendum to Ross's letter that claimed John was “quick to pick up things, especially anything musical." Despite the efforts of local societies to make his case to McDermid and F.J. Reynolds, the Saskatchewan Bureau of Neglected Children superintendent, John was rejected as feeble minded, as almost all non-verbal and hearing children were in the Howard McDermid era.

In contrast to Alberta Superintendent Chadwick's bombast, application forms reflect the concerns and confusion of parents, teachers, and doctors who sought educational opportunities for children who were not functioning well in public schools for a number of reasons, including intellectual disability, non-verbality, and others.

37 “Jeffrey Wilson,” App \# 527. Admission Applications. 
Anthony Weber's father, from rural Saskatchewan, went to the trouble to send in a paper application and visit Howard McDermid in his office in order to try to get him admitted to the school in 1911. Anthony was hearing and non-verbal. McDermid wrote on the paper application as an explanation for Weber's refusal, "Came again with father. Quite grown. Apparently simple, given to melancholia, wanders off and can't be found."38 McDermid's notes suggest that this was not the Weber's family's first visit, as he remarks that he is "quite grown." A number of parents from Alberta and Saskatchewan also added individual details and doctor's notes in support of the applications for their children when trip wire questions were answered affirmatively. Robert Davies' mother, in her application for her son, reported that:

This child understands all that is said around the house and is very cheerful about doing any work given him but does not seem to know the difference between right and wrong. Has a very bad temper - due a good bit to children on the street teasing him. The Doctor seems to think if he was in an institute where his mind would be busy on something all the time that he might improve a great deal. He is very fond of books and pictures and cries to go to school. But they don't care to have him at the public school. ${ }^{39}$

Davies' mother appealed to both her own understanding and her doctor's scientific authority to minimize her son's temper and diminished moral understanding. Still, Davies was rejected in 1914 as "feeble-minded." There were limits to the agency that parents, guardians, and doctors could exercise on behalf of child applicants.

Some children who could be categorized under deaf and disabled or "hearing but non-verbal" had parents or local officials draw up applications for them in the wake of family breakdown. Poverty, under the received category of "indigent" or applicantproduced categories like "destitute" or "hard-up," was reported in 228 of 321 applications

\footnotetext{
38 "Anthony Weber," App \# 335. Admission Applications

39 "Robert Davies," App \# 382. Admission Applications
} 
that answered this question between 1890 and 1931. Clearly, poverty was widespread in the areas from where application came on the Prairies during the McDermid period, although over-reporting of poverty might be an issue in Saskatchewan, where parents who were able to pay were responsible for fifty of the one hundred dollar tuition for the first twenty years of this sample. Still, there are many examples of family breakdown being the impetus behind a sudden application for a deaf and disabled, hearing and nonverbal, or an older deaf child who had not applied before. In many cases the death of a parent pushed a family on the economic brink over a threshold that forced the remaining parent or guardian to seek ways to disburse children to institutions, relatives, or paid labour.

Stephen Warner was a thirteen year-old hearing but non-verbal child whose father had recently died from pneumonia. His mother, in her application for Stephen, wrote that she had been working as a housekeeper, but "broken health compel me to break-up my home for the present. ${ }^{, 40}$ Stephen, in addition to being non-verbal, was reported by his mother to have a "slight irregularity in walking." This, in addition to his non-verbal but hearing status was more than enough for McDermid to reject him outright as "feebleminded." His mother reported no educational experience for Stephen, which reflects the experience of many non-verbal but hearing applicants with public school attendance. The reason for his application is likely closely tied to the break-up of the Warner household due to his mother's inability to work regularly. Like most of the deaf and disabled/hearing and non-verbal children rejected by Howard McDermid, it is impossible to determine where Stephen Warner ended up after his rejection at the MSD.

40 “Stephen Warner,” App \# 608. Admission Applications. 
The unwillingness of local public schools to accept deaf and disabled or hearing but non-verbal students was also a major driving force behind applications. A number of deaf children spent significant amounts of time in public school, from a year to a number of years, but ultimately they were referred to the MSD as a possible alternative at the behest of teachers or parents themselves. Of 233 children represented by applications between 1890 and 1920, 62 had attended public school in their local communities, and 26 had attended deaf schools in Britain, Eastern Canada, or the United States. A further six had attended public schools in their countries of origin, and seven had attended public school until they became deaf, then left. 81, however, reported no educational instruction whatsoever.

Children in the hearing but non-verbal category were less likely than their deaf counterparts to have attended public school. Between 1890 and 1920, only three of the twenty-nine such students had attended any amount of public school, and these three cases were on the margins of deaf and disabled identification as constructed by Howard McDermid, as well as on the margins of public schooling itself. One student, Madeline Autry, was non-verbal and hearing, and spent some time being educated at a convent. ${ }^{41}$ Another, Julie Agee, a deaf girl who had spent twelve years at the McKay School for the Deaf in Montreal, was described by her father in her application as "slightly backward."42 The third, Lotte Velden, spent eight days in public school before being sent home. Velden's 1917 application was rejected by McDermid on the grounds that she was

\footnotetext{
41 "Madeline Autry," App \# 241. Admission Applications. Autry was accepted in 1909, but discharged in early 1910 as "feeble-minded."

42“"Julie Agee,” App \# 429. Admission Applications. Agee was accepted by McDermid, but was discharged in 1917 as "feebleminded." Her father described her as twenty-three years old but that "she seems like a girl of 13 years."
} 
"feeble-minded." McDermid likely used specific wording given by her mother in the application to determine this, as Velden was deaf. Her mother wrote that after eight days at public school, she had been "sent home by school physician. Considered unmanageable. ${ }^{\$ 3}$

\subsection{Constructions of "Feeble-mindedness," Constructions of Ideal Deafness}

Licia Carlson argues that intellectual disability is too-often theorized as obvious in character, but is historically situated, and socially constructed, as much as other categories. ${ }^{44}$ Intellectual disability, or "feeble-mindedness," is therefore a contingent category. As the term emerged in the early period of eugenics and serious study of the "problem of feeblemindedness," there could be meaningful divergences between academic psychology/sociological writing and its construction in governance. In the three Prairie provinces, government officials began to take notice of the issue as it became a problem of compulsory education. As we will see, lower level officials confronted their superiors at the ministerial level for years before provinces codified what the term meant. The construction of what intellectual disability meant, and how the borderlands of cognition realized, was ultimately Howard McDermid's.

Application forms and the McDermid's characterizations of rejected students allow us to try to reclaim how Howard constructed intellectual disability in practice. It also allows us to see how the construction of intellectual disability shaped its opposite within a deaf educational context: the able, ideal, signing or speaking deaf student.

\footnotetext{
43 “Lotte Velden," App \# 501. Admission Applications.

${ }^{44}$ Licia Carlson, "Docile Bodies, Docile Minds: Foucauldian Reflections on Mental Retardation," in Foucault and the Government of Disability, ed. Shelley Tremain, 133- 152. (Ann Arbor: University of Michigan Press, 2005).
} 
Questions in the application forms seem designed to create a varied, almost biographical picture of the applicant and his or her family. Aside from questions related to family medical histories, causes and circumstances of the student's deafness, and the applicant's educational history, these forms featured several questions that seem designed to evaluate a potential student's fitness for the school's vocational programs. After the establishment of vocational programs at the school, the laundry and dress alteration program for girls and the printing and carpentry programs for boys were central components of how the school saw itself helping to forge futures for deaf students. These programs also produced printed products and school services in kind for the Manitoba government, essentially subsidizing the school's cost with student labour.

The ideal deaf student was initially either oral or signing. Over the tenure of Howard McDermid, the ideal shifted toward a deaf student who was either partially or late-deafened, potentially allowing for speech instruction. One of the reasons that oral students became more exemplary or ideal to Howard was that oral instruction was remarkably difficult and time-consuming, and especially so for early deafened students. "It is self-evident I believe," he wrote in his 1915-16 Annual Report draft sent to the Saskatchewan government,

that a child must be at least normally bright to learn the oral method, and to be educated by this method. The work is hard and painstaking for both the teacher and the child. The child must memorize the position of the lips, tongue, etc., for each consonant and vowel, and if they cannot, it is to my mind useless to persist, when a much easier and practical method should be employed to stimulate individual effort on the part of each child to reach out, and present the best, that is within him. ${ }^{45}$

\footnotetext{
${ }^{45}$ Howard McDermid, "1915-16 Annual Report," 8.
} 
As McDermid's argument here makes clear, the majority of students who proceeded with sign language instruction were capable enough to make use of the "most practical method," but had failed to prove themselves capable of oral instruction in the school's Class A. While Manitoba, over McDermid's tenure, did not institute a similar policy of other State and Provincial schools to neglect the education of "oral failures" for the benefit of oral successes, a practice of inserting "positive" trip wires to identify possible oral students seems to have been undertaken by Howard. ${ }^{46}$

Aside from the long-standing presence of questions establishing whether deaf students were acceptable for oral instruction, Howard added more direct questions about applicant intelligence by the end of his tenure. An example from 1924 shows that guardians were now asked to evaluate the potential physical weakness and 'mental condition' of their children in the final form designed by Howard McDermid. He added the following questions to the middle of the set of application questions given in Appendix 2:

17. Has the child perfect use of all its limbs?

18. Was the child a weak or strong baby?

19. Is there any irregularity in walking?

20. Or any difficulty in going up or down stairs?

21 . Is there any deformity or physical weakness?

22. What is the mental condition; bright, dull, or sluggish?

23. Will the child obey a command?

24. Can the child distinguish form and colors?

25 . Has the child any idea of number?

26. Has the child a retentive memory?

27. Has the child a constructive ability? ${ }^{47}$

\footnotetext{
${ }^{46}$ For an explanation of these kinds of policies in oralist schools, see Susan Burch, Signs of Resistance: American Deaf Cultural History, 1900 to World War II (New York: NYU Press, 2002).

${ }^{47}$ Alun Roberts, 1924. Admission Applications.
} 
These questions, many of which remained in application file examples until the school's first closure in 1940, drove at establishing a case picture of students' cognitive and physical abilities to give the Superintendent a more complex picture from which to establish potential intellectual disability. Most deaf applicants with physical disabilities continued to be rejected as "f.m." throughout the 1920s, under subsequent Superintendents, and non-verbal and hearing students were rejected on the same grounds, although the number of applications for the latter category fell after the establishment of the Alberta Training School in 1923.

Howard McDermid contributed to a construction of three "types" of deaf student: oral students who could be trained to "pass" as hearing, manual and written students who could not pass but could use written communication in a potential workplace, and those who could not be expected to do either, in the estimation of Superintendents. These types seemed linked to an expectation of future liberal subjecthood - self-reliant and employed and able to contribute to the Western Canadian polity in an informed and responsible way. While the barring of deaf and disabled and non-verbal/hearing students presented a solution to a potential public relations and accommodation problem at the school itself, it presented problems for the goal of mass education that provincial governments began to take seriously in the early twentieth-century. In an age of compulsory education, where did "feeble-minded" students fit in politically and educationally?

\subsection{Compulsory Schooling on the Prairies and Departments of Child Protection}

Saskatchewan and Alberta passed Child Protection Acts in 1908 and 1909, respectively. These Acts were modelled on Ontario's, and were originally Acts that simply set up a process for the incorporation of local Children's Aid Societies and named 
vague protections. The Acts were created in response to the calls for regulations around child welfare from social reform movements, and as a response to local difficulties with establishing effective anti-poverty regulations in a territorial setting. ${ }^{48}$ These older regulations put the burden of a response to familial and child poverty with local communities, but this stretched the resources of some small rural communities.

The Saskatchewan Children's Protection Act created the position of Superintendent of Neglected Children, which was designed to oversee the initially limited reach of the Act - to incorporate and monitor Children's Aid Societies and oversee foster and adoption proceedings from a distance. The Superintendent was shortly also made responsible for all deaf children who were transported by the province to Winnipeg. The 1908 Child Protection Act did not, however, originally specify any response along the lines of disability, deafness, or intellectual disability. It did contain, as did Alberta's 1909 Act, the seeds of future difficulty in vague assertions toward a compulsory schooling law that did not yet exist. The Saskatchewan CPA simply stated that "Any officer, peace officer, constable or policeman may apprehend without warrant and bring before a judge as neglected any child who is...suffered to grow up without salutary parental control and education. ${ }^{, 49}$ Letters calling for a compulsory law flowed into the office of Education Ministers in Regina, especially during James Calder's tenure (1905-1912). In October of 1908, Calder received a letter from a citizen named Frank Arnas from Qu'Appelle, who argued that "the new Act for the Protection of Neglected Children covers habitual truants, but I find from information from the Deputy Attorney General that it cannot go into force

\footnotetext{
${ }^{48}$ Tamara Gene Myers, Youth Squad: Policing Children in the Twentieth Century (Montreal and Kingston: McGill-Queen's University Press, 2019), 82-85.

${ }^{49}$ Saskatchewan Children's Protection Act. 1908 c.31, s.10;1908-9; c.15, s.s.4(3)
} 
until a Children's Friendly Society is established. In the meantime what are we to do."50 As Arnas states, elements of a compulsory schooling law was on the books, but there were no penalties to enforce these laws, aside from the removal of children whose parents kept them from school. B.W. Greenfield of Bulyea, Saskatchewan wrote Calder the following year to suggest ways around burdensome local taxes in homestead areas where there were few school age children, in order to finance more expensive town and urban systems. Greenfield argued that under existing law, children had to show up and sign a ledger, but not necessarily attend ever again, so government funds could not be obtained because districts did not have a high enough average attendance to receive the full provincial grant. Local taxes were simply repurposed into more populated systems. After making an argument about how the solution was an ironclad compulsory school law, he ended his letter with the assertion that "something should be done in the interests of the children and also the taxpayer." ${ }^{, 51}$ Clearly, the push for effective and fair compulsory schooling laws came from both child-saving and tax relief impulses among sections of the public.

Alberta passed a comprehensive compulsory school law in 1910, while Saskatchewan, mired in the political implications of block settlement resistance to the policy, passed similar laws in $1917 .^{52}$ These laws helped to clarify some of the difficulties and uncertainties that plagued the older laws, but they created new blind spots that

\footnotetext{
${ }^{50}$ Frank Arnas to James Calder, Minister of Education, Saskatchewan. Letter, October 6, 1908. James Calder Fonds, Provincial Archives of Saskatchewan, S-M2 GS 31 File 16 folder 1. Arnas is referencing Children's Aids Societies when he writes "Children's Friendly Society."

${ }^{51}$ B.W. Greenfield to James Calder, Minister of Education, Saskatchewan. Letter, September 26, 1909. James Calder Fonds, Provincial Archives of Saskatechewan. S-M2 GS 31 File 16 folder 1, page 2.

52 Roome, Patricia. "Alexander C. Rutherford." In Alberta's Premiers of the Twentieth Century, ed. Bradford J. Rennie. Regina, University of Regina Press, 2004, 9; Ted Regehr. "William M. Martin.” In Saskatchewan Premiers of the Twentieth Century, ed. Gordon L. Barnhart. Regina, University of Regina Press, 2004, 52.
} 
became a political issue - education for those who could not, or were not allowed to, go to public schools. While deaf students, and to a certain extent blind students, were sent out of province in a systematic and predictable manner, "feeble-minded" children presented a problem for this system. In order to be excluded from the public school system without new responsibilities being created for the provinces, working definitions of "feeble-minded" needed to be established.

Alberta, under a new United Farmers of Alberta government in 1923, would build the Alberta Training School outside of Red Deer, in order to house children labelled with intellectual disabilities. Legislation that created the institution did codify the meaning of "feeble-minded" along Binet's lines - a ranked system from idiot to moron - where expectations and tasks would differ but conditions would not. As Claudia Malacrida points out, calling this institution a "school" is a willful act of deception, if a necessary one in a liberal order. Students there were trained in few skills, let alone employable ones, especially in the Lower Order classes. ${ }^{53}$ Legislation enacted by the province's Social Credit government in the 1930s stripped rights of individuals with an IQ score below 75, allowing for their sterilization without patient or parental consent. This continued in force until the early 1970s.

Saskatchewan began to grapple with the issue of intellectual disability with a factfinding trip by the province's Superintendent of Neglected Children, Spencer Page, in June of 1912. Page travelled to see the "establishments for training and control of feebleminded persons in both the States of Wisconsin and Minnesota," and reported to the government that Saskatchewan needed to increase its rate of institutionalized

\footnotetext{
${ }^{53}$ Malacrida. A Special Hell.
} 
intellectually disabled. Page reported that only four of forty-four intellectually disabled children were housed at the Home for Incurable Children at Portage le Prairie, Manitoba.${ }^{54}$ Page submitted the same text for the next six years in his report, signifying that the province did not attend to the issue until after his death in 1918. Saskatchewan's response to the growing problem identified by Calder in 1911 was therefore earlier than Alberta's, aided by the possibility of sending children deemed feeble-minded to Portage Le Prairie, Manitoba, and then Red Deer, Alberta. Saskatchewan did finally codify what was meant by "feeble minded" in a 1927 amendment to the Child Welfare Act, which also allowed for the confinement of intellectually disabled children without parental consent, but not their sterilization. ${ }^{55}$ "Defective child," the Act states,

Includes:

(a) an idiot child, that is to say a child so defective in mind from birth or from an early age as to be unable to guard himself from common physical dangers;

(b) an imbecile child, that is to say a child in whose case there has been from birth or from an early age mental defectiveness not amounting to idiocy, yet so pronounced that the child is incapable of managing his affairs or himself or being taught to do so;

(c) a moron child, that is to say a child in whose case there has been from birth or from an early age mental defectiveness not amounting to imbecility, yet so pronounced that the child requires care, supervision, and control for his own protection or for the protection of others."

All three categories here were coupled under the term "feeble-minded child," and indeed we can see language that points to the wording in the MSD's application forms dating

\footnotetext{
${ }^{54}$ Spencer Page, Report of the Superintendent for Neglected Children of the Province of Saskatchewan for the Year Ending December 31, 1912 (Regina: J.W. Reid, 1913), 15. PAS.

${ }^{55}$ Erika Dyck and Alex Deighton, Managing Madness: Weyburn Mental Hospital and the Transformation of Psychiatric Care in Canada. Winnipeg: University of Manitoba Press, 2017, 73.

${ }^{56}$ Government of Saskatchewan. The Child Welfare Act, 1927, c.60, s.74; R.S.S. 1930, c.231, s.75.
} 
back to 1890 , especially language around "guarding," "managing," and "caring" for themselves as key benchmarks for intellectual disability. The use of the term "defective," which is a broader term encompassing several possible disabilities, as a stand-in for intellectual disability is an important point of slippage here. The criteria for "defectiveness" codified here are entirely intellectual in character, necessitating the inclusion of intellectual disability in the characterization of any child barred for reasons of physical disability or bodily difference - a jump that McDermid regularly made. The Saskatchewan government, and Alberta before them, had simply codified what Howard McDermid began practicing in 1909. While Saskatchewan and Alberta would differ in their eugenic policies throughout the twentieth century, these differences were mostly around sexual sterilization, not institutionalization. Catholic Ministers in Saskatchewan's Liberal and Coalition governments in the 1920s, 30s, and 40s would prevent the province from sterilization policy, but raised few objections to institutionalization. ${ }^{57}$ Provinces solved the tension between intellectual disability and compulsory education through a separate system of institutionalization that was bathed in the language of liberal educational thought, but in practice operated as what Veronica Strong-Boag has called "replacements for, and extensions of, families."

\subsection{Conclusion}

Howard McDermid's rejection of deaf and disabled as well as hearing but nonverbal children did not happen in isolation, and the work of Binet and others was disseminated by practicing doctors and bureaucrats around North America. But it did

\footnotetext{
${ }^{57}$ Dyck and Deighton, Managing Madness, 72-74.

${ }^{58}$ Veronica Strong-Boag, Fostering Nation? Canada Confronts Its History of Childhood Disadvantage. (Waterloo: University of Waterloo Press, 2011): 35.
} 
spark concern in Saskatchewan and Alberta about where to place children that McDermid deemed uneducable - politically, institutionally, and legally. It is indicative of a growing precarity between educators of deaf children, Deaf organizations, and the eugenics movement in the early twentieth century, especially after the National Association for the Deaf's campaign against a ban on deaf marriages was successful. ${ }^{59}$ Deaf organizations and educators of deaf students had long drawn a line around deafness as a "disability" that did not suggest ineducability. The intersection between deafness and other disabilities resulted in harder and sharper lines being drawn around the deaf student as oral or signing, but able in every other way, to the exclusion of those who did not fit into this ideal deaf student mould. The practices of exclusion at the Manitoba School for the Deaf before 1923 forced Alberta, Saskatchewan, and Manitoba to develop working definitions of difference that could mark, through legislation, the boundary lines of educability for disabled deaf and hearing children.

\footnotetext{
${ }^{59}$ For responses in Deaf communities to eugenics and the complicated record of Deaf advocacy for those who bore the brunt of eugenic policies, see Melissa Malzkuhn, "Compromising for Agency: The Role of the NAD during the American Eugenics Movement, 1880-1940." In .In Our Own Hands: Essays in Deaf History 1780-1970, eds. Brian H Greenwald and Joseph J. Murray. (Washington, D.C.: Gallaudet University Press, 2016), 171-192.
} 


\section{Chapter 7 - Toward Another Saskatchewan School for the Deaf: The WCAD, Progressivism, and Transformations in Humanitarian Thinking, 1921-1931}

"There is no silence in my hands."

Joanne Weber, Saskatchewan deaf educator and writer, $2013^{1}$

"It is not pleasant to observe how artificial our system is, and to be convinced that no natural system would serve our turn."

Walter Bagehot, $1867^{2}$

"I have never shrunk from doing what I consider to be my duty."

David Peikoff, $1942^{3}$

\subsection{Introduction}

After the closure of the short-lived Saskatchewan School for the Deaf in Regina in 1916, Saskatchewan and Alberta students returned to the Manitoba School for the Deaf in Winnipeg. The three provincial governments had provided a salve for the issue of the 1924 Manitoba tuition hike by agreeing to work toward the "McDermid plan," in which each province would contribute different institutions toward the education and training of Prairie "dependent" children. ${ }^{4}$ With the MSD's move to freed-up buildings in the University of Manitoba’s Agricultural College in 1914, overcrowding at the Portage and Sherbrook school was mitigated for only a few years, and by 1921, the Saskatchewan government was again having to inform Saskatchewanians that their deaf children would

\footnotetext{
${ }^{1}$ Joanne Weber, The Deaf House, 128.

${ }^{2}$ Walter Bagehot, The English Constitution (New York: Oxford University Press, 2009 [1867]), 194.

${ }^{3}$ David Peikoff to Duncan McArthur, Ontario Minister of Education, September 10, 1942. R.J.D. Williams Papers, Box 1 Correspondence, 89-71 UAA.

4 "Dependent" was agreed to mean deaf, blind, and "feeble-minded" children.
} 
have to be put on a waitlist for enrolment in Winnipeg. ${ }^{5}$ Despite the alleviation of overcrowding through opening of an expanded Manitoba School for the Deaf in 1922, the Liberal government of James Gardiner began to work toward the establishment of a school in 1928. Gardiner's Departments of Education and Public Works worked with the Western Canadian Association for the Deaf(WCAD), which had appointed R.J.D. Williams in 1927 as its designated leader in its campaign to pressure Saskatchewan to build a school. The result of this collaboration was a tour of American deaf schools by Williams, a Department of Education bureaucrat, and a representative of the Saskatchewan Grain Grower's Association (SGGA) - one that was partially directed by the efforts of David Peikoff, a founding member of the WCAD and the student President at Gallaudet College in Washington, D.C.

This "sociological tour" was a collaborative effort between Gardiner's government and the WCAD that featured important input from deaf Prairie leaders. The tour attempted to establish the North American professional and methodological norms that had emerged at provincial and state deaf schools, as decisions needed to be made about employee salaries, specific infrastructural needs in deaf schools, vocational education, and where Saskatchewan would find itself in the oral vs. combined educational debate. The Saskatchewan school would be founded in 1931 along lines very close to the wishes of the WCAD and R.J.D. Williams, although the school that would come to bear Williams' name in 1982 moved rapidly towards an entirely oralist outlook

\footnotetext{
${ }^{5}$ F.J. Reynolds to Samuel Latta, Minister of Education, letter, November 3, 1921. Provincial Archives of Saskatchewan (PAS), Samuel Latta Fonds, M5 IV.50. Reynolds, the Superintendent for Neglected Children in Saskatchewan, estimated that only 39 of the 57 eligible children from the province were currently attending the MSD in Winnipeg.

${ }^{6}$ The term is from Kerry Alcorn, Border Crossings: U.S. Culture and Education in Saskatchewan, 19051937 (Montreal and Kingston: McGill-Queen's University Press, 2013), 33, but is a revised version of the "grand sociological tour" found in Daniel T. Rodgers, Atlantic Crossings: Social Politics in a Political Age (Cambridge: Belknap Press, 1998).
} 
by the 1940s. The achievement of the Anderson government and the WCAD, in establishing the school during the first two years of a Depression and agricultural crisis that severely damaged the fiscal and social bedrock of Saskatchewan, shows the emerging power and influence of the WCAD and their Progressive allies, especially journalist Violet McNaughton. This chapter will examine the political influences that saw the province through in its effort to create and maintain the school in terrible economic times - the Women's Wing of the Grain Grower's Association, the contradictory educational legacy of J.L.M. Anderson himself, the WCAD, and the concerted efforts of David Peikoff from Gallaudet to direct the tour toward those elements in American Deaf education that were most aligned with the efforts of American deaf communities.

The successful campaign to found the Saskatchewan School for the Deaf also represented a reprieve from the humanitarian lens through which hearing people and officials had experienced deaf issues. The active involvement and leadership of the WCAD in the push for the school from 1927-1931 represents a temporary shift in the "without us" calculus that informs my use of the term "humanitarianism," as deaf citizens did help to plan and design an educational institution that served other deaf and the deaf community. The WCAD deftly sought hearing allies in progressive movements that were receptive to deaf involvement and resistant to old-party patronage that could subsume the needs of an SSD to partisan machine politics. The group elevated their own concerns with their own public efforts and used powerful allies to amplify them. The WCAD sought out progressive sinews that linked the rural areas of the province, namely the SGGA and the Western Producer, in order to both find deaf children and build a political consensus for spending precious resources on a new deaf school amidst a crushing 
depression after 1929. These achievements were significant, and contribute to our expanding understanding of the political agency of disabled and deaf people before the blossoming of the 1970s disability rights movement.

\subsection{Progressivism and Saskatchewan Politics}

The story of the transition toward a provincial solution for the deaf educational problem in Saskatchewan is, in part, informed by the spread of Progressive ideas in Saskatchewan. Progressivism was a two-track intellectual movement that had purchase on different parts of the political spectrum. The impulse to modernize in order to spark economic growth- or elevate expert control over government, was shared by figures on the left and right, including Conservative Robert Borden and Progressive John Bracken. ${ }^{7}$ The other aspect of progressivism - the pursuit of redistribution in order to decrease income equality and promote social stability - was pursued by progressives on the left end of the spectrum. ${ }^{8}$ Progressive ideas had educational and political applications that featured an elevated role of both experts in public policy and the family as the site of a "unique form of social order that fulfilled itself in its dissolution - in the release of grown children, now self-governing adults, into the society." " Eric Rauchway argues that it was in the family that Progressives sought to pursue their goals of transforming traditional liberalism into a movement that "would permit a definition of social responsibility" beyond liberal individualism. ${ }^{10}$ In an educational context, Progressivism emerged as a force for recognizing the individuality of child learning and developing a child's unique

\footnotetext{
${ }^{7}$ For the defining discussion of Borden's progressivism, see R. Craig Brown, Robert Laird Borden, 18541914 (Toronto: MacMillan, 1975).

${ }^{8}$ Mann, Sources of Social Power Volume 3, 65.

${ }^{9}$ Eric Rauchway, The Refuge of Affections: Family and American Reform Politics, 1900-1920. (New York: Columbia University Press, 2001), 4.

${ }^{10}$ Rauchway, The Refuge of Affections, 3-4.
} 
character, rather than simply focussing on rote learning. ${ }^{11}$ Kerry Alcorn argues that Progressive education was already established in Saskatchewan by the 1920s, though Alcorn argues that it had arrived "quite some time" before the interwar period. ${ }^{12}$ They also argue, however, that given the paucity of evidence for what was actually taught (and how) in Saskatchewan classrooms, it is difficult to qualify how Progressive Saskatchewan's educational system was. ${ }^{13}$ The literature on Progressive education in Saskatchewan remains divided on this question.

The influence of Progressivism is more apparent in the push toward a deaf school in Saskatchewan during the late 1920s. Progressives championed the role of experts as a conduit between the family and the state, as intervention became seen as a way to safeguard the interests of individual children. The founding of the Bureau of Child Protection in Saskatchewan fulfilled this only partly - as legislation allowed for local amateurs, under the guise of Children's Aid Societies only loosely affiliated with the province, to remove children from dangerous familial circumstances and then, later, locate deaf, blind, and intellectually disabled children for specialized training or accommodation. As we will see, a coalition of Progressives within the government, the Western Canadian Association for the Deaf, and the Grain Grower's Association pushed for the state to supersede the Bureau in the case of deaf students in the late 1920s, to allow the opinions and practices of experts to be brought to bear on their educations.

Progressivism in Saskatchewan sought to elevate educational issues "above politics" by enshrining experts with a "common faith in educational science" in the

\footnotetext{
${ }^{11}$ Paul Axelrod, The Promise of Schooling: Education in Canada, 1800-1914. (Toronto: University of Toronto Press, 1997), 57.

${ }^{12}$ Alcorn, Border Crossings, 115.

${ }^{13}$ Alcorn, Border Crossings, 89.
} 
educational bureaucracy. ${ }^{14}$ Harold Foght's Survey of Saskatchewan Education, which appeared in 1918 and was based on the American's research in the province during 1916 and 1917, helped push Saskatchewan officials toward rural school consolidation and away from local control of school curricula. ${ }^{15}$ Foght was employed at the Bureau of Education in Washington, D.C. at the time, and was contracted by the Martin government to produce a survey that would help the province overcome problems linked to local control and funding in rural schooling. Foght championed a focus on "present and future problems," which, for Saskatchewan, meant a concerted focus on preparing students to learn about scientific and managerial improvements in agriculture. ${ }^{16}$ While rural schooling in the province was slow to move away from the practices of rote learning and continued to struggle with local control of educational curricula in immigrant block settlements, Foght's influence began to indirectly push the provincial government toward expanding its control over deaf education. The reality of the practice of sending students to Winnipeg, conditional upon overcrowding rates there, frustrated this impulse, however, until the late 1920s.

Overcrowding plagued the MSD before its relocation in to a permanent building in 1922. Superintendent of Child Protection F.J. Reynolds, in letters to Premier W.M. Martin, argued that the Manitoba government was giving preference to students from that province, and that at least fifteen students were not attending in Winnipeg who should have been. Reynolds was reacting to a letter from Superintendent Lilley at the MSD, who informed Reynolds that two Saskatchewan students had been withdrawn by their parents and asked if "there is any law regarding compulsory education of deaf children of

\footnotetext{
${ }^{14}$ Alcorn, Border Crossings, 109.

${ }^{15}$ Alcorn, Border Crossings, 93.

${ }^{16}$ Alcorn, Border Crossings, 112.
} 
Saskatchewan." ${ }^{17}$ Lilley pointed to overcrowding at the MSD and suggested that these students would lose their place to make room for students on a waiting list if the Saskatchewan government did not act to invoke law in their case. Reynolds wrote to Martin to ask whether Saskatchewan had a compulsory statute, even though he argued that he was loathe to charge based on it, as the children's parents seemed to reject their children's education. ${ }^{18}$ Reynolds also reported that Lilley predicted that the overcrowding crisis at the MSD would continue in the new building. "The Superintendent," Reynolds wrote, "was very much afraid that the accommodation being provided now will not be sufficient to take all our children, particularly if the list increases." ${ }^{19}$

Lilley was right. Not all Saskatchewan students could be accommodated in the new MSD, especially as applications from Alberta and Saskatchewan increased every year from 1921 to $1924 .{ }^{20}$ The province's inability to place all students, as well as their unwillingness to force parents to send their children to Winnipeg, pushed the new Western Canadian Association of the Deaf to pass a resolution at its first convention in 1923 that all deaf children be educated under a compulsory scheme. ${ }^{21}$ The situation as it stood, under the Children's Protection Act, was untenable and increasingly at odds with Progressive influence in the Saskatchewan Department of Education. It was also a continuation of hearing humanitarianism which the WCAD began to mobilize against in the mid-1920s. From the WCAD's point of view, if the Saskatchewan government was

\footnotetext{
${ }^{17}$ H. Gordon Lilley to F.J. Reynolds, January 31, 1921. PAS, Department of Ed Correspondence 19221929, GS 56.

${ }^{18}$ F.J. Reynolds to W.M. Martin, February 3, 1922. PAS, Department of Ed Correspondence 1922-1929.

${ }^{19}$ F.J. Reynolds to W.M. Martin, November 3, 1921. PAS, Department of Ed Correspondence 1922-1929.

${ }^{20}$ Student Files - Admission Applications (Ab-Zm) 1890-1939. Provincial Archives of Manitoba (PAM), Winnipeg, E 0197A Box 1 GR 4531. Applications show that the numbers were - 1921: 16, 1922: 19, 1923: 22, 1924: 24.

${ }^{21}$ Charles White to Deputy Minister of Education, "Western Canadian Association of the Deaf, Resolutions." October 26, 1923. Department of Ed Correspondence 1922-1929.
} 
unable to educate all of the province's children, then the governance of education needed to change. If the government was unwilling to ensure the right to education to all of its citizens, then the public and sympathetic figures in the government needed to be convinced through politics and publicity.

\subsection{Imagining the Saskatchewan School for the Deaf, 1927-1929}

The Gardiner Liberals opted for a deaf and blind school in 1928 as a way to build a provincial institution that would showcase Saskatchewan's growing status, ensure that all deaf children were educated, and that the province would no longer be subject to the kind of inter-provincial disagreement that arose from tuition hikes after the elections of the Manitoba Liberals in 1915 and John Bracken's United Farmers of Manitoba in 1922. Gardiner walked back from provincial blind education, however, as Saskatchewan's terms with the Ontario School for the Blind in Brantford remained more stable, and the province moved away from building a separate blind school after the 1929 Reports from the spring tour unanimously rejected educating deaf and blind students together.

1923 was a pivotal year for the Saskatchewan Liberals on the deaf education issue. On August 14, 1923, Manitoba Premier John Bracken wrote Saskatchewan Minister of Education Samuel Latta to propose that "in view of better equipment that has provided in our school for the deaf that an adjustment of the arrangement that has been in effect for a number of years should be considered." ${ }^{22}$ Bracken proposed a meeting with Education Ministers from Saskatchewan and Alberta to negotiate new terms. At a meeting in Winnipeg, Bracken sought to increase the costs to the other two Prairie provinces, arguing that due to Manitoba's new and larger school, costs should increase for all

\footnotetext{
${ }^{22}$ John Bracken to Samuel Latta, August 14, 1923. PAS, Samuel Latta Fonds, M5 IV.50. Strike-through in original.
} 
provinces sending students to Winnipeg. This conflict pushed Saskatchewan to take seriously the prospect of once again opening its own School for the Deaf by September 1923. Deputy Minister Ball, in a September 14 letter to Minister Latta, argued that "I think the question should be raised at the approaching meeting as to whether it would not be advisable to educate these children in Saskatchewan. ${ }^{, 23}$ Ball proposed that Saskatchewan could propose a model of four local centres around the province where deaf educators would come to the children where they were, within local school systems. Ball could have been introducing a bit of bluff into Saskatchewan's positioning in order to extract better terms from Manitoba, but his letter clearly envisions a serious model for the province to pursue.

A report from Acting Superintendent of Neglected Children Phenix to Ball, commissioned that same month, made clear that the new MSD had not resulted in all students from the province going to Winnipeg. In fact, two fewer Saskatchewan students were attending in 1922-23 that did in 1921-22, and at a greater per-capita cost. ${ }^{24}$ Saskatchewan sought to enter negotiations with the twin positions of eliminating waitlists and not raising the provinces' costs. Bracken eventually relented on cost, but not on waitlists, and Saskatchewan ended up paying an increase that was less than Bracken envisioned. This compromise failed to address the issue of uneducated deaf children, however, and criticism of the government of Charles Dunning over deaf schooling continued throughout his 1922-1926 tenure.

\footnotetext{
${ }^{23}$ A.G. Ball to Samuel Latta, September 14, 1923. PAS, Samuel Latta Fonds, M5 IV.50.

${ }^{24}$ Acting Commissioner Phenix to Deputy Minister Ball, September 10, 1923. PAS, Samuel Latta Fonds, M5 IV.50 In 1921-22, 47 students from SK attended at a per capita cost to the government of $\$ 666.40$, while in 1922-23, 45 students attended at a per capita cost of $\$ 694.88$.
} 
James Gardiner, who became Premier in 1926, was an educational reformer with a deep interest in administrative educational issues, having been a teacher, and duly sought to overhaul provincial educational funding to ensure that both local school boards and the Department of Education be properly funded through a more centralized system that increased provincial oversight into local education. ${ }^{25}$ Gardiner's political identity remained resolutely Liberal, and while he had refused to break with Wilfrid Laurier's national party in 1917 and resisted cooperation with the Progressive and United Farmer's Parties throughout his political career, he sought to incorporate Progressive policies into his Liberal platform to bring in the types of voters who fled the Alberta and Manitoba Liberal parties for United Farmers governments in the early 1920 s. ${ }^{26}$ Gardiner's unwillingness to cooperate with the UFM pushed him toward a provincial institution for deaf education by 1927 , on the basis of province-building, as opposed to the "regionbuilding" approach suggested by the "McDermid plan" of the late nineteenth and early twentieth-centuries. Gardiner sought to realize province-building in a Saskatchewan that became Canada's third most populous province in the 1920s, astride increasing levels of immigration, and seemed poised to finally win access to the proceeds of its own natural resources from the Liberal government in Ottawa. ${ }^{27}$ Saskatchewan had also recovered economically from the post First World War depression, and was enjoying a provincial economic and debt financing situation that was the envy of even the other Western provinces by $1928 .^{28}$

\footnotetext{
${ }^{25}$ Ward and Smith, Jimmy Gardiner, 63.

${ }^{26}$ Ward and Smith, Jimmy Gardiner, 61.

${ }^{27}$ Ward and Smith, Jimmy Gardiner, 61. Resource control would come in 1930 under Anderson's government on terms already rejected as too weak by Gardiner in 1929.

${ }^{28}$ Patrick Kyba, "Ballots and Burning Crosses - The Election of 1929," in Politics in Saskatchewan, Ward and Spafford, eds, (Don Mills: Longman, 1969), 107.
} 
The province was continually forced to focus on deaf education by the Western Canadian Association for the Deaf. The WCAD was founded in order to advocate for deaf employment rights, the preservation of sign language in deaf education, and the expansion of deaf education to accommodate post-secondary study in a Canadian context. ${ }^{29}$ The initial executive included Peikoff, R.J.D. Williams, and George Riley of British Columbia - three important figures in the establishment of the Saskatchewan School for the Deaf between 1928 and 1931. In 1927, the Association elected Williams as an official liaison with the Saskatchewan government to push for the establishment of a school in Saskatchewan. ${ }^{30}$ Williams was charged with the responsibility of surveying the province of Saskatchewan to find deaf children who were not enrolled in the Winnipeg or Montreal (MacKay) Schools, and use the resulting statistics to pressure James Gardiner's government to work toward a provincial solution to the problem of compulsory schooling violations. He was also empowered by the Association to offer the government advice and guidance if it moved toward a policy of re-establishing a Saskatchewan School for the Deaf. ${ }^{31}$

Williams' correspondence with Premier Gardiner, F.J. Reynolds, the Department of Education, and journalist Violet McNaughton pushed a receptive government toward the establishment of a new school beginning in 1927. WCAD efforts to pressure the government predated Williams' election, however. In October of 1923, the WCAD sent its first resolutions to the Deputy Minister of Education. These pushed for the complete enforcement of Saskatchewan's compulsory schooling laws, and challenged the province

\footnotetext{
${ }^{29}$ Winnipeg Evening Tribune, June 22, 1923, 3.

${ }^{30}$ Proceedings of the Third Triennial Convention of the Western Canadian Association of the Deaf, Vancouver, B.C., June 26-July 1, 1929. (PTTCWCAD) Provincial Archives of Saskatchewan, Regina. S-A1 E17, "Deaf, 1929-1952."

${ }^{31}$ PTTCWCAD, 15-16.
} 
to ensure that "every parent, guardian, or other person, having control of any normal child between six and twenty years of age, too deaf and too dumb or defective of speech or hearing to be materially benefitted by the methods of instruction in vogue in the public schools, shall be required to send such child or youth to the School for the Deaf at Winnipeg." 32 By 1928, Williams had sent the results of the WCAD's survey of uneducated deaf youth in the province, along with several letters, to F.J. Reynolds. These initial letters seem to have been unanswered, and Williams wrote directly to Premier Gardiner on the topic in May of 1928. The Department of Education wrote Reynolds on May 3,1928, giving him only two days to produce the WCAD report on compulsory schooling violations, which he sent on the same day. ${ }^{33}$ Gardiner's direct interest in the issue stemmed from a new urgency in the deaf educational issue, given that the province had already passed legislation working toward school establishment in March of that year.

The WCAD's message was firm from 1927 to 1931: Saskatchewan could not effectively ensure that compulsory legislation was being followed without a provincial school. While the WCAD did not directly call out Reynolds for burying correspondence, the implication of WCAD messaging was that the Bureau of Child Protection under Reynolds was not equipped to ensure that every deaf child would attend school in Winnipeg or Montreal. The Department of Education needed to take control of Deaf education exclusively for two reasons: first that the $\mathrm{BCP}$ was a loose network of local Children's Aid Societies that lacked centralized control, and, more importantly, that the education of deaf youth needed to be overseen by the same bureaucracy as the education

\footnotetext{
${ }^{32}$ Charles White to Deputy Minister of Education, October 21, 1923, 2. PAS, Samuel Latta Fonds, M5 IV.50.

${ }^{33}$ F.J. Reynolds to Deputy Minister Ball, May 3, 1923. PAS, Department of Education Correspondence, 1922-1929.
} 
of hearing children. ${ }^{34}$ The WCAD's vision, then, was the founding of a deaf school that would operate under the Department of Education in the same legal manner as schools for hearing children, with a greater emphasis on specialized training for teachers and vocational training. Williams envisioned, by moving the oversight of the school to the Department of Education, expert oversight that would end the province's longstanding humanitarian response.

The WCAD also corresponded with Violet McNaughton and urged her to publish a long article on the deaf education issue in June of 1928. Her article covered Williams' speech to the United Women's Section of the SGGA that month, in which he reported his and David Peikoff's findings about American responses to the Act of 1927, and asked the Women's Section to throw its support behind the WCAD in its efforts to push the government to ensure that deaf education was free, available past the age of sixteen, conducted under a combined method program, and compulsory. "Is there a woman here..." McNaughton commented, "who could rest content if she knew there were children in the province imprisoned; shut off from the world around them? From the standpoint of the woman and the mother it is an intolerable situation, and the very upmost must be done to open the world of language, and the soul of life to the deaf children of Saskatchewan. ${ }^{, 35}$ McNaughton tapped into two currents of thought here: that of maternal feminism and that of deaf rhetoric around the importance of sign language as a way for deaf children to enter the world. Williams, in his speech, was reported by McNaughton to have quoted an American deaf teacher in making the case for deaf schools along the latter

\footnotetext{
${ }^{34}$ David Peikoff to James Gardiner, June 16, 1928. PAS, Correspondence Regarding Education of Deaf and Dumb and Blind, 1922-1929, 97G.

${ }^{35}$ Western Producer, June 28, 1928. PAS, Department of Education, 15. School for the Deaf Correspondence, 1922-1940, GS 56.
} 
lines. "The deaf child's mind," the teacher wrote, "is a veritable prison house from which there is no escape until the key of language has been given him...his mental life, his industrial salvation, his very soul he finds at school. ${ }^{, 36}$ Deaf children, McNaughton argued in the piece, were in greater need than hearing children of an intensive education, because they needed to access written English and marketable employment skills through specialized education in order to ensure their attainment of "self-sufficiency."

The article, and Williams' speech, went far beyond merely a call for compulsory deaf education, however. Williams presented criticisms, from hearing and deaf American educators at deaf schools, of Saskatchewan's legislation. American responses, he reported, were overwhelmingly negative, and "not one reply was commendatory." Williams dismissed the model of educating deaf and blind children together as problematic, because "there is nothing in common between them." He also argued that making deaf education compulsory only until the age of sixteen held back the possibility of deaf Saskatchewanians attending post-secondary institutions, or even graduating with the kind of academic, vocational, and linguistic skills that they would need to compete in the job market, especially in the printing industry, where he had been employed in Winnipeg and Saskatoon since he had left the MSD. Williams argued that while the legislation did not obliquely preclude students from attending after the age of sixteen, the fact that parents would have to pay fees after that age meant that most children would, in fact, leave at sixteen. "We would humbly beg the provincial authorities to replace this

${ }^{36}$ WP, June 21, 1928. 
section 9 with another which would make it clear that education shall be free to all the deaf children between the ages seven and twenty, inclusive," Williams submitted. ${ }^{37}$

The WCAD sent a clipping of the article to the Department of Education in 1928 and kept up a correspondence with McNaughton throughout the process of founding the SSD. After the Gardiner government announced that $\$ 300,000$ would be appropriated for the school's construction, George Riley thanked McNaughton for her help in drawing up publicity for the WCAD's efforts to engage with the government. On January 29, 1929, McNaughton praised Williams in her self-effacing reply. "I am sure I never expected to have so much made of my small assistance which I have given Mr. Williams," she wrote Riley, "I certainly could not have done it if he did not have the things lined up so well, he certainly has worked like a bear.",38

McNaughton's publicity for Williams and the WCAD's efforts was well placed the Western Producer was a primary organ for the Grain Grower's Associations on the Prairies, the Saskatchewan wing of which counted several members of Gardiner's government in its ranks, including Gardiner himself. ${ }^{39}$ The SGGA's advocacy for the establishment of an SSD followed Progressive doctrine - both in a political and educational sense. The WCAD, though, had pushed the SGGA to pay attention to deaf educational concerns through McNaughton. Before the 1928 article, the SGGA had not given much attention to deaf educational issues. Indeed, a 1923 SGGA report on

\footnotetext{
${ }^{37}$ WP , June 21, 1928. Williams' speech was read aloud by Mrs. George Hollis in his presence, and a former MSD teacher interpreted for the audience and Williams during the question period that followed.

${ }^{38}$ Violet McNaughton to George Riley, January 29, 1929, letter. PAS, Violet McNaughton Papers, S-A1 E17, Deaf, 1929-1952.

${ }^{39}$ David Smith, "James G. Gardiner," in Saskatchewan Premiers of the Twentieth Century, ed. Gordon L. Barnhart, (Regina: University of Regina Press, 2004), 93.
} 
education called for the province to "provide a school for the blind in Saskatchewan," but did not comment on the state of deaf education in the province. ${ }^{40}$

Gardiner's government passed Bill 79, which committed the province to establish a deaf school, on March 7, 1928. The government struggled to establish the school, however, because of the province's initial wish to have blind and deaf students educated together, an idea opposed by both deaf and blind communities in the province. In early 1929 , the Gardiner government appropriated $\$ 300,000$ to establish the school and fund a fact-finding mission with MPs and the WCAD. This tour was a way to resolve the disagreements between the government and the WCAD on the issues of sign language instruction and co-education of deaf and blind children. ${ }^{41}$

David Peikoff, former President of the WCAD and a student at Gallaudet since 1924, was also central to the Association's efforts to lobby the government before and after the spring 1929 tour of the United States. He kept up a frequent correspondence with a variety of government officials from 1927 to 1931, using his residence at Gallaudet to seek out and submit the opinions of American deaf educators, send new relevant literature to the government, and to argue for the establishment of a Saskatchewan school that would create more educational opportunity for deaf youth than the Manitoba school alone. He also offered strong defenses of the combined method and, like Williams would do in his 1929 report, architectural and leadership suggestions for a new SSD based on his own experiences at the MSD as a child and young adult.

In his first letter to Premier Gardiner, Peikoff congratulated the government on its 1928 legislation and argued that the establishment of a deaf school was an important

\footnotetext{
${ }^{40}$ SGGA Provincial Council of Women, "Report on Education, 1923," 4. PAS, Samuel Latta Fonds, M5 IV.50.

${ }^{41}$ Carbin, Deaf Heritage, 161.
} 
benchmark for a sub-national polity. "A roll call," Peikoff wrote in his introductory letter to the Premier, "would at once disclose that practically every Province in the East boasts of at least one school for the deaf, and in the United States virtually every state in the Union maintains one or more substantial, up to date residential school. ${ }^{42}$ State-building rhetoric was an effective lever pulled by the WCAD throughout the SSD founding process.

The Gardiner Liberals, Anderson Coalitionists, WCAD, and SGGA all began to see the issue of founding an SSD through a state formation lens by the late 1920s. Overcrowding at the MSD had not been solved by the construction of the large campus in Winnipeg by 1922, and Saskatchewan continued to struggle with jurisdictional issues and the Manitoba government's push to increase out-of-province tuition fees to deal with the MSD's increased infrastructural costs. Both Gardiner and Anderson supported the legislature's ambition, following the 1928 Act, to build a provincial school as a marker of Saskatchewan's emergence as a wheat-growing power whose economic fortunes were improving with agricultural commodity prices. The state-building impulse was enough for the province to continue the SSD project even after the collapse of commodity markets after 1929.

The WCAD pushed the province to look more directly at the prospects of deaf students within Saskatchewan's educational system. Deaf children and youth needed to be incorporated into that system to ensure that the goals of the province's compulsory education policies would be realized. The WCAD advocated for deaf students to be incorporated into the same educational bureaucracy as hearing students, by taking them

\footnotetext{
${ }^{42}$ David Peikoff to James Gardiner, June 16, 1928. PAS, Correspondence Regarding Education of Deaf and Dumb and Blind, 1922-1929, 97G.
} 
out from under the purview of the Bureau of Child Protection and placing their system within the Department of Education. They placed certain conditions on this advocacy that the province adhere to an educational and institutional standard that was common in other provinces and states that operated deaf schools, hire deaf teachers, and practice a combined method. When the Gardiner government decided to launch a tour of deaf schools in Canada and the United States to prepare for the establishment of the SSD, the WCAD, and especially Williams, had made themselves visible and integral enough to the province's planning to be directly included.

\subsection{The Rhetorical Power of State-Building: Williams' Correspondence with Parents}

Parents of deaf children in Saskatchewan received disheartening letters from the provincial government in 1927. The MSD was at capacity, and new students would be sent to the McKay School for the Deaf in Montreal. In 1927, Williams and the WCAD sent out a circular letter to deaf parents in the Western Producer. Over the next three years, Williams received dozens of letters from parents that can help us understand the strain that the province's inconsistent commitment to deaf education put on families. Williams seems not to have sent these letters directly to the provincial government, but did allude to them in correspondence with Premier Gardiner and in pieces published by MacNaughton and himself in the Western Producer.

Most parents, writing between 1927 and 1929, highlighted their disappointment

that the province was slow to build its educational and institutional capacity. Nearly all of the twenty-six parents who wrote Williams argued that building a provincial deaf school 
was Saskatchewan's responsibility. "We sure would be glad to build it up," wrote H.K. Wiebe about a new SSD. ${ }^{43}$ "I think it is about time," Alex Sjolin wrote,

that our province should take steps to have a school of our own it seems to me that they are doing a lot toward looking after the Education of the hearing children why not do a little more for the Deaf because they need education more than the hearing children and I think it is up to the parents and all others interested in the unfortunate deaf to take this matter up with the Minister of Education and also with the Members of our Provincial Parlement (sic) ${ }^{44}$

As I argued in Chapter Four, hearing responses to the WCAD circular campaign shows that hearing parents feared their children's departure for Winnipeg or points further East, and appealed to the idea that their children needed special educational provision in order to thrive in a liberal order. This was the humanitarian side of a hearing response to the school issue. The state building rhetoric, however, offered a hearing perspective that fused humanitarian and rights perspectives. This rhetoric, seemingly informed by the wording of the WCAD's circular letter itself, did not stress that deaf children should be accommodated in existing educational structures, or "mainstreamed" in twenty-first century parlance. It made a unique appeal to building a separate system as a worthy pursuit of a kind of state-building that would herald the demographic and economic growth of Saskatchewan itself.

The 1927 WCAD circular argued that publicizing their campaign was easier than finding deaf children out of school. A major problem facing compulsory enrolment in regional deaf schools was the refusal of farm families to separate themselves from their children's presence and labour. The WCAD announced a way to deal with weaknesses in

\footnotetext{
${ }^{43}$ Axel Sjolin to R.J.D. Williams, December 30, 1927. Box 1 Correspondence, Williams Papers, UAA. ${ }^{44}$ Mr. and Mrs. Wiebe to R.J.D. Williams, September 12, 1927. Box 1 Correspondence, Williams Papers, UAA.
} 
rural governmentality and the reluctance of farmers to send their children to Winnipeg and Montreal. "The writer believes," the circular stated,

that the United Farmers of Canada with its numerous local lodges may be able to do something for the welfare and future happiness of deaf children by appealing to the parents, or guardians, to see that the child gets an early start in school. It is the desire of the Western Canadian Association of the Deaf to locate all deaf children of school age or under, and keep track of them. This has been a difficult thing to do, so if all farm people knowing of any such child, took the trouble to inform the Association, it would gladly send particulars to the parents in regard to sending the child to the proper school. ${ }^{45}$

Williams knew that the province was not fulfilling its mandate, through the BCP, to do this work. He also knew that the true public sinews of rural Saskatchewan were the UFC and the Western Producer. By the end of 1927, Williams was able to send the BCP a list of deaf children and youth out of school in the province, largely gathered through the circular and UCP campaign. As we have seen in the preceding section, $\mathrm{BCP}$ Superintendent F.J. Reynolds was slow to respond to the WCAD's campaign to gather information that he should have been overseeing. Only when Williams wrote to the Department of Education to ask if the BCP had received his correspondence was the province embarrassed into acting.

As we have seen, this fusing of rights and humanitarian rhetoric was a brief recrystallization of institutional and cultural practice around deaf educational practices around in Saskatchewan - a rare time when political power rose to override ideological and economic power, to use Mann's model of the mechanics of social power. This was fleeting, as we will see. Still, the years from 1927-1931 were ones of surprising hearing receptiveness to deaf issues. This openness was largely achieved through the political and public campaign of the WCAD.

\footnotetext{
${ }^{45}$ R.J.D. Williams, "Educating the Deaf Child," The Western Producer, August 1927. Clipping, Williams Papers, Box 2 Scrapbooks.
} 


\subsection{The Sociological Tour: The Spring 1929 Reports}

In the spring of 1929, the Gardiner government organized a tour of Canadian and American deaf schools. Like other sociological tours of the era, the tour's goal was to elevate the issue of deaf education beyond partisan politics by studying the practices that prevailed at existing schools. It was, in short, a quintessentially progressive activity, a reconnaissance mission to establish the currents of expertise that the province needed to swim towards in building an SSD. The tour was composed of representatives from the provincial government, the WCAD, and the SGGA. The resulting reports weighed in on the location, pedagogy, architecture, and student composition of the SSD being imagined by the government and the WCAD. It was a unique opportunity for Williams and the WCAD to influence provincial state formation in the interest of deaf citizens.

The tour was itself a suggestion of an earlier WCAD report on American responses to Bill 79 that the Association sent to Gardiner in the autumn of 1928, though it is entirely plausible that the Saskatchewan government would have undertaken it as an established practice before a major policy decision. David Peikoff, on behalf of the WCAD, authored the 1928 report to James Gardiner. It was withering in its criticism of the Bill, and Peikoff's research and correspondence made it clear that Saskatchewan's plans to educate deaf and blind children together until the age of sixteen would "involve the Province in needless trouble after those objectionable provisions have been tried out." ${ }^{, 46}$ Educators who filed reports were also critical of the Act's claim that "the maintenance and support of such persons (the student) shall be the duty of the parent or

\footnotetext{
${ }^{46}$ Western Canadian Association of the Deaf, "Opinions of Leading American Educators of the Deaf on Bill 79 of 1928," 1. PAS, Department of Education, Correspondence Regarding Education of Deaf and Dumb and Blind, 1922-1929, 97G. The report is undated, but it seems to have been received in the autumn of 1928.
} 
legal guardian requiring his admission. ${ }^{, 47}$ Gallaudet College President Dr. Percival Ball wrote that "the maintenance and support of all deaf and blind children sent to such schools should be paid from public funds, whether such children are above or below the age of sixteen years. There is no question but that all children are entitled to an elementary education at the cost of tax payers. ${ }^{.48}$ Bill 79 , as drafted, was far out of the mainstream of deaf schooling legislation in North America in this respect, and the Liberal government, at the time of its drafting, was still forming a vision of deaf education as part of a wider compulsory education scheme paid by taxpayers in the same manner as hearing children. Clearly, the WCAD report helped push the Saskatchewan government toward an inclusive, rather than charitable, educational system for deaf Saskatchewanians. The WCAD's effort to have the Department of Education control the school was an important suggestion that sought to make it clear that the SSD would not be an ameliorative asylum. This claim links both progressive political ideas and a common struggle being undertaken by deaf leaders and organizations throughout North America to push a "process of legitimization," as historian Susan Burch calls it. ${ }^{49}$ Burch argues that American deaf associations and educators argued to have the words "dumb" and "asylum" removed from state publications and titles, and launched a successful campaign to "standardize definitions of deafness. ${ }^{50}$ While Burch locates this struggle as one around nomenclature, it was also about the veracity of a financial and fiduciary claim within the political economies of provinces and states - as asylums were seen as ameliorative and prone to underfunding and invisibility from the public sphere.

\footnotetext{
${ }^{47}$ WCAD, "Opinions," 8.

${ }^{48}$ WCAD, "Opinions," 11.

${ }^{49}$ Burch, Signs of Resistance, 34-35.

${ }^{50}$ Burch, Signs of Resistance, 34.
} 
The four-member committee undertook its tour between March 25 and April 5 of 1929. Williams had received leave from his printing job, and both he and Hollis received the promise of financial reimbursement from the province for ten days. Attendees were provided with letters of introduction, and the schools on the schedule had been notified of the Saskatchewan delegation's visit in advance. After the tour, the government received reports from the WCAD's Williams, the SGGA's Annie Hollis, the Department of Education's N. Latour, and government architect M.W. Sharon. Sharon's report dealt with architectural standards, Hollis' on student health and vocational training for female students, Williams' on methods and administration, and Latour's was more of a summary of the four reports, as well as an appraisal of the kind of plan that he thought the province could achieve. ${ }^{51}$

R.J.D. Williams' report likely drew on his experience more than on his findings during the tour. He began with thirteen suggestions that he expounded on over his report's fifteen pages. Williams' primary suggestions for the government were that the school fall under Department of Education control, the Superintendent "should not be a 'one method man,"' and the government appoint an outreach worker to engage with hearing parents about deaf education and work for the employment of deaf graduates. ${ }^{52}$ Williams also brought up concerns over the Act's extension of compulsory attendance to the age of sixteen, arguing that it should be raised to nineteen and the school should be located close to the University of Saskatchewan to allow for the possibility of deaf students taking classes there after graduation. To make this point, Williams posited that

\footnotetext{
${ }^{51}$ N. Latour to Deputy Minister Ball, "Re School for the Deaf," 1. PAS, Department of Education Correspondence Regarding Deaf, Dumb, and Blind, 97G.

${ }^{52}$ R.J.D. Williams, "Report," 1-2. PAS, Department of Education Correspondence Regarding Education of Deaf and Dumb and Blind, 1922-1929, 97G.
} 
in order to be both compulsory and effective, deaf education could not operate under the same time-to-completion expectations as hearing public schools. He explained that this was because deaf students had to spend time becoming familiar with sign language and written English (and for some, spoken English) before working on academic and vocational training. ${ }^{53}$ Deaf education was an expensive, but necessary investment, Williams argued. He echoed the position he outlined at his SGGA speech the year before, where he argued that "It is not possible to educate the deaf as cheaply as the children who can hear, since the cost is about five times greater, but even this is not too much for the purpose of enabling the deaf to make their way into the world after graduating." 54

Williams also weighed in extensively on the methods controversy. He did not see speech and lip-reading to young students in their first two years as effective, but supported the combined method in order to keep Saskatchewan from adopting strict oralism if only presented with the Manichean options of manual and oral. "Whether or not oral training slows up the pupil's progress in the first couple of years," Williams wrote, "and is the cause of the lengthy course required for the average student, and has increased the cost of educating the deaf, is open to debate. However, since the parents demand that their children begin under the most difficult method of training (oral), I can see no reason why your Government should hesitate in going to every expense to make the school a real success. ${ }^{, 55}$ Interestingly, Williams framed the methods debate as in the community's rear-view mirror. He argued that those students in the initial oral stream should not be segregated from older signing students, as this became a practice "during a time when there was over-enthusiasm for pure oral training," and that it would "retard the

\footnotetext{
${ }^{53}$ R.J.D. Williams, "Report," i.

${ }^{54}$ R.J.D. Williams, quoted in $W P$, June 21,1928 . PAS, 97G.

${ }^{55}$ R.J.D. Williams, "Report," 2-3.
} 
progress of those who have not the reasonable ability to learn to speak." 56 He placed some emphasis on the fact that the oral stream increased the cost of deaf education through a greater need for teachers, likely to make the implicit point that making the school purely oral would result in a greater cost to the government.

Vocational programs were central to the reports filed by Williams, Hollis, and Latour. Williams and Latour argued that in addition to printing instruction and carpentry for male students, Saskatchewan should start a program of agricultural training at the new school, which was rare in the schools that they visited. "Until our cities grow larger, with more industries, many of the deaf will have to return to farm life and they should be prepared accordingly," Latour wrote. ${ }^{57}$ American schools had abandoned agricultural training, Williams and Latour wrote, but the demographics of Saskatchewan should have dictated that the government prepare students for their most likely occupations: agricultural labour and farming. Latour's report also stressed the benefit of student vocational labour to the school's bottom line, while both Williams and Hollis stressed that student vocational training should not be seen as an economic boon only, as the temptation for the province to jeopardize classroom time would cause academic development for students to suffer. Annie Hollis quoted Superintendent Rodwell of the MSD as saying that vocational programs were, in many schools, "a convenience to the institution rather than a means of education...vocational work should be placed on a purely educational basis." ${ }^{58}$ Williams and Hollis strove to avoid building a deaf education that did not foreground the school's educational character, and argued that in order for an

\footnotetext{
${ }^{56}$ Williams, "Report," 3.

${ }^{57}$ N. Latour, "Re School for the Deaf," 16.

${ }^{58}$ Mrs. George Hollis (Annie) to James Gardiner, April 5, 1929, 8. PAS, Department of Education Correspondence Regarding Deaf, Dumb, and Blind, 1922-1929, 97G.
} 
SSD to be part of a progressive program of compulsory education that would accommodate deaf students, it could not be viewed in the same vein as other provincial asylums that benefitted from inmate labour.

SGGA representative Annie Hollis argued for the importance of the school's educational and opportunity-levelling character. An SSD, she argued, was necessary to "fit them (students) for future citizenship and in preparing them to become selfsupporting." ${ }^{, 59}$ The cost would be high but without education students would "become a burden and cost to the State in their adult years, and would never have derived much pleasure or satisfaction from life. ${ }^{, 60}$ Hollis' view was that the province needed to establish a school, rather than an asylum, in order to prepare students into the liberal order, and that this was a uniquely important process for deaf students. Hollis argued that part of establishing a school, rather than an asylum, was in recognizing that an SSD would be "taking the place of the child's own home," though she didn't define what she meant by "home." ${ }^{\prime 61}$ Hollis emphasized the importance of dress alteration as a viable occupation for girls, rather than domestic service - a common but undesirable occupation for deaf women in England and Canada from the early nineteenth-century. ${ }^{62}$

While Hollis and Latour focussed primarily on establishing a school that would train deaf students to live within a liberal order that stressed self-sufficiency, Williams emphasized the larger ties within the Saskatchewan deaf community that a school would forge. He recommended "That all positions in the School where hearing is not absolutely

\footnotetext{
${ }^{59}$ Hollis to Gardiner, April 5, 1929, 2.

${ }^{60}$ Hollis to Gardiner, April 5, 1929, 2.

${ }^{61}$ Asylums were also homes, though the idea that they offered surrogate domesticity was no longer taken seriously by the 1920 s.

${ }^{62}$ See Tom Mitchell and Reinhold Kramer, Walk Towards the Gallows: The Tragedy of Hilda Blake, Hanged 1899 (Toronto: University of Toronto Press, 2007).
} 
necessary be filled by deaf persons of good character. ${ }^{, 63}$ His recommendation that the province appoint an outreach worker to educate deaf parents reflected his interest in combatting impressions of deaf people and sign language as transgressive, and is indicative of Burch's idea of a "process of legitimization." ${ }^{64}$ It can also be seen as a push back against humanitarian impulses in hearing interactions with deaf people. Williams also saw deaf teachers as performing an important part as role models for students, as he had worked to do at the MSD as student Supervisor and a Printing Instructor who worked at newspaper presses in Winnipeg and later Saskatoon. His proposed field outreach position would also involve "open(ing) avenues of employment for the deaf by educating employers regarding the abilities of the deaf as workers. ${ }^{965}$ Williams had personally experienced the partial gains won by the MSD and deaf workers in Winnipeg to link education to gainful employment, despite the prejudices of employers in most industries and workplaces.

The SSD would have community-building effects for Saskatchewan's deaf citizens. It is important to point out, also, that Saskatchewan's deaf politics was predated by a regional approach that emerged from the "Further West Deaf" campaign in the 1890s. Joseph J. Murray argues that deaf schools and clubs have been portrayed as "universal, singular vehicles of Deaf cultural transmission," but that the twenty-first century decline of these schools has forced deaf scholars to allow them to be "historicized, to be understood as products of a specific historical moment." ${ }^{, 66}$ The WCAD made an

\footnotetext{
${ }^{63}$ Williams, "Report," ii.

${ }^{64}$ Burch, Signs of Resistance, 34.

${ }^{65}$ Williams, "Report," ii.

${ }^{66}$ Joseph J.. Murray, "Coequality and Transnational Studies: Understanding Deaf Lives,” in Open Your Eyes: Deaf Studies Talking, ed. by H-Dirksen L. Bauman, 100-110 (Minneapolis: University of Minnesota Press, 2002), 103.
} 
argument for co-equality, and this was central to William's argument about deaf teachers and increased government outreach to hearing parents of deaf children. While the late 1920s in Saskatchewan represents the same thing as the late 1880s in Manitoba - the call for public support for the founding of a deaf school - the 1920s struggle was undertaken on different terms. Hearing allies were still necessary, but an elite group of deaf professional men and women, educated at the MSD and, in numerous cases, Gallaudet College, was directly involved and made a more expansive and considered study of the school's purpose and possibilities. It was a picture that included, but transcended, a liberal perspective that focussed on individual deaf children's training and futures.

The reports justified the founding of the school - in terms that mostly reflected purely individual liberalism - that could ensure, as Williams wrote, that the SSD be "the best (school) in Canada from the very beginning. ${ }^{, 67}$ All argued that in order to meet the legislative promise of compulsory deaf education, deaf youth and children needed to be included within a school that was specialized but legally equivalent to hearing public schools. These reports highlighted tensions between building more inclusive links between education, work, and citizenship and the segregated nature of residential deaf schooling. The reports agreed that the school should be an educational institution, not an asylum, but it also would spend more time on vocational education than hearing schools. It needed to combine manual and oral methods, but also to ensure that all students emerged with a command of written English.

Peikoff and Williams separately recommended that the province hire Edwin Gallaudet Peterson, a hearing Michigan educator who grew up in a family with deaf

${ }^{67}$ Williams, "Report," 3. 
parents, as the school's first Superintendent. Peikoff wrote the government on April 30 to reiterate his support for Peterson, arguing that he was the best possible hire and was respected by the WCAD membership. After outlining the key attributes of a good superintendent - "fine foresight" and willingness to appoint "only eminently fitted helpers" were cited by Peikoff - he argued that Edwin G. Peterson exemplified them all. ${ }^{68}$ Peterson was hired by the Anderson government in 1930.

Gardiner received these reports but work toward establishing the SSD stalled with the 1929 election campaign. As both Premier and Minister of Education in 1929, Gardiner quickly became distracted from the push for the school, although key decisions were made before Gardiner's agonizingly narrow defeat. The school would be in Saskatoon, it would be controlled entirely by the Department of Education, and it would be a large residential school and not a series of local centers where deaf students would be "mainstreamed" within hearing schools. In these three decisions, Gardiner's government would follow the advice of the WCAD.

After the formation of Anderson's coalition government of Progressives and Conservatives, the WCAD received more requests for input from the province. On October 4, 1929, WCAD representatives led by Williams met with the new provincial cabinet. The WCAD feared that the new government would dictate the location and staffing of the school along the familiar lines of partisan patronage, and Williams' notes for the day show that the Association went into the meeting with well-crafted arguments in favour of following expert advice in these matters. The new cabinet, that featured

\footnotetext{
${ }^{68}$ David Peikoff to A.G. Ball, Deputy Minister of Education, April 30, 1929. PAS, Department of Education Correspondence Regarding Education of Deaf and Dumb and Blind, 97G.
} 
several of Anderson's Progressive coalition partners, were persuaded to abide by the Liberal decisions on location, jurisdiction, and student accommodations. Saskatoon, Williams argued, was a central location where qualified educators would want to live. "The deaf children," his notes state, "deserve a good staff in a good location." 69 The WCAD was also concerned with avoiding a school in an isolated location that would diminish student activity, like the Alberta Training School near Red Deer, Alberta. Deaf children needed to associate with deaf adults and groups and not be totally isolated from the hearing public, the WCAD's position stated. Williams also argued in favour of Saskatoon so that deaf graduates could attend courses at the University of Saskatchewan, as Canada did not have a deaf university like D.C.'s Gallaudet College.

\subsection{Historiographical Considerations}

The active involvement of the WCAD in the government's planning for a new SSD is remarkable. Historians of deaf education and deaf communities have argued that the early twentieth-century, especially after the First World War, was a time of declining influence for deaf people in the organization and operation of institutions that they interacted with. Susan Burch, Douglas Baynton, and Joseph Murray in the United States, as well as Martin Atherton in the UK, have argued that deaf communities became more devolved as the oppressions visited upon deaf people by the hearing multiplied. ${ }^{70}$

\footnotetext{
69 "Arguments presented to the Cabinet Ministers at Conference between Government of Saskatchewan and WCAD representatives at Legislation Buildings, Regina, Oct 4, 1929, 1. Williams Papers, Box 1 Correspondence, UAA.

${ }^{70}$ Burch, Signs of Resistance, 110-111; Douglas Baynton, Forbidden Signs; Martin Atherton, Deafness, Community, and Culture in Britain: Leisure and Cohesion, 1945-1995. (Manchester: Manchester University Press, 2012.), 42-43. By “devolved" I mean here that deaf organizations began to selfconsciously move from charitable, hearing-led organizations like the Association in the Aid of the Deaf and Dumb (AADD) in Britain to deaf-led organizations that represented the interest of deaf communities with local governments while organizing political, social, and religious life in deaf communities. Atherton argues that this process was set off by the late nineteenth-century distancing of the Church of England from
} 
Existing local deaf organizations began to organize nationally in the United States and Britain in the early twentieth-century, with the establishment of the National Association of the Deaf in the U.S. the British Deaf Association in the UK at the same time, in reaction to the need for a national response to local pressures against deaf linguistic, insurance, and employment opportunities and rights. Oralism, eugenic attitudes about deaf inter-marriage, and rising fears of subcultures and linguistic diversity were all resisted by national and sub-national deaf organizations, and deaf people were increasingly seen by governments as transgressive entities to be shaped and managed rather than consulted. ${ }^{71}$ The Saskatchewan experience differed from the American, British, and Eastern Canadian trends at this time, as the WCAD had a great deal of influence in creating public will for the school, researching and imagining what it could and would be, and implementing plans in the school's construction and operation. This would change after the late 1930s, as oralism and hearing teachers overtook the school.

By the 1950s, the Saskatchewan School for the Deaf employed no deaf teachers in academic departments, and sign language was outlawed from classrooms. Most new teachers did not know sign language, similar to the string of political appointees that served as Superintendents after Edwin Peterson's resignation in 1937. Protests and petitions from hearing parents of deaf students had pressured the province to move away from the combined method established by Superintendent Peterson in the early 1930s. The SSD would only begin to reverse this in the 1970s, when student protests began to

the issue of sign language rights in education, which it had forcefully supported for centuries. Burch interprets this movement as a product of an emerging educated deaf elite in the United States. The WCAD, directed mainly by educated male graduates of the MSD and Gallaudet who worked in the printing trade, is well-explained by the process suggested by Burch.

${ }^{71}$ Baynton, Forbidden Signs, 9. 
force the school to move toward Total Communication and eventually American Sign Language. $^{72}$

The rise and decline of oralism and the deaf community's active ability to shape provincial policy traces a similar arc over the first half of the twentieth century than that of progressive education's influence in Western Canada drawn by Lynn Lemisko and Kurt Clausen in their examination of curriculums in Ontario and Alberta between 1930 and $1955 .^{73}$ Lemisko and Clausen argue that progressivism had achieved its zenith of influence during the 1930s, but declined in importance for provincial education planning by the late 1940s. Susan Burch also argues that progressivism likely worked against oralism and the marginalization of deaf voices in planning, because the approach favoured by John Dewey, that children's individuality and personal needs by reflected in the curriculum they undertook, undercut oralists' core principles. ${ }^{74}$ The decline of progressivism in the late 1940 s - and a return to systematic, shared, rote learning matches a decline in deaf advocacy and sign language instruction at the MSD and SSD. The brief success of the WCAD in influencing the Saskatchewan government may, then, reflect a moment of cultural openness during the progressive era that quickly closed as progressive ideas lost their purchase - a brief softening of usually-hardened hearing paternalism towards deaf people and communities. It is difficult to ignore the fact that many of the WCAD's goals in Saskatchewan in the 1920s were similar to those in

\footnotetext{
${ }^{72}$ Carbin, Deaf Heritage in Canada, 167-168. Total communication was a system of instruction that incorporated simultaneous speech and signs using English grammar (known as Signed Exact English). Total communication was used in many North American Deaf Schools in the 1970s and 80s, until studies in Gallaudet University's Linguistics Department convinced many adherents of its flaws. See footnote 3, Chapter One.

${ }^{73}$ Lynn Speer Lemisko and Kurt W. Clausen, "Connections, Contrarieties, and Convolutions: Curriculum and Pedagogical Reform in Alberta and Ontario, 1930-1955." Canadian Journal of Education 29, no. 4 (2006): 1097-1126.

${ }^{74}$ Burch, Signs of Resistance, 32.
} 
Manitoba forty years earlier - sign language recognition, educational rights, and employment opportunities.

The experience of the WCAD in government planning between 1928 and 1931 does also, however, solidify Susan Burch's overall conclusion in Signs of Resistance. Burke argues that despite hearing oppression, deaf people and organizations successfully kept oralism and eugenic practices from becoming ubiquitous. They did this through advocacy that was largely defensive. ${ }^{75}$ Deaf Americans and Canadians won significant rights in the early twentieth century through organizing, including the rights to work in civil service, drive, and take out insurance policies at market rates. While oralism was at the height of its power in the immediate postwar period, deaf organizations and activists did resist its complete application, and laid the groundwork for a more successful resistance in the 1970s. The WCAD's power in provincial decision-making might represent a last-gasp of provincial consultation with deaf organizations, or it might instead be considered to be the first step in a long relationship between deaf advocates and the province that provided increasingly diminishing returns for the amalgamated Canadian Association for the Deaf, especially in 1991 when the SSD was closed by the Devine government. This study concludes with this first concerted salvo by the WCAD, so it is unable to evaluate these questions.

\subsection{Saskatchewan Politics and the 1929 Election}

The Liberals, by 1929, had been in power in the province since 1905. James Gardiner, by the time of his ascendance to the Premiership in 1926, inherited a machine

\footnotetext{
${ }^{75}$ Burch, Signs of Resistance, 168.
} 
government from Charles Dunning that had used patronage in the civil service and the Saskatchewan Provincial Police, as well as the appointment of leaders in the SGGA to Cabinet, to weather the storm of Progressive farmer's parties that had toppled Liberal governments in Alberta and Manitoba. ${ }^{76}$ Gardiner's government, in particular, incorporated populist politics into its electoral platform, including proportional representation, increased state involvement in medicine, and unemployment insurance. ${ }^{77}$ Gardiner, however, was a thoroughly Liberal partisan who held contempt for Progressives - one that was only heightened in September 1929 when newly elected Progressive MPs entered a new Coalition government with J.L.M. Anderson's Conservatives.

James Gardiner was committed to the establishment of provincial solutions to educational problems, especially given his disdain for the United Farmer's governments in Manitoba and Alberta. ${ }^{78}$ Deaf education offered a way to move forward with educational policy beyond the deadlock around Catholic and French education opposition to which helped to strengthen the coalition between Progressive and Conservative politics during the 1929 campaign. While this issue does not seem to have been at the forefront of Gardiner's mind in the late twenties, his government moved to solve the issue of a Saskatchewan-centred response to the issue of deaf and blind education by 1928 .

J.T.M. Anderson's record showed an affinity with educational issues, as he had written and consulted extensively on Saskatchewan's growing educational system.

\footnotetext{
${ }^{76}$ Norman Ward and David Smith, Jimmy Gardiner: Relentless Liberal. (Toronto: University of Toronto Press): 84-85; Richard Johnston, The Canadian Party System: An Analytic History. (Vancouver, UBC Press, 2017), 139.

${ }^{77}$ Ward and Smith, Jimmy Gardiner, 149.

${ }^{78}$ Ward and Smith, Jimmy Gardiner, 88-89.
} 
Anderson was particularly concerned with the growth of immigrant populations in rural areas and argued for an end to all non-English instruction. This perspective, supported wholeheartedly by the SGGA in 1923 and merged well with a wave of Anglo nativism and Klan membership in the province in the late 1920s. As we have seen, Anderson supported Gardiner's vision for an SSD in 1929, and, in an interesting bookend, he was appointed Superintendent of the SSD by T.C Douglas from 1944 to his death in 1946. Anderson, however, showed little interest in an SSD during the campaign, but likely envisioned it as a way to increase the educational infrastructure of the province, respond to his Progressive allies who propped up his government from 1929 to 1934, and to realize English assimilation of deaf immigrant children.

After a close and contentious election, the Gardiner government lost its majority status in the Legislature and fell to Anderson's Conservative-Progressive coalition. ${ }^{79} \mathrm{He}$ was elected, in part, on a program of Anglicising schools as a nation-building project. $\mathrm{He}$ also swept in to power on the cusp of a strong wave of Anglo nativism and Ku Klux Klan activity in Saskatchewan in the late 1920s ${ }^{80}$ James Pitsula has framed this wave as an aftershock of strong Anglo nativism and nationalism that crested with the First World War and especially the movement toward Union government in $1917 .{ }^{81}$ Anderson was critical of cultural and linguistic diversity in schooling and made himself Minister of Education in addition to Premier. During the campaign, Anderson was especially critical of the practice of allowing French instruction in public schools beyond Grade One, a compromise with Anglo nativists brought in by the Martin government in 1918. He

\footnotetext{
${ }^{79}$ Waiser, Saskatchewan, 245.

${ }^{80}$ James Pitsula, Keeping Canada British: The KuKlux Klan in 1920s Saskatchewan. (Vancouver, UBC Press, 2013), 202; Keith McLeod, "Politics, Schools, and the French Language, 1881-1931," in Politics in Saskatchewan, Norman Ward and Duff Spafford, eds. (Don Mills, Longmans, 1968), 135-138.

${ }^{81}$ Pitsula, Keeping Canada British, 1-2.
} 
constructed a campaign narrative that wedded criticisms of the Gardiner government's acceptance of "sectarian" influence in schooling and the support of Catholic and immigrant voters for the Liberal machine government. ${ }^{82}$ The Conservative campaign's distrust of non-English instruction led the WCAD to fear that Anderson would scrap the project, but they were pleasantly surprised when he committed to an increase in provincial funding for the deaf school to $\$ 800,000$ in October of $1929 .{ }^{83}$

The fact that Anderson's government was propped up by a coalition with Progressives does not completely explain why he decided to go this particular route. Indeed, the SGGA had inroads with Progressive elements in the Legislature. It is more important to point out that Anderson and his Conservative legislators did not see a deaf school as a threat to Anglo identity in the province in the same way as they saw Catholic, Ukrainian, and French schools. The example of the Manitoba School for the Deaf would have been a positive one for Saskatchewanians who were motivated by the anti-French and immigrant rhetoric in the Conservative Party - as the school represented an institution where students of many different ethnic and religious backgrounds converged under a manually spelled and spoken English curriculum. ${ }^{84}$ MSD application records show that between 1890 and 1931, fifty-one applicants were identified as immigrants with Russian Orthodox, Jewish, Moravian, Mennonite, or Lutheran instruction specified as preferred by parents. At least two dozen more had German, Finnish, Russian, or Ukrainian surnames but did not specify a preferred religious course of worship and study. If religious instruction and first or second-generation Canadian status can be seen as corresponding with the use of a different language in the home, it is clear that a

\footnotetext{
${ }^{82}$ Waiser, Saskatchewan, 250.

${ }^{83}$ Carbin, Deaf Heritage, 162.

${ }^{84}$ Application Admissions, 1890-1939.
} 
significant number of MSD from Alberta and Saskatchewan were receiving concerted English instruction for the first time there, aside even from the small number of Francophone Catholic students and a few Indigenous and Métis students.

\subsection{The Depression: Repurposing Federal Dollars for Provincial Fiscal Stimulus}

Beginning in 1930, Saskatchewan began to experience a multi-faceted economic and environmental crisis that plunged the province into a severe fiscal and social downward spiral. The collapse of wheat prices led to both financial hardship for individual farm families and the public coffers. In January of 1931, the first of a series of dust storms began to push farmers in the dryland south toward the edge of the boreal forest to find more arable land, though many also fled their farms to find work in the cities. ${ }^{85}$ The ensuing Depression affected Saskatchewan more severely than many other provinces, given its over-reliance on the production and sale of a single commodity, wheat, whose price had declined precipitously since 1929 and offered the average farmer $80 \%$ of their cash income. ${ }^{86}$ The Anderson government began to offer both direct subsidization of local relief efforts and provincial funding as stimulus to offset the worst aspects of urban unemployment.

Much of the money spent on urban work projects was offered by R.B. Bennett's Conservative government between 1930 and 1932. Anderson redirected federal dollars to finance the construction of a number of infrastructure and Public Works projects in Regina, Saskatoon, and Moose Jaw. Bennett's federal Public Works program financed this construction as a way to help avoid the collapse of urban municipalities in the province that were groaning under the strain of public relief payments and declining tax

\footnotetext{
${ }^{85}$ Waiser, Saskatchewan, 281.

${ }^{86}$ Waiser, Saskatchewan, 281-282.
} 
revenues. The Anderson government had already appropriated $\$ 800,000$ to construct the SSD, though this amount was halved by the time the buildings were complete in 1931 .

Despite the financial strain on the provincial government, construction was helped by the Anderson government's commitment to providing temporary construction work when it could, and federal dollars that attempted to stimulate provincial economies.

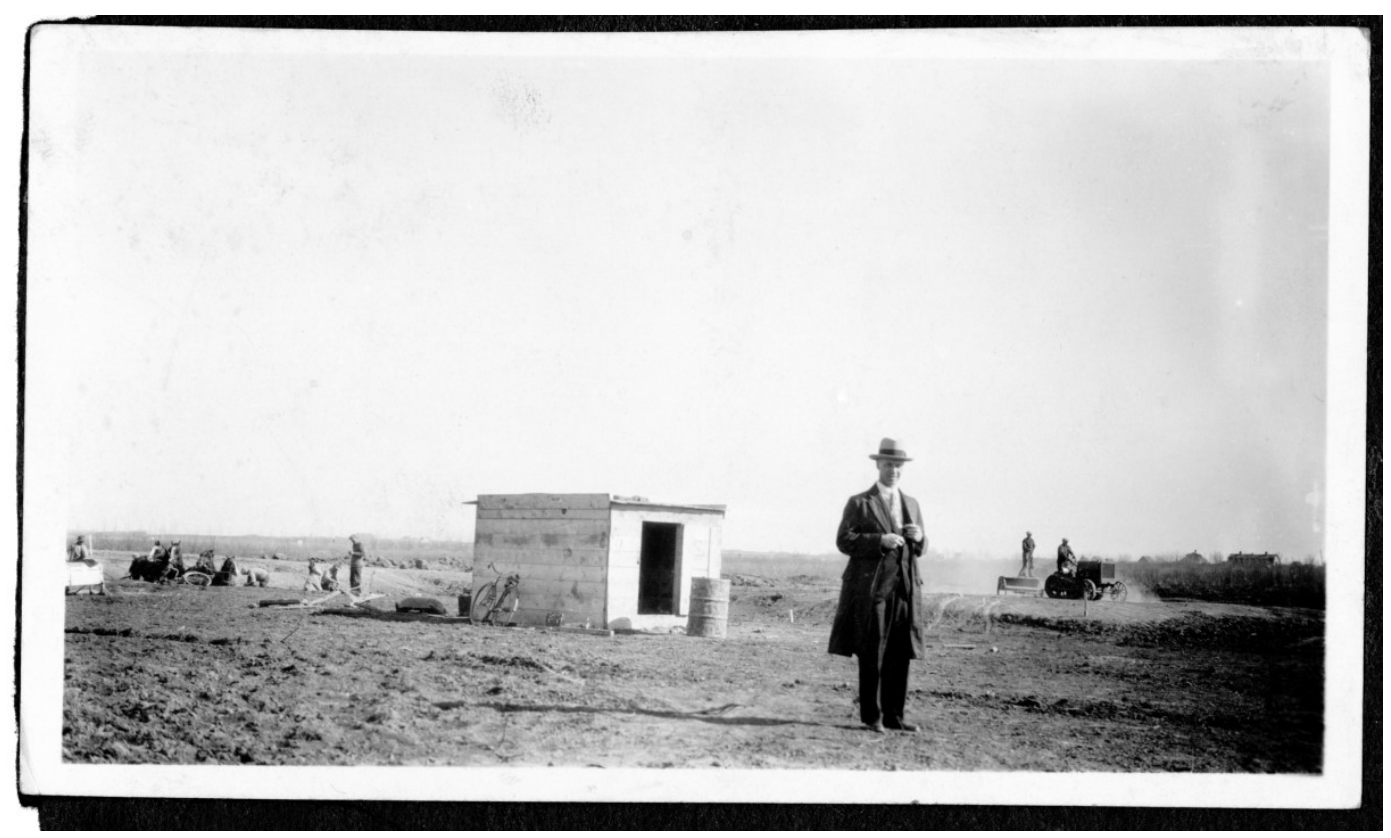

Figure 7.1. R.J.D Williams at the site of the future SSD, Saskatoon, Saskatchewan, 1930. Photo by Myrtle Williams. R.J.D. Williams Papers, Box 2 Scrapbooks, UAA.

The SSD's timing was good. Construction was completed before 1932, when the Bennett government cancelled the federal Public Works program. The Anderson government also continued to commit to the school's operation as part of a larger effort to keep educational funding stable and reliable throughout the crisis. While teachers' 
salaries dropped, few were laid off and schools of all types were kept open. ${ }^{87}$ This helped the SSD weather the economic and political crisis that it was born into. Even though salaries fell below a level that would attract educated and experienced deaf educators, Saskatchewan was not alone in lowering salaries, and there was no exodus of teachers after pay cuts, either in the deaf or hearing educational systems.

When the SSD opened in September 1931, the Depression had hit families with deaf students hard. Despite rosy government publicity in local papers upon the school's opening, R.J.D. Williams painted a grim picture of the school's fiscal condition. As the new Supervisor of the Boy's Dormitory, he reported that "In 1931 our government was so short of money that people hired as houseparents had to carry all beds, mattresses, and protable (sic) lockers from the basement to the dormitories. Students, arriving, in many cases, had insufficient clothing and so the Red Cross gave assistance. ${ }^{.88}$ Still, the WCAD's morale was high in the fall of 1931. The SSD represented a tangible, meaningful success for the organization. As Williams put it in his address to the SSD staff in 1972, "What a thrill it gave people who had campaigned for a new School for the Deaf to see the new building plans to be pursued...in spite of the hard times we all had a happy time. ${ }^{89}$

\subsection{Conclusion}

In the late 1920s, Saskatchewan moved to deal with a central disconnect in its 1917 compulsory education policy: that the provincial state was not equipped with a

\footnotetext{
${ }^{87}$ Waiser, Saskatchewan, 296.

${ }^{88}$ R.J.D. Williams, "Address at the Staff Members, Closing Exercises, School for the Deaf, Saskatoon, June 21, 1972," 1. Box 1 Correspondence, Williams Papers, UAA.

${ }^{89}$ Ibid.
} 
centralized system of accountability for educating deaf and blind students in the same way that one existed for hearing students. The province also soured on the unending bureaucratic battles with Manitoba over sending students to Winnipeg and sought to adopt a solution to these problems that would also serve the province-building goals of the Gardiner government. The government was pushed toward these solutions by the Western Canadian Association of the Deaf in the late 1920s, and the school that emerged reflected the wishes and goals of the WCAD to a large extent. It also represented a concerted, if temporary, step away from the humanitarian impulses that had informed government decision making in deaf education before 1928. Aided by a federal Public Works grant and an emerging consensus on building provincial institutions across both Liberal and Coalition governments, the Saskatchewan School for the Deaf opened in 1931. 


\section{Chapter Eight: Conclusions}

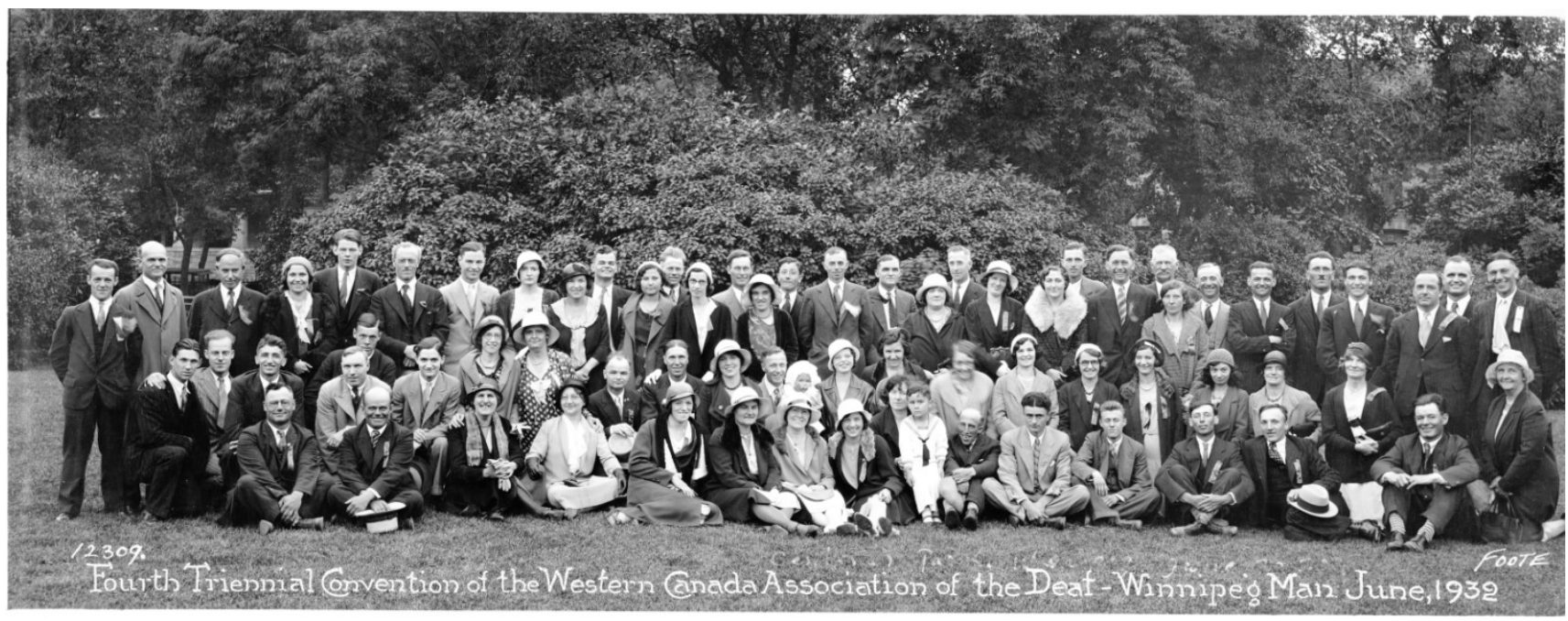

Fig. 8.1 Portrait, 1932 WCAD Convention. WCAD Papers, UAA.

\subsection{Introduction}

Leaving the stately Marlborough Hotel in downtown Winnipeg, WCAD

convention-goers likely walked down Smith Avenue toward the grounds of the Provincial Legislature, some 15 minutes away by foot. Posing for the organization's triennial portrait, after a long convention day, both men and women were dressed up in suits, dresses, and convention ribbons as they formed three rows together. The Superintendent of the new Saskatchewan School for the Deaf, Edwin Peterson, crouched beside David Peikoff, fourth and third from the left in the middle row, respectively. Myrtle and R.J.D. Williams, with their new baby girl, sat at the center of the middle row. The Association had a great deal to celebrate that summer. In the three years since their last convention, the WCAD had pressured the Saskatchewan government to found a school, advised the government on its nature, founded a scholarship fund for Western Canadian students 
attending Gallaudet, made initial plans for a deaf settlement colony in Saskatchewan, successfully fought a ban on deaf driving in British Columbia, and attained other achievements. As this dissertation has argued, these milestones represented the fruits of the efforts of a group of young activists who came of age immediately after the First World War, pushing an older generation who organized around leisure and educational activities toward a more political realization of deaf community. They also, unfortunately, represented something of a high water mark in the political fortunes of deaf Western Canadians, as we have seen. One major exception, the 1955 construction of the Alberta School for the Deaf in Edmonton, was darkened by the obstinate oralism practiced within its walls.

Here, though, was a day to celebrate and re-acquaint. While I'm sure that many subjects in this photo suspected that politics would re-orient to begin to claw back some of the political influence recently gained by the WCAD, they could not know it for certain. This leads me to a fundamental question of historical study - how important are movements that succeed incompletely, or succeed in the short-term but fail in the middleterm (the long-term achievements of the WCAD are more mixed)? How should we study a brief moment of surprising optimism that is bracketed by indifference, humanitarian attitudes, paternalism, and linguistic oppression? I would simply answer that we should study these moments with the seriousness and conviction displayed by those who contributed to their making. Outliers in narrative are not merely, as John Prine wrote, "a crooked piece of time."

\footnotetext{
${ }^{1}$ John Prine, “Crooked Piece of Time," Bruised Orange (Elektra Records, 1978).
} 


\subsection{Contributions of this Study}

This dissertation has argued that the process of building deaf education in Alberta and Saskatchewan between 1880 and 1931 shows how the push for educational rights helped to push forward the process of state formation, but also that at key moments, deaf communities and individuals contributed to the design and nature of that formation. In the 1920 s, former institutional crystallizations in deaf education became inadequate in the faces of a new framing of political power in education, namely progressivism, and an emerging young elite of deaf graduates of the MSD and Gallaudet College. The ideological power of hearing humanitarian disregard for the futurity and capacity of deaf people was challenged by new political powers, unmooring a balance that had crystallized an ad hoc arrangement between Manitoba and the two provinces to the west. This sclerotic humanitarianism was troubled, at least with regard to relations between the “organized deaf” and the state, by new political forces. It was re-established by the postwar period, however, by the decline of progressive education and the re-establishment of a humanitarian ideology by hearing parents of deaf children who re-asserted their control over the lives and linguistic futures of their children. The deaf community had been sidelined, yet continued to struggle throughout the 1950 s and 60 s to be heard.

The development of deaf education on the Prairies had also contributed to the construction of intellectual disability, as Superintendents after 1909 navigated the difficult narrows of the emerging eugenic era, choosing to link deafness with educability to the exclusion of other physically and intellectually disabled groups and individuals. The plight of children and adults deemed to be intellectually disabled through much of the twentieth-century was drastic. Sterilization was not practiced across the country, but 
institutionalization was, and as Malacrida's work on the Michener Centre in Alberta has shown, institutionalization was also dehumanizing and perpetuated cycles of physical and emotional abuse. In moving out of the crosshairs of eugenicists, deaf Canadians watched generations of their fellow citizens wallow in institutions for decades. This was not, of course, directly the "fault" of deaf organizations. Deaf organizations, though, did not demonstrably push back.

Deaf education was part of the larger colonial project in Western Canada. Deaf Indigenous people were rarely admitted to the settler deaf education system, and deaf settler Western Canadians overwhelmingly supported the colonial project and saw themselves as a part of it. Indeed, part of deaf politics in the late nineteenth and early twentieth-century was trying to prove deaf citizens as worthy of, and exemplars of, colonial displacement and settlement. The image of deaf settler John Parker being buried in a Union Jack-covered coffin by his fellow Northwest Resistance veterans is merely one example of how many deaf Westerners, and deaf leaders, identified with colonial goals and mythologies.

The hearing humanitarian ethos that runs throughout this study has, therefore, layers. It operated outside of the borders of the colonial ethos that directed genocide on the Prairies and parkland, but was similar in attitude, if not in result or scale. This study, as I have stated, rejects drawing comparisons between the horrors of Indian Residential Schools and deaf residential schools. The former were sites of cultural and personal destruction, while the latter were sites of cultural formation, although much of the labour toward that formation was deaf labour. What Mrs. Thomas Stephens of Saskatchewan called the "absolute indifference of the majority" was part of a larger series of human 
diversities that the liberal order itself had to transform in order to encompass. Those defined outside of the early twentieth-century liberal order - Indigenous people, deaf/disabled people, Black Canadians, women, Jewish and Muslim Canadians, and others - worked to transform that order itself in order to "gain access" to the imagined liberal public sphere. White, propertied, non-disabled men did not merely "open" their ranks to allow others in - those doors were cracked open as they threatened to crumble. This process - especially for Black, Indigenous, and disabled people, goes on. It is not contrary to the zero-sum metaphors employed by pluralist/liberal theory - a straight line. Revanchist periods, like the Trump period we are hopefully emerging from, push back and refract directions.

The late 1930s and immediate post-war period in Western Canada was another revanchist period in which hearing parents and hearing teachers in deaf schools pushed back the limited gains won by the WCAD in the 1920s. The story of deaf education on the Prairies suggests that political change is the result of a combination of contingency, shifts in the dominance of ideological or political power, and socio-cultural trends. Social change, though, is not the only force that colours political developments. The continued "indifference of the majority" has, despite hard political work by deaf Canadians and allies, resulted in a medicalized, mainstream-education state response to deaf children and youth in twenty-first century Canada.

This dissertation also makes contributions to the history of childhood in Canada. Application records filed with the MSD allow us a glimpse into not only humanitarian and rights responses to deaf children's educations, but also into rural social history. Many of the families who applied reported poverty and family breakdown, but also ingenious 
strategies for overcoming these obstacles. Women's formal employment was recognized through application forms by the early twentieth-century, making these strategies more visible to both bureaucrats and twenty-first century readers. Child labour, taken as unremarkable before the First World War, also became more visible through application forms, with many parents describing their deaf children's chores and labour breathlessly. This complicates hard theorizations of deaf futurities imposed by hearing people, as many hearing parents simply saw their deaf children as working toward inheriting farms and living work lives not too distinct from their hearing children.

This study also makes contributions to the history of institutions in late nineteenth and early twentieth-century Canada. Institutions proliferated nationally at this time, principally to provide a practical solution to what contemporary leaders and citizens saw as the problem of dependent children and adults in the liberal order. Though application records do suggest a significant number of (mostly) rural families who resisted sending their children to Winnipeg and Montreal, a larger number of parents seemed eager for their children to receive an education. A number of parents and guardians also reported that the children themselves were eager to attend school, if they were already not enrolled locally.

I have recreated a picture of deaf school life that differs greatly from that of Indian Residential Schools. It is important for hearing scholars and readers to not lump these institutions together. As I have argued, one was a site of cultural genocide and one a site of cultural generation. That is not to say that deaf residential schools were uniformly wonderful places. Sexual abuse, the abuse of student labour, and poor provisions for housing and medical care have been documented both in print and in court. Yet many 
deaf people who reflect on their schooling experiences either value the opportunity to meet other deaf people and "learn to be deaf," or look back in anger at their experiences in mainstreaming, feeling isolation from hearing peers that was only amplified by poor provincial investment in interpretation. This is not a simple conversation to have, and is an area for much more concerted thinking and study by deaf scholars and communities. We should not lump DRS and IRSs together reflexively as similar lived-in educational institutions.

The practice and construction of deaf education in the Prairie West led to particular crystallizations in state formation and institutions. As we have seen, the institutional fact of Dr. Howard McDermid's labeling of prospective students as "feebleminded" forced Alberta and Saskatchewan to codify their own definitions of this diagnosis. These provinces consulted McDermid and his successor in drafting compulsory schooling laws to complement the larger literature and experience that Saskatchewan, at least, gathered during a number of sociological tours through the Western United States. The development of deaf educational schemes in Saskatchewan and Alberta also moved those provinces away from the primarily private, local responses overseen by Departments of Child Protection. Deaf activists, hearing parents, and progressive educators and bureaucrats helped to ensure the reality of compulsory schooling in Saskatchewan by the 1930s, and Alberta slightly later. These are two examples of how bureaucratic, institutional, and political practice around the issue pushed the state to design and enshrine new responses to the issue of educational access for deaf children. 
This study also makes a broad contribution to a formative question in Disability Studies. Is disability, as a conceptual category and social fact, a product of the "capacity" focussed liberal order, of capitalist productivity being enforced on bodies, or a longer running fear of human diversity? This study suggests that the first two causes are historicized responses to older fears of diversity and social transgression. This study alone cannot evaluate such an expansive question. Yet as Disability Studies moves further toward solidifying the origins of disability in capitalism, I feel that it is important to push back and assert the primacy of longer-running human fears of difference. Placing the rise of disability in the nineteenth-century risks a reification of the difficulty of procuring earlier sources into hard theory. It also risks a romantic picture of a preindustrial community. It is possible that we merely see the same fear expressed in different ways in different historical contexts. In Western Canada between 1880 and 1931, that context emerged in a complex humanitarianism that sought to deny deaf Canadians a voice in their own lives and futures, but assented to the use of state resources to ensure a more formal place for deaf children and adults in an emerging liberal order that emphasized education and individual responsibility.

\subsection{Connections to the Present, Conclusions}

In her 2013 creative memoir, Saskatchewan deaf educator Joanne Weber depicts a Regina Association of the Deaf meeting after the closure of the SSD in 1991, a school at which she was a teacher in its final year. As former Ontario MPP and deaf leader Gary Malkowski pumps up the crowd of SSD alumni and supporters, Weber reflects on the prospects of successful resistance to the provincial government's recent decision to close the school: 
Again, more vigorous nods. A man shouted and waved at the back. More hands went up, in unison, to cheer Gary on. I search faces. The Deaf seniors who merely wanted to play cards, dote on their grandchildren, and travel, and thought: They can't take up another cause again. They can't do anything to save the Deaf community or return it to its former glory. Everyone is too old and tired, and the most politically savvy leaders have left the province. ${ }^{2}$

The enthusiasm for Malkowski’s message seems palpable. Attendees vocalize and sign approval as Malkowski made his way through a vigorously signed speech. Yet, Weber writes, senior deaf were signing under tables and seemed too tired to act. She does not give a date for this meeting, but it seems likely that it took place in the early twenty-first century. If so, this generation of deaf Saskatchewanians had been fighting for sign language rights since the 1960s, fought the closure of the SSD, and had worked and raised families in the area. By the time the 1960s/70s activists reached elderhood, there seemed to be few young activists to forge a new kind of direct political action on the deaf education issue like they had in the $60 \mathrm{~s} / 70 \mathrm{~s}$ and their parents had in the $1920 \mathrm{~s}$. The closure of the SSD had resulted in many young Saskatchewan deaf leaving Regina and Saskatoon for Vancouver or Toronto, sites of large, vibrant signing deaf communities. If we look at the 2000s, 1970s, and 1920s generations of deaf activists in Saskatchewan as distinct generations, the narrative allure of commemorating 1970s activists has crowded out the memory of 1920 s organizers, as well as current work being undertaken by young deaf activists. If our only received model of political movements is along the lines of the 1950s and 60s Civil Rights model, we often miss different expressions of challenges to political power. There is, of course, no one way to make a movement.

Ontario has had success in maintaining its deaf schools, at least at the present. Other provinces have closed residential deaf schools in favour of mainstreaming

\footnotetext{
${ }^{2}$ Weber, The Deaf House, 307. Emphasis in original.
} 
programs while enrolments in existing deaf schools are falling. ${ }^{3}$ British Columbia, in May 2020, announced that it was closing two of its innovative deaf preschools. ${ }^{4}$ In 2019 , parents of a deaf child in Newfoundland and Labrador launched a discrimination lawsuit against the province, alleging that his school had no interpreters or teachers who knew ASL. ${ }^{5}$ The fight for the right to an education, at least a good education, for deaf kids is still playing out all over Canada in the neo-liberal era of educational "efficiency"/austerity. Canada now has national disability legislation. Yet that legislation does not directly touch provincial education. Canada still has a discriminatory immigration policy with respect to potential deaf immigrants. Hearing humanitarianism endures in a legal guise, in human rights tribunals, and in mainstreamed classrooms unfit for ASL users. Like Saskatchewan and Alberta from 1905 to the 1930s, access to deaf education was assured by Departments of Education, then enshrined in legislative documents that ensured compulsory education. But access to deaf education was then, and in some places now, dependent upon families having the financial and temporal resources to access the legal avenues through which rights so often flow in the twentyfirst century.

Yet, deaf politics are still with us. As Joanne Weber's memoir makes clear, many of the current fights involve acting against the colonial legacy of deaf education. Though access to deaf education is a problem faced by many Canadian children outside of urban

\footnotetext{
${ }^{3}$ Nova Scotia (and by extension, New Brunswick and PEI) closed its deaf school in 1994, and Newfoundland did so in 2010.

4 "Metro Vancouver preschools for deaf and hard of hearing kids facing imminent closure," CBC News, May 3, 2020. https://www.cbc.ca/news/canada/british-columbia/metro-vancouver-preschools-for-deaf-andhard-of-hearing-kids-facing-imminent-closure-1.5554184 (accessed August 4, 2020).

5 "Deaf child's parents to launch human rights hearing against N.L. school district," CTV News, August 15, 2019. https://www.ctvnews.ca/canada/deaf-child-s-parents-to-launch-human-rights-hearing-against-n-lschool-district-1.4551830 (accessed August 3, 2020).
} 
mainstreaming programmes (and even within many of those), large chasms still prevail between Indigenous and settler children's access. Weber's fictional fellow deaf teacher exclaims, when an Indigenous deaf student who does not sign or speak is brought to her deaf classroom - "We're going to sweat blood for this kid.", This also extends beyond simple access, and involves forging closer ties between deaf settler and deaf Indigenous people and communities. Linguists and deaf academics in Canada are working to create and maintain bridges to Indigenous communities and Indigenous Sign Languages. ${ }^{7} \mathrm{My}$ interventions into the debate on whether deaf settler Canadians are complicit in Canada's colonial past is undertaken with these currents in mind, not with a vision of singleminded blame. I am, I hope, following the leadership of Canadian deaf scholars and activists in studying intersections between settler and Indigenous deaf pasts, as well as the historical conditions that drew a veil between them.

The hearing public in Western Canada, and in Canada as a whole, is still steeped in humanitarian attitudes toward deaf people. Provincial governments spend millions on ensuring the opportunity for post-secondary students like myself to take a degree (or minor degree) in American Sign Language, but do little to connect hearing parents with ASL training or deaf communities. ASL acquisition, in increasingly mainstreamed Canadian educational systems, remains poorly supported in an era of cuts to education and a never-ending search for "efficiency.", Austerity has hit all areas of education, but deaf students have been among the hardest hit. Deaf education continues to be defined

\footnotetext{
${ }^{6}$ Weber, The Deaf House, 285. It's not clear when this occurred, but it would have been in the twenty-first century.

${ }^{7}$ Kristin Snoddon is leading a SSHRC-funded study with Indigenous communities on Indigenous deaf communities and ISLs that has been delayed due to the COVID-19 crisis.

${ }^{8}$ Kristin Snoddon and Kathryn Underwood, "Deaf time in the twenty-first century: Considering rights frameworks and the social relational model of Deaf childhood," Disability and Society 32, no. 9 (October 2009): 1405.
} 
not as a place of "cultural production for the Deaf community," or a place concerned with deaf futurity, but as a form of "special education" where poor student outcomes are seen as the fault of the student, not the educational system that has served them poorly. ${ }^{9}$ The contradictions of liberalism and settler colonialism are still with us, only incrementally transformed within, but holding up, the facades of Potemkin villages.

\footnotetext{
${ }^{9}$ Snoddon and Underwood, "Deaf time," 1404-05.
} 


\section{Bibliography}

\section{Unpublished Primary Sources}

Provincial Archives of Saskatchewan, Regina

Annual Reports, Bureau for Neglected Children/Bureau for Child Protection, 1912-1925, 1927-1932

Department of Education Correspondence Regarding Education of Deaf and Dumb and Blind, 1922-1929, 97G

James Calder Fonds. S-M2 GS 31 File 16 folders 1-4

Samuel Latta Fonds, S-M5 GS 34

Violet McNaughton Fonds, S-A1 E-17, Deaf, 1929-1952

William Martin Fonds, Collection S -M4 I 43

Provincial Archives of Manitoba, Winnipeg

Public Works Correspondence Incoming. Provincial Archives of Manitoba, Winnipeg. GS 0123 GR 1607

Premier's Correspondence, Thomas Greenway. EC 0016 GR 1662

Record of Pupils 1-374, 1889-1928. Provincial Archives of Manitoba, Winnipeg. A0061 GR 1635 Box 1, 3 books

Student Files - Admission Applications (Ab-Zm) 1890-1939. E 0197A Box 1 GR 4531

Unpublished Sessional Papers. G 8152 LA 0009 GR 174

Legislative Library of Manitoba, Winnipeg

Silent Echo vols. 10-22 (1900-1914) 
The Echo vols. 22-39 (1914-1939)

Deaf Heritage Room, Manitoba School for the Deaf, Winnipeg

Silent Echo vols 1-10 (1892-1900)

Annual Reports of the Manitoba Institute for the Deaf and Dumb, 1890-1903

University of Alberta Archives, Edmonton

R.J.D. Williams Papers 1989-71. Box 1 Correspondence

R.J.D. Williams Papers 1989-71. Box 2 Scrapbooks

Western Canadian Association of the Deaf Papers 2000-87

Alberta Legislative Library, Edmonton

Annual Reports of the Alberta Bureau of Neglected Children, 1906-1931

Department of Education Annual Reports, 1906-1909

\section{Published Primary Sources}

\section{Newspapers}

Brandon Mail

Brandon Daily Sun

Calgary Herald

Crossfield Chronicle

Manitoba Free Press

Moose Jaw Herald Times

Winnipeg Daily Times

Winnipeg Evening Tribune 


\section{Periodicals}

American Annals of the Deaf, 1888-1900.

\section{Government Publications}

Government of Alberta. Children's Protection Act. Chapter 12 of Statutes of Alberta.

Government of Saskatchewan. Children's Protection Act. June 12, 1908. Chapter 31 of Statutes of Saskatchewan.

Government of Saskatchewan. The Child Welfare Act. February 1, 1931. Chapter 231 of Revised Statutes of Saskatchewan.

\section{Other Publications}

Ballin, Albert. The Deaf Mute Howls. Washington, D.C.: Gallaudet University Press, 1998 [1931].

Clark, W.P. The Indian Sign Language, With Brief Explanatory Notes of the Gesture Taught Deaf-Mutes in Our Institutions for their Instruction, and a Description of Some of the Peculiar Laws, Customs, Myths, Superstitions, Ways of Living, Code of Peace and War Signals of Our Aborigines. Philadelphia: L.R. Hamersly, 1885. Hathitrust.

Desloges, Pierre. Observations d'un sourd et muèt, sur un cours elémentaire d'education des sourds et muèts (Paris: B. Morin, 1779). Hathitrust.

H.H. "A Future for the Deaf and Dumb in the Canadian North-West." London, 1884. Peel's Prairie Provinces, (http://peel.library.ualberta.ca/bibliography/1240.html).

McCully Brown, Molly. The Virginia State Colony for Epileptics and Feebleminded: Poems. New York: Persea, 2017.

McGann, J.B. "Sixth Annual Report of the Upper Canada Institution for the Deaf and Dumb and Blind for the Year 1864." Toronto Reference Library, FILM F CIHM 37385 . 
Tompkins, William. Universal Sign Language of the Plains Indians of North America: Together With a Simplified Method of Study, a List of Words in Most General Use, a Codification of Pictographic Symbols of the Sioux and Ojibway, a Dictionary of Synonyms, a History of Sign Language, Chapters on Smoke Signaling, Use of Idioms, etc., and Other Important Co-Related Matter. San Diego: Self-published, 1929. Hathitrust.

Weber, Joanne. The Deaf House. Saskatoon: Thistledown Press, 2013.

\section{$\underline{\text { Secondary Sources }}$}

Adams, Christopher. Politics in Manitoba: Parties, Leaders, and Voters. Winnipeg: University of Manitoba Press, 2008.

Alcorn, Kerry. Border Crossings: U.S. Culture and Education in Saskatchewan, 19051937. Montreal and Kingston: McGill-Queen's University Press, 2013.

Artibise, Alan F.J. Winnipeg: A Social History of Urban Growth, 1874-1914. Montreal and Kingston: McGill-Queen's University Press, 1975.

Atkinson, Dorothy, and Jan Walmsley. "History from the Inside: Towards an Inclusive History of Intellectual History." Scandinavian Journal of Disability Research 12, no. 4 (2010): 273-286.

Axelrod, Paul. The Promise of Schooling: Education in Canada, 1800-1914. Toronto: University of Toronto Press, 1997.

Banoub, David. "The Patronage Effect: Civil Service Reforms, Job-Seeking, and State Formation in Victorian Canada." PhD diss., Carleton University, 2013.

Bangarth, Stephanie, and Jennifer Tunnicliffe. "Writing Rights into the 'New' Political History." The Canadian Historical Review, 100, no. 4 (December 2019): 638-653.

Barnett, Michael. Empire of Humanity: A History of Humanitarianism. Ithaca: Cornell University Press, 2011.

Barnhart, Gordon L. "Walter Scott." In Saskatchewan Premiers of the Twentieth Century, edited by Gordon L. Barnhart, 1-38. Regina: University of Regina Press, 2004. 
. "Frederick Haultain, 1897-1905." In Saskatchewan Premiers of the Twentieth Century. Edited by Gordon L. Barnhart, iv-xiii. Regina: University of Regina Press, 2004.

Barron, Sandy R. “'The Absolute Indifference of the Majority': The Western Canadian Association of the Deaf and the Establishment of Deaf Education in Saskatchewan, 1923-1931." The Canadian Historical Review 102, no.1 (2021): forthcoming.

. "'The World is Wide Enough for Us Both': The Manitoba School for the Deaf at the Onset of the Oralist Age, 1889-1920." The Canadian Journal of Disability Studies 6, no. 1 (2017): 63-84.

Bauman, H-Dirksen L. "Audism: Exploring the Dynamics of Oppression." Journal of Deaf Studies and Deaf Education 9, no. 2 (Spring 2004): 239-246.

Baynton, Douglas. Defectives in the Land: Disability and Immigration in the Age of Eugenics. Chicago: University of Chicago Press, 2016. . "Disability and the Justification of Inequality in American History." In The New Disability History: American Perspectives, edited by Paul Longmore and Lauri Umanski, 33-57. New York: New York University Press, 2001.

. Forbidden Signs: American Culture and the Campaign Against Sign Language. Chicago: University of Chicago Press, 1996.

Bender, Thomas. A Nation Among Nations: America's Place in World History. New York: Hill and Wang, 2006.

Berghs, Maria. "The New Humanitarianism: Neoliberalism, Poverty, and the Creation of Disability." In Disability, Human Rights, and the Limits of Humanitarianism, edited by Michael Gill and Cathy J. Schlund-Vials, 27-43. London: Routledge, 2014.

Bilson, Beth. "The Prairie Face of Labour.” In Perspectives of Saskatchewan, edited by Jene Porter, 197-214. Winnipeg: University of Manitoba Press, 2009.

Binnema, Theodore. “Allegiances and Interests: Niitsitapi (Blackfoot) Trade, Diplomacy, and Warfare, 1806-1831." The Western Historical Quarterly 37, no. 3 (Autumn 2006): 327-349. 
. Common and Contested Ground: A Human and Environmental

History of the Northwestern Plains. Norman: OK: University of Oklahoma Press, 2001.

Breen, Jonathon S. “On-Demand American Sign Language Interpreting Services: Social Policy Development in the Yukon.” Sign Language Studies 15, no. 3 (2015): 348361.

Brennan, J. William. "Charles A. Dunning.” In Saskatchewan Premiers of the Twentieth Century, edited by Gordon L. Barnhart, 69-87. Regina: University of Regina Press, 2004.

. "The ‘Autonomy Question' and Alberta and Saskatchewan.” In The Prairie West: Historical Readings. Edited by R. Douglas Francis and Howard Palmer, 378-396. Edmonton, Pica Press, 1992.

Brown, Robert Craig. Robert Laird Borden, 1854-1914. Toronto: MacMillan, 1975.

Brownlee, Robin Jarvis. "A Persistent Antagonism: First Nations and the Liberal Order." In Liberalism and Hegemony: Debating the Canadian Liberal Revolution, edited by Jean-Francois Constant and Michel Ducharme, 298-321. Toronto: University of Toronto Press, 2009.

Brunsma, David, Keri E. Iyall Smith, and Brian K. Gran. Handbook of Sociology and Human Rights. Boulder: Paradigm, 2013.

Bryden, P.E. "Foxes, Hedgehogs, and the Changing Shape of English-Canadian Political History." The Canadian Historical Review 100, no. 4 (December 2019): 588-601.

Buchanan, Robert M. Illusions of Equality: Deaf Americans in School and Factory, 1850-1950. Washington, D.C.: Gallaudet University Press, 1999.

Burch, Susan and Michael Rembis. "Re-Membering the Past: Reflections on Disability Histories." In Disability Histories, edited by Susan Burch and Michael Rembis, 113. Urbana: University of Illinois Press, 2014.

Burch, Susan. Signs of Resistance: American Deaf Cultural History, 1900 to World War II. New York: NYU Press, 2002. 
Burghart, Madeline. Broken: Institutions, Families, and the Construction of Intellectual Disability. Montreal and Kingston: McGill-Queen's University Press, 2019. . "Institutional Survivorship: Abandonment and the 'Machinery of the Establishment.' Canadian Journal of Disability Studies 6, no. 3 (2017), 119148.

Burke, Stacie. Building Resistance: Children, Tuberculosis, and the Toronto Sanitarium. Montreal and Kingston: McGill-Queen's University Press, 2018.

Bynum, Bill. "Maternal Impressions.” The Lancet 359 (March 9, 2002): 898.

Capurri, Valentina. Not Good Enough For Canada: Canadian Public Discourse Around Issues of Inadmissibility for Potential Immigrants with Diseases and/or Disabilities. (Toronto: University of Toronto Press, 2020).

Carbin, Clifton. Deaf Heritage in Canada: A Distinctive, Diverse, and Enduring Culture. Toronto: McGraw-Hill Ryerson, 1996.

Carlson, Licia. "Docile Bodies, Docile Minds: Foucauldian Reflections on Mental Retardation." In Foucault and the Government of Disability, edited by Shelley Tremain, 133-152. Ann Arbor: University of Michigan Press, 2005.

Carter, Sarah. Imperial Plots: Women, Land, and the Spadework of British Imperialism on the Canadian Prairies. Winnipeg: University of Manitoba Press, 2016.

Chadha, Ena. “'Mentally Defectives' Not Welcome: Mental Disability in Canadian ImmigrationLaw, 1856-1927." Disability Studies Quarterly 28, no. 1 (2008).

Clarke, Nic. "Opening Closed Doors and Breaching High Walls: Some Approaches for Studying Intellectual Disability in Canadian History. Histoire Sociale/Social History 39 (2006), 467-485.

Clement, Dominique. Human Rights in Canada: A History. Waterloo: University of Waterloo Press, 2016.

. "Human Rights in Canadian Domestic and Foreign Politics: From 'Niggardly Acceptance' to Enthusiastic Embrace." Human Rights Quarterly 34 (2012), 751-778. 
Colpitts, George. Pemmican Empire: Food, Trade, and the Last Bison Hunts on the North American Plains, 1780-1882. New York: Cambridge University Press, 2015 .

Comacchio, Cynthia. The Infinite Bonds of Family: Domesticity in Canada, 1850-1940. Toronto: University of Toronto Press, 1999. . Nations Are Built of Babies: Saving Ontario's Mothers and Children. Montreal and Kingston: McGill-Queen's University Press, 1993.

Commend, Susanne. "Au secours des petits infirmes: Les enfants handicapés physiques au Quebec entre charité et exclusion, 1920-1990," PhD thesis, Université de Montréal, 2018.

Corrigan, Philip, and Derek Sayer. The Great Arch: English State Formation as Cultural Revolution. Oxford: Basil Blackwell, 1985.

Coulter, Rebecca. "'Not to Punish but to Reform': Juvenile Delinquency and the Children's Protection Act in Alberta, 1909-1929." In Social Welfare Policy in Canada: Historical Readings, eds. Raymond B. Blake and Jeff Keshen. Toronto: Copp Clark, 1995.

Curtis, Bruce. Ruling by Schooling Quebec: Conquest to Liberal Governmentality: A Historical Sociology. Toronto: University of Toronto Press, 2012.

. The Politics of Population: State Formation, Statistics, and the Census of Canada, 1840-1875. Toronto: University of Toronto Press, 2002.

. "Liberalisms, Social Theory, and Historical Analysis." In Liberalism and Hegemony: Debating the Canadian Liberal Revolution Edited by Jean-Francois Constant and Michel Ducharme,176-200. Toronto: University of Toronto Press, 2009.

Daschuk, James. Clearing the Plains: Disease, Politics of Starvation, and the Loss of Aboriginal Life. Regina: University of Regina Press, 2014.

Davis, Jeffrey. "The Linguistic Vitality of American Indian Sign Language: Endangered, Yet Not Vanished." Sign Language Studies 16, no. 4 (Summer 2016): 535-562. 
. "Discourse Features of American Indian Sign Language (AISL)." In

Discourse in Signed Languages, edited by Cynthia B. Roy, 179-218.

Washington, D.C.: Gallaudet University Press, 2011.

. Hand Talk: Sign Language Among American Indian Nations. New York:

Cambridge University Press, 2010.

. "North American Indian Signed Language Varieties: A Comparative Historical Linguistic Assessment." In Sign Languages in Contact, ed. David Quinto-Pozos, 85-122. Washington, D.C.: Gallaudet University Press, 2007.

Davis, Lennard. Enforcing Normalcy: Disability, Deafness, and the Body. Chicago: Verso, 1995.

De Clerck, Goedele A. M. Deaf Epistemologies, Identity, and Learning: A Comparative Perspective. Washington, D.C.: Gallaudet University Press, 2016.

De Meulder, Maartje, and Joseph J. Murray. "Buttering Their Bread on Both Sides? The Recognition of Sign Languages and the Aspirations of Deaf Communities." Language Problems and Language Planning 41, no. 2 (2017), 136-158.

De Veirman, Sofie. "Deaf and Disabled? (Un)Employment of Deaf People in Belgium: A Comparison of Eighteenth-Century and Nineteenth-Century Cohorts." Disability and Society 30, no. 3 (2015): 460-474.

Dolmage, Jay Timothy. Academic Ableism: Disability and Higher Education. Ann Arbor: University of Michigan Press, 2017.

Ducharme, Michel. The Idea of Liberty: In Canada During the Age of Atlantic Revolutions, 1776-1838. Translated by Peter Feldstein. Montreal and Kingston: McGill-Queen's University Press, 2014.

Durkheim, Emile. The Elementary Forms of the Religious Life. Translated by Joseph Ward Swain. London: George Allen and Unwin, 1964 [1915].

Dyck, Erika and Alex Deighton. Managing Madness: Weyburn Mental Hospital and the Transformation of Psychiatric Care in Canada. Winnipeg: University of Manitoba Press, 2017. 
Dyck, Erika. Facing Eugenics: Reproduction, Sterilization, and the Politics of Choice. Toronto: University of Toronto Press, 2013.

Edwards, R.A.R. Words Made Flesh: Nineteenth Century Deaf Education and the Growth of Deaf Culture. New York: NYU Press, 2012. . "Teaching Deaf History," Radical History Review 94 (Winter 2006): 183-190.

Ellis, Jason, and Kate Rousmaniere. "Professor Bailyn, Meet Professor Baynton: The 'New Disability History of Education'." History of Education Quarterly 60, no.3 (August 2020): 285-294.

Ellis, Jason. A Class by Themselves? The Origins of Special Education in Toronto and Beyond. Toronto: University of Toronto Press, 2019. . "Early Educational Exclusion: 'Idiotic' and 'Imbecilic' Children, Their Families, and the Toronto Public School System, 1914-1950." The Canadian Historical Review 98, no. 3 (September 2017), 483-504.

. "'All Methods and Wedded to None': The Deaf Education Methods Debate and Progressive Education Reform in Toronto, Canada, 1922-1945," Paedagogica Historica 50, no. 3 (2014).

Erlmann, Veit. Reason and Resonance: A History of Modern Aurality. Cambridge, MIT Press, 2010.

Esmail, Jennifer. Reading Victorian Deafness: Signs and Sounds in Victorian Literature and Culture. Athens, OH: University of Ohio Press, 2013.

Eyford, Ryan. White Settler Reserve: New Iceland and the Colonization of the Canadian West. Vancouver: UBC Press, 2016.

Fahrni, Magda. Household Politics: Montreal Families and Postwar Reconstruction. Toronto: University of Toronto Press, 2005.

Fecteau, Jean-Marie. The Pauper's Freedom: Crime and Poverty in Nineteenth-Century Quebec. Translated by Peter Feldstein. Montreal and Kingston: McGill-Queen's University Press, 2017 [2004]). 
Finkel, Alvin. The Social Credit Phenomenon in Alberta. Toronto: University of Toronto Press, 1989.

Foucault, Michel. The History of Sexuality: An Introduction. Volume One. New York: Pantheon Books, 1978.

Friedner, Michelle. "Understanding and Not-Understanding: What Do Epistemologies and Ontologies Do in Deaf Worlds?" Sign Language Studies 16, no. 2 (Winter 2016): 184-203.

Friesen, Gerald. "The Manitoba Political Tradition.” In Manitoba Politics and Government: Issues, Institutions, Traditions, edited by Paul G. Thomas and Curtis Brown, 21-42. Winnipeg: University of Manitoba Press, 2010.

Fye, Bruce. Caring For the Heart: The Mayo Clinic and the Rise of Specialization. New York: Oxford University Press, 2015.

Galer, Dustin. Working Towards Equity: Disability Rights Activism and Employment. Toronto: University of Toronto Press, 2018.

Gidney, R.D. and W.P.J. Millar. How Schools Worked: Public Education in English Canada, 1900-1940. Montreal and Kingston: McGill-Queen's University Press, 2012. . Inventing Secondary Education: The Rise of High School in Nineteenth-Century Ontario. Montreal and Kingston: McGill-Queen's University Press, 1990.

Gleason, Mona. Small Matters: Canadian Children in Sickness and Health. Montreal and Kingston: McGill-Queen's University Press, 2013. . Normalizing the Ideal: Psychology, Schooling, and the Family in Postwar Canada. Toronto: University of Toronto Press, 1999.

Gleeson, Brendan. Geographies of Disability. New York: Routledge, 1999.

Goffman, Erving. Stigma: Notes on the Management of Spoiled Identity. New York: Simon and Schuster, 1963. 
Goodey, C.F. A History of Intelligence and 'Intellectual Disability': The Shaping of Psychology in Early Modern Europe. Farnham: Ashgate, 2011.

Greer, Allan, and Ian Radforth. "Introduction.” In Colonial Leviathan: State Formation in Mid-Nineteenth-Century Canada, edited by Allan Greer and Ian Radforth, 3-16. Toronto: University of Toronto Press, 1992.

Griffith, Jane. Words Have a Past: The English Language, Colonialism, and the Newspapers of Indian Boarding Schools. Toronto: University of Toronto Press, 2019.

Grittner, Colin. "Greater Expectations: Politics, the New Political History, and the Structuring of (Canadian) Society." The Canadian Historical Review 100, no. 4 (December 2019): 602-619.

Groce, Nora Ellen. Everyone Here Spoke Sign Language: Hereditary Deafness on Martha's Vineyard. Cambridge, MA: Harvard University Press, 1985.

Guest, Dennis. The Emergence of Social Security in Canada. Second Edition. Vancouver: UBC Press, 1990.

Hall, David. "Arthur L. Sifton.” In Alberta Premiers of the Twentieth Century, edited by Bradford J. Rennie, 19-42. Regina: University of Regina Press, 2004.

Hall, Wyatte C., Levin, Leonard L., and Anderson, Melissa L. "Language Deprivation Syndrome: A Possible Neurodevelopmental Disorder with Sociological Origins." Soc Psychiatry Psychiatr Epidemiol 52, no. 6 (June 2017), 761-776.

Hampton, Jameel. "Discovering Disability: The General Classes of Disabled People and the Classic Welfare State, 1948-1964." Historian 75, no. 1 (2013): 69-93.

Hamraie, Aimi. Building Access: Universal Design and the Politics of Disability. Minneapolis: University of Minnesota Press, 2017.

Hartig, Rachel M. Crossing the Divide: Representations of Deafness in Biography. Washington, D.C.: Gallaudet University Press, 2016.

Hartz, Louis. The Liberal Tradition in America: An Interpretation of Liberal Thought Since the Revolution. San Diego: Harcourt and Brace, 1955. 
Heaman, E.A. Tax, Order, and Good Government: A New Political History of Canada, 1867-1917. Montreal and Kingston: McGill-Queen's University Press, 2017. . A Short History of the State in Canada. Toronto: University of Toronto Press, 2015.

. "Rights Talk and the Liberal Order Framework." In Liberalism and Hegemony: Debating the Canadian Liberal Revolution. Edited by Jean-Francois Constant and Michel Ducharme, 147-175. Toronto: University of Toronto Press, 2009.

Henner, Jon, Catherine L. Caldwell-Harris, Rama Novogrdsky, and Robert Hoffmeister, "American Sign Language Syntax and Analogical Reasoning Skills are Influenced by Early Acquisition and Age of Entry to Signing Schools for the Deaf," Frontiers in Psychology (2016).

Higgs, Robert. Crisis and Leviathan: Critical Episodes in the Growth of American Government. New York: Oxford University Press, 1987.

Hogue, Michel. Metis and the Medicine Line: Creating a Border and Dividing a People. Regina: University of Regina Press, 2015.

Horodyski, Mary. “'A Very Serious Matter': The Manitoba Government's Institution for People with Intellectual Disability." Prairie History, no. 1 (Winter 2020).

Houston, Susan and Alison Prentice. Schooling and Scholars in Nineteenth-Century Ontario. Toronto: University of Toronto Press, 1988.

Howard-Hassman, Rhoda E. "Liberalism, Social Democracy, and Human Rights." In Debating Rights Inflation in Canada: A Sociology of Human Rights, edited by Dominique Clement, 121-132. Waterloo: Wilfrid Laurier University Press, 2018.

Iozzo-Duval, Alessandra. "The Education of 'Good' and 'Useful' Citizens: Work, Disability, and d/Deaf Citizenship at the Ontario Institution for the Education of the Deaf, 1892-1902." In Untold Stories: A Canadian Disability History Reader, edited by Nancy Hansen, Roy Hanes, and Diane Driedger, 66-90. Toronto: Canadian Scholar's Press, 2018.

Ishiguro, Laura. Nothing to Write Home About: British Family Correspondence and the Settler Colonial Everyday in British Columbia. Vancouver: UBS Press, 2019. 
Johnson, Robert E., Scott K. Liddell, and Carol J. Erting. Unlocking the Curriculum: Principles for Achieving Access in Deaf Education. Gallaudet Research Institute Working Paper 89-3. Washington, D.C.: Department of Linguistics and Interpreting and the Gallaudet Research Institute, 1989.

Johnston, Richard. The Canadian Party System: An Analytic History. Vancouver: UBC Press, 2017.

Jones, Esyllt W. Influenza 1918: Disease, Death, and Struggle in Winnipeg. Toronto: University of Toronto Press, 2007.

Kafer, Alison. Feminist, Queer, Crip. Bloomington: University of Indiana Press, 2013.

Kaler, Amy. Baby Trouble in the Last Best West: Making New People in Alberta, 19051939. Toronto: University of Toronto Press, 2017.

Komesaroff, Linda. Disabling Pedagogy: Power, Politics, and Deaf Education. Washington, D.C.: Gallaudet University Press, 2008.

Korneski, Kurt. Race, Nation, and Reform Ideology in Winnipeg, 1880s-1920s. Madison: Fairleigh Dickinson University Press, 2015.

Kramer, Reinhold and Tom Mitchell. Walk Towards the Gallows: The Tragedy of Hilda Blake, Hanged 1899. Toronto: University of Toronto Press, 2007 [2002]).

Kusters, Annelies, Maartje Muelder, and Dai O'Brien. "Innovations in Deaf Studies: Critically Mapping the Field." In Innovations in Deaf Studies: The Role of Deaf Scholars, edited by Annelies Kusters, Maartje Muelder, and Dai O'Brien, 1-38. Oxford: Oxford University Press, 2016.

Kusters, Annelies. "Deaf Gain and Shared Signing Communities." In Deaf Gain: Raising the Stakes for Human Diversity, edited by H-Dirksen L. Bauman and Joseph J. Murray, 285-305. Minneapolis: University of University Press, 2014.

. "Deaf Utopias? Reviewing the Sociocultural Literature on the World's 'Martha's Vineyard Situations." Journal of Deaf Studies and Deaf Education 15, no. 1 (Winter 2010), 3-16. 
Kyba, Patrick. "J.T.M. Anderson." In Saskatchewan Premiers of the Twentieth Century, edited by Gordon L. Barnhart, 109-138. Regina: University of Regina Press, 2004.

Ladd, Paddy. Understanding Deaf Culture: In Search of Deafhood. Bristol: Channelview Publications, 2003.

Lane, Harlan. When the Mind Hears: A History of the Deaf. New York: Vintage, 1984. . The Wild Boy of Aveyron. Cambridge: Harvard University Press, 1976.

Lang, Harry G. "Genesis of a Community: The American Deaf Experience in the Seventeenth and Eighteenth Centuries." In The Deaf History Reader, edited by John Vickrey Van Cleve, 1-23. Washington, D.C.: Gallaudet University Press, 2007.

Laycock, David. Populism and Democratic Thought in the Canadian Prairies, 19101945. Toronto: University of Toronto Press, 1990.

Linton, Simi. "Disability Studies/Not Disability Studies." Disability and Society 13, no. 4 (1998), 525-539.

Loewen, Royden and Gerald Friesen. Immigrants in Prairie Cities: Ethnic Diversity in Twentieth-Century Canada. Toronto: University of Toronto Press, 2009.

Loewen, Royden. "Beyond the Monolith of Modernity: New Trends in Immigrant and Ethnic Rural History.” Agricultural History 81, no. 2 (Spring 2007), 204-227.

Loo, Tina. Moved by the State: Forced Relocation and Making a Good Life in Postwar Canada. Vancouver: UBC Press, 2019.

Lupul, Manoly R. The Roman Catholic Church and the North-West School Question. Toronto: University of Toronto Press, 1974.

Lux, Maureen. Separate Beds: A History of Indian Hospitals in Canada, 1920s-1980s. Toronto: University of Toronto Press, 2016.

MacDougall, J.C. "Access to Justice for Deaf Inuit in Nunavut: The Role of 'Inuit Sign Language.." Canadian Psychology 42, no. 1 (2001): 61-73.

MacPherson, C.B. Democracy in Alberta: Social Credit and the Party System. Toronto: 
University of Toronto Press, 2013 [1953]).

Malacrida, Claudia. A Special Hell: Institutional Life in Alberta's Eugenic Years.

Toronto: University of Toronto Press, 2015.

Malzkuhn, Melissa. "Compromising for Agency: The Role of the NAD during the American Eugenics Movement, 1880-1940." In In Our Own Hands: Essays in Deaf History 1780- 1970, edited by Brian H Greenwald and Joseph J. Murray, 171-192. Washington, D.C.: Gallaudet University Press, 2016.

Mann, Michael. The Sources of Social Power Volume 4: Globalizations, 1945-2011. New York: Cambridge University Press, 2013.

. The Sources of Social Power Volume 3: Global Empires and Revolution, 1890- 1945. New York: Cambridge University Press, 2012.

. The Sources of Social Power Volume 2: The Rise of Classes and NationStates, 1760-1914. New York: Cambridge University Press, 2012 [1993]).

. The Sources of Social Power Volume 1: A History of Power from the Beginning to AD 1760. New York: Cambridge University Press, 2012 [1986]).

Mantin, Mike. ''His Whole Nature Requires Development': Education, School Life and Deafness in Wales, 1850-1914. Social History of Medicine 30, no.4 (2017): 727747.

Marshall, Dominique. The Social Origins of the Welfare State: Quebec Families, Compulsory Education, and Family Allowances, 1940-1955. Translated by Nicola Doone Danby. Waterloo: University of Waterloo Press, 2006 [1998]).

Maxwell, Krista. "Settler-Humanitarianism: Healing the Indigenous Child-Victim." Comparative Studies in Society and History 59, no. 4 (2017): 974-1007.

McCallum, Mary Jane Logan. Indigenous Women, Work, and History: 1940-1980. Winnipeg: University of Manitoba Press, 2014.

McCoy, Ted. Hard Time: Reforming the Penitentiary in Nineteenth-Century Canada. Edmonton: Athabasca University Press, 2012.

McKay, Ian. Reasoning Otherwise: Leftists and the People's Enlightenment in Canada, 1890-1920. Toronto: Between the Lines, 2008. 
. "The Liberal Order Framework: A Prospectus for a Reconnaissance of Canadian History." The Canadian Historical Review 81, no. 4 (December 2000): 617-645.

McLaren, Angus. Our Own Master Race: Eugenics in Canada, 1885-1945. Toronto: McClelland and Stewart, 1990.

McManus, Sheila. The Line Which Separates: Race, Gender, and the Making of the Alberta-Montana Borderlands. Lincoln, University of Nebraska Press, 2005.

Mills, Charles W. The Racial Contract. Ithaca: Cornell University Press, 1997.

Miron, Janet. Prisons, Asylums, and the Public: Institutional Visiting in the Nineteenth Century. Toronto: University of Toronto Press, 2011.

Morton, Suzanne. Wisdom, Justice, and Charity: Canadian Social Welfare Through the Life of Jane B. Wisdom, 1884-1975. Toronto: University of Toronto Press, 2014.

Morton, W.L. Manitoba: A History. Toronto: University of Toronto Press, 1957. . The Progressive Party in Canada. Toronto: University of Toronto Press, 1950.

Murray, Joseph J. “'Enlightened Selfishness: Gallaudet College and Deaf Citizenship in the United States, 1864-1904." In In Our Own Hands: Essays in Deaf History 1780-1970, edited by Brian H. Greenwald and Joseph J. Murray, 18-39.

Washington, D.C.: Gallaudet University Press, 2016.

. "'One Touch of Nature Makes the Whole World Kin': The Transnational Lives of Deaf Americans, 1870-1924." PhD diss., University of Iowa, 2007.

. "Coequality and Transnational Studies: Understanding Deaf Lives." In Open Your Eyes: Deaf Studies Talking, edited by H-Dirksen L. Bauman, 100-110. Minneapolis: University of Minnesota Press, 2002.

Murray, Joseph J., Wyatt C. Hall, and Kristin Snoddon. "Education and the Health of Children with Hearing Loss: The Necessity of Signed Languages" Bulletin of the World Health Organization 97, no. 10 (October 2019): 711-716. 
Myers, Tamara Gene. Youth Squad: Policing Children in the Twentieth Century. Montreal and Kingston: McGill-Queen's University Press, 2019.

Nicolas, Jane. Canadian Carnival Freaks and the Extraordinary Body, 1900-1970s. Toronto: University of Toronto Press, 2018.

Nielson, Carmen. Private Women and the Public Good: Charity and State Formation in Hamilton, Ontario, 1846-93. Vancouver: UBC Press, 2014.

Nielson, Kim. "Property, Disability, and the Making of the Incompetent Citizen in the United States, 1860s-1940s." In Disability Histories, edited by Susan Burch and Michael Rembis (Urbana: University of Illinois Press, 2014), 308-320.

Oliver, Michael. "Activism and the Academy: Losing the Ideological and Material Battles.” Disability and Society, 34, no.7-8 (2019): 1028-1033.

Panitch, Leo. The Canadian State: Political Economy and Political Power. Toronto: University of Toronto Press, 1977.

Padden, Carol, and Tom Humphries. Inside Deaf Culture. Cambridge, MA: Harvard University Press, 2006.

. Deaf in America: Voices From a Culture.

Cambridge, MA: Harvard University Press, 1988.

Pasolli, Lisa. "Recent Works in Twentieth-Century Women's, Gender, and "The New Political" History. The Canadian Historical Review 101, no.3 (September 2020): 450-459.

Pateman, Carole. The Sexual Contract. Stanford: Stanford University Press, 1988.

Pearce, Joanna. "To Give Light Where He Made All Dark": Educating the Blind About the Natural World and God in Nineteenth-Century America. History of Education Quarterly 60, no. 3 (August 2020): 295-323.

. "Not For Alms but For Help: Fund-Raising and Free Education for the Blind." The Journal of the Canadian Historical Association 23, no. 1 (2012): 131156. 
Perry, Adele. "Starting With Water: Canada, History, and Colonialism at 2019." Journal of the Canadian Historical Association 30, no.1 (2020): 6-31. . Colonial Relations: The Douglas-Connelly Family and the NineteenthCentury Imperial World. Cambridge: Cambridge University Press, 2015.

Pitsula, James. Keeping Canada British: The Ku Klux Klan in 1920s Saskatchewan. Vancouver: UBC Press, 2013.

Polanyi, Karl. The Great Transformation: The Political and Economic Origins of Our Time. Boston: Beacon Press, 2001 [1944].

Prince, Michael J. "Placing Universality in Canadian Social Policy and Politics." In Universality and Social Policy in Canada, edited by Daniel Beland, Gregory P. Marchildon, and Michael J. Prince, 17-30. Toronto: University of Toronto Press, 2019.

Quinto-Pozos, David. "Sign Languages in Contact." In Sociolinguistics and Deaf Communities, edited by Adam C. Schembri and Ceil Lucas, 29-60. Cambridge: Cambridge University Press, 2015.

Reaume, Geoffrey. "Posthumous Exploitation? The Ethics of Researching, Writing, and Being Accountable as a Disability Historian." In Untold Stories: A Canadian Disability History Reader, edited by Nancy Hansen, Roy Hanes, and Diane Driedger, 26-39. Toronto: Canadian Scholar's Press, 2018.

. "The Place of Mad People and Disabled People in Canadian Historiography: Surveys, Biographies, and Specialized Fields." Journal of the Canadian Historical Association 28, no.1 (2017), 277-316.

. Remembrance of Patients Past: Patient Life at the Toronto Hospital for the Insane, 1870-1940. Toronto: University of Toronto Press, 2009 [2000].

Regehr, Ted. "William M. Martin." In Saskatchewan Premiers of the Twentieth Century, edited by Gordon L. Barnhart. Regina, University of Regina Press, 2004.

Reis, Michael. "A Tale of Two Schools: The Indiana Institution and the Evansville Day School, 1879-1912." In The Deaf History Reader, edited by John Vickrey Van Cleve, 85-115. Washington, D.C.: Gallaudet University Press, 2007. 
Rennie, Bradford J. "Introduction." In Alberta Premiers of the Twentieth Century. Edited by Bradford J. Rennie. Regina: University of Regina Press, 2004.

Rinaldi, Jen and Jay Dolmage. “'Of Dark Type and Poor Physique': Law, Immigration Restriction, and Disability in Canada, 1900-1930." In Disabling Barriers: Social Movements, Disability History, and the Law, edited by Ravi Malholtra and Benjamin Isitt, 98-122. Vancouver: UBC Press, 2017.

Robinson, Octavian E., and Jonathan Henner. "The Personal is Political in The Deaf Mute Howls: Deaf Epistemology Seeks Disability Justice." Disability and Society 32, no. 9 (2017): 1416-1436.

Robinson, Octavian. "In Pursuit of Citizenship: Campaigns Against Peddling in Deaf America, 1880s-1950s." In In Our Own Hands: Essays in Deaf History 17801970, edited by Brian H. Greenwald and Joseph J. Murray, 127-148. Washington, D.C.: Gallaudet University Press, 2016.

. "Seeking that Which Might Constitute Our Common Humanity: Deaf Studies, Social Justice, and the Liberal Arts." Sign Language Studies 17, no.1 (Fall 2016): 89-95.

Rollings-Magnusson, Sandra. Heavy Burdens on Small Shoulders: The Labour of Pioneer Children on the Canadian Prairies. Edmonton: University of Alberta Press, 2009.

Roome, Patricia. "Alexander C. Rutherford." In Alberta's Premiers of the Twentieth Century, ed. Bradford J. Rennie. Regina, University of Regina Press, 2004.

Ruiz-Williams, Elena, Meredith Burke, Vee Yee Chong, and Noppawan Chainarong. "'My Deaf is not Your Deaf": Realizing Intersectional Realities at Gallaudet University." In It's a Small World: International Deaf Spaces and Encounters, eds. Michelle Friedner and Annelies Kusters. Washington, D.C.: Gallaudet University Press, 2015.

Sacks, Oliver. Seeing Voices: A Journey into the World of the Deaf. Oakland: University of California Press, 1989.

Sandwell, Ruth. Canada's Rural Majority: Households, Environments, and Economies, 1870-1940. (Toronto: University of Toronto Press, 2016).

Schweik, Susan M. The Ugly Laws: Disability in Public. New York: New York University Press, 2009.

Sherly-Appel, Clara and John D. Bonvillian. "Manual Signs and Gestures of the Inuit of Baffin Island: Observations During the Three Voyages Led by Martin Frobisher." In Deaf Gain: Raising the Stakes for Human Diversity, edited by H-Dirksen L. 
Bauman and Joseph J. Murray, 159-181. Minneapolis: University of Minnesota Press, 2014.

Shore, Marlene. The Science of Social Redemption: McGill, the Chicago School, and the Origins of Social Research in Canada. Toronto: University of Toronto Press, 1987.

Skocpol, Theda. Protecting Soldiers and Mothers: The Political Origins of Social Policy in the United States. Cambridge, Mass.: The Belknap Press of Harvard University Press, 1992.

Simeon, Richard. Federal-Provincial Diplomacy: The Making of Recent Policy in Canada. Toronto: University of Toronto Press, 1972.

Simplican, Stacy Clifford. The Capacity Contract: Intellectual Disability and the Question of Citizenship. Minneapolis: University of Minnesota Press, 2015.

Simpson, Murray K. "Othering Intellectual Disability: Two Models of Classification from the $19^{\text {th }}$ Century." Theory and Psychology 22, no. 5 (October 2012), 541555.

Smith, David. "James G. Gardiner.” In Saskatchewan Premiers of the Twentieth Century, edited by Gordon L. Barnhart, 89-108. Regina: University of Regina Press, 2004.

. Prairie Liberalism: The Liberal Party in Saskatchewan 1905-1971.

Toronto: University of Toronto Press, 1975.

Snoddon, Kristin, and Kathryn Underwood. "Deaf-time in the Twenty-First Century: Considering Rights Frameworks and the Social Relational Model of Deaf Childhood." Disability and Society 32, no. 9 (October 2017): 1400-1415.

Snyder, Sharon and David Mitchell. Cultural Locations of Disability. (Chicago: University of Chicago Press, 2006).

Spagnuolo, Natalie. "Defining Dependency, Constructing Curability: The Deportation of 'Feeble-Minded' Patients from the Toronto Asylum, 1920-1925.' Histoire Sociale/Social History 49 (May 2016), 125-154.

Stone, Christopher, and Bencie Woll. "Dumb O Jemmy and Others: Deaf People, Interpreters, and the London Courts in the Eighteenth and Nineteenth Centuries." Sign Language Studies 8, no. 2 (Spring 2018): 226-240.

Strong-Boag, Veronica. Fostering Nation? Canada Confronts its History of Childhood 
Disadvantage. Waterloo: University of Waterloo Press, 2011.

. "'Forgotten People of all the Forgotten': Children with Disabilities in Canada from the Nineteenth Century to the New Millenium." In Lost Kids: Vulnerable Children and Youth in Twentieth-Century Canada and the United States, edited by Mona Gleason, Tamara Myers, Leslie Paris, and Veronica Strong-Boag. Vancouver: UBC Press, 2010.

Supalla, Ted, and Patricia Clark. Sign Language Archaeology: Understanding the Historical Roots of American Sign Language (Washington, D.C.: Gallaudet University Press, 2015).

Sutton-Spence, Rachel. "The Role of Sign Language Narratives in Developing Identity for Deaf Children." Journal of Folklore Research 47, no.3 (2010): 265-305.

Thomas, Lewis G. The Liberal Party in Alberta: A History of Politics in the Province of Alberta 1905-1921. Toronto: University of Toronto Press, 1959.

Thomas, Lewis H. The Struggle for Responsible Government in the North-West Territories, 1870-1897. Toronto: University of Toronto Press, 1956.

Tillotson, Shirley. Give and Take: The Citizen-Taxpayer and the Rise of Canadian Democracy. Vancouver: UBC Press, 2017. . Contributing Citizens: Modern Charitable Fundraising and the Making of the Welfare State, 1920-1966. Vancouver: UBC Press, 2008.

Titchkosky, Tanya. Reading and Writing Disability Differently: The Textured Life of Embodiment. Toronto: University of Toronto Press, 2007.

Tough, David. The Terrific Engine: Income Taxation and the Modernization of the Canadian Political Imaginary. Vancouver: UBC Press, 2018.

Tremain, Shelley. "On the Government of Disability." Social Theory and Practice 27, no. 4 (October 2001): 617-636.

Tsegay Moges, Rezenet. “'From White Deaf People's Adversity to Black Deaf Gain': A Proposal for a New Lens of Black Deaf Educational History." Journal Committed to Social Change on Race and Ethnicity 6, no. 1 (2020): 69-99. 
Turner, David. "Disability History and the History of Emotions: Reflections on Eighteenth-Century Britain.” Asclepio 68, no. 2 (2016): 1-13.

Ursel, Jane. Private Lives, Public Policy: 100 Years of State Intervention in the Family. Toronto: Women's Press, 1992.

Valverde, Mariana. "The Mixed Social Economy as a Canadian Tradition." Studies in Political Economy 47 (Summer 1995): 33-60.

. The Age of Light, Soap, and Water: Moral Reform in English Canada, 1885-1925. Toronto: University of Toronto Press, 2008 [1991].

Van Cleve, John Vickrey. "The Academic Integration of Deaf Children: A Historical Perspective." In The Deaf History Reader, edited by John Vickrey Van Cleve, 116-135. Washington, D.C.: Gallaudet University Press, 2007.

Van Cleve, John Vickrey and Barry Crouch. A Place of Their Own: Creating the Deaf Community in America. Washington, D.C.: Gallaudet University Press, 1989.

Vershraegen, Gert. "Historical Contingency and Human Rights Pluralism." In Debating Human Rights Inflation in Canada: A Sociology of Human Rights, edited by Dominique Clement, 133-144. Waterloo: Wilfrid Laurier University Press, 2018.

Virdi-Dhesi, Jaipreet. “Curtis' Cephaloscope: The Making of Surgical Authority in London, 1816-1845.” Bulletin of the History of Medicine 87, no. 3 (2013), 447477.

Waiser, Bill. Saskatchewan: A New History. Calgary: Fifth House, 2005.

Waldschmidt, Anne. "Disability-Culture-Society: Strengths and Weaknesses of a Cultural Model of Dis/ability." ALTER 12 (2018): 67-80.

Walsh, John C. and Steven High. "Rethinking the Concept of Community." Histoire Sociale/Social History 32, no. 64 (1999): 255-273.

Ward, Norman, and David Smith. Jimmy Gardiner: Relentless Liberal. Toronto: University of Toronto Press, 1990.

Wardclough, David. Mackenzie King and the Prairie West. Toronto: University of Toronto Press, 2000. 
Weber, Max. Economy and Society: An Outline of Interpretive Sociology. Berkeley, CA: University of California Press, 1978 [1922]).

Wesley, Jared. "Defining Prairie Politics: Campaigns, Codes, and Cultures." In Place and Replace: Essays in Western Canada, edited by Adele Perry, Esyllt W. Jones, and Leah Morton, 298-322. Winnipeg: University of Manitoba Press, 2013.

. Code Politics: Campaigns and Cultures on the Canadian Prairies. Vancouver: UBC Press, 2011.

White, Hayden. Metahistory: The Historical Imagination in Nineteenth-Century Europe. Baltimore: Johns Hopkins University Press, 1973.

White, Richard. The Middle Ground: Indians, Empires, and Republics in the Great Lakes Region, 1650-1815. New York: Cambridge University Press, 1991.

Whitmeyer, J.M. "Mann's Theory of Power - A (Sympathetic) Critique." The British Journal of Sociology 48, no. 2 (June 1997): 210-225.

Widdis, Randy William. "Crossing an Intellectual and Geographic Border: The Importance of Migration in Shaping the Canadian-American Borderlands at the Turn of the Twentieth Century." Social Science History 34, no. 4 (Winter 2010): 445-497.

Wilson, Keith. "McDermid, Duncan Wendell." Dictionary of Canadian Biography XII, 1901-1910.

Winefield, Richard. Never the Twain Shall Meet: The Communications Debate. Washington, D.C.: Gallaudet University Press, 1987.

Winzer, Margret A. The History of Special Education: From Isolation to Integration. Washington, D.C.: Gallaudet University Press, 1993.

Winzer, Margret. "Education, Urbanization, and the Deaf Community: A Case Study of Toronto, 1870-1900." In Deaf History Unveiled: Interpretations from the New Scholarship, edited by John Vickrey Van Cleve, 127-145. Washington, D.C.: Gallaudet University Press, 1993. 
Wiseman, Nelson. "The Pattern of Prairie Politics." In The Prairie West: Historical Readings, edited by R. Douglas Francis and Howard Palmer, 640-660. Edmonton: Pica Press, 1992.

Witgen, Michael. An Infinity of Nations: How the Native New World Shaped Early North America. Philadelphia: University of Pennsylvania Press, 2012.

Woloschuk, Cassandra. "Protecting and Policing Children: The Origins and Nature of Juvenile Justice in Winnipeg." In Prairie Metropolis: New Essays on Winnipeg Social History, edited by Esyllt W. Jones and Gerald Friesen, 63-81. Winnipeg: University of Manitoba Press, 2009.

Woodroofe, Kathleen. From Charity to Social Work in England and the United States. Toronto: University of Toronto Press, 1968. 


\title{
Appendix 1 - Application designed by Duncan McDermid (example from 1901)
}

\author{
Manitoba Deaf and Dumb Institution
}

Application for Admission

No.

Name:

Admitted:

As the answers to the following questions become a matter of record concerning the child, pains should be taken to give clear and definite replies to these

Questions

1. What is the full name of the applicant?

2. When and where born?

3. What is the nationality of the parents?

4. What are the full names of the father and mother?

5. What is the profession or business of the father, and is his pecuniary condition indigent, easy, or affluent?

6. Are both parents living? If not, has a second marriage occurred?

7. If the parents are deceased or fail to support the child, who is his guardian/

8. Who will take the applicant home in vacation or when requested to do so?

9. What is the post office address of parent or guardian?

10. What is the nearest railroad station and on what road is it?

11. What is the nearest telegraph office?

12. How many brothers or sisters are older than this child? How many younger?

13. Has the applicant or his parents any deaf, blind, idiotic, or insane relations? If so, specify and give particulars.

14. Was there any blood relation in parents before marriage? If so, what was the relationship?

15. What is the cause of the applicant's deafness in the opinion of the physician?

a. In the opinion of the parents?

16. At what age did the applicant become deaf?

17. If applicant was born deaf, what do parents consider as the cause?

18. Has applicant ever been under instruction? If so, where, how long, and why was instruction discontinued?

19. What sound, if any, can the applicant hear?

20. Can applicant speak any words distinctly?

21. Can applicant read words from the motion of the lips?

22. Have applicant's ears been specially treated by an aurist? If so, by whom, and with what results?

23. What useful things can the applicant do about his home?

24. Is the applicant
a. Sound in mind?
e) Free from contagious disease? 

b. In good health?
f) Troubled with nervous trembling?
c. Free from bodily deformity?
g) Addicted to the use of tobacco?
d. Free from immoral habits?
h) Subject to fits?

25. Has the applicant had scarlet fever, measles, whooping cough, mumps, or any other sickness? (State which)

26. Has the applicant had small-pox? When?

27. Has the applicant been vaccinated? When?

28. What church is preferred for the applicant to attend when the convenience of the school permits?

29. How many children have the parents had?

30. Is the applicant's father a citizen of Manitoba?

31. What is the name and address of the person who filled out this application?

After being filled out, this form of application for admission should be returned to D.W. McDermid

Institution,

Winnipeg, Man. 


\section{Appendix 2 - Application designed by Howard McDermid (example from 1917)}

The Manitoba School for the Deaf

Application for Admission

Name:

P.O. Address:

Province:

Date of Birth:

Date Admitted:

Date of application:

As the answers to the following questions become a matter of record concerning the child, pains should be taken to give clear and definite replies to these

\section{Questions}

1. What is the full name of the applicant?

2. Where was the applicant born?

3. What is the nationality of the parents?

4. What are the full names of the father and mother?

5. What is the profession or business of the father, and is his pecuniary condition indigent, easy, or affluent?

6. Are both parents living?

7. If the parents are deceased or fail to support the child, who is his guardian?

8. Who will take the applicant home in vacation or when requested to do so?

9. What is the post office address of parent or guardian?

10. What is the nearest railroad station and on what road is it?

11 . What is the nearest telegraph office?

12. How many brothers of sisters are older than this child? How many younger?

13. Has the applicant or his parents any deaf, blind, idiotic, or insane relations? If so specify and give particulars.

14. How many children have the parents had?

15. Was there any blood relations in parents before marriage? If so what was the relationship?

16. What is the cause of the applicant's deafness in the opinion of the physician?

17. In the opinion of the parents?

18. Was the child born at full term?

19. Were instruments used at delivery? 
20. Had the child a convulsion soon after birth?

21. Has the child perfect use of all its limbs? If not describe fully?

22. At what age did the applicant become deaf?

23. If the applicant was born deaf, what do parents consider as the cause?

24. Has applicant ever been under instruction? If so, where, how long, and why was instruction discontinued?

25. What sound, if any, can the applicant hear?

26. Can applicant speak any words distinctly?

27. Could the child talk more or less distinctly before deafness occurred?

28. Can applicant read words from the motion of the lips?

29. Have applicant's ears been specially treated by an aurist? If so, by whom, and with what results?

30. What useful thing can the applicant do at home?

31. Is the applicant
a) Sound in mind?
f) Free from contagious disease?
b) In good health?
g) Troubled with nervous trembling or chorea?
c) Free from bodily deformity?
h) Addicted to the use of tobacco?
d) Free from immoral habits?
i) Subject to fits?
e) Subject to rheumatism?
j) Incontinence of urine?

32. Has the applicant had scarlet fever, diphtheria, measles, whooping cough, mumps or any other sickness? (State which)

33. Has the applicant had any glandular enlargement of the neck?

34. Has applicant any catarrhal trouble?

35. Is there suppuration or running of the ears?

36. Has the applicant had smallpox? When?

37. Has the applicant been vaccinated? When?

38. Has applicant any skin disease?

39. Do certain drugs have a bad or peculiar effect upon the child? If so, name the drugs and describe the condition produced?

40. What church is preferred for the applicant to attend when the convenience of the school permits?

41. Is applicant's father a citizen of Manitoba?

42. What is the name and address of the person who filled out this application? If possible, get your family physician to assist you in these answers, After being filled out, this form of application for admission should be returned to:

$$
\begin{aligned}
& \text { H.J. McDermid, M.D. } \\
& \text { Superintendent Manitoba School for the Deaf, } \\
& \text { Winnipeg, Man. }
\end{aligned}
$$

NOTE: - Anything the parents consider important of interesting concerning heredity or habits of the applicant may be written below:

Physician's Certificate 
I hereby certify that I have examined and find that the child is in good health, entirely free from epilepsy, tuberculosis, or any other contagious or infectious disease, and is able to attend school regularly. I also believe that he (she) has a good mind and is capable of profiting by instruction, but that he (she) has not sufficient hearing to be educated in the public schools for the hearing. Therefore, I ecommend (sic) this child as a proper person to be received by and educated in the Manitoba School for the Deaf. I believe that child's deafness was caused by at the age of years.

M.D.

Date

Address 